\begin{tabular}{|lcc|}
\hline & TOTOBUANG & \\
\hline Volume 6 & Nomor 1, Juni 2018 & Halaman $1-15$ \\
\hline
\end{tabular}

\title{
REPRESENTASI KORBAN KEKERASAN DALAM TEKS BERITA DARING TRIBUN TIMUR: ANALISIS WACANA KRITIS \\ (The Representation Victims of Violence in Tribun Timur Online News Text: Critical Discourse Analysis)
}

\author{
A. Yusdianti Tenriawali \\ Universitas Iqra Buru \\ Jl. Prof. DR. H. A.R. Bassalamah, SE.,M.Si, Namlea, Kab. Buru \\ Pos-el: tenriawali@gmail.com
}

(Diterima: 29 April 2018; Direvisi: 13 Mei 2018; Disetujui: 5 Juni 2018)

\begin{abstract}
This study discussed about the representation victims of violence in the online news text of Tribun Timur online news. The purpose of this study was identifing the form of discourse strategies which was used by journalists to positioned the victims of violence in the news text on Makassar.tribunnews.com site. This research wasqualitative research by using descriptive method. this research used critical discourse analysis approach. Sources of the data in this study was taken from the text of violence news- that represented the victims of violence- which had written in the online news site Tribun Timur. The data collection in this research were using documentation and record technique. The results showed that the form of news language was the word that contained inclusive discourse strategy such asstrategy of nomination and identification. In the news texts, the nomination strategy appeared in male violance victims as natural while identification strategy appeared in women violence victims as weakness one.e. Male victims, in the online news text,tended to be more protected than female. It had indicated that Tribun Timur journalists tended to adhere the ideology of patriarchy.
\end{abstract}

Keywords: CDA, inclusive, news.

\section{Abstrak}

Penelitian ini membahas representasi korban kekerasan dalam teks berita daring Tribun Timur. Tujuan penelitian ini ialah mengidentifikasi bentuk strategi wacana yang digunakan wartawan untuk memosisikan korban kekerasan dalam teks berita pada situs Makassar.tribunnews.com. Penelitian ini merupakan penelitian kualitatif dengan menggunakan metode deskriptif. Pendekatan yang digunakan dalam penelitian ini ialah pendekatan analisis wacana kritis. Sumber data dalam penelitian ini ialah teks berita kekerasan, yang dianggap merepresentasikan korban kekerasan, dalam situs berita daring Tribun Timur. Pengumpulan data dalam penelitian ini menggunakan teknik dokumentasi dan teknik catat. Hasil penelitian menunjukkan bahwa bentuk kebahasaan berita adalah kata yang mengandung strategi wacana inklusif berupa strategi wacana nominasi dan identifikasi. Pada teks berita, strategi nominasi terlihat pada korban kekerasan laki-laki yang menampilkan korban apa adanya sedangkan strategi identifikasi lebih terlihat pada korban kekerasan perempuan sebagai pihak yang tidak berdaya. Korban laki-laki dalam teks berita daring Tribun Timur cenderung lebih dilindungi dibandingkan korban perempuan. Hal tersebut dapat diindikasikan bahwa wartawan Tribun Timur masih cenderung menganut ideologi patriarki.

Kata-kata kunci: AWK, inklusif, berita.

\section{PENDAHULUAN}

Secara faktual fenomena tindak kekerasan masih saja terjadi dalam kehidupan masyarakat, padahal apa pun ajaran agama dan kepercayaan yang ada di dunia ini tidak akan pernah memberikan legitimasi pada tindak kekerasan. Sejalan dengan dinamika perkembangan peradaban manusia yang semakin maju, seyogyanya segala bentuk tindakan kekerasan mestinya tidak perlu terjadi atau disengaja muncul (violence by design), sebab segala bentuk tindakan kekerasan tidak mencerminkan tindakan manusia yang berbudaya (Hufad, 2003:1). Bentuk tindakan kekerasan dari seseorang kepada orang lain, dari suatu kelompok kepada kelompok lainnya dengan motif apapun tergolong sebagai perilaku 
menyimpang. Hal ini tidak bisa dibenarkan menurut norma-norma sosial. Namun fenomena tindakan kekerasan yang dilakukan oleh individu, kelompok, ataupun institusi sosial hingga kini tetap saja berlangsung.

Istilah kekerasan digunakan untuk menggambarkan perilaku baik yang terbuka (overt) maupun tertutup (covert), yang bersifat menyerang (offensive) atau bertahan (defensive) yang disertai penggunaan kekuatan kepada orang lain(Suwarno, 2012:48). Ada dua hal mendasar yang perlu kita cermati ketika berbicara tentang kekerasan atau budaya kekerasan dalam masyarakat, yaitu; penggunaan kekerasan dalam masyarakat, sebagai contoh: pembunuhan atas nama Negara atau 'Tuhan atau Agama', dan legitimasi terhadap penggunaan kekerasan itu (Galtung, 2002:184).

Kekerasan fisik dan kekerasan simbolik sudah menjadi bagian kehidupan manusia. Hal tersebut terlihat pada banyaknya berita yang menunjukkan kekerasan dalam media massa, sebagai contoh pada Juni tahun 2015 muncul berita pembunuhan Engeline yang banyak menarik perhatian masyarakat. Mayat Engeline ditemukan di sekitar rumah ibu angkatnya. Berdasarkan penyelidikan polisi diketahui bahwa sebelum meninggal, Engeline mengalami penganiayaan. Berita penganiayaan yang menarik perhatian publik kembali muncul pada tahun 2016. Pada akhir tahun 2016, media massa khususnya situs berita daring kembali diramaikan dengan berita penganiayaan yang dilakukan oleh seorang pegawai Mahkamah Agung pada seorang polisi. Penganiayaan tersebut disebabkan karena pelaku penganiayaan tidak terima mobilnya yang telah melanggar jalur lalu lintas diberhentikan oleh polisi. Banyak dan beragamnya berita yang bertema kekerasan dalam media massa, menjadikan media massa sebagai salah satu sumber informasi aktual mengenai peristiwa kekerasan yang terjadi dalam masyarakat.
Salah satu wujud ketimpangan sosial yang sering menjadi sorotan di media massa dewasa ini adalah ketimpangan sosial yang menimpa para korban kekerasan pada pemberitaan di media massa. Tak jarang, media massa menyuguhkan pemberitaan yang berisi penyiksaan, pemerkosaan, pembunuhan, dan lain-lain, yang menggambarkan bahwa para korban yang mengalami kekerasan tersebut pantas mengalami kekerasan tersebut, ataupun kekerasan yang dialami para korban terjadi karena kesalahan korban sendiri.

Penggambaran media massa akan sosok korban kekerasan, khususnya pada perempuan dan anak-anak yang jika dilihat dari perspektif kesetaraan gender, telah terjadi praktik diskriminasi yang dilakukan oleh media massa. Perempuan dan anakanak sebagai sosok yang dianggap lemah, dicitrakan pantas atau sudah biasa menjadi korban kekerasan, sehingga pelaku yang melakukan tindak kekerasan pada perempuan dan anak-anak dianggap wajar jika melakukan tindak kekerasan tersebut.

Namun, realita saat ini, yang menjadi korban kekerasan bukan hanya perempuan dan anak-anak, tetapi laki-laki pun telah menjadi korban kekerasan. Banyaknya berita dalam media massa yang memberitakan tentang laki-laki yang menjadi korban kekerasan, menjadi bukti bahwa korban kekerasan tidak hanya terjadi pada perempuan dan anak-anak, tetapi terjadi juga pada laki-laki. Fenomena tersebut menjadi menarik, sebab bagaimana cara media massa menggambarkan sosok laki-laki yang menjadi korban kekerasan kemungkinan besar akan berbeda dengan cara media massa menggambarkan korban kekerasan yang dialami perempuan dan anak-anak.

Hal tersebut didasari pandangan umum bahwa laki-laki tidak mungkin menjadi korban sebab laki-laki dianggap memiliki kekuatan, sedangkan perempuan dan anak-anak yang dianggap lemah sehingga wajar menjadi korban. Bagaimana media massa menggambarkan atau 
merepresentasikan korban kekerasan dalam berita pada berita. Bagaimana cara media massa, khususnya dalam situs berita daring koran Tribun Timur merepresentasikan korban kekerasan yang dialami oleh perempuan dan laki-laki, apakah terdapat perbedaan representasi jika korban kekerasan tersebut perempuan atau laki-laki merupakan fokus penelitian ini.

Untuk melihat bagaimana representasi korban kekerasan pada situs berita daring Tribun Timur, maka peneliti menggunakan analisis wacana kritis dengan model Theo Van Leeuwen. Analisis wacana kritis dengan model Theo Van Leeuwen yang digunakan dalam penelitian ini merupakan model yang telah dikembangkan oleh Eriyanto.

Penelitian mengenai representasi korban kekerasan telah banyak dilakukan, diantaranya Suganda, dkk. (2007:5) yang menunjukkan bahwa media massa nasional merepresentasikan sosok Tenaga Kerja Wanita Indonesia sebagai sosok yang marginal, tidak mempunyai kekuatan dan kekuasaan, kampungan, tak berpendidikan, miskin, bodoh, dan lain-lain. Setiawan (2011:14) yang meneliti pemberitaan kekerasan berbasis gender di surat kabar harian suara merdeka menyimpulkan bahwa surat kabar Harian Suara Merdeka telah secara tidak adil menginformasikan berita kekerasan terhadap perempuan dengan menempatkan perempuan sebagai objek penderita. Hasanah (2013:159) yang meneliti kekerasan terhadap perempuan dan anak dalam rumah tangga perspektif pemberitaan media menunjukkan bahwa opini dan peran media dirasa cukup besar dalam mengonstruksi realitas secara sosial.

Juditha (2015:15) meneliti tentang Dilematis Media dalam Pemberitaan Konflik dan Kekerasan. Hasil penelitian menunjukkan bahwa Media massa dinilai memiliki potensi fungsional karena berpotensi untuk menebar semangat perdamaian dan meredakan konflik. Sebaliknya media massa juga dinilai memiliki potensi untuk memperkeruh atau bahkan memicu konflik yang berkepanjangan. Serta Fauziah \& Tamampil (2015:131) yang meneliti tentang representasi perempuan dalam pemberitaan KDRT di media massa pada masyarakat di wilayah jakarta. Dari hasil penelitian dapat disimpulkan bahwa dalam berita yang terkait dengan KDRT merepresentasikan perempuan (istri) sebagai objek. Teks berita tersebut menjadi bias dalam merepresentasikan perempuan karena dalam teks berita tersebut suara perempuan (istri) tidak benar-benar ditunjukkan.

Dari berbagai penelitian di atas, terlihat bahwa yang menjadi fokus penelitian pada hampir semua penelitian terdahulu korban perempuan. Mengingat bahwa yang menjadi korban kekerasan tidak hanya perempuan namun juga laki-laki, maka penelitian ini akan melihat bagaimana representasi laki-laki dan perempuan sebagai korban kekerasan dalam situs berita daring Tribun Timur.

Berdasarkan latar belakang tersebut, pokok permasalahan dalam penelitian ini adalah Bagaimanakah bentuk strategi wacana berita yang digunakan dalam merepresentasikan korban kekerasan pada situs makassar.tribunnews.com? tujuan penelitian ini untuk mengidentifikasi bentuk kebahasaan strategi wacana yang digunakan wartawan dalam memosisikan korban kekerasan dalam teks berita pada situs makassar.tribunnews.com.

Melalui penelitian ini, peneliti berupaya melengkapi berbagai penelitian tentang korban kekerasan di media massa yang telah dilakukan peneliti sebelumnya dengan memasukkan korban laki-laki sebagai objek penelitian tindak kekerasan. Penelitian ini belum mencakup analisis tentang efek teks berita yang ditimbulkan atau dihasilkan dalam masyarakat.

\section{LANDASAN TEORI}

Hall (2003:17) mendefiniskan 'representasi' sebagai “...an essential part of the process by which meaning is produced and exchanged between members of culture". 
Representasi merupakan salah satu bagian terpenting dalam proses produksi makna. Suatu makna diproduksi dan dipertukarkan antar anggota masyarakat, sehingga representasi merupakan suatu cara untuk memproduksi makna.

Istilah representasi dalam konteks pemberitaan merujuk pada bagaimana seseorang, suatu kelompok, gagasan atau pendapat tertentu ditampilkan (Eriyanto, 2001:22). Hal yang perlu diperhatikan menyangkut hal representasi, yaitu apakah seseorang, kelompok, atau gagasan tersebut ditampilkan sebagaimana mestinya. Apakah seseorang atau kelompok tersebut diberitakan apa adanya, ataukah diburukkan. Bagaimana representasi tersebut ditampilkan. Kata, kalimat, tanda apa saja yang digunakan untuk melakukan representasi tentang sesuatu. Hal tersebut sesuai dengan pendapat Van Leeuwen (2008:28) "representations include or exclude social actors to suit their interests and purposes in relation to the readers for whom they are intended". Setiap pernyataan dalam teks berita merupakan pilihan seorang wartawan berdasarkan tujuan yang diinginkannya.

Model analisis wacana yang digunakan dalam penelitian ini adalah model analisis Theo Van Leuween. Model analisis ini digunakan untuk mendeteksi dan meneliti bagaimana suatu kelompok atau seseorang dimarginalkan posisinya dalam suatu wacana. Pemarginalan ini dapat dilihat dari dihadirkan (inklusi) atau dikeluarkannya (eksklusi) suatu kelompok atau seseorang ini dalam teks (Eriyanto, 2003:171).

Eksklusi adalah suatu isu sentral dalam analisis wacana. Pada dasarnya eksklusi adalah proses bagaimana satu kelompok atau aktor sosial tertentu tidak dilibatkan dalam suatu proses pembicaraan atau wacana. Penghilangan aktor sosial ini memiliki tujuan tertentu. Menurut Van Leuween pembaca berita perlu mengkritisi bagaimana tiap-tiap kelompok itu ditampilkan dalam teks, apakah ada pihak atau aktor yang dengan strategi wacana tertentu hilang dalam teks atau tidak (Eriyanto, 2003:173). Proses eksklusi terbagi atas pasifasi, nominalisasi, dan penggantian anak kalimat.

Pasifasi merupakan Salah satu cara klasik penghilangan tokoh dalam sebuah wacana adalah melalui membentuk kalimat pasif. Lewat pemakaian kalimat pasif, aktor tidak dapat hadir dalam teks, sesuatu yang tidak mungkin terjadi dalam kalimat. yang berstruktur aktif (Eriyanto, 2003:173). Contoh:

\begin{tabular}{|l|ll|}
\hline Aktif & $\begin{array}{l}\text { Polisi menembak mahasiswa yang } \\
\text { berdemonstrasi hingga tewas. }\end{array}$ \\
\hline Pasif & $\begin{array}{l}\text { Seorang mahasiswa tertembak saat } \\
\text { demonstrasi. }\end{array}$ \\
\hline
\end{tabular}

Strategi wacana nominalisasiadalah strategi yang sering digunakan untuk menghilangkan kelompok atau aktor sosial tertentu dalam wacana. Strategi ini berhubungan dengan mengubah kata kerja menjadi kata benda (Eriyanto, 2003:174).

Contoh:

\begin{tabular}{|l|l|}
\hline Verba & $\begin{array}{l}\text { Polisi menembak seorang } \\
\text { mahasiswa yang } \\
\text { berdemonstasi hingga tewas. }\end{array}$ \\
\hline Nominalisasi & $\begin{array}{l}\text { Seorang mahasiswa tewas } \\
\text { akibat penembakan saat } \\
\text { demonstrasi. }\end{array}$ \\
\hline
\end{tabular}

Penggantian subjek juga dapat dilakukan dengan membangun anak kalimat yang sekaligus berfungsi sebagai pengganti aktor (Eriyanto, 2003:178).

Contoh:

\begin{tabular}{|l|lr|}
\hline $\begin{array}{l}\text { Tanpa } \\
\text { Anak } \\
\text { Kal }\end{array}$ & $\begin{array}{l}\text { Polisi menembak } \\
\text { mahasiswa hingga tewas. }\end{array}$ \\
\hline $\begin{array}{l}\text { Dengan } \\
\text { Anak }\end{array}$ & $\begin{array}{l}\text { Untuk mengendalikan } \\
\text { Kahasiswa, temonstrasi }\end{array}$ \\
Kal & $\begin{array}{l}\text { Akibatnya seorang } \\
\text { tewas. }\end{array}$ & mahasiswana \\
\end{tabular}

Inklusi merupakan strategi wacana yang dapat digunakan jika menginginkan sesuatu, seseorang, atau kelompok ditampilkan dalam teks. Proses inklusi 
terbagi menjadi diferensiasi dan indeferensiasi, objektivasi dan abstraksi, nominalisasi dan kategorisasi, nominalisasi dan identifikasi, determinasi dan indeterminasi, asimilasi, dan individualisasi, serta asosiasi dan disasosiasi.

Diferensiasi dan indeferensiasi merupakan strategi wacana untuk menampilkan suatu kelompok yang disudutkan dengan menghadirkan kelompok atau wacana lain yang dipandang lebih dominan atau lebih bagus.

Contoh:

\begin{tabular}{|l|l|}
\hline Indiferensiasi & $\begin{array}{l}\text { Buruh pabrik Maspion } \\
\text { sampai kemarin masih } \\
\text { melanjutkan mogok. }\end{array}$ \\
\hline Diferensiasi & $\begin{array}{l}\text { Buruh pabrik Maspion } \\
\text { sampai kemarin masih } \\
\text { melanjutkan mogok. } \\
\text { Sementara tawaran direksi } \\
\\
\\
\text { yang menawarkan } \\
\text { perundingan tidak } \\
\text { ditanggapi buruh. }\end{array}$ \\
\hline
\end{tabular}

Objektivasi dan abstraksi merupakan strategi wacana yang berhubungan dengan pertanyaan apakah informasi mengenai suatu peristiwa atau aktor sosial ditampilkan dengan memberi petunjuk konkret ataukah yang ditampilkan adalah abstraksi (Eriyanto, 2003:181).

Contoh:

\begin{tabular}{|l|l|}
\hline Objektivasi & $\begin{array}{l}\text { PKI telah dua kali melakukan } \\
\text { pemberontakan }\end{array}$ \\
\hline Abstraksi & $\begin{array}{l}\text { PKI telah berulang-ulang } \\
\text { melakukan pemberontakan. }\end{array}$ \\
\hline
\end{tabular}

Dalam suatu pemberitaan yang menggunakan strategi nominalisasi dan kategorisasi, aktor sosial seringkali dimunculkan dengan kategori yang dimilikinya. Kategori ini bermacam-macam, misalnya menunjukkan ciri penting dari seseorang: bisa agama, status, bentuk fisik, dan sebagainya (Eriyanto, 2003:182). Contoh:

\begin{tabular}{|l|l|l|}
\hline Nominalisasi & $\begin{array}{l}\text { Seorang } \\
\text { wanita }\end{array}$ & $\begin{array}{l}\text { ditemukan } \\
\text { tewas, diduga } \\
\text { sebelumnya } \\
\text { diperkosa }\end{array}$ \\
\hline
\end{tabular}

\begin{tabular}{|l|l|l|}
\hline Kategorisasi & $\begin{array}{l}\text { Seorang } \\
\text { wanita tak } \\
\text { dikenal }\end{array}$ & $\begin{array}{l}\text { ditemukan } \\
\text { tewas, diduga } \\
\text { sebelumnya } \\
\text { diperkosa }\end{array}$ \\
\cline { 2 - 3 } & $\begin{array}{l}\text { Seorang } \\
\text { wanita } \\
\text { muda }\end{array}$ & $\begin{array}{l}\text { ditemukan } \\
\text { tewas, diduga } \\
\text { sebelumnya } \\
\text { diperkosa }\end{array}$ \\
\cline { 2 - 3 } & $\begin{array}{l}\text { Seorang } \\
\text { wanita } \\
\text { malam }\end{array}$ & $\begin{array}{l}\text { ditemukan } \\
\text { tewas, diduga } \\
\text { sebelumnya } \\
\text { diperkosa }\end{array}$ \\
\cline { 2 - 3 } & $\begin{array}{l}\text { Seorang } \\
\text { janda }\end{array}$ & $\begin{array}{l}\text { ditemukan } \\
\text { tewas, diduga } \\
\text { sebelumnya } \\
\text { diperkosa }\end{array}$ \\
\hline
\end{tabular}

Strategi wacana nominalisasiidentifikasi hampir mirip dengan ketegorisasi, yaitu bagaimana suatu kelompok, peristiwa, atau tindakan tertentu didefinisikan. Bedanya, dalam strategi indentifikasi, proses pendefinisian itu dilakukan dengan memberi anak kalimat sebagai penjelas. Bentuk konstruksi pemberitaan dalam identifikasi terdiri atas ada dua proposisi, dalam hal ini proposisi kedua adalah penjelas atau keterangan dari proposisi pertama. Umumnya bentuk identifikasi dihubungkan dengan kata hubung sepertiyang, di mana (Eriyanto, 2003:184).

Contoh:

\begin{tabular}{|l|l|}
\hline Nominalisasi & $\begin{array}{l}\text { Seorang wanita tewas, diduga } \\
\text { sebelumnya diperkosa. }\end{array}$ \\
\hline Identifikasi & $\begin{array}{l}\text { Seorang wanita, yang sering } \\
\text { keluar malam, ditemukan } \\
\text { tewas. Diduga sebelumnya } \\
\text { diperkosa. }\end{array}$ \\
\hline
\end{tabular}

Strategi determinasi-indeterminasi seringkali menampilkan atau menyebutkan aktor atau peritiwa secara jelas, namun sering kali juga disebutkan secara tidak jelas (anonim). Anonimitas ini bisa jadi karena wartawan belum mendapatkan bukti yang cukup untuk menulis atau akibat ketakutan struktural jika mengungkapkan aktor sosial itu dalam teks. Menurut Van Leuween, anonimitas justru membuat suatu 
generalisasi menjadi tidak spesifik (Eriyanto, 2003:186).

Contoh:

\begin{tabular}{|l|l|}
\hline Determinasi & $\begin{array}{l}\text { Menlu Alwi Shihab disebut- } \\
\text { sebut terlibat skandal bulog. }\end{array}$ \\
\hline Indeterminasi & $\begin{array}{l}\text { Orang dekat Gus Dur } \\
\text { disebut-sebut terlibat dalam } \\
\text { skandal Bulog. }\end{array}$ \\
\hline
\end{tabular}

Strategi wacana individualisasiasimilasi berhubungan dengan pertanyaan apakah aktor sosial yang diberitakan ditunjukkan dengan jelas ketegorinya atau tidak. Asimilasi terjadi apabila dalam pemberitaan, bukan ketegori sosial yang spesifik yang disebut dalam berita, melainkan komunitas atau kelompok sosial dimana seseorang tersebut berada (Eriyanto, 2003:190).

Contoh:

\begin{tabular}{|l|lr|}
\hline Individualisasi & $\begin{array}{l}\text { Adi, } \\
\text { seorangmahasiswaTrisakti, } \\
\text { tewas ditembak ranan, } \\
\text { seorang polisi dalam } \\
\text { demonstrasi di Cendana } \\
\text { kemarin. }\end{array}$ \\
\hline Asimilasi & $\begin{array}{l}\text { Mahasiswa tewas ditembak } \\
\text { polisi dalam demonstasi di } \\
\text { Cendana kemarin. }\end{array}$ \\
\hline
\end{tabular}

Strategi wacana asosiasi-disasosiasi berhubungan dengan pertanyaan apakah aktor suatu pihak ditampilkan sendiri ataukah dihubungkan dengan kelompok lain yang lebih besar. Dalam sebuah teks, asosiasi berkaitan dengan aktor sosial yang dihubungkan dengan kelompok yang lebih besar, atau tempat aktor itu berada. Sebaliknya, disasosiasi berkaitan dengan aktor sosial dalam suatu teks yang tidak dihubungkan dengan kelompok yang lebih besar (Eriyanto, 2003:194).

Contoh:

\begin{tabular}{|c|c|}
\hline Asosiasi & $\begin{array}{lr}\text { Umat Islam di mana-mana } \\
\text { selalu menjadi } & \text { sasaran } \\
\text { pembantaian. Setelah } & \text { Bosnia, } \\
\text { sekarang Ambon. Sebanyak } 40 \\
\text { orang meninggal dalam kasus } \\
\text { Tobelo, Galela, dan Jailolo. }\end{array}$ \\
\hline
\end{tabular}

\begin{tabular}{|l|l|}
\hline Disasosiasi & $\begin{array}{l}\text { Sebanyak 40 orang muslim } \\
\text { meninggal dalam kasus Tobelo, } \\
\text { Galela, dan Jailolo. }\end{array}$ \\
\hline
\end{tabular}

\section{METODE}

Penelitian ini merupakan penelitian kualitatif dengan menggunakan metode deskriptif.Pendekatan yang digunakan dalam penelitian ini adalah pendekatan analisis wacana kritis. Penelitian kualitatif dengan metode deskriptif adalah penelitian yang mengidentifikasi, mengklarifikasi, menganalisis data yang telah diperoleh. Pendeskripsiannya berupa penggambaran bahasa sebagaimana adanya (Sudaryanto, 1993:62). Dengan demikian, data dalam penelitian ini berupa teks berita, akan diidentifikasi, diklasifikasikan, dan dianalisis berdasarkan teori strategi wacana Van Leuween untuk menngetahui representasi korban kekerasan pada situs berita daring Tribun Timur.

Sumber data penelitian ini adalah situs berita daring makassar.tribunnews.com., sedangkan jenis data dalam penelitian ini adalah data tertulis, yaitu teks berita yang merepresentasikan tindak kekerasan yang dimuat pada situs berita daring Tribun Timur pada Oktober, tahun 2016.Metode pengumpulan data pada penelitian ini adalah metode simak. Teks dalam berita pada situs berita daring Tribun Timur disimak. Teks yang disimak tersebut dikhususkan pada teks yang merepresentasikan tindak kekerasan, kemudian ditandai, serta didokumentasikan untuk diinventarisasikan sebagai data dalam penelitian ini.

Analisis data dalam penelitian ini terdiri atas; identifikasi data, klasifikasi data, analisis data, dan penyimpulan hasil analisis data. Data yang telah dianalisis selanjutnya diinterpretasikan dan dijelaskan bentuk dan makna teks berita yang merepresentasikan korban kekerasan pada situs berita daring Tribun Timur sehingga pada akhirnya terungkap perepresentasian korban kekerasan dalam teks berita. 


\section{PEMBAHASAN}

Berdasarkan hasil analisis data yang telah dilakukan. Bentuk strategi wacana yang digunakan adalah strategi nominalisasi dan identifikasi. Kecenderungan penggunaan strategi nominalisasi dan identifikasi menjadi ciri khas teks berita yang merepresentasikan korban kekerasan dalam situs Makassar.tribunnews.com.

Secara umum bahasa yang digunakan dalam surat kabar daring Tribun Timur cenderung netral dan merekam realitas yang terjadi dengan apa adanya. Hal tersebut dibuktikan dengan penggunaan strategi wacana nominalisasi. Strategi wacana nominalisasi adalah strategi wacana yang digunakan wartawan untuk menggambarkan aktor sosial dengan apa adanya tanpa menunjukkan ciri tertentu yang melekat pada aktor sosial tersebut, misalnya status sosial atau ciri fisik. Ditemukannya data strategi wacana nominalisasi menunjukkan bahwa bahasa yang digunakan wartawan Tribun Timur dalam memberitakan korban kekerasan cenderung apa adanya. Berikut hasil analisis data strategi wacana dalam teks berita daring Tribun Timur.

\section{Teks berita 1}

Pukul Wartawan, Oknum Pengacara Kasus Calo Polisi Dilapor Ke Polres Jeneponto

Kamis, 13 Oktober 2016 20:38

TRIBUNJENEPONTO.COM, BINAMU Kontributor Metro TV Jeneponto, Sulaiman Nai melaporkan dugaan penganiayaan yang dilakukan Upa Labuhari yang mengaku wartawan dari Jakarta.

Penganiayaan terjadi saat Sulaiman Nai bersama awak media lainnya mencoba mewawancarai Upa Labuhari yang telah menjalani pemeriksaan di Satreskrim Polres Jeneponto.

"Kejadiannya waktu kita coba wawancara duagaan kasus penipuan, namun waktu diliput dia marah-marah dan sedikit arogan," ujar Sulaiman Nai.
Pelaku yang tidak terima disorot kamera, langsung melakukan pemukulan terhadap Sulaiman dengan menggunakan botol mineral.

Akibatnya, Sulaiman pun mengalami luka merah pada perut dan kameranya basah terkena cipratan air.

"Ini merah perutku dipukul pakai botol dan basahki juga kameraku," ujar Sulaiman yang diintrogasi penyidik Reskrim Polres Jeneponto.

Sulaiman pun berharap agar oknum yang mengaku wartawan sekaligus pengacara terduga kasus calo polisi di Polres Jeneponto segera diamankan.

"Saya harap Polres tindak tegas pelaku tersebut karena telah mencoreng kerja Jurnalis yang juga dilindungin dengan undang - undang, "tuturnya.

Strategi wacana yang digunakan dalam judul teks berita 'Pukul Wartawan, Oknum Pengacara Kasus Calo Polisi Dilapor Ke Polres Jeneponto' adalah strategi wacana nominalisasi. Aktor sosial baik korban maupun pelaku pemukulan ditampilkan apa adanya dalam teks. Strategi nominalisasi yang digunakan wartawan Tribun Timur dalam judul teks berita berfungsi untuk memberitahukan informasi tentang peristiwa pemukulan.

Pada bagian isi teks berita 1 , strategi wacana yang digunakan adalah strategi identifikasi yang terdapat dalam kalimat berikut:

1) "Kejadiannya waktu kita coba wawancara duagaan kasus penipuan, namun waktu diliput dia marah -marah dan sedikit arogan," ujar Sulaiman Nai.

2) Pelaku yang tidak terima di sorot kamera, langsung melakukan pemukulan terhadap Sulaiman dengan menggunakan botol mineral.

Kata marah-marah dan arogan pada kalimat 1, serta frasa tidak terima pada kalimat 2 menunjukkan identifikasi yang menunjukkan bahwa perilaku pelaku pemukulan bersifat kasar (karena marahmarah) dan angkuh (arogan dan tidak terima 
disorot kamera). Penggunaan strategi identifikasi pada isi teks berita tidak hanya bermaksud untuk menunjukkan informasi mengenai peristiwa pemukulan dan juga bermaksud untuk memengaruhi pendapat pembaca tentang perilaku pelaku.

\section{Teks berita 2}

Sadis, Syamsuddin Tega Gorok Leher Upa Hingga Meninggal di Tolo Timur Jeneponto

Minggu, 16 Oktober 2016 09:26

TRIBUNJENEPONTO.COM, BINAMU Upa (35) warga Sapaloe, Kelurahan Tolo Timur, Kecamatan Kelara, Kabupaten Jeneponto, menjadi korban pembunuhan, Sabtu (15/10/2016) malam.

Upa diduga dibunuh warga sekampungnya sendiri, Syamsuddin (35).

Syamsuddin tega menghabisi nyawa Upa secara sadis.

Degan menggunakan senjata tajam jenis parang, Syamsuddin menggorok leher dan sejumlah bagian tubuh korban.

Akibatnya, korban pun meninggal dunia dengan beberapa luka di bagian tubuhnya.

Mulai dari pergelangan tangan perut hingga leher terdapat luka menganga bekas sabetan senjata tajam.

Dugaan sementara, motif pembunuhan karena kesalahpahaman.

Korban Upun saat ini telah disemayamkan di rumah duka.

Sementara pelaku Syamsuddin beserta barang bukti yang diduga alat yang digunakan membunuh, telah diamankan di Mapolres Jeneponto, Jl Pelita, Kecamatan Binamu, Kabupaten Jeneponto.

Strategi wacana yang digunakan dalam judul teks berita 'Sadis, Syamsuddin Tega Gorok Leher Upa Hingga Meninggal di Tolo Timur Jeneponto' adalah strategi identifikasi. Strategi identifikasi dalam judul teks ditandai dengan penggunaan kata sadis untuk menunjukkan perbuatan pelaku. Pada judul teks, wartawan Tribun Timur menunjukkan bahwa perbuatan pelaku terhadap korban adalah perbuatan yang sadis.

Pada bagian isi berita, strategi wacana yang digunakan adalah strategi identifikasi. Strategi identifikasi tersebut terlihat dalam kalimat berikut:

1) Upa diduga dibunuh warga sekampungnya sendiri, Syamsuddin (35).

2) Syamsuddin tega menghabisi nyawa Upa secara sadis.

3) Dugaan sementara, motif pembunuhan karena kesalahpahaman.

Pada Kalimat 1, penggunaan frasa warga sekampung memberikan identifikasi bahwa yang membunuh korban adalah warga sekampungnya sendiri atau orang dekat korban. Pada kalimat 2, penggunaan kata sadis mengidentifikasi bahwa tindakan pelaku tersebut merupakan tindakan sadis. Pada kalimat 3, penggunaan kata kesalahapahaman mengidentifikasi motif atau alasan terjadinya peristiwa pembunuhan. Strategi identifikasi pada kalimat 1, 2, dan 3 di atas berfungsi untuk menunjukkan bahwa pelaku merupakan orang sadis yang tega membunuh tetangganya sendiri hanya karena salah paham.

\section{Teks berita 3}

Suryana Diseret Pembegal Sejauh Lima Meter di BTP

Selasa, 11 Oktober 2016 21:34

Laporan Wartawan Tribun Timur, Darul Amri

TRIBUN-TIMUR.COM, MAKASSAR Suryana Anas, wartawati Tribun Timur terseret lima meter dari motornya saat dibegal di Jl Keberkahan, Bumi Tamalanrea Permai, Kecamatan Biringkanaya, Selasa (11/10/2016) dini hari.

Suryana mengatakan, saat kejadian, ada dua pelaku yang menggunakan sepeda motor yang memepet motornya dan meminta dompetnya. 
"Ada dua orang, jadi yang di belakang itu suruh serahkan dompet tapi saya teriak minta tolong. Tapi pelaku langsung menarik tas saya dan saya terseret," katanya.

Tas selempang yang terkait dilehernya pun ditarik pelaku. Korban terhempas dari motornya dan pelaku yang masih sementara mengendarai motor menyeret korban hingga sejauh lima meter.

Surayna mengaku, tidak alami kerugian pada barang bawaannya. Namun wajah bagian kanan atas mengalami bengkak akibat tonjok dari salah satu pelaku.

Selain itu, luka gores pada bagian bawah mata kanan, bibirnya juga alami memar dan bagian badan sebelah kanan mengalami memar akibat diseret.

"Jadi pelaku juga memukul wajah saya sampai saya terjatuh dan lalu diseret, jilbab saya juga sobek," jelas Suryana yang hingga kini masih terbaring di UGD RS Wahidin Sudirohusodo.

Secara terpisah, Kapolsek Biringkanaya Kompol Dodik mengatakan, pihaknya akan secepatnya mengungkap pelaku yang telah melakukan pencurian dan kekerasan (Curas) atau begal.

"Yang jelas kami akan ungkap karena yang menyaksikan hanya korban sendiri untuk itu kita akan dalami semua ciri-ciri pelaku menurut korban," katanya.

Dodik juga berharap ada kerjasama antara korban, polisi dan masyarakat itu yang sangat diperlukan dalam ungkap semua permasalahan.

"Tentunya kerjasama itu bisa ungkap siapa pelakunya pada umumnya terkait masalah begal dilingkungan dan wilayah hukum polsek kami," lanjutnya. $\left({ }^{*}\right)$

Strategi wacana yang digunakan dalam judul teks berita 'Suryana Diseret Pembegal Sejauh Lima Meter di BTP' adalah strategi wacana nominalisasi. Pada teks judul, korban diberitakan terseret pembegal sejauh lima meter di BTP. Strategi nominalisasi dalam judul teks berita menginformasikan peristiwa yang dialami korban dengan apa adanya.

Pada bagian isi berita, strategi wacana yang digunakan adalah strategi wacana nominalisasi. Hal tersebut terlihat dalam kalimat berikut:

1) Suryana mengatakan, saat kejadian, ada dua pelaku yang menggunakan sepeda motor yang memepet motornya dan meminta dompetnya.

2) Korban terhempas dari motornya dan pelaku yang masih sementara mengendarai motor menyeret korban hingga sejauh lima meter.

Kata pelaku dan memepet pada kalimat 1 serta kata pelaku dan menyeret pada kalimat 2, menunjukkan peristiwa yang dialami korban. Pelaku yang berjumlah dua orang memepet dan menarik tas korban sehingga korban akhirnya terseret sejauh lima meter. Strategi nominalisasi pada kedua kalimat di atas menunjukkan informasi tentang peristiwa yang dialami korban.

\section{Teks berita 4}

Warga Mengaku Dipukul Polisi, Kapolsek Belawa: Dia Meresahkan

Kamis, 6 Oktober 2016 22:42 TRIBUNWAJO.COM, BELAWA - Kapolsek Belawa, AKP Andi Bangsawan membantah melakukan pemukulan terhadap Supriadi, warga Desa Leppangeng, Kecamatan Belawa, Wajo. $\mathrm{Hal}$ itu disampaikan AKP Andi Bangsawan kepada tribunwajo.com

"Lelaki Supriadi alias Cupli ini sangat meresahkan masyarakat Belawa dengan sering melempar anggota polsek yang sedang berada di halaman Polsek Belawa dan rumah warga setempat Ramli," ujar AKP Andi Bangsawan.

"Begitupula melempari pejalan kaki yang sedang melintas dijalan saat itu," sambungnya kepada tribunwajo.com

Beberapa korbannya pada saat itu lanjut Kapolsek yakni, anggota Polsek Belawa, warga setempat, Ramli, dan 
Totobuang, Vol. 6, No. 1, Juni 2018: 1-15

pejalan kaki, Ancu dan Caddi, (3/10/2016).

AKP Andi Bangsawan juga menambahkan pelaku diamankan karena permintaan kedua orang tuanya.

"Atas permintaan keluarganya Jumadi dan Imani datang di Polsek Belawa meminta bantuan untuk menangkap Supriadi, jadi Upaya yang saya lakukan bersama 3 orang anggota datang ke rumah pelaku,"

"Namun saat itu Supriadi melakukan perlawanan memegang Batu dan kayu, tetapi 2 orang anggota memegang tangannya dan 1 orang anggota memegang kakinya, kemudian saya mengikat tangan dan kakinya dengan tali karena memberontak terus dan mengangkat masuk dirumah untuk menyerahkan sama keluarganya," lanjutnya.

Akibat ulah Supriadi tersebut, la diduga mengalami gangguan jiwa.

"Pada saat itu disampaikan pada orang tuanya dan keluarganya agar dibawa untuk berobat, namun orang tuanya tidak ada upaya dibawa berobat anaknya," tutupnya.

Sebelumnya, Supriadi(28) Warga Desa Lappangeng Kecamatan Belawa Kabupaten Wajo mengaku dianiaya oleh oknum polisi di daerahnya.

Hal tersebut diungkapkan SP saat menceritakan kasus yang dialaminya saat melapor di kantor Lembaga Bantuan Hukum (LBH) Makassar Jl Pelita Raya kota Makassar, Kamis (6/10/2016).

"Waktu itu kapolsek yang ikat saya, tiga anggotanya datang langsung pukul saya di bagian telinga, dada dan di bagian wajah," cerita Supriadi didepan staf $L B H$ dan beberapa wartawan.

Strategi wacana yang digunakan dalam judul teks berita 'Warga Mengaku Dipukul Polisi, Kapolsek Belawa: Dia Meresahkan' adalah strategi identifikasi. Korban yang mengaku telah dipukul polisi, diidentifikasi oleh polisi sebagai orang yang meresahkan. Identifikasi sebagai orang yang meresahkan tersebut menjadikan posisi korban dalam judul teks berita termarginalkan.

$$
\text { Pada bagian isi berita, strategi }
$$
wacana yang digunakan adalah strategi wacana identifikasi. Strategi identifikasi dalam isi teks berita terdapat dalam kalimat berikut:

1) Lelaki Supriadi alias Cupli ini sangat meresahkan masyarakat Belawa dengan sering melempar anggota polsek yang sedang berada di halaman Polsek Belawa dan rumah warga setempat Ramli.

2) Beberapa korbannya pada saat itu lanjut Kapolsek yaitu, anggota Polsek Belawa, warga setempat, Ramli, dan pejalan kaki, Ancu dan Caddi.

3) "Atas permintaan keluarganya Jumadi dan Imani datang di Polsek Belawa meminta bantuan untuk menangkap Supriadi, jadi Upaya yang saya lakukan bersama 3 orang anggota datang ke rumah pelaku".

Frasa sangat meresahkan, sering melempar pada kalimat 1, kata korbannya pada kalimat 2, serta kata permintaan keluarga dan menangkap pada kalimat 3, menunjukkan identifikasi terhadap perilaku korban yang meresahkan. Korban (Supriadi) dianggap meresahkan karena sering melempari aparat dan warga setempat yang mengakibatkan keluarganya meminta kepada polisi agar korban ditangkap. Identifikasi tentang perilaku korban yang meresahkan pada kalimat 1 menunjukkan bahwa korban dimarginalkan dalam teks berita.

\section{Teks berita 5}

Wartawan Media Online di Gowa jadi Korban Pengeroyokan Debt Collector

Rabu, 5 Oktober 2016 18:45

Laporan Wartawan Tribun Timur Wa Ode Nurmin

TRIBUN-TIMUR.COM, SUNGGUMINASA- Wartawan media online di Gowa, Muhammad Dahlan (23), 
menjadi korban pengeroyokan dari beberapa pria yang diketahui debt Collector di depan kantornya, Jl. Tumanurung, Rabu (5/10).

Dari keterangan Dahlan saat melaporkan kejadian itu di Mapolres Gowa, dia dikeroyok Collector dari pembiayaan motor Bank Sampoerna yang beralamat di Jl Veteran Selatan, Makassar.

"Memang motor ku menunggak satu bulan, tapi saya bilang saya bayar besok. Saya juga siap tulis pernyataan. Tidak mau juga, dia paksa tarik dan ambil itu motor, " katanya.

Saat Dahlan mencoba mempertahankan motor itu, para pria yang berjumlah lima orang tersebut langsung memukul dan menginjak tangan dan menendang kakinya.

Akhirnya motor Yamaha Hino yang baru dua bulan dia kredit itu disita. Namun Dahlan meyayangkan sebab ada kamera yang dia simpan di sadel motor.

Sementara itu Kanit, Ipda Marsuni Ago mengatakan, saat ini korban sudah dimintai keterangannya di SPKT.

"Dari keterangan korban awalnya satu orang yang datang menanyakan identitasnya, setelah itu beberapa lagi datang sambil membawa mobil pickup. Yang pasti Kita sudah terima keterangannya, "katanya lagi.(*)

Pada judul teks berita 'Wartawan Media Online di Gowa jadi Korban Pengeroyokan Debt Collector' strategi wacana yang digunakan adalah strategi nominalisasi. Strategi nominalisasi dalam judul teks berita ditandai dengan pemberitaan tentang peristiwa pengeroyokan dengan menampilkan korban apa adanya.

Pada bagian isi berita, strategi wacana yang digunakan adalah strategi identifikasi. Strategi identifikasi dalam teks terdapat dalam kalimat berikut:

1) Dari keterangan Dahlan saat melaporkan kejadian itu di Mapolres Gowa, dia dikeroyok Collector dari pembiayaan motor Bank Sampoerna yang beralamat di Jl Veteran Selatan, Makassar.

2) "Memang motor ku menunggak satu bulan, tapi saya bilang saya bayar besok. Saya juga siap tulis pernyataan. Tidak mau juga, dia paksa tarik dan ambil itu motor".

3) Saat Dahlan mencoba mempertahankan motor itu, para pria yang berjumlah lima orang tersebut langsung memukul dan menginjak tangan dan menendang kakinya.

Kata dikeroyok, collector pada kalimat 1, kata menunggak, siap tulis penyataan pada kalimat 2 , serta kata memukul dan menginjak mengidentifikasikan bahwa pelaku telah melakukan penganiayaan pada korban. Kalimat 1 memberi informasi bahwa yang melakukan pengeroyokan adalah debt collector. Kalimat 2 memberi informasi bahwa motor korban memang menunggak sehingga korban berjanji membayar tunggakannya keesokan harinya bahkan bersedia menulis surat pernyataan. Kalimat 3 memberi informasi tentang perlakukan pelaku pada korban yang memukul dan menginjak. Kalimat 1, 2, dan 3 di atas memberi kesan bahwa pelaku telah berbuat salah karena telah memukul dan menginjak korban, padahal korban telah berjanji untuk melunasi tunggakan. Strategi identifikasi dalam teks berita bertujuan untuk menunjukkan perilaku kasar pelaku dalam peristiwa pengeroyokan tersebut.

\section{Teks berita 6}

Gara-Gara Bertanya Kapan Dinikahi, Gadis Asal Jl Veteran Makassar Ini Dianianya Pacar

Kamis, 27 Oktober 2016 08:19 Laporan wartawan Tribun Timur Hasan Basri

TRIBUN-TIMUR.COM, MAKASSAR --AS (29), seorang perempuan asal JL Veteran Makassar melaporkan kekasihnya IS ke Polsek Tamalate Makassar. Isi laporanya, ia mendapatkan tindakan kekerasan yang dilakukan kekasihnya itu. 
Totobuang, Vol. 6, No. 1, Juni 2018: 1-15

IS menceritakan ihkwal yang menimpa dirinya, ketika menpertanyakan keseriusan IS untuk melamarnya, sejak 20 September 2016 lalu. Namun naasnya, niat baik AS justru mendapat perlakuan kasar.

"Datangka di rumahnya baik-baik pak hanya mengingatkan janjinya untuk melamarku sesuai janjinya. Tapi malah dia menganiaya saya,"kata As kepada wartawan, Rabu (26/10/2016).

Kekasihnya langsung menonjok wajahnya. Penganiayaan kekasihnya itu mengakibatkan korban mengalami memar pada bagian dahi sebelah kiri, dagu sebelah kiri, perut dan bahu sebelah kiri.

AS mengaku mendatangi lelaki itu, hanya untuk memperjelas perjanjian yang telah mereka sepakati dengan keluarganya untuk melamarnya bulan ini. Musabahnya, As merasa malu dengan keluarganya yang sudah diketahui para tetangganya.

"Alasanya, karena uang panai. Tapi saya sudah sampaikan kalau keluarga saya tidak akan mempemasalahkan itu, cukup Rp 5 juta saja. Namun, masih saja mengaku tidak punya uang, "paparnya.

Atas perlakuan IS, gadis inipun langsung melaporkan ke Polisi pasca setelah kejadian. Sekedar diketahui, kasus ini telah dalam penyelidikan Kepolisian. Beberapa saksi dari keluarga IS telah dimintai keterangan seputar insiden penganiayaan itu. $\left({ }^{*}\right)$

Strategi wacana yang digunakan pada judul teks berita 'Gara-Gara Bertanya Kapan Dinikahi, Gadis Asal Jl Veteran Makassar Ini Dianianya Pacar' adalah strategi identifikasi. Strategi identifikasi ditunjukkan dalam kalimat Gara-gara Bertanya Kapan Dinikahi. Konstruksi kalimat pertama pada judul teks menjelaskan konstruksi kalimat selanjutnya yang menunjukkan akibat dari pertanyaan korban (Gadis Asal Jl. Veteran Makassar Ini Dianiaya Pacar). Dalam judul teks, wartawan Tribun Timur memberi informasi bahwa penganiayaan yang diterima korban merupakan akibat dari pertanyaan korban. Penggunaan strategi identifikasi oleh wartawan Tribun Timur memberi kesan memarginalkan posisi korban dalam judul teks berita.

Pada bagian isi berita, strategi wacana yang digunakan adalah strategi nominalisasi, seperti yang terlihat dalam kalimat berikut:

1) AS (29), seorang perempuan asal JL Veteran Makassar melaporkan kekasihnya IS ke Polsek Tamalate Makassar.

2) Isi laporannya, ia mendapatkan tindakan kekerasan yang dilakukan kekasihnya itu.

3) AS mengaku mendatangi lelaki itu, hanya untuk memperjelas perjanjian yang telah mereka sepakati dengan keluarganya untuk melamarnya bulan ini.

Kalimat 1 menampilkan korban apa adanya dengan memberi informasi kepada pembaca bahwa seorang perempuan asal $\mathrm{Jl}$ Veteran melaporkan kekasihnya ke polisi. Kalimat 2 menginformasikan alasan korban melaporkan pacar korban ke polisi, dan kalimat 3 menginformasikan kepada pembaca alasan korban mendatangi pelaku di rumahnya. Strategi nominalisasi dalam ketiga kalimat di atas menampilkan korban apa adanya tanpa kesan negatif.

Strategi identifikasi pada bagian isi berita dapat ditemukan dalam kalimat berikut:

1) Namun naasnya, niat baik AS justru mendapat perlakuan kasar.

2) Penganiayaan kekasihnya itu mengakibatkan korban mengalami memar pada bagian dahi sebelah kiri, dagu sebelah kiri, perut dan bahu sebelah kiri.

Kalimat 1 dan 2 menginformasikan kepada pembaca tentang perlakuan pelaku 
kepada korban. Hal tersebut memberi kesan bahwa pelaku memiliki sifat yang kasar.

\section{Teks berita 7}

Pria Maros Pembunuh Istri Gara-gara Ditolak Nafsunya Divonis 15 Tahun

Rabu, 12 Oktober 2016 16:19

Laporan Wartawan Tribun Timur, Ansar Lempe

TRIBUN TIMUR.COM, MAROS - Terdakwa kasus pembunuhan istri, Amir alias Hamiro (60) warga Dusun Berua, Desa Salenrang, Kecamatan Bontoa, Maros, Sulawesi Selatan, divonis 15 tahun penjara oleh Majelis Hakim Syahbuddin didampingi Fifianti dan Jeni Tula, Rabu (12/10/2016).

Putusan hakim Pengadilan Negeri (PN) tersebut sama dengan tuntutan jaksa penuntut umum (JPU) Kejari Maros, Koharuddin. Terdakwa terbukti membunuh istrinya sendiri, Rabiah (51).

Kepala Seksi Intelijen (Kasiintel) Kejari Maros Hari Surahman menyampaikan, terdakwa dijerat pasal 44 ayat 3 Undang-undang nomor 23 tahun 2014 tentang kekerasan dalan rumah tangga dengan ancaman 15 tahun penjara.

"Pelaku pembunuhan istrinya sendiri, Amir alias Hamiro sudah divonis 15 tahun oleh majelis hakim. Putusan ini sama dengan tuntutan jaksa," kata Hari.

$\mathrm{Hal}$ yang memberatkan terdakwa yakni, menghilangkan nyawa orang lain, memberikan keterangan berbelit-belit saat persidangan, meresahkan masyarakat dan menyalahkan korban.

"Terdakwa ini masih menyalahkan korban, karena istrinya ini tidak mau melayaninya. Makanya, terdakwa ini marah dan menusuk istrinya di rumahnya sendiri," ujarnya.

Dalam persidangan, Hamiro mengaku menghabisi nyawa istrinya Rabiah dengan membacok menggunakan parang, Sabtu (16/4/2016) lalu, karena korban sudah tiga kali menolak untuk berhubungan intim.
Korban tewas sekitar pukul 5.00 wita setelah tubuhnya dipenuhi luka sabetan parang. Saat itu, pelaku menutup dan mengunci rumahnya, sehingga korban tidak bisa melarikan diri. Terdakwa tersebut ditahan di Lembaga Pemasyarakatan (Lapas) Maros. Dia langsung digiring setelah proses persidangan selesai.

Strategi wacana yang digunakan dalam judul teks berita 'Pria Maros Pembunuh Istri Gara-gara Ditolak Nafsunya Divonis 15 Tahun' adalah strategi nominalisasi. Strategi nominalisasi dalam judul teks ditandai dengan menampilkan pelaku dengan apa adanya dalam pemberitaan, sehingga strategi nominalisasi dalam judul bertujuan untuk menginformasikan vonis hakim terhadap pelaku.

Strategi wacana yang digunakan dalam isi berita adalah strategi nominalisasi. Hal tersebut terlihat dalam kalimat di bawah ini:

1) Terdakwa kasus pembunuhan istri, Amir alias Hamiro (60) warga Dusun Berua, Desa Salenrang, Kecamatan Bontoa, Maros, Sulawesi Selatan, divonis 15 tahun penjara oleh Majelis Hakim Syahbuddin didampingi Fifianti dan Jeni Tula, Rabu (12/10/2016).

2) Terdakwa terbukti membunuh istrinya sendiri, Rabiah (51).

Kata terdakwa, pembunuhan, dan divonis 15 tahun penjara dalam kalimat 1 memberikan informasi kepada pembaca bahwa pelaku mendapatkan vonis hukuman 15 tahun penjara. Pada kalimat 2, kata terdakwa dan membunuh istrinya memberi informasi kepada pembaca bahwa yang menjadi korban dari pembunuhan tersangka adalah istri tersangka. Dalam 2 kalimat di atas, pelaku ditampilkan apa adanya, sedangkan korban ditampilkan sebagai objek dalam pemberitaan. 
Pada teks berita juga ditemukan strategi identifikasi. Hal tersebut terlihat dalam kalimat berikut:

1) Hal yang memberatkan terdakwa yaitu, menghilangkan nyawa orang lain, memberikan keterangan berbelit-belit saat persidangan, meresahkan masyarakat dan menyalahkan korban.

2) Terdakwa ini masih menyalahkan korban, karena istrinya ini tidak mau melayaninya.

3) Korban tewas sekitar pukul 5.00 wita setelah tubuhnya dipenuhi luka sabetan parang. Saat itu, pelaku menutup dan mengunci rumahnya, sehingga korban tidak bisa melarikan diri.

Kata terdakwa pada kalimat 1 dan 2 yang diidentifikasikan dengan frasa hal yang memberatkan pada kalimat 1 dan frasa masih menyalahkan korban pada kalimat 2 menunjukkan bahwa pelaku yang telah terbukti bersalah menganggap dirinya tidak bersalah dan akhirnya memberi keterangan yang berbelit-belit dalam persidangan. Hal tersebut menunjukkan bahwa pelaku menganggap tindakannya membunuh istrinya wajar.

Penggunaan strategi identifikasi dalam kedua kalimat di atas menunjukkan bahwa wartawan Tribun Timur menginformasikan kelakuan buruk tersangka (memberikan keterangan berbelitbelit saat persidangan, meresahkan masyarakat dan menyalahkan korban). Pada kalimat 3, korban diidentifikasikan tidak berdaya karena tidak bias melarikan diri. Perbuatan pelaku yang mengunci pintu rumah sehingga korban tidak bias keluar menunjukkan kekejaman pelaku.

Strategi nominasi dan identifikasi yang ditemukan dalam teks berita termasuk ke dalam kelompok strategi wacana inklusi, sedangkan strategi wacana eksklusi tidak ditemukan dalam teks berita yang dianalisis. Strategi wacana inklusi adalah strategi wacana yang dapat digunakan jika menginginkan sesuatu, seseorang, atau kelompok ditampilkan dalam teks. Adapun strategi wacana eksklusi adalah strategi yang digunakan untuk mengeluarkan atau menghilangkan salah satu aktor sosial, bisa berupa kelompok atau seseorang, dari pemberitaan. Oleh karena itu, kecenderungan penggunaan strategi wacana inklusi dalam teks berita daring Tribun Timur menunjukkan bahwa pola pemberitaan teks berita daring Tribun Timur selalu menampilkan semua aktor sosial (korban dan pelaku) yang terlibat dalam peristiwa tindak kekerasan.

\section{PENUTUP}

Berdasarkan hasil analisis teks berita daring Tribun Timur yang dianggap merepresentasikan korban kekerasan terlihat bahwa bentuk kebahasaan berita yang merepresentasikan korban kekerasan pada situs Makassar.tribunnews.com adalah kata dan kalimat yang mengandung strategi wacana nominasi dan identifikasi yang termasuk dalam strategi wacana inklusi. Penggunaan strategi wacana nominasi untuk merepresentasikan korban kekerasan menunjukkan bahwa karakteristik pemberitaan korban kekerasan dalam teks berita Tribun Timur cenderung menampilkan semua aktor atau korban kekerasan. selain itu, tidak ditemukannya strategi wacana eksklusi dalam data yang dianalisis menunjukkan bahwa teks berita daring Tribun Timur selalu menampilkan semua aktor sosial yang terlibat dalam peristiwa tindak kekerasan, tanpa mengeluarkan salah satu aktor sosial yang terlibat dalam peristiwa tindak kekerasan tersebut.

Pada teks berita, korban kekerasan laki-laki cenderung ditampilkan dengan strategi nominasi yang menampilkan korban dengan apa adanya, namun untuk korban kekerasan perempuan terlihat kecenderungan ditampilkan dengan strategi identifikasi yang menampilkan korban sebagai pihak yang tidak berdaya. Korban laki-laki dalam teks berita daring Tribun Timur cenderung lebih dilindungi dibandingkan korban perempuan. Hal 
tersebut dapat mengindikasikan bahwa wartawan Tribun Timur masih cenderung menganut ideologi patriarki, namun di sisi lain dengan adanya kecenderungan pemfokusan korban perempuan sebagai pihak yang tidak berdaya juga dapat mengindikasikan bahwa wartawan Tribun Timur ingin agar korban kekerasan perempuan lebih diperhatikan nasibnya.

\section{DAFTAR PUSTAKA}

Eriyanto. 2003. Analisis Wacana; Pengantar Analisis Teks Media. Yogyakarta: LKiS Yogyakarta.

Fauziah, \& Tamampil, Armis. 2015. "Representasi Perempuan Dalam Pemberitaan KDRT di Media Massa Pada Masyarakat di Wilayah Jakarta (Studi Pemberitaan Kekerasan Dalam Rumah Tangga di Merdeka.com dan Kompas.com)". PROMEDIA, Vol.1, No. 1:131-158.

Galtung, Johan. 2002. Kekerasan Budaya. Jakarta: Ghalia Indonesia.

Hall, Stuart. 2003. Representation: Cultural Representation and Signifying Practices. London: Sage Publication.

Hasanah, Hasanah. 2013. "Kekerasan Terhadap Perempuan dan Anak dalam Rumah Tangga Perspektif Pemberitaan Media”. SAWWA, Vol. 9, No. 1:159-178.

Hufad, Ahmad. 2003. "Perilaku Kekerasan: Analisis Menurut Sistem Budaya dan Implikasi Edukatif'. Mimbar Pendidikan, Vol. 2, No. XXI:52-61.
Juditha, Christianty. 2015. "Dilematis Media dalam Pemberitaan Konflik dan Kekerasan". Acta diurnA, Vol. 11, No. 1: 15-34.

Leeuwen, Theo Van. 2008. Discourse and Practice; New Tools For Critical Discourse Analysis. New York: Oxford University Press.

Setiawan, Yuliyanto Budi. 2011. "Analisis Wacana Kritis Pemberitaan Kekerasan Berbasis Gender Di Surat Kabar Harian Suara Merdeka". Jurnal Ilmiah Komunikasi/MAKNA, Vol. 2, No. 1:13-20.

Sudaryanto. 1993. Metode dan Aneka Teknik Analisis Bahasa: Pengantar Penelitian Wahana Kebudayaan Secara Linguistik. Yogyakarta: Duta Wacana University Press.

Suwarno. 2012. "Analisis Perilaku Kekerasan Massa dan Upaya Penanggulangannya". Seminar Hasil Penelitian dan Pengabdian Kepada Masyarakat FISIP Unila (pp. 4657). Lampung: Unila.

Suganda, Dadang, dkk. 2007. "Representasi Sosok Tenaga Kerja Wanita (TKW) Indonesia dalam Wacana Berita Pada Harian Umum Utusan Malaysia dan Harian Umum Kompas Indonesia (Kajian Analisis Wacana Kritis)". Simposium Kebudayaan Indonesia Malaysia X (pp. 1-55). Selangor, Malaysia: Fakultas Sastra Universitas Padjadjaran.

http://www. makassar.tribunnews.com// 



\begin{tabular}{|lcc|}
\hline & TOTOBUANG & \\
\hline Volume 6 & Nomor 1, Juni 2018 & Halaman 17-31 \\
\hline
\end{tabular}

\title{
REMAJA KERING DALAM PEMBACAAN DURUM (Lonely Teenagers in "Durum" Reading)
}

\author{
Resti Nurfaidah \\ Balai Bahasa Jawa Barat \\ Jalan Sumbawa Nomor 11, Bandung 40113 \\ Pos-el: sineneng1973@gmail.com
}

(Diterima: 28 Mei 2018; Direvisi: 30 Mei 2018; Disetujui: 5 Juni 2018)

\begin{abstract}
Abstrak
This article entitled "The exhaustic Adolescent on Durum Reading". Durum is one of the compulsary scripts in Festival Drama Sunda Basa 2017. Durum is a massive script - solid in characters and content of the story-. The script conveys factors that cause conflict in teenagers life and the impact that occurs due the losing thefamily's ideality. The identification problem in this artical was just focused on adolencent's conflict and family along its impact against himself/herself and their surroundings. The purpose of this study revealed the background of their conflict through the symbolof each sceneand their psychological aspects This artical used semiotics of John Fiske and developmental psychology of Hurlock as its theoretical concepts. Anyway, the research method used qualitative with descriptive analysis. The results showed that there were intergenerational gap among adolescents with all their contemporary values with the older generation and social values that wer considered as an old-fashioned; lossing of closeness and harmonious communication between parent and adolescent, as well as between parents themselves; the high pressure of hedonistic and materialistic life; also an individualist lifestyle that no longer understood the meaning of understanding and caring among people. The exhaustic adolescent represented family and environtmental disharmony.
\end{abstract}

Keywords: Durum, adolescent, conflict, semiotic, phsychology

\begin{abstract}
Abstrak
Artikel ini berjudul "Remaja Kering dalam Pembacaan Durum”. Durum merupakan salah satu naskah unggulan dalam Festival Drama Basa Sunda 2017. Durum merupakan naskah yang masif (padat dalam pemeranan dan muatan cerita). Naskah tersebut menyampaikan faktor-faktor penyebab timbulnya konflik dalam kehidupan remaja dan dampak yang terjadi akibat kehilangan idealitas di dalam lingkungan keluarga. Identifikasi masalah dalam artikel ini dibatasi pada konflik remaja dan lingkungan keluarganya serta dampaknya terhadap diri si remaja maupun lingkungan di sekitarnya. Tujuan penelitian ini adalah untuk mengungkapkan latar terjadinya konflik remaja melalui telaah pada simbol adegan serta aspek psikologis remaja. Konsep teoretis yang digunakan dalam artikel ini adalah semiotika John Fiske dan psikologi perkembangan Hurlock. Metode penelitian yang digunakan ialah kualitatif dengan analisis deskriptif. Hasil yang diperoleh dalam penelitian tersebut adalah adanya kesenjangan antargenerasi: antara remaja dengan segala nilai kontemporernya dengan generasi tua dan nilai-nilai sosial yang dianggap kolot; hilangnya kedekatan dan komunikasi harmonis antara orangtua dan remaja, serta antarorang tua sendiri; tekanan kehidupan hedonistis dan materialistis yang cukup tinggi; pola hidup individualis yang tidak lagi memahami arti pengertian dan kepedulian antarsesama manusia. Remaja kering merupakan bukti atas ketidakharmonisan keluarga dan lingkungan setempat.
\end{abstract}

Kata-kata kunci:durum, remaja, konflik, semiotika, psikologi

\section{PENDAHULUAN}

Zaman bergerak secepat pergerakan angin, bahkan dapat dikatakan tidak terukur. Munculnya serangkaian fenomena baru seakan mewarnai peradaban manusia. Globalisasi ditenggarai sebagai sumber dari segala sumber perubahan yang cepat tersebut. Diibaratkan seperti arus yang deras, globalisasi menjadi malaikat kematian terhadap serangkaian batas-batas wilayah, batas-batas etika dan norma sosial, batasbatas adat dan tradisi, tetapi meninggalkan sekaligus menebarkan jejak keragaman, sebaran etika dan norma yang baru. Banyak 
pula yang mengatakan bahwa wajah dunia seolah dimiripkan dengan segala aspek kehidupan manusianya. Yang paling dikhawatirkan dengan perubahan tersebut adalah kaum muda, yang dengan segala keluasan pengetahuannya seolah mampu menaklukan teknologi dengan gawai canggihnya. Gawai yang mampu membawa mereka ke dunia yang jauh, menelan mentah-mentah pengaruh Barat, bertahap meninggalkan keribetan pakem tradisi dan menjauhkan dunia yang dekat di antara mereka. Pengaruh-pengaruh nilai baru yang seolah cenderung menjanjikan kebebasan dan kemudahan, yang tidak didasari dengan akar-akar pemahaman akan risiko besar yang ditanggungnya, lalu banyak mendatangkan cobaan yang luar biasa di dalam kehidupan para remaja. Tentu saja, dalam satu sisi, pengaruh-pengaruh baru Barat juga memiliki sederet nilai positif, di antaranya daya kreativitas remaja yang luar biasa, ditambah dengan kemajuan dunia digital memudahkan mereka untuk berkarya dan berprestasi. Hanya saja, sungguh disayangkan jika tanpa didasari pandangan yang luas, dan dasar pemahaman yang tinggi, remaja seolah kehilangan kendali. Kehidupan instan seperti yang kerap kali ditayangkan dalam sinetron melekat erat dalam-dalam dan lambat laun menyusutkan daya juang mereka.

Remaja tidak pernah lepas dari lingkungan keluarganya. Remaja yang digandangkan sebagai masa usia labil, pencarian jati diri, penuh ketakutan, tidak realistis dan cenderung subjektif, ambivalensi tinggi terhadap perubahan dan risiko yang dihadapi, dan sebagainya. Idealnya, remaja yang berada dalam masa peralihan tersebut tetap berada di dalam pengawasan kedua orang tuanya, keluarga besar, dan lingkungan sosialnya. Namun, tidak semua remaja beruntung mendapatkan idealitas tersebut. Adakalanya, pada masa remaja itulah mereka terjerumus ke dalam kegelapan. Lepasnya pengawasan orang tua, renggangnya hubungan dengan saudara, kondisi dan situasi lingkungan sosial yang cenderung individualistis, ditambah dengan budaya materialis dan narsistis yang cukup deras serangannya, semakin memudahkan remaja untuk menjadi rapuh. Sisi gelap masa remaja itulah yang dimunculkan dalam beberapa naskah Festival Drama Basa Sunda (FDBS) 2017 yang diselenggarakan oleh Teater Sunda Kiwari. Lima naskah unggulan dijadikan sebagai naskah pilihan peserta, yaitu Belis, Pasalia, Durum, Salayar Dami, dan Pret. Kelima naskah tersebut menunjukkan polemik dalam kehidupan manusia masa kini. Terkecuali Belis, empat naskah lain berbicara tentang kelamnya kehidupan remaja saat ini. Keempat naskah tersebut memberikan gambaran kehidupan remaja yang sudah kehilangan idealitas keluarga dan lingkungan sosialnya. Mereka menjadi kesepian. Dengan dasar sebagai makhluk sosial, remaja melampiaskan kerinduan akan idealitas tersebut pada berbagai alternatif yang rupanya menjebak mereka sendiri sebagai korban yang baru. Sedianya, artikel ini akan membahas keempat naskah tersebut, tetapi keterbatasan waktu menyebabkan bahasan ini hanya diarahkan pada satu naskah, yaitu Durum.

Durum ditulis oleh E.D. Jenura. Durum merupakan singkatan dari Dunia Rumaja 'Dunia Remaja'. Dapat dikatakan bahwa Durum merupakan drama yang padat dengan deretan fragmen masalah dalam kehidupan remaja yang padat. Semua adegan berisi, tidak sambung menyambung, plot naik-turun, dan dialog yang cukup mengaduk-aduk emosi penonton. Durum menyajikan remaja yang lepas dari pengawasan orang tua, orang tua yang lepas dari pakem perkawinan, konsep percintaan yang sudah melenceng jauh, hilangnya konsep keteladanan, dan gaya tontonan masyarakat masa kini yang cenderung hedonis, terangkai dalam ketidaksinambungan antaradegan, serta banyaknya karakter yang dihadirkan, tetapi memberikan keutuhan tentang pencitraan remaja kering saat ini. Durum secara masif menyampaikan serangkaian faktor dan 
dampak kehilangan idealitas tersebut. Karakter yang ditampilkan dalam drama tersebut adalah Dalang, Satu, Dua, Tiga, Empat, Kesih Sukesih, Aji Kataji, Kutu Buku, Cacing Cau, Suami, Istri, Junkie, Penyiar, Aktris, dan Aktor. Latar tempat dan situasi dibuat absurd, tidak disebutkan dengan jelas. Hanya saja, di panggung tersedia sebuah properti yang menggambarkan layar monitor, kotak-kotak besi yang menggambarkan remote control dan gawai, serta gulungan tambang besar yang tersambung pada sebuah. Durum yang menjadi fokus bahasan dalam artikel ini adalah yang dipentaskan di Jambore Sastra 2017 di Yogyakarta. Jambore Sastra 2017 merupakan pagelaran tahunan beberapa anggota tetap di wilayah Indonesia Tengah yang meliputi balai dan kantor di wilayah Jawa, Banten, Bali, NTB, NTT, dan Kalimantan. Sebagai wakil dari Jawa Barat, Balai Bahasa Jawa Barat menunjuk Teater Gawe SMKN 3 Tasikmalaya, salah satu peserta dalam FDBS 2017.

\section{LANDASAN TEORI}

Konsep yang digunakan dalam artikel ini adalah semiotika Fiske dan psikologi perkembangan Hurlock. Remaja sebagai bagian dari tahapan perkembangan manusia dianggap sangat unik, terutama pada aspek kelabilan (moral dan emosi) serta kepesatan fisik. Konflik dalam kehidupan remaja, menurut Hurlock (2013:231-232), bermula pada kesalahan kedua belah pihak, remaja-orang tua. Orang tua sulit melepaskan sifat naluriahnya, yaitu menganggap remaja mereka sebagai anak kecil. Orang tua cenderung memperlakukan mereka sebagai anak kecil, tetapi di sisi lain, mereka mengharapkan si remaja untuk bertindak sesuai dengan usianya saat itu. Kesalahan remaja adalah sulit menerima perlakuan tersebut. Hal lain yang paling mendasar adalah kesenjangan generasi (Hurlock, 2013:232). Hurlock memandang bahwa kesenjangan tersebut kebanyakan diakibatkan oleh perubahan radikal dalam nilai dan standar perilaku yang biasanya terjadi dalam perubahan budaya yang sangat cepat. Kesenjangan generasi yang paling menonjol adalah di bidang norma sosial. Norma sosial yang muncul dalam kehidupan remaja saat ini, misalnya, merupakan tabu dalam kehidupan generasi orang tua pada masa remaja dulu. Konflik akan semakin meruncing jika ditambahkan dengan ketidakmampuan remaja untuk berkomunikasi dengan orang tua dan generasi sebelumnya yang lain. Orang tua banyak yang sulit menerima kenyataan atas pembangkangan remaja pada laranganlarangan tertentu, sementara si remaja memandang orang tuanya tidak bisa mengerti keinginannya. Teja (2016) menyampaikan tujuh pilar pengasuhan anak Elly Risman sebagai solusi untuk menjembatani kesenjangan antargenerasi tersebut, antara lain, orang tua harus sepenuhnya ada untuk anak, membangun ikatan yang kuat dengan anak, menetapkan tujuan pengasuhan yang jelas, pengaturan gaya berbicara (tutur kata halus, sopan, baik, dan tidak bohong), orang tua harus menjadi sekolah religi pertama bagi anak, memiliki persiapan pola pengasuhan anak saat remaja, serta mengajari anak menahan pandangan. Sementara itu, Hapsari (2012) menyampaikan bahwa menghadapi remaja memerlukan strategi tersendiri. Jika terlalu keras, remaja akan melampiaskan pencarian oase di luar rumah, sebaliknya, jika terlalu longgar, remaja akan mudah terjerus ke dalam kesesatan, seperti pergaulan bebas. Hapsari menyampaikan pendapat Risman tentang kiat orang tua dalam menghadapi remaja, antara lain, memupuk sikap menerima dan bersahabat dengan remaja, mengenali hal-hal yang muncul dalam kehidupan remaja, serta membangun kepercayaan kepada remaja. Kedekatan orang tua dan remaja sedemikian penting. Jika tidak, remaja akan melarikan diri dan mencari "orang tua" baru di luar rumah dalam berbagai wujud. Paling ekstrem, kerenggangan tersebut akan memunculkan 
kenakalan remaja. Ir (2011) memberikan gambaran penyebab kenakalan remaja berikut, yaitu (1) kurangnya sosialisasi dari orang tua ke anak mengenai nilai-nilai moral dan sosial; (2) contoh perilaku yang ditampilkan orang tua (modeling) di rumah terhadap perilaku dan nilai-nilai anti-sosial; (3) kurangnya pengawasan terhadap anak (baik aktivitas, pertemanan di sekolah ataupun di luar sekolah, dan lainnya); (4) kurangnya disiplin yang diterapkan orang tua pada anak; (5) rendahnya kualitas hubungan orang tua-anak; (6) tingginya konflik dan perilaku agresif yang terjadi dalam lingkungan keluarga; (7) kemiskinan dan kekerasan dalam lingkungan keluarga; (8) anak tinggal jauh dari orang tua dan tidak ada pengawasan dari figur otoritas lain; (9) perbedaan budaya tempat tinggal anak, misalnya pindah ke kota lain atau lingkungan baru; dan (10) adanya saudara kandung atau tiri yang menggunakan obatobat terlarang atau melakukan kenakalan remaja. Ir juga menambahkan bahwa lingkungan pergaulan rema serta aturan sekolah yang kurang tegas juga dapat turut memicu kenakalan remaja tersebut.

Penelitian tentang konflik remaja telah banyak dilakukan. Rohisoh (2011:ix) dalam skripsi berjudul "Pengaruh Perhatian Orang tua Terhadap Kenakalan Remaja di MTs. Walisongo Sidowangi Kajoran, Kabupaten Magelang" menyampaikan hasil penelitian kualitatif dalam analisis deskriptif bahwa perhatian orang tua di sekolah tersebut berada pada kategori tinggi (54 anak atau 90\%), kategori sedang (3 anak atau 5\%), dan kategori rendah (3 anak atau 3\%). Sementara itu, tingkat kenakalan remaja di sekolah tersebut terdiri atas kategori tinggi (2 anak atau $3.33 \%$ ), kategori sedang (12 anak atau 20\%), dan ketegori rendah (46 anak atau 76\%). Berdasarkan penelitian kualitatif dalam hasil analisis korelasi produk momentsignifikan didapati adanya korelasi yang besar dari "Y" tabel. Pada taraf rxy 0,728 lebih 0,250 pada taraf $1 \%$ adalah 0,325 . Kemudian dihubungkan dengan pedoman interprestasi koefisien korelasi diketahui pengaruh perhatian orang tua terhadap kenakalan remaja dalam kategori kuat. Saripuddin (2009:vi) dalam skripsi berjudul "Hubungan Kenakalan Remaja dengan Fungsi Sosial Keluarga" menyampaikan bahwa terdapat hubungan negatif antara fungsi sosial keluarga dan kenakalan remaja. Semakin tinggi fungsi sosial keluarga semakin rendah kenakalan remaja, sebaliknya semakin rendah fungsi sosial keluarga semakin tinggi kenakalan remaja. Safitri (2011:ix) dalam tesis berjudul "Penanganan Kenakalan Remaja (Studi Kasus Di SMA Negeri 2 Boyolali)" mendapati dua cara penanganan yang dilakukan guru Bimbingan dan Konseling di sekolah tersebut, yaitu (1) cara kuratif atau penyembuhan bagi siswa yang terlibat kenakalan remaja ringan berupa pemanggilan serta pemberian penringatan pertama, dan (2) cara represif atau pembinaan bagi siswa yang terlibat dalam kenakalan remaja berat. Jika kenakalan tersebut berulang, pihak sekolah melakukan cara yang ketiga, yaitu pengembalian siswa kepada pihak orang tua. Artikel ini juga berkaitan dengan penelitian terhadap kenakalan remaja berupa konflik remaja dengan lingkungan keluarga inti dan lingkungan di sekitarnya, berbeda dengan kebanyakan penelitian serupa berupa studi kasus pada satu institusi, yang disajikan dalam bentuk drama. Berdasarkan pada hasil pembacaan pada kajian pustaka, kesemuanya mengaitkan kenakalan remaja dengan kondisi dan situasi keluarga yang tidak harmonis. Landasan Teori dapat dituliskan dalam subbab dengan tetap mempertimbangkan kuota $15 \%$ dari keseluruhan badan naskah. Semua sumber yang dirujuk atau dikutip harus dituliskan di dalam daftar pustaka.

\section{METODE PENELITIAN}

Artikel ini merupakan penelitian kualitatif dengan metode analisis deskriptif. Pembahasan dibatasi faktor dan dampak pengaruh zaman terhadap kehidupan remaja 
yang rapuh. Sementara itu, tahapan penelitian yang dilakukan dalam penyusunan artikel ini adalah pembacaan dan pengamatan cermat pada sumber data maupun pada pementasan; pembacaan literatur pendukung; pengolahan data berdasarkan konsep teoretis yang relevan dengan topik penelitian; dan penyampaian hasil analisis dalam bentuk artikel ilmiah. Konsep teoretis yang digunakan dalam artikel ini adalah semiotika John Fiske dan psikologi perkembangan Hurlock. Menurut John Fiske, semiotika adalah studi tentang pertanda danmakna dari sistem tanda; ilmu tentang tanda, tentang bagaimana tanda dan maknadibangun dalam "teks" media; atau studi tentang bagaimana tanda dari jenis karyaapapun dalam masyarakat yang mengkomunikasikan makna. Dalam semiotika (ilmu tentang tanda) terdapat dua perhatian utama, yakni hubungan antara tanda denganmaknanya dan bagaimana suatu tanda dikombinasikan menjadi suatu kode. Semiotik yang dikaji oleh John Fiske antara lain: level reality (realitas), yakni peristiwa yang ditandakan (encoded) sebagai realitas, berupa tampilan, pakaian, lingkungan, perilaku, gestur, suara. Selanjutnya, level representation(representasi), realitas yang terkode dalam encoded electronically harus ditampakkan pada technical codes, seperti kamera, pencahayaan, penyuntingan, musik, dan suara. Dalam bahasa tulisada kata, kalimat, proposisi, foto, grafik, dan sebagainya, sedangkan dalam bahasa gambar atau televisi ada kamera, tata cahaya, atau musik. Elemen-elemen ini ditransmisikan kedalam kode representasional yang dapat mengaktualisasikan, antara lain, karakter, narasi, latar, dan sebagainya. Terakhir, level ideology (ideologi), semua elemen diorganisasikan dan dikategorikan dalam kode-kode ideologis, seperti patriakhi, individualisme, atau ras. Ketika kita melakukan representasi atassuatu realitas, menurut Fiske, tidak dapat dihindari adanya kemungkinan memasukkan ideologi dalam konstruksi realitas.

\section{PEMBAHASAN}

Analisis terhadap naskah Durum dibagi ke dalam tiga level Fiske, yaitu level reality, level representation, dan level ideology.

\section{Durum dalam Semiotika Fiske}

Pembahasan Semiotika Fiske dalam pementasan Durum tersebut dibagi ke dalam tahapan berikut: Level Reality, level representation, dan level ideology.

\section{Level Reality}

Naskah Durum menampilkan sosok remaja yang tampil apa adanya. Dalam pementasan drama Durum, Teater Gawe menampilkan remaja yang dari segi tampilan hamper sama, konsep kostum sama. Hal itu dilakukan untuk menonjolkan persamaan nasib pada sosok remaja kering. Pada sisi lain, tata rias panggung dibuat senatural mungkin untuk menampilkan kesan remaja yang polos dan belum bisa berpikir dengan jernih dan mendalam. Tata panggung dibuat sangat sederhana. Sebuah bilah kayu dibentuk sebagai cerminan sebuah layar monitor, sebagai wakil dari mata manusia, mata masyarakat, tempat hadirnya tayangan show case yang mampu mencuci otak penontonnya. Kemudian, setiap pemain memegang sebuah kota besi yang multifungsi dalam pemaknaan. Kotak besi itu berfungsi sebagai gawai atau remote control, benda yang kini seolah menjadi kebutuhan primer dalam kehidupan manusia. Tata lampu disesuaikan dengan konflik pada setiap adegan. Tipe pemeranan setiap karakter nyaris seragam, yaitu semua karakter tampak emosional dengan penyampaian dialog yang lantang.

Gambar 1

Pementasan Drama Durum

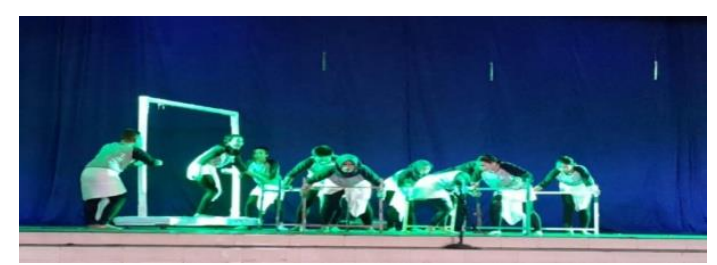

Sumber: koleksi pribadi 
Tokoh Dalang ditampilkan dengan sosok yang cenderung bergaya feodal, bingung, dan mudah kecewa dalam menghadapi perubahan, tetapi ia tidak pernah berhenti untuk membimbing anakanak remaja yang mengikutinya. Tokoh Kesih Sukesih digambarkan sebagai remaja matre yang manja dan genit. Tokoh Aji Kataji digambarkan sebagai sosok laki-laki yang metroseksual, lelaki yang memiliki ciri tubuh laki-laki tradisional, tetapi memiliki kepedulian yang tinggi terhadap kesehatan dan keindahan tubuhnya. Tokoh Kutu Buku digambarkan tidak mengenali keadaan sekeliling. Perhatiannya hanya tertuju pada bahan bacaan yang dibawanya dan waktunya selalu tercurah untuk belajar. Tokoh Cacing Cau ditampilkan sangat ketakutan dalam menghadapi tekanan dari teman-temannya. Tokoh Suami dan Istri digambarkan sangat emosional. Masingmasing berkutat dengan masalah yang tidak terselesaikan. Junkie ditampilkan sekilas sebagai sosok yang meluapkan frustrasi dengan merokok sambil mendengarkan musik fungki. Tokoh penyiar digambarkan sangat polos. Tokoh Aktris dan Aktor digambarkan bersikap sangat berlebihan. Tokoh Satu-Dua-Tiga-Empat digambarkan sebagai tokoh yang rata dengan gaya bicara yang saling bersahutan.

Gambar 2

Sebagian Karakter dalam Durum

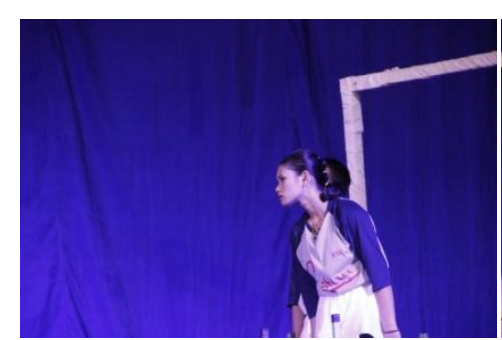

Aktris

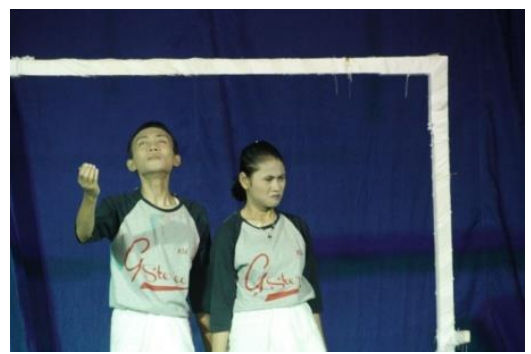

Aktor-Aktris

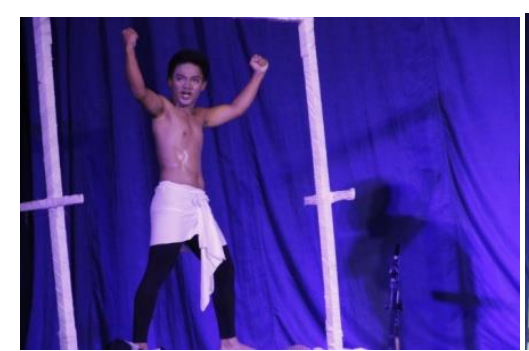

Aji Kataji

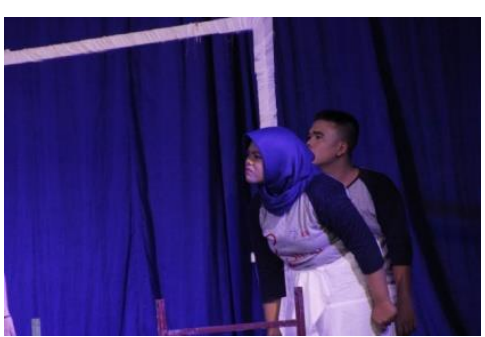

Empat

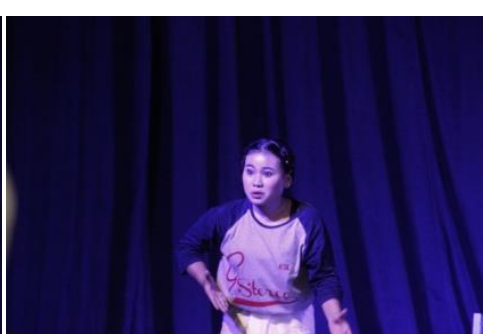

Dua

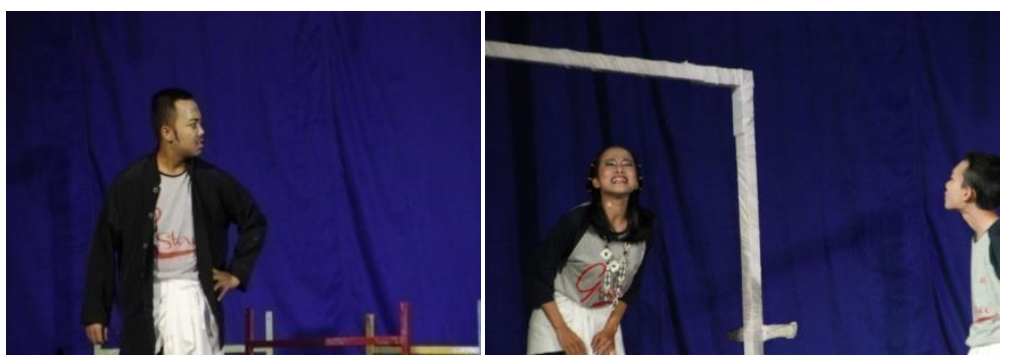

Dalang

Kesih Sukesih

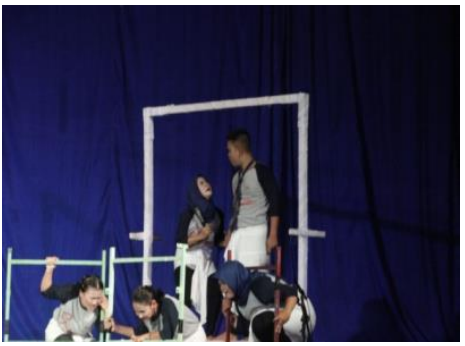

Suami-Istri

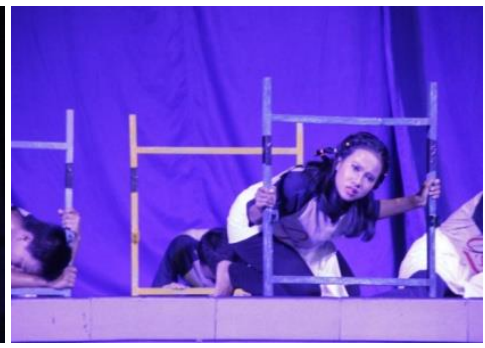

Satu

Sumber: koleksi Teater Gawe 


\section{Level Representation}

Durum menyampaikan nuansa hidup keluarga modern kebanyakan berlatar budaya urban. Pola hidup serba instan, hilangnya toleransi, lemahnya koneksi antarsesama manusia, sempitnya waktu, menyebabkan kehidupan manusia modern cenderung tergesa-gesa. Meninggalkan tradisi, nilai-nilai, dan norma sosial, manusia modern cenderung menanggalkan etika. Hubungan antara generasi muda-tua ibarat oposisi. Jurang di antara terbentang lebar. Generasi muda tampak asyik sendiri dengan gawai-gawai canggih. Kesemrawutan kehidupan urban, kota metropolitan, menjadi pembuka drama tersebut. Para tokoh berperanan ganda sebagai penduduk wilayah urban yang sibuk dengan gawai sambil berjalan bolak-balik dengan tergesa-gesa. Tenggelamnya mereka dalam keasyikan kecanggihan gawai tampak dari cara mereka memegang kotak besi itu. Seolah mereka tidak mau lepas dari alat itu. Kemudian, terdengar suara Durum ... durum ... durum... Para tokoh semua hadir dan berperanan sebagai anak muda yang tenggelam dalam dunia maya. Dunia maya yang mereka anggap sebagai surga yang semu.

\section{Gambar 3}

Generasi Gawai

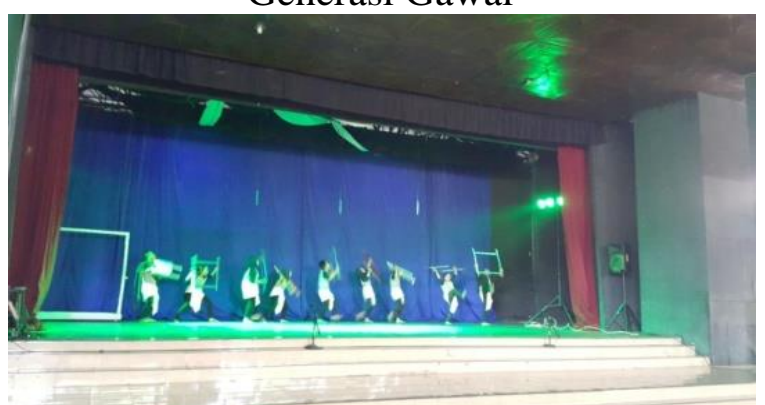

Sumber: koleksi pribadi

Langkah mereka dihentikan Dalang. Dalang menyampaikan akhir kehidupan, kematian. Ia menyampaikan bahwa ada yang mati malam itu. Dalang bertindak sebagai Aku Sang Mahatahu. Kesan "kolot" pada tokoh Dalang terlihat pada dialog yang ia ucapkan. Ia menyampaikan berita kematian berikut.

Dalang: Tidak tahu. Tapi harus ada yang mati malam ini. Begitulah, sejatinya perjalanan hidup. Coba saja perhatikan, film, serial, atau pun buku bagus, pasti harus ada karakter yang mati. Tidak mati, tidak seru! Sejatinya keindahan hidup bersembunyi di balik kematian. (Janura, 2017)

Dalang lalu menunjuk perumpamaan calon si mati kepada para remaja. mereka yang ditunjuk tampak ketakutan dan mengemukakan berbagai alasan untuk dihindari dari kematian. Kemudian, ketidakpedulian muncul, para remaja itu kembali menari dan menyanyi lagu yang sama durum ...duruuummmm... durummm.... Para remaja itu sibuk dengan masalah sinyal yang melemah. Lalu, menaruh kecewa pada gawai dan memasukkan gawai itu ke dalam saku, lalu menari lagi sambil bernyanyi durummm... durum ...duruummm. Salah satu kotak besi beralih fungsi sebagai remote control. Di layar yang besar, muncul tokoh dunia maya bernama Kesih Sukaesih. Ia menyampaikan gaya hidup hedonis dengan segala kesenangan semunya. Dalang tidak menyukai tayangan itu, tetapi para remaja sebaliknya justru menikmati gaya hidup bintang dunia maya itu. Dalang tetap menyampaikan ketidaksetujuannya terhadap pola pikir Kesih. Para remaja melancarkan protes dan mengalihkan jalur. Tayangan berpindah pada sesosok laki-laki bertubuh kekar, Aji Kataji. Ia memamerkan ototnya yang membuat para remaja wanita terhanyut. Aji Kataji sangat memperhatikan bentuk serta kesehatan tubuhnya. Ia menyampaikan tips-tips yang memikat kepada para penonton agar mereka mengikuti jejaknya. Dalang kembali menegur para remaja agar tidak terlalu yakin dengan hal-hal yang 
disampaikan oleh Aji Kataji. Di layar munncul Aktor-Aktris dalam sebuah sinetron. Tema sinetron itu adalah daun muda. Seorang pemuda gencar mengejar perempuan berusia dewasa. Perempuan itu bersikukuh untuk tidak menerima pinangan si pemuda karena ia sudah menikah. Si pemuda ngotot untuk mendapatkan cinta perempuan itu. Cerita itu terus berlanjut tiada akhir. Dalang kembali menyatakan ketidaksetujuannya dan kesenjangannya dengan para remaja tersebut. Namun, ia tidak dapat meninggalkan mereka dan tetap berteman.

Para tokoh lalu kembali menyanyi dan menari keliling panggung: durum... durum... durum.... Kemudian, muncullah tokoh Kutu Buku yang menjadi korban bullying para remaja lainnya. Adegan bullying lain ditujukan pada tokoh Cacing Cau yang juga tampak tidak berkutik ketika para remaja memerasnya. Setelah itu, seorang informan dihadirkan untuk menyampaikan latar terjadinya kasus kekerasan pada kaum remaja. Menghindari situasi serius, para remaja memindahkan jalur tayangan. Muncullah tayangan pertengkaran hebat antara tokoh Suami-Istri. Pertengakran tersebut berbasis konflik gender. Kemudian, muncullah tokoh Satu yang menyampaikan dampak dari keluarga yang tidak harmonis terhadap kehidupan kaum remaja dan anak-anak. Selain itu, tumbuh pula sikap rasa tidak hormat si anak yang berbalik menertawakan kesulitan yang dihadapi oleh orang tuanya yang diperankan oleh tokoh Dua. Berganti adegan, tampil penyiar TV lainnya yang menyampaikan kebobrokan moral seorang pejabat publik. Para remaja menunjukkan sikap tidak simpati pada tayangan tersebut, sebaliknya, Dalang menyenangi hal itu. Para remaja protes, lalu, kembali melontarkan kisruh masalah sosial di negeri ini, di antranya, konflik nasionalisme, rendahnya tingkat keterbacaan di kalangan penduduk negeri, sempitnya ruang untuk pengembangan imajinasi para remaja.
Dalang: Kenapa dimatikan?

Semua: GAk seru...!

Dalang: Nasionalisme itu penting banget buat remaja seperti kita!

Empat: Ini Dalang! Dari tadi terus aja harus ini, harus itu, ini itu. Sok bener sendiri.

Dalang: Nasionalisme itu penting!

Dua: $\quad$ Buat apa nasionalisme? Mobil bikinan Jepang! Ponsel bikinan Cina! Demokrasi dari Yunani! Angka-angka dari Arab! Nonton film lamerika! Makan pizza dan spageti dari Italia! Baju dijahit di Thailand! Musik dari Inggris! Kenapa kita harus nasionalisme?

Satu: $\quad$ Sudahlah jangan banyak bicara, Lang!

Empat: (Mengepalkan tangan kea rah Dalang) Aku gak mau lagi mendengarkan omongan si Dalang. Huruf-huruf bikin pusing, aku mau lihat gambar!

Dalang: Pemalas! Manja! Dengerin, Lur! Orang yang suka membaca dan orang yang suka nonton, jauh banget intelektualnya!

Membaca itu baik untuk memperluas imajinasi. Kalau kita suka baca buku, kita bakal dibawa berkeliling kea lam yang belum tentu terjangkau oleh 
langkah kita. Kita bisa berhenti sejenak, kita bisa merasakan keindahan isi buku, kemudian

mengembara lagi, balik lagi, berangkat lagi...

Empat: Kalau nonton film juga, kita bisa pause dulu, ke WC buat kencing, lalu nonton lagi, Lang? Кати sehat?

Dalang: Bedalah, kalau kepala kita sudah dipenuhi gambar visual, imajinasi kita terbatasi oleh...

Dua: Imajinasi! Imajinasi! Buat apa imajinasi? Imajinasi kita sudah dibunuh oleh guru, oleh orang tua, oleh kenyataan yang membuat sakit hati dan mata! Harus realistis, katanya! Cita-cita jadi dokter harus realistis! Citacita jadi astronot harus realistis! Citacita jadi presiden harus realistis! Mau jadi Bandar narkoba juga harus realistis, katanya! RE-A-LISTIS! Jadi apa gunanya imajinasi kalau belum apa-apa sudah disuruh realistis? Bunuh Imajinasi sekarang juga! Gak ada gunanya!

Semua: Bunuh...!

Dua: Bunuh komen sombong! Semua: Bunuh!

Dalang: Tapi...
Satu: $\quad$ Tapi! Tapi! Mana tombol jempol jungkir? Nanti setiap Si Dalang komen, mau di jempol jungkir! Rujit! Perusak kesenangan orang lain!

Empat: (Menarik satu menjauhi yang lain) Ssssttt... tapi kayaknya, kita juga perlu Si Dalang! Di saat hati panas, kita butuh omongan Si Dalang yang membuat kita dingin.

Satu: Berisik! Diam kamu! Empat: Siap laksanakan! (Janura, 2017)

Konflik antargenerasi mencapai puncaknya. Mereka ingin menyingkirkan Dalang. Junkie lalu muncul lalu menyanyikan lagu dugem yang diikuti oleh para remaja. Pencahayaan diarahkan pada gaya diskotik dengan pergantian warna lampu merah-hijau-biru dengan cepat, seiring irama lagu. Lagu terhenti. Remaja marah. Mereka menuding Dalang sebagai biang keladinya. Dalang lalu dikepung dan dieksekusi.

Gambar 4

Akhir Durum

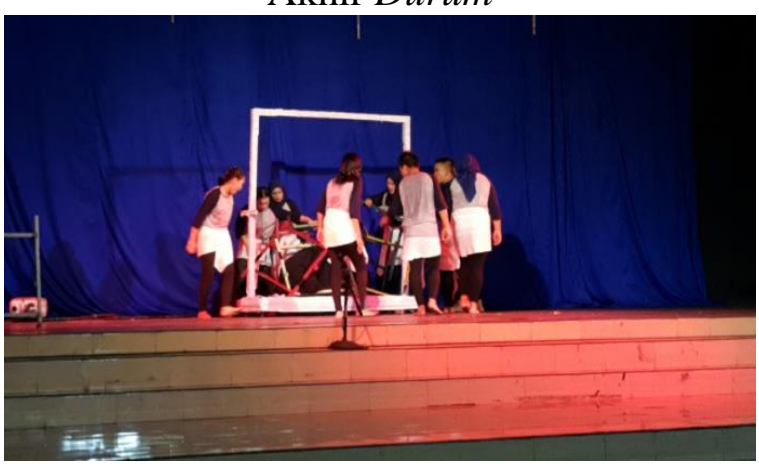

Sumber: koleksi pribadi

Level Ideology 
Remaja yang kehilangan kasih sayang dan berlomba-loba untuk mencari oase alternatif. Mereka sama-sama merasa kehilangan, kesepian, dan kekeringan. Mereka merambah dunia yang terkadang tidak pernah terpikirkan sebelumnya. Kehilangan demi kehilangan menyebabkan mereka membangun tembok resistensi sendiri, menaruh rasa benci atau merendahkan kedudukan orang tua, norma sosial, atau pakem-pakem budaya timur yang diwakili oleh tokoh dalang. Gaya hidup urban yang serba cepat dan serba tergesa tampak dari adegan hilang sinyal dalam dialog berikut.

Dalang: Remaja zaman sekarang, baru kehilangan sinyal sudah seperti mau mati saja (tertawa), Lur. Ayo, lanjutkan perjalanannya.

$\begin{array}{lr}\text { YANG LAIN } & \text { KEMBALI } \\ \text { MEMASUKKAN } & \text { HPNYA } \\ \text { SAMBIL } & \text { CEMBERUT, } \\ \text { MENGGOTONG } & \text { KABEL } \\ \text { BESAR, } & \text { BERKELILING } \\ \text { SAMBIL TERIAK } & \text { DURUM... } \\ \text { DURUM..., } & \text { KEMUDIAN } \\ \text { BERHENTI DI } & \text { DEPAN } \\ \text { LAYAR. SEMUA DUDUK DI } \\ \text { DEPAN LAYAR TERLIHAT } \\ \text { SENANG.(JanUTA, 2OI7) }\end{array}$

Gaya hidup urban yang tampak dalam Durum lainnya adalah narsis, hedonis, dan meterialistis. Sosok narsis ditampilkan oleh tokoh Aji Kataji sebagai laki-laki metroseksual. Konsep maskulinitas yang ditampilkan Aji adalah laki-laki yang peduli kesehatan dan keindahan tubuhnya, seiring hadirnya produk-produk kosmetik untuk laki-laki, termasuk peralatan pendukung seperti alat gimnastik. Laki-laki yang diidamkan oleh kaum hawa pada era modern merupakan konsep baru dalam telaah gender, khususnya maskulinitas. Konsep tersebut dapat dikatakan sebagai hibrid dari konsep maskulinitas yang ada, yaitu konsep maskuinitas tradisional yang menuntut laki- laki berpostur padat dengan otot yang terbentuk, tetapi memiliki kulit dan penampilan yang terawat. Konsep tersebut mendekati maskulinitas para pemeran drama TV Korea, seperti yang tersebut dalam penelitian Fribadi pada bagian pendahuluan tadi. Aji menjadikan hibriditas tersebut sebagai showcase laki-laki ideal yang dapat dijadikan sebagai pahlawan bagi kaum perempuan. Perempuan ditaklukan dengan keunggulan fisik dan idealitas konsep lakilaki hibrid.

Gambar 5

Aji Kataji

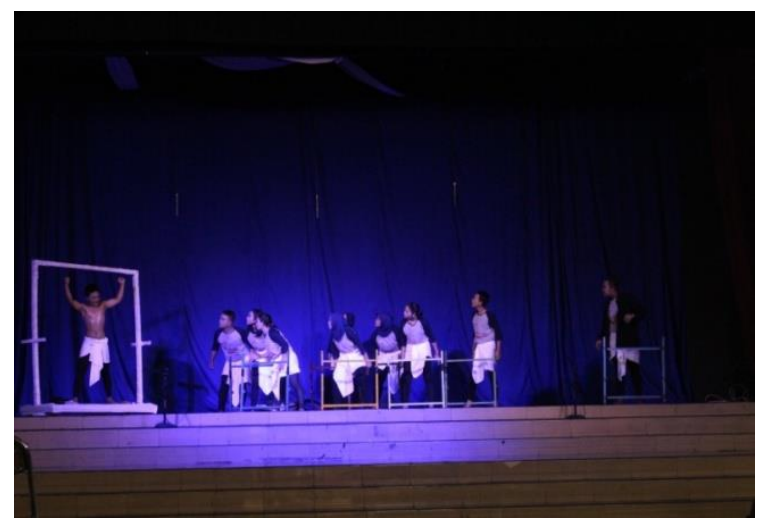

Sumber: koleksi pribadi

\section{AJI KATAJI MUNCUL DI LAYAR PERAWAKAN}

Aji : (Membuka baju) Nah, ini badanku setelah body building empat bulan. Bagus, ya? (Nyamping ke kiri, nyamping ke kanan memperlihatkan perut yang rata terlihat ototnya, mempertunjukkan bisep dan trisep gaya binaraga) Banyak banget yang bertanya bagaimana biar bisa seperti ini. Pertama, harus niat, fokus latihan. Kedua, jangan ragu-ragu mengeluarkan uang buat beli steroid, beli makanan yang bagus gizinya. Juga mengeluarkan biaya buat daftar jadi member gym. 


\section{Yang \\ lain : Waaaaahh (terpesona, mengeluarkan ponsel masing- masing), jempol! Jempol! Jempol! \\ Dua : Ganteng, seksi, duuuuhhh.... \\ Aji : Ada juga yang bertanya kenapa aku ikutan body building (tersenyum sinis). Begini. Berdasarkan hasil survey, orang fit dan ganteng, ehmmm (sok ganteng) lebih gampang hidupnya, masa depan dijamin cerah, cari kerja lebih mudah, cari pacar? Gampang, pokoknya semua gampang. (Janura, 2017)}

\section{Gambar 6}

Kesih Sukesih

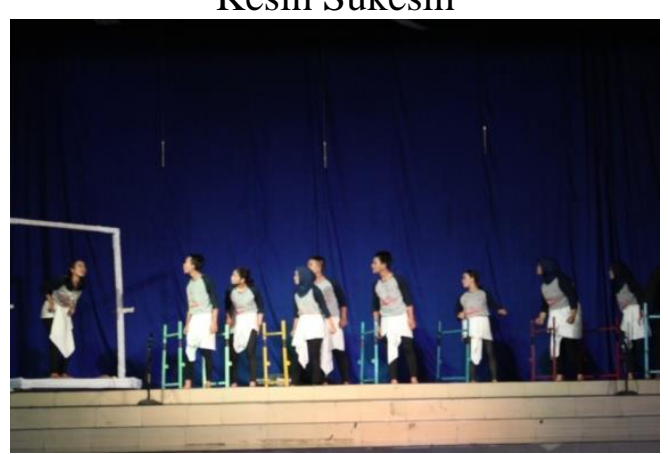

Sumber: koleksi pribadi

Gaya hidup hedonis dan materialistis ditampilkan dalam peran tokoh Kesih Sukesih. Ia menjadi simpanan seorang Om yang mampu memenuhi kebutuhannya.

Kesih: Hello, hello, hello... Bertemu kembali dengan Kesih Sukesih, si mencrang ngoncrang, di chanel kesayangan kita. Hari ini, Kesih baru saja belanja sepatu, asik (mengeluarkan sepatu dari kardus) lihat ini, ini sepatu bukan sembarang sepatu tapi Cinderella, eh? Salah, ya? Terkadang Kesih ini berasa jadi putri di negeri dongeng, dimanja Si Om kesayangan Kesih. Silahkan katanya, Kesih mau apa, nanti dibelikan Om. Aduh ... baik banget sih Om. Celengak, celengok, baragadal. Hihihihi.

[‥]

Kesih: Pokoknya, Kesih sayang banget sama Si Om, Si om juga sayang banget sama Kesih. Panggilannya Cassie seperti nama bule. Naaaah, sepatu ini juga pemberian $\mathrm{Si}$ Om, makasih ya Om, mmmuaach! Sepatu ini mau Kesih pakai buat Promt minggu depan. Apa?? Tidak tau promt? Aduh keterlaluan. Kasihan banget sih. Prompt itu pesta dansa sekolah sayang .... (Janura, 2017)

\section{Durum dalam Psikologi Perkembangan Hurlock}

Remaja yang digambarkan di dalam drama Durum merupakan remaja kering. Mereka mengalami kehilangan kedekatan dengan kedua orang tua, orang tua yang tidak harmonis, tekanan kebutuhan materi yang berat, korban bullying, dan kesenjangan nilai antargenerasi. Perseteruan karakter dengan Dalang mencerminkan kesenjangan yang sudah sangat lebar sehingga berakhir pada ekseskusi Dalang. Eksekusi tersebut menunjukkan bahwa remaja lebih memilih nilai dan norma Barat yang baru yang menurut mereka lebih benar dan menjanjikan kebebasan. Tekanan kebutuhan materi terlihat pada karakter Kesih dan karakter Salaki. Kesih menjadi simpanan seorang pria matang yang mampu memanjakannya dengan materi yang berlimpah. Sementara itu, karakter Salaki merupakan ayah patriarkis yang menjalanan peranan gender yang kaku, yaitu sebagai pencari nafkah. Beban sebagai pencari 
nafkah cukup besar sehingga ayah tidak mau menyentuh ranah domestik sedikit pun.

Gambar 7

Konflik suami-istri

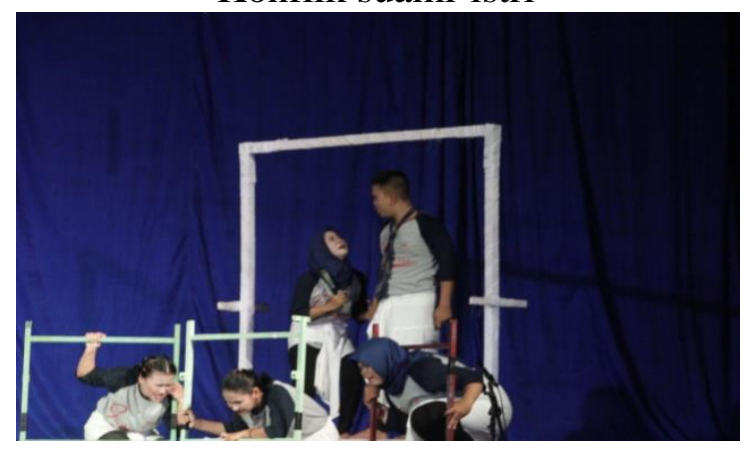

Sumber: koleksi pribadi

\section{SEPASANG SUAMI ISTRI BERKELAHI DI DALAM LAYAR}

Istri : Bukan kemauan Mamah! Bapaklah yang seperti itu! Kalau saja Bapak lebih sering di rumah, mungkin gak seperti ini! Si Honey tidak bakal hamil di luar nikah, Si Boris disayat samurai!

Suami : Harus seperti apa? Kurang apalagi? Dari pagi buta sampai sore bekerja buat menyenangkan keluarga! Merangkak dari bawah, sukasiku dengan teman, sugaksogok, sampai sekarang punya jabatan! Semua ini untuk siapa? Untuk anakanak, untuk mamah!

Istri : (Panas) Tidak cukup dengan itu! Anak-anak butuh perhatian! Mamah juga butuh perhatian.

Suami: Aing cape (Aku capek)! Maunya tuh kalau di rumah sudah tidak ada masalah apa pun! Di kantor sudah banyak urusan.

Iatri : (Menimpali) Aing ge cape! Capee!

Dua : Klik! (Janura, 2017)
Keringnya pendidikan moralitas di lingkungan keluarga memunculkan remaja yang agresif. Munculnya adegan bullying pada karakter Kutu Buku dan Cacing Cau menunjukkan alternatif pelampiasan emosi yang terpasung. Remaja pelaku tidak pernah mendapat penghargaan di dalam rumahnya sendiri. Ia berharap bahwa kedua korban tersebut dapat menghormati si pelaku yang merasa sebagai superior. Hal itu tercantum dalam adegan penyiar televisi berikut.

Suara

Berita: penyebab perilaku agresivitas pada diri remaja bisa berasal dari dua faktor, yaitu faktor internal dan faktor eksternal. Faktor internal, misalnya perasaan frustrasi, perasaan negative, pikiran atau kognisi, dan pengalaman masa kecil. Sedangkan faktor eksternal bisa berupa serangan, pengaruh teman, pengaruh kelompok, pengaruh model. Pengaruh model yang dimaksudkan adalah anak akan meniru perilaku orang yang dianggapnya dekat selama ini dengan anak. Meniru perilaku orang lain sebagai modelnya sesuai dengan teori belajar sosial yang dikemukakan oleh psikolog Albert Bandura. Sementara data daro kepolisian menyebutkan 75 kasus kekerasan remaja dan 90,3\% pelakunya berusia 13-18 tahun. Remaja sebagai pelaku kekerasan terus mengalami peningkatan sebesar 5\% tiap tahunnya. (Janura, 2017)

Pengarang menyertakan data-data ilmiah dalam drama. Selain sebagai pengetahuan yang ingin disampaikan pada penonton, adegan tersebut menunjukkan 
bahwa ketertarikan kaum remaja terhadap konsep belajar sangat kurang. Terbukti dengan sikap mereka pada bagian akhir adegan itu, mereka sibuk mematikan layar sambil berteriak "klik!"

Selain keluarga, remaja juga telah kehilangan keteladanan dari lingkungan sekitar. Sosok public figure yang hadir dalam layar seolah tidak memiliki kualitas keteladanan. Artis-artis broken home, perilaku sex bebas, tercabutnya batas-batas rumah tangga, permainan akidah. Hal itu tercermin dalam adegan berikut.

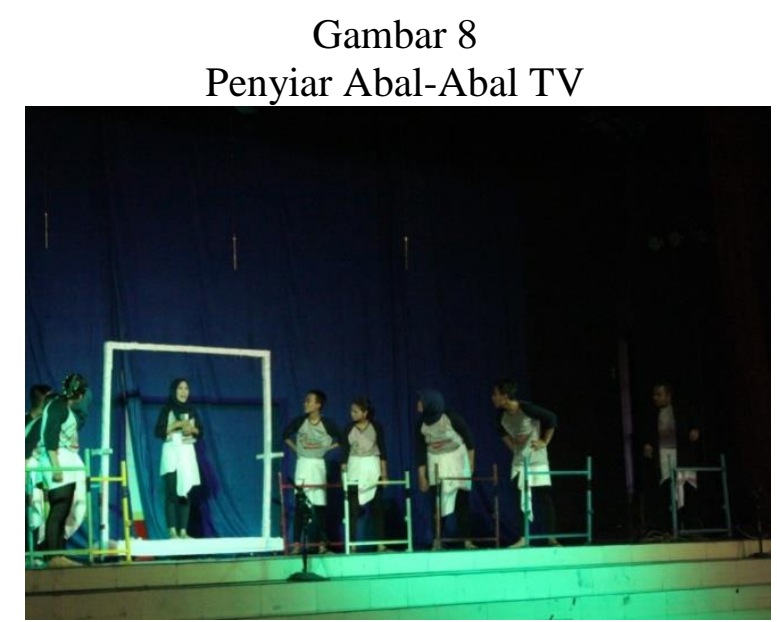

Sumber: koleksi pribadi

Penyiar: Selamat malam, pemirsa live streaming dari Abal-Abal TV, mala mini akan menyampaikan berita tidak begitu penting untuk orangorang yang mudah dimanipulasi! Ingat harus reaktif, ya? Berita gembira, baru saja anggota dewan yang tertangkap kamera CCTV sedang pesta sabu di hotel anu. (Janura, 2017)

Keluarga disharmonis menyebabkan timbulnya obsesi para remaja untuk mendapati figur atau hal-hal yang dapat menjadi pemeranan pengganti pemberi kasih sayang. Namun, terkadang remaja menjadi bingung dan cenderung salah dalam memilih pilihan, seperti terlihat dalam dialog berikut. Dalam adegan tersebut, disharmonisasi keluarga juga menyebabkan hilangnya rasa hormat pada norma-norma ketimuran, adat tradisi yang berlangsung selama bertahuntahun (atau lebih), atau orang yang lebih tua. Sebaliknya, terlebih ketika orang yang lebih tua dianggap lebih kolot serta memiliki kesalahan, sikap mereka akan mengolok atau merendahkan, seperti yang muncul dalam dialog berikut.

Satu: (Berdiri pelan-pelan) Semuanya menjadi hancur. Tak ada yang abadi. Ya, seperti itu. Awalnya indah. Mamah, Bapak, kakak, dan Adik. Semuanya bahagia, penuh dengan senyuman. Rumah yang awalnya penuh ketenangan. Secepat kilat hancur berantakan. Ratih, namanya, sekretaris cantik yang merebut hati Bapak. Lalu, Mamah tidak mau keluar kamar, matanya yang teduh berubah jadi beringas. Hilang, kasih sayang. Hilang nikmatnya disayangi, dikasihi oleh ibu. Ke mana harus mencari gantinya, sama siapa? (Terpuruk dielus yang lain)

Dua: Apa yang kurang? Rumah, mobil, motor, uang, semua ada. Cukup untuk bahagia, setiap pagi bangun sambil mengucap alhamdulillaah. Tiap minggu berlibur, berkunjung ke bibi, mengunjungi nenek. Pelanpelan serakah. 'Piih, Mamih pengen liburan ke luar negeri. Piihh, masa anakanak tidak tau Singapura? Piih, Mamih pengen punya bisnis, biar aja anak-anak di rumah saja ada Bi Murni. Terus ... Kakak mau apa? 
Ade mau apa? Mobil baru, villa, perusahaan, berlian, brangkas besar, mainan setan! Mamih ngablu, Papih ngaberung. Nah 6 bulan yang lalu merupakan puncak kegembiraan., foto Papih terpampang di Koran. Pelaku korupsi. hahahahhah! Puas!

Semua: Puass...! (Tertawa)

Dua: Rasa hormat itu harus diusahakan, Papih! Kalau Papih koplok, nyanggakeun tah imbit nyungcung! (Memberi pantat)

Semua: Taaaaahhhh.... (Janura, 2017)

Gambar 9

Tokoh Satu mempertanyakan fungsi keluarga dan tokoh Dua mengolok keburukan orang tuanya

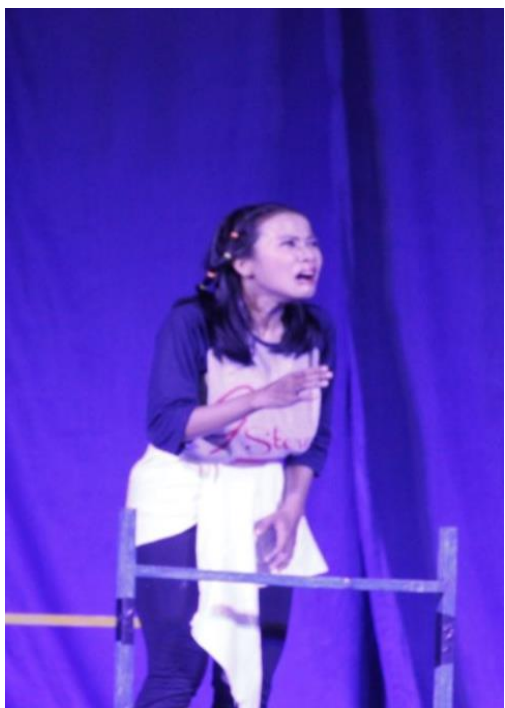

Satu

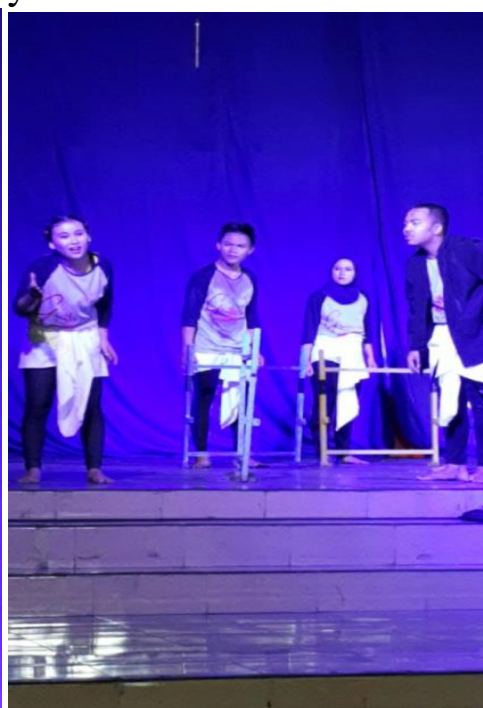

Dua

Sumber: koleksi pribadi

\section{PENUTUP}

Durum menyampaikan konflik remaja dengan lingkungan terdekat (keluarga) dan lingkungan sekitarnya. Konflik tersebut menyebabkan para remaja kekeringan dari kasih sayang dan keteladanan. Penelusuran remaja kering tersebut dilakukan dengan konsep semiotika Fiske dan psikologi perkembangan Hurlock. Dalam Fiske, eksplorasi terdiri atas tiga bagian, yaitu level reality, level representation, dan level ideology. Pada tahapan realitas, konsep pementasan Durum ditampilkan apa adanya tanpa mengenakan kostum dan tata rias yang berlebihan. Properti dan latar panggung juga tidak rumit. Pada tahapan representasi, konsep pemeranan tergolong padat dengan sederet konflik remaja yang silih berganti dan bertubi-tubi. Konsep tersebut menunjukkan bahwa konflik remaja sudah sampai pada tahapan yang cukup parah. Pada tahapan ideologi, kehidupan urban yang tidak terkendali dapat memutuskan koneksi para remaja pada nilai-nilai ketimuran, sebaliknya hal itu menimbulkan gaya hidup narsistis, hedonistis, dan materialistis. Sementara itu, berdasarkan psikologi perkembangan Hurlock, kehidupan keluarga telah terlepas dari tupoksi kewajiban dan hak antaranggota keluarga. Hal itu menyebabkan kehidupan perkawinan dan kekeluargaan menjadi retak. Terlebih sulitnya mencari konsep keteladanan, terutama pada public figure, 
menyebabkan remaja kering mencari oasis lain, yang jika salah memilih, akan mengakibatkan penderitaan bagi remaja sendiri.

\section{DAFTAR PUSTAKA}

Fiske, John. 2009. Cultural and Communication Studies: Sebuah Pengantar Paling Komprehensif. Yogyakarta : Jalasutra.

Hapsari, Endah. 2012. "Anak Anda Beranjak Remaja? Ini Cara Berkomunikasi yang Pas" http://www.republika.co.id/berita/gay a-hidup/parenting/12/01/26/lye6hsanak-anda-beranjak-remaja-ini-caraberkomunikasi-yang-pas. Diunduh 10 November 2017.

Hurlock, Elizabeth B. 2013. Psikologi Perkembangan; Suatu Pendekatan Sepanjang Rentang Kehidupan Edisi Keenam. Jakarta: Erlangga.

Ir. 2011. "10 Penyebab Kenakalan Remaja" dalam https://health.detik.com/read/2011/01 /23/100537/1552483/1075/10penyebab-kenakalan-remajadiunduh 10 November 2017, pukul 04:12 WIB.
Janura, E.D. 2017. Durum. Bandung: tidak diterbitkan.

Janura, E.D. 2017. Durum. Edisi Bahasa Indonesia diterjemahkan oleh Syamsurijal. Bandung: tidak diterbitkan.

Rohisoh, Siti. 2011. "Pengaruh Perhatian Orang tua Terhadap Kenakalan Remaja di MTs Walisongo Sidowangi Kajoran, Kabupaten Magelang". Skripsi. Salatiga: Jurusan Tarbiyah, Prodi PAI, STAIN Salatiga.

Safitri, Yuni. 2011. "Penanganan Kenakalan Remaja (Stusi Kasus di SMA Negeri 2 Boyolali)". Surakarta: Prodi MMP, Program Pascasarjana UMY.

Saripuddin, M. 2009. "Hubungan Kenakalan Remaja dengan Fungsi Sosial Keluarga". Skripsi. Yogyakarta: Prodi Sosiologi Agama, Fakultas Ushuluddin, UIN Sunan Kalijaga.

Teja, Dini. 2016. "7 Pilar Mendidik Anak Menurut Psikolog Elly Risman" dalam https://gaya.tempo.co/read/774751/7pilar-mendidik-anak-menurutpsikolog-elly-risman diunduh 10 November 2017, pukul 03:15 WIB. 



\begin{tabular}{|lll|}
\hline & TOTOBUANG & \\
\hline Volume 6 & Nomor 1, Juni 2018 & Halaman 33-45 \\
\hline
\end{tabular}

\title{
ANALISIS STILISTIKA SENO GUMIRA AJIDARMA DALAM CERPEN REMBULAN DALAM CAPUCINO: KAJIAN POSTMODERNISME JEAN FRANCOIS LYOTARD \\ (Seno Gumira Ajidarma's Literary Stylistics in "A Short Story Rembulan dalam Capucino": A Study of Jean Francois Lyotard Postmodernism)
}

\author{
Kahar Dwi Prihantono \\ Universitas Diponegoro \\ Jalan Prof Soedarto, S.H. Tembalang Semarang \\ Pos-el: akanghaar@gmail.com
}

(Diterima: 28 Mei 2018; Direvisi: 30 Mei 2018; Disetujui: 5 Juni 2018)

\begin{abstract}
The research analyzes literary stylistics of Seno Gumira Ajidarma's short story, "Rembulan dalam Capucino ",by taking advantages of Lyotard's postmodernismperspectives. By applying andescriptive method, the writer found postmodern storytelling stylistics involving at least seven postmodern styles, namely fragmentation, sublim language play, pastiche, parody, kitsch, camp, and schizophrenia. Fragmentation wasfound in the style of merging separate fragments of rembulan and creating its new meanings. Sublime language play was seen on SGA trials to change something impossible to be possible. Pastiche style was seen in the quotation of Pablo Neruda's poem which expressed it took a glance to love someone and it took a very long time to forget someone. Parodic style was seen inthe exchange of "moon" for "soto Betawi" in Italian restaurant. Camp appeared in the elimination of characters' names as in common short stories. Schizophrenia arose at SGA's story about a "moon"(rembulan) that could serve as a sign or symbol of shifted meaning between the marker and the mark. When the established meaning of the "moon"(rembulan) referred to the 'celestial bodies which surround the earth, shine at night by the reflection of the sun' and 'night beauty', SGA shifted its meaning as a burden of forgetting someone.
\end{abstract}

Keywords: literary stylistics, short story, Lyotard postmodernism, rembulan, capucino

\begin{abstract}
Abstrak
Penelitian ini menganalisis stilistika sastra Seno Gumira Ajidarma (SGA) dalam cerita pendek "Rembulan dalam Capucino” dari sudut pandang postmodern Lyotard. Dengan menggunakan metode deskriptif, penulis menemukan kepostmodernan gaya SGA yang melibatkan sekurang-kurangnya tujuh gaya postmodernisme, yakni fragmentasi, permainan bahasa yang sublim, pastiche, parodi, kitsch, camp, dan skizofrenia. Gaya fragmentasi terlihat pada gaya penggabungan sejumlah fragmen terpisah tentang rembulan sehingga menciptakan makna baru. Permainan bahasa yang sublim tampak pada permainan SGA mengubah sesuatu yang tidak mungkin menjadi mungkin. Gaya pastiche terlihat pada pengutipan puisi Pablo Neruda yang menceritakan singkatnya mencintai seseorang dan lamanya waktu yang dibutuhkan untuk melupakan seseorang. Gaya parodi terlihat pada penukaran rembulan dengan soto Betawi di restoran Italia. Gaya kitsch, Gaya camp muncul pada peniadaan nama-nama tokoh selayaknya cerpen kebanyakan. Gaya skizofrenia muncul pada pengisahan SGA mengenai rembulan yang dapat dijadikansebagai tanda atau simbol makna yangbergeser antara penanda danpetandanya. Ketika makna rembulan yang telah mapan mengacu pada 'benda langit yg mengitari bumi, bersinar pada malam hari karena pantulan sinar matahari' dan 'kecantikan malam', SGA menggeser maknanya sebagai sebuah beban melupakan seseorang.
\end{abstract}

Kata-kata kunci: stilistika sastra, cerpen, postmodern Lyotard, rembulan, capucino

\section{PENDAHULUAN}

Karya sastra terus berkembang dari zaman ke zaman. Perkembangan tersebut menjadikan kajian postmodernisme dalam karya sastra semakin menarik untuk dilakukan. Pemilihan cerpen "Rembulan dalam Capucino” (RdC) karya Seno Gumira Ajidarma (SGA) sebagai objek kajian dilatarbelakangi oleh uniknya gaya pengisahan SGA yang menjadikan cerpen ini 
menarik untuk dikaji melalui perspektif postmodernisme.

Cerpen "RdC" menceritakan seorang perempuan yang baru seminggu bercerai memasuki sebuah kafe dan memesan menu Rembulan dalam Cappuccino. Semenjak kafe itu berdiri sepuluh tahun lalu, baru kali ini ada yang memesan rembulan dalam cappuccino. Kafe itu memang menyediakannya dan minuman itu memang hanya bisa dipesan satu kali, karena rembulan memang hanya satu.Seminggu kemudian, seorang lelaki memasuki kafe yang sama, dan memesan minuman yang sama, "RdC". Pelayan menjawab minuman itu sudah tidak lagi ada dan seorang perempuan telah memesannya minggu lalu. Pelayan meyakinkan bahwa minuman telah dibeli dan tidakada lagi di dalam daftar menu, ia juga meyakinkan sudah tidak ada rembulan lagi dalam seminggu ini. Pelayan kemudian menceritakan bahwa perempuan tersebut tidak memakannya dan dia minta rembulan itu dibungkus setelah tidak menyentuhnya sama sekali, hanya memandanginya saja berjam-jam sambil mengusap air mata. Ketika si perempuan meminta rembulan itu dibungkus. Ketika dibungkus, rembulan sebesar bola pingpong yang semula terapung-apung di dalam cangkir itu berubah menjadi sebesar bola basket. Kepala dapur bereaksi dan meminta agar pencoretan "RdC" dari daftar menu ditunda. Ia mengatakan rembulan itu belum hilang dan ia berandai siapa tahu perempuan itu mengembalikannya.Lelaki itu berpesan kalau dia muncul lagi, ia juga mau rembulan itu.

Si perempuan berada di suatu tempat tanpa cahaya, kelam, begitu kelam, seperti ditenggelamkan malam. Ia teringat gambaran bagaimana ayahnya diambil dari rumahnya di tengah malam buta. Digelandang dan diarak sepanjang kota sebelum akhirnya disabet lehernya dengan celurit sehingga kepalanya menggelinding di jalanan dan darahnya menyembur ke atas seperti air mancur deras sekali sampai menciprati orang-orang yang mengarak ayahnya itu. Rembulan itu berada di punggungnya sekarang, terbungkus dan tersimpan dalam ranselnya. Ia ragu akan ia berikan kepada bekas suaminya atau dibuang saja rembulan itu ke sungai, seperti membuang suatu masalah agar pergi menjauh selamanya dan tidak pernah kembali? Dalam kegelapan tanpa rembulan, perempuan itu tidak bisa melihat senyuman maupun air matanya sendiri di permukaan sungai yang mengalir perlahan dan ia tak tahu apakah masih harus mengutip Pablo Neruda, Tonight I can write the saddest lines...Tiga minggu kemudian, si perempuan mengembalikan rembulan dan minta diganti soto Betawi.

Beberapa penelitian tentang cerpen SGA pernah dilakukan sebelumya. Beberapa di antaranya adalah penelitian yang dilakukan oleh Supena (2013) yang menyelidiki novel Kitab Omong Kosong karya SGA yang melihat repertoar strategistrategi pengedepanan sifat antologis postmodernisme. Pluralitasontologisme itu dikelompokkan kedalam beberapa kategori di antaranya,yaitu (1) dunia-dunia, (2) konstruksi, (3) kata-kata, dan (4) pendasaran. Persinggungan antara fiksipostmodernisme dengan fiksi fantasi melihat bahwa antara teks yang satudengan teks yang lain bisa saling melintas juga menjadi dasar bagi terjadinya persinggungan antara fiksipostmodenisme dan fiksi fantastik. Hal ini terjadi sebagaimana persinggungan antara fiksi postmodernis dan fiksi ilmiah, yang dominan pada kedua jenisfiksi tersebut adalah sifat ontologisnya. Selain itu, "Analisis Hegemoni pada cerpen Iblis Tidak Pernah Mati Karya Seno Gumira Ajidarma" juga pernah dilakukan oleh Nurhadi (2004) yang melihat formasi ideologi dalam masyarakat, dan hubungan historis Iblis Tidak Pernah Mati sebagai bagian dari negosiasi ideologi yang terjadi dalam masyarakat. Kemudian Swaratyagita (2005) pernah melakukan penelitianuntuk mengungkap bentuk hegemoni penguasa 
dalam novel Negeri Senja yang ditampilkan melalui simbol-simbol yang terdapat di dalam teks dengan menggunakan Semiologi Roland Barthes mengenai fashionsistem.

\section{LANDASAN TEORI}

Stilistika merupakan objek baik bagi ilmu linguistik maupun ilmu sastra. Perbedaanya stilistika linguistik terbatas pada penelitian gejala bahasa secara deskriptif, yang dalam perkembangan kemudian disebut sebagai majas, sedangkan stilistika sastra melangkah lebih jauh pada aspek-aspek yang melatarbelakangi sekaligus tujuan yang hendak dicapai, sebagai penelitian evaluatif. Menurut Wellek dan Warren (1990:227) untuk meneliti aspek-aspek stilistika karya seorang pengarang di samping memahami kaidahkaidah linguistiknya perlu juga menelusuri penggunaan bahasa pada zamannya, sebab pada dasarnya stilistika adalah perbedaan penggunaan karya sastra dengan penggunaan bahasa pada zaman tertentu.

Karya seni, termasuk sastra, yang bersifat imajinatif, personal, dan khas menjadi bagian dari struktur sosial. Oleh karena itu, sikap dan gaya merupakan representasi peranan-peranan sosial, baik sebagai manifestasi perilaku individual maupun komunitas tertentu (Ratna, 2007:251). Perubahan kultural direfleksikan melalui gaya bahasa, sedangkan gaya bahasa dipengaruhi oleh masyarakat.

Seluruh aspek kehidupan merupakan tanda, yang digunakan sebagai sistem komunikasi. Sebuah tanda akan bermakna jika digunakan dalam proses interaksi dan komunikasi. Bahasa merupakan salah satu sistem komunikasi terpenting sekaligus rumit dan kompleks. Karya seni, melalui mekanisme struktur sosial, mengubah struktur sosiokultural yang statis, stagnasi, dan beku, menjadi dinamis, bergerak, dan cair, yaitu melalui mode, cara, gaya, dan gaya bahasa (Ratna, 2007:252). Wellek dan Warren (1990:228) menegaskan bahwa stilistika sastra memiliki wilayah yang lebih kaya, baik dibandingkan dengan stilistikalinguistik maupun retorika.

Postmodern menurut Lyotard (dalam Faisal, R. 2010:396--414) merupakan suatu pemutusan hubungan total dengan budaya modern dan bukan sekadar koreksi atas berbagai pemikiran dan budaya modern. Postmodernisme diartikan sebagai ketidakpercayaan pada berbagai bentuk metanarasi, ketidakpercayaan pada klaim kebenaran ilmu pengetahuan objektifuniversal. Ketidakpercayaan pada klaim kebenaran objektif-universal itu didasarkan atas kesadaran akan adanya keterbatasan dan ketidakmampuan dalam melihat realitas dari perspektif dan primitiv tertentu. Penolakan terhadap metanarasi berarti berakhirnya penjelasan yang bersifat universal tentang tingkah laku dalam rasionalitas instrumental.

Postmodernisme menurut McHale (dalam Pujiharto, 2005:88--97) merupakan istilah yang tidak ada acuannya karena postmodernisme merupakan suatu konstruksi. Oleh sebab itu, terdapat beragam pengertian postmodernisme. Hal yang penting menurut McHale adalah bahwa konstruksi postmodernisme yang dibangun memiliki konsistensi dan koherensi internal, ruang lingkup yang tidak begitu luas dan tidak begitu sempit, dan produktif.

Endraswara (2013:167) mengutip pendapat Lyotarddalam bukunya The Postmodern Condition, postmodern telah menentang mitos-mitos modern, menghilangkan batas-batas antara seni dan kehidupan masa kini, antara elit yang hirarkhis dengan budaya populer, antara gabungan stilistik dengan percampuran kode, mengubah hal yang tak mungkin menjadi mungkin. Penulis meyakini "RdC" ini menarik dikajidengan menggunakan pisau postmodern Lyotard. Melalui cerpen ini Seno mencoba menentang mitos-mitos modern dan mengubah hal yangtak mungkin menjadi mungkin dengan menggunakan kata-kata yang digeserkan makna-maknanya bukan makna yang sebenarnya, seperti sifat perahu dan kupu-kupu yang sudah dipahami 
secara total telah difragmentasikan oleh Seno. Hal inilah yang diamati dan dianalisis dalam penelitian ini dengan masalah penelitian, bagaimanakah gaya penceritaan Seno Gumira Ajidarma dalam cerpen "RdC" ditinjau dari posmodernisme Lyotard? Selanjutnya, tujuan penelitian ini adalah mengungkap gaya penceritaan SGA dalam cerpen "RdC".

Ciri pertama stilistika postmodern Lyotard adalah fragmentasi. Dalam karyaseni organik, materi seni dipandang sebagai suatu keutuhan, sementara dalam karya seni garda depan, bahan seni dipisahkan dari totalitas hidup dan diisolasi. Fragmen garda depan estetik menantang orang untuk menjadikannya sebagai bagian integral realitas dan menghubungkannya dengan pengalaman mereka (Lyotard, 1984).

Stilistika postmodern memainkan permainan bahasa yang sublim. Sublim tidak hanya berhubungan dengan kepedihan, kekelaman, kesunyian, bahaya, kedalaman, kekosongan, tetapi juga kemegahan, kemahaluasan, ketakterhinggaan. Dibanding bahasa yang indah, sublim jauh lebih mampu membangkitkan emosi terkuat yang ada dalam diri seseorang yang melampaui semua pembatasan penilaian 'rasional' yang telah diatur. Stilistika postmodernisme melakukan yang sebaliknya: memandang sesuatu yang di anggap tidak benar oleh kebanyakan orang di angkat dan di dekonstruksi sehingga sesuatu yang dianggap tidak benar bisa menjadi sesuatu yang dimaklumi karena memandang sesuatu dari sudut pandang yang berbeda. Stilistika postmodern juga memandang sesuatu yang di anggap tidak benar oleh kebannyakan orang dan di dekonstruksi, sehingga sesuatu yang dianggap tidak benar bisa menjadi sesuatu yang dimaklumi karena memandang sesuatu dari sudut pandang yang berbeda (Lyotard, 1984).

Bagi Lyotard (Lyotard, 1984), permainan bahasa adalah ikatan sosial yang mempersatukan masyarakat, interaksi sosial terlihat terutama dalam pengertian pengambilan langkah dalam permainan, pengambilan peran tertentu, dan partisipasi dalam pelbagai macam permainan bahasa. Dalam pengertian tersebut, Lyotard melihat diri sebagai interaksi semua permainan bahasa yang diikuti.

Konsep permainan bahasa ini dilakukan dengan cara bahwa masing masing pernyataan dapat didefinisikan menurut aturan-aturan yang menentukan sifat dan nilai gunanya. Menurut Lyotard, permainan bahasa yang sublim telah membawa kita melampaui batas pemikiran di mana penilaian harus mengakui ketidakmemadaian sumber dayanya, atau ketiadaan kriteria yang disepakati bersama, untuk menghadapi kasus-kasus yang melampaui semua pembatasan penilaian 'rasional' yang telah diatur (Lyotard dalam Lubis, A.Y. 2014).

Gaya posmodern juga dapat kita temui dalam ranah sastra terlebih kita dapat memahami bahwa sastra adalah bagian dari seni. Dalam bukunya yang berjudul Hiperrealitas Kebudayaan: Semiotika, Estetika, Posmodernisme, Yasraf Amir Pilliang (1999:149) mengungkapkan pendapat Lyotard "paling tidak terdapat lima idiom yang cukup dominan mencirikan estetika posmodern, yaitu (1) pastiche, (2) parodi, (3) kitsch, (4) camp, dan (5) skizofrenia" (Lyotard dalam Pilliang, 1999:149). Kelima idiom yang diungkap oleh Lyotard (dalam Pilliang 1999) ini merupakan rangkuman dari berbagai ahli yang memiliki pandangan yang berbedabeda, satu diantaranya adalah Baldick. Piliang merangkum penjelasan para ahli sembari membubuhkan pendapatnya sendiri sehingga ia berhasil merumuskan kelima idiom tersebut sebagai ciri estetika postmodernisme. Ia menjelaskan "pastiche" sebagai pinjaman yang disusun dari elemenelemen yang dipinjam dari berbagai penulis lain, atau dari penulis tertentu di masa lalu (Lyotard dalam Pilliang, 1999:149). Karakteristik pastiche muncul ketika sebuah 
teks boleh jadi meniru atau mengimitasi karya sastra lain atau karya terdahulu.

Parodi merupakan komposisi dalam prosa yang di dalamnya kecenderungankecenderungan demikiran dan ungkapan karakteristik dalam diri seorang pengarang atau kelompok pengarang diimitasi sedemikian rupa untuk membuatnya tampak absurd, khususnya dengan melibatkan subjek-subjek lucu dan janggal, imitasi dari sebuah karya yang dibuat modelnya kurang lebih mendekati aslinya, tetapi disimpangkan arahnya sehingga menghasilkan efek-efek kelucuan (Lyotard dalam Pilliang, 1999:153).

Camp merupakan bentuk seni yang menekankan dekorasi, tekstur, permukaan sensual dan gaya dengan mengorbankan isi. Pada karya camp objek-objek alam, manusia, dan binatang seringkali digunakan, namun secara ekstrem dideformasikan, misalnya dengan dibuat lebih kurus, ramping, jangkung, gendut, besar, dan lebar (Lyotard dalam Pilliang, 1999:163). Camp diciptakan sebagai satu jawaban terhadap "kebosanan" dan sekaligus merupakan satu reaksi terhadap keangkukan kebudayaan tinggi yang telah memisahkan seni dari makna-makna sosial dan fungsi komunikasi sosial. Camp selalu melibatkan unsur duplikasi dan menggunakan manerisme, seperti bulu mata yang dilentikkan, senyum rahasia, jas yang berjumbai, yang mengundang penafsiran ganda (Lyotard dalam Pilliang, 1999:165). Skizofrenia pada awalnya merupakan sebuah istilah psikoanalisis, yang pada awalnya digunakan untuk menjelaskan fenomena psikis dalam diri manusia. Kini istilah tersebut digunakan secara metaforik untuk menjelaskan fenomena yang lebih luas, termasuk di antaranya fenomena bahasa, sosial-ekonomi, sosial-politik, dan estetika. Dalam kebudayaan dan seni, skizofrenia digunakan sebagai metafora untuk menggambarkan kesimpangsiuran penggunaan bahasa. Kekacauan pertandaan terdapat pada gambar, teks, objek, dan bahkan kalimat
(Lyotard dalam Pilliang, 1999: 167). Dalam karya seni, karya skizofrenik dapat dilihat dari keterputusan dialog di antara elemenelemen dalam karya, yaitu tidak berkaitannya elemen-elemen tersebut satu sama lain, sehingga makna karya tersebut sulit untuk ditafsirkan. Menurut Kamus Besar bahasa Indonesia, skizofrenia bermakna "penyakit jiwa yang ditandai oleh ketidakacuhan, halusinasi, waham untuk menghukum, dan merasa berkuasa, tetapi daya pikir tidak berkurang" (https://kbbi. kemdikbud. go. id/entri/skizofrenia). Ciri "ketidakacuhan" inilah yang menjadi karakteristik pendukung skizofrenia yang melepaskan hubungan antar unsur dalam sebuah karya. Skizofrenia inilah yang juga disebut sebagai pergeseran penanda dan petanda.

Masalah yang dirumuskan penulis dalam penelitian ini adalah bagaimanakah gaya penceritaan SGA dalam "RdC" diltinjau dari postmodernisme Lyotard. Penelitian ini bertujuan mengungkap gaya tersebut. Penulis berharap penelitian ini dapat memberikan kontribusi dalam kajian stilistika sastra khususnya dalam ranah kajian postmodernisme.

\section{METODE PENELITIAN}

Data yang digunakan dalam penelitian ini adalah data primer dan datasekunder. Data primer adalah cerpen "RdC" karya Seno Gumira Ajidarma (dalam Kompas edisi Minggu 31 Agustus 2003), sedangkan data sekunder berupa buku-buku dan penelitian ilmiah yang berhubungan dengan permasalahan. Secara keseluruhan, penelitian ini tergolong penelitian deskriptif dengan menggunakan metode kualitatif. Metode kualitatif adalah prosedur penelitian yang berdasarkan danmenghasilkan datadata deskriptif berupa data tertulis (Bogdan dan Taylor dalam Meleong, 1995:3). Menurut Nawawi (2007:66) data kualitatif ini adalah data yang hanya dapat diukursecara tidak langsung. Data ini hanyadapat diamati atau diselidiki dengan 
menggunakan teori yang sesuai dengan permasalahan.

Dalam analisis data, penelitian ini menggunakan kajian stilistika postmodernisme Cara kerjateori postmodern Lyotard ini dimulai dengan melakukan analisis mengamati fragmentasi, permainan bahasa sublim, penggunaan pastiche, parodi, kitsch, camp dan skizofrenia yang memungkinkan makna bergeser dari penanda ke petanda.

\section{PEMBAHASAN}

\section{Fragmentasi}

Lyotard

menjelaskanbagaimana postmodernisme mencabut suatu elemen dari totalitaskonteks kehidupan, mengisolasi, danmencabut dari fungsinya.Selanjutnya, postmodernis menggabung-gabungkan sejumlahfragmen yang saling terisolasi,sehingga menciptakan makna. Makna yang dihasilkan tidakberasal dari konteks awal fragmen-fragmen tersebut.

Pada awal cerita, SGA menampilkan fragmentasi kehidupan modern dengan munculnya atau maraknya restoran Italia atau kafe-kafe yang menyediakan makanan atau minuman yang tentu saja menawarkan nama-nama menu asing.

Seminggu setelah perceraiannya, perempuan itu memasuki sebuah kafe, dan memesan Rembulan dalam Cappuccino. Ia datang bersama senja, dan ia harus menunggu malam tiba untuk mendapatkan pesanannya. (Ajidarma, Seno G. 2003 Paragraf ke-1)

Cappuccino $^{1}$ dalam lautan berwarna coklat, datang langsung dari tercemplung cangkir, tenggelam sebentar, tapi lantas pingpong-tapi bukan bola pingpong, ini rembulan... (Ajidarma, Seno G. 2003 Paragraf ke-2)

Kehidupan perkotaan sebagai satu fragmen menceritakan kebiasaan orangorang kota berkunjung ke kafe dan memesan makanan atau minuman. SGA menandai fragmen ini dengan pengenalan minuman capucino. Bahkan, ia melengkapi narasinya dengan catatan kaki untuk menjelaskan jenis minuman ini.

Kopi tradisional Italia, biasanya untuk sarapan-kopi espresso yang dibubuhi susu panas dan buih, sering juga ditaburi cokelat, dalam seduhan air panas 80 derajat celsius, dihidangkan dengan cangkir. (Sumber: dari bungkus gula nonkalori Equal).

Selanjutnya, SGA membawa tokohtokoh tanpa nama dalam cerpen "RdC" untuk dapat ditafsirkan sebagai tokoh yang perannya tidak untuk menginterpretasi atau mencocokan kedalam dunia yang di dalamnya ternyata mereka sendiri hidup, tetapi justru untuk menunjukan eksistensi dari suatu pluralitas. Fragmen kedua ia perkenalkan sehingga tokoh perempuan seakan berada di dunia yang terombangambing antara dendam akan zaman kegelapan saat pembantaian G30S/PKI, seperti dalam kutipan berikut.

Dia berada di suatu tempat tanpa cahaya, kelam, begitu kelam, seperti ditenggelamkan malam, sehingga bintangbintang yang bertaburan tampak jelas, terlalu jelas, seperti peta dengan namanama kota. Perempuan itu belum lupa, apalah artinya nasib satu manusia di tengah semesta, nasib yang sebetulnya jamak pula dialami siapa pun jua di muka bumi yang sebesar merica.Namun, ia merasa bagaikan kiamat sudah tiba. Agak malu juga sebetulnya.

Banyak orang lain harus hidup dengan gambaran bagaimana ayahnya diambil dari rumahnya di tengah malam buta. Digelandang dan diarak sepanjang kota sebelum akhirnya disabet lehernya dengan celurit sehingga kepalanya menggelinding di jalanan dan darahnya menyembur ke atas seperti air mancur deras sekali sampai menciprati orang-orang yang mengaraknya itu. Tidak sedikit orang yang hidup dengan kutukan betapa ibunya telah menjadi setan jalang yang 
memotong-motong alat kelamin lelaki sambil menyanyi dan menari, dan karena itu berhak disiksa dan diperkosa, padahal semua itu merupakan kebohongan terbesar di muka bumi. Hidup ini bisa begitu buruk bagi orang baik-baik meskipuntidak mempunyaikesalahan samasekali. Tanpa pembelaan sama sekali. ${ }^{2}$ Tanpa pembelaan. Tanpa...

(Ajidarma, Seno G. 2003 paragraf 12)

SGA memperkuat fragmennya dengan menyertakan catatan kaki pada penghujung cerpen "RdC" sebagai berikut.

Tentang penyiksaan sesama manusia Indonesia, bisa dilacak dalam sejumlah dokumen, antara lain, Pipit Rochijat, "Am I PKI or Non PKI?" dalam Indonesia edisi 40 (Oktober 1985); A Latief, Pleidoi Kol. A. Latief: Soeharto Terlibat G $30 \mathrm{~S}$ (2000); Sulami, Perempuan-Kebenaran dan Penjara (1999); Sudjinah, Terempas Gelombang Pasang (2003), dan tentu saja Pramoedya Ananta Toer, Nyanyi Tunggal Seorang Bisu (1995).

Fragmentasi

postmodernisme menyebabkan karya sastra cenderung memiliki beberapa sudut pandang dari tokoh yang ada didalam cerita, terdapat istilah wacana dalam wacana. Sudut pandang si perempuan dan si pria tentang rembulan. Karakteristik tersebut ditemukan dalam cerpen "RdC" yang berbeda dengan alur prosa modern. Di dalam cerpen ini setidaknyaditemukan mitos-mitos yang cobadiangkat dan dipercaya oleh banyakorang.

\section{Permainan Bahasa dan Yang Sublim}

Konsep "bahasa yang sublim" menurut Lyotard (1984) adalah bahasa yang melampaui semua kekuatan representasi kita, pengalaman yang tidak dapat dinyatakan dengan mode pemahaman konseptual atau indrawi secara memadai, dan yang berbeda dengan yang indah sejauh tidak menghasilkan keseimbangan atau kesesuaian yang harmonis antara kedua kemampuan tersebut. Selain itu yangsublim merupakan sarana menyatakan(dengan analogi) apa yang sama sekalitidak dapat diungkapkan. SGA di dalam cerpen "RdC" ini menyertakan banyak hal yangdapat dikategorikan yang sublim. Konsep permainan bahasa iniditemukan dalam cerpen, dimulai darikonsep "rembulan". Rembulan selama ini bermakna "benda langit yang mengitari bumi, bersinar pada malam hari karena pantulan sinar matahari' telah dimainkan oleh SGA sebagai bagian dari menu minuman yang terapung dalam minuman capucino. Rembulan tersebut "menghilang" dari langit segera setelah dipesan oleh si perempuan, seperti dalam kutipan paragraf ke-4, ke-5, dan ke-6 berikut.

"Rembulan dalam Cappuccino, satu!" Teriak pelayan ke dapur, dan kepala bagian dapur memijit-mijit nomor hp, seolah-olah ada persiapan khusus.

"Akhirnya tiba juga pesanan ini," katanya, "aku sudah bosan melihatnya di daftar menu tanpa pernah ada yang pesan."

Kepala dapur itu bicara dengan entah siapa melalui hp.

"Iyalah, turunin aja, sudah tidak ada lagi yang membutuhkan rembulan."

(Ajidarma, Seno G. 2003 paragraf 4)

Perempuan itu bukan tidak tahu kalau orang-orang memperhatikannya. Apakah perempuan itu akan memakan rembulan itu, menyendoknya sedikit demi sedikit seperti menyendok es krim, ataukah akan menelannya begitu saja seperti Dewa Waktu menelan matahari? (Ajidarma, Seno G. 2003 paragraf 5)

Ia memperhatikan rembulan yang terapung-apung di cangkirnya, permukaan cappuccino masih dipenuhi busa putih, seperti pemandangan Kutub Utara-tapi cappuccino itu panas, bagaikan masih mendidih. Ia senang dengan penampakan itu, dingin tapi panas, panas tapi dingin, segala sesuatu tidak selalu seperti 
tampaknya. (Ajidarma, Seno G. 2003 paragraf 6)

Menu minuman "rembulan dalam capucino" yang hanya disediakan sekali telah dipesan oleh si perempuan. Rembulan tersebut dapat terapung-apung dalam secangkir capucino yang ia pesan. Dalam hal ini, permainan bahasa sublim SGA telah mengubah sesuatu yang tidak mungkin menjadi mungkin. Hal ini diperkuat oleh narasi SGA pada paragraf ke-7 dan ke-8 yang mengungkapkan kedatangan seorang pria (mantan suami si perempuan) yang memesan menu yang sama. Pelayan menjawab bahwa menu tersebut telah dipesan mantan istrinya minggu lalu dan ia meyakinkan si pria untuk melihat rembulan yang telah hilang dari langit.

Seminggu kemudian, seorang lelaki memasuki kafe itu, dan memesan minuman yang sama

...

"Apakah Tuan tidak memperhatikan, sudah tidak ada rembulan lagi dalam seminggu ini?"

Lelaki itu tersentak.

"Seorang perempuan? Istri saya? Eh, maaf, bekas istri saya?"

Para pelayan saling berpandangan. Salah seorang pelayan menjelaskan ciri-ciri perempuan yang telah memesan Rembulan dalam Cappuccino itu.

"Ah, pasti dia! Dasar! Apa sih yang tidak ingin ditelannya dari dunia ini? Apakah dia makan rembulan itu?"

Para pelayan saling berpandangan lagi.

(Ajidarma, Seno G. 2003 paragraf ke-7)

Kemudian dia meminta rembulan itu dibungkus. Ketika dibungkus, rembulan sebesar bola pingpong yang semula terapung-apung di dalam cangkir itu berubah menjadi sebesar bola basket.

(Ajidarma, Seno G. 2003 paragraf ke-7)

SGA telah menjadikan sesuatu yang tidak mungkin menjadi mungkin dengan mengungkap beberapa hal. Pertama, restoran Italia memasang menu satu kali saja dan setelah dipesan menu akan dihapus. Kedua, rembulan dapat disajikan terapung di permukaan minuman capucino di dalam cangkir. Ketiga, rembulan di langit menghilang dan berpindah di atas capucino. Keempat, minuman "rembulan dalam capucino" dapat dibungkus untuk dibawa pulang si perempuan. Keenam, rembulan sebesar bola pingpong yang semula terapung-apung di dalam cangkir itu berubah menjadi sebesar bola basket.

Permainan bahasa yangsublim, yang memperlihatkan petunjukadanya heterogenitas radikal dalamwacana kebenaran dan nilai. Permainanbahasa yang sublim ini telah membawakita melampaui batas pemikiran dimana penilaian harus mengakuiketidakmemadainya sumber daya, atauketiadaan kriteria yang disepakatibersama, untuk menghadapi kasus-kasus yang melampaui semuapembatasan penilaian 'rasional' (Lyotard, Jean Francois. 1984 hlm 82). Permainan bahasa ini berlanjut ketika rembulan dapat menempel di punggung si perempuan dan terus menghilang dari langit malam sehingga malam terus gelap tanpa kehadiran rembulan, seperti pada kutipan paragraf ke-14 berikut.

Rembulan itu berada di punggungnya sekarang, terbungkus dan tersimpan dalam ransel-apakah ia berikan saja kepada bekas suaminya, yang diketahuinya selalu bercita-cita memesan Rembulan dalam Cappuccino? Kalau mau kan banyak cappuccino instant di lemari dapur (ia lebih tahu tempat itu daripada suaminya) dan meski rembulan di punggungnya sekarang sebesar bola basket, nanti kalau mau dimasukkan cangkir akan menyesuaikan diri menjadi sebesar bola pingpong. ... (Op Cit Ajidarma. 2003 paragraf ke-14)

\section{Pastiche}


Gejala atau kecenderungan posmodern lain juga dapat kita temui dalam cerpen "RdC". Ia menjelaskan "pastiche" sebagai pinjaman yang disusun dari elemen-elemen yang dipinjam dari berbagai penulis lain, atau dari penulis tertentu di masa lalu (Lyotard, Jean Francois. 1984:149). Karakteristik pastiche muncul ketika sebuah teks boleh jadi meniru atau mengimitasi karya sastra lain atau karya terdahulu. Pastiche didefinisikan sebagai karya sastra yang disusun dari elemen-elemen yang dipinjam dari berbagai penulis lain, atau penis lain di masa lalu. Fenomena pasticheditemukan dalam paragraf ke-4 "RdC".

Dalam kegelapan tanpa rembulan, perempuan itu tidak bisa melihat senyuman maupun air matanya sendiri di permukaan sungai yang mengalir perlahan- dan ia tak tahu apakah masih harus mengutip Pablo Neruda.

Tonight I can write the saddest lines...

(Ajidarma, Seno G. 2003 paragraf ke-14)

Elemen yang dipinjam SGA dari Pablo Neruda berfungsi sebagai pembangun suasana hati si perempuan. Dia dan bekas suaminya sama-sama tahu betul mengenai rembulan itu, ia bahkan sempat berpikir untuk membuang rembulan itu ke sungai, seperti membuang suatu masalah agar pergi menjauh selamanya dan tidak pernah kembali. Ia kemudian merasa bahwa ia yang mewajibkan dirinya berduka, karena selayaknyalah seorang istri yang diceraikan dengan semena-mena merasa terbuang, padahal perpisahan itu membuat peluangnya untuk bahagia terbuka luas.

Tonight I can write the saddest lines.

Pablo Neruda.

Write, for example,'The night is shattered and the blue stars shiver in the distance.'

The night wind revolves in the sky and sings.

Tonight I can write the saddest lines.
Tonight I can write the saddest lines.

To think that I do not have her. To feel that I have lost her.

To hear the immense night, still more immense without her.

And the verse falls to the soul like dew to the pasture.

What does it matter that my love could not keep her.

The night is shattered and she is not with me.

This is all. In the distance someone is singing. In the distance.

My soul is not satisfied that it has lost her.

My sight searches for her as though to go to her.

My heart looks for her, and she is not with me.

The same night whitening the same trees.

$\mathrm{We}$, of that time, are no longer the same.

I no longer love her, that's certain, but how I loved her.

My voice tried to find the wind to touch her hearing.

Another's. She will be another's. Like my kisses before.

Her voide. Her bright body. Her inifinite eyes.

I no longer love her, that's certain, but maybe I love her.

Love is so short, forgetting is so long.

Because through nights like this one I held her in my arms

my sould is not satisfied that it has lost her.

Though this be the last pain that she makes me suffer

and these the last verses that I write for her.

Pablo Neruda ini merupakan bagian dari gaya postmodernisme, yakni pastiche atau pinjaman dari karya lain. SGA juga menyertakan catatan kaki yang menerangkan puisi karya Pablo Neruda ini dalam paragraf kutipan atau paragraf ke-16. Puisi "Tonight I Can Write" ini bersumber pada puisi berbahasa Spanyol "Puedo Escribir" dalam 20 Puemas de amor y una Cancion desesperada (Twenty Love Poems and a 
Song of Despair) karya Pablo Neruda pada tahun 1924, terjemahan ke dalam bahasa Inggris oleh WS Merwin, terbit pertama kali tahun 1969.Puisi karya Pablo Neruda tersebut menceritakan kesedihan seseorang yang berpisah dengan pujaan hatinya. Perpisahan yang diakibatkan hilangnya rasa cinta dan keyakinan pujaan hati akan menjadi milik orang lain (I no longer love her, that's certain, but how I loved her. My voice tried to find the wind to touch her hearing. Another's. She will be another's). Puisi Pablo ini juga menegaskan bahwa mencintai seseorang sangatlah singkat tetapi melupakan seseorang adalah proses yang berkepanjangan, seperti beban rembulan yang dibawa oleh si perempuan. Adalah sebuah pilihan, apakah si perempuan terus akan bergundah gulana menggendong rembulan di punggungnya (beban) atau melepaskan diri dari kesedihan dan memilih untuk menggapai kebahagiaan yang luas terbentang di depannya dengan mengembalikan rembulan ke rumah makan Italia.

\section{Parodi}

Parodi merupakan komposisi dalam prosa atau puisi yang di dalamnya kecenderungankecenderungan pemikiran dan ungkapan karakteristik dalam diri seorang pengarang diimitasi sedemikian rupa untuk membuatnya tampak absurd, khususnya dengan melibatkan subjek-subjek lucu dan janggal, dan disimpangkan arahnya sehingga menghasilkan efek-efek kelucuan.

Tiga minggu kemudian, pada hari hujan yang pertama musim ini, perempuan itu muncul lagi di kafe tersebut.

"Saya kembalikan rembulan ini, bisa diganti soto Betawi?"

Itulah masalahnya.

"Tidak bisa Puan, kami tidak punya soto

Betawi, ini kan restoran Itali?

SGA menampilkan parodi di penghujung cerita. Si perempuan pada akhirnya memutuskan mengembalikan rembulan yang sudah ia beli ke rumah makan Italia. Ia meminta penukaran rembulan dengan soto betawi, sebuah parodi yang menarik di akhir cerita SGA.

\section{Camp}

Campmerupakan bentuk seni yang menekankan dekorasi, tekstur, permukaan sensual dan gaya dengan mengorbankan isi. Pada karya camp objek-objek alam, manusia, dan binatang seringkali digunakan, namun secara ekstrem dideformasikan, misalnya dengan dibuat lebih kurus, ramping, jangkung, gendut, besar, dan lebar (Pilliang, 1999: 163). Camp diciptakan sebagai satu jawaban terhadap "kebosanan" dan sekaligus merupakan satu reaksi terhadap keangkukan kebudayaan tinggi yang telah memisahkan seni dari maknamakna sosial dan fungsi komunikasi sosial. Camp selalu melibatkan unsur duplikasi dan menggunakan manerisme, seperti bulu mata yang dilentikkan, senyum rahasia, jas yang berjumbai, yang mengundang penafsiran ganda.

Cerpen "RdC" menampilkan tokohtokoh tanpa nama. Dalam cerpen tersebut pengarang sengaja menggunakan gaya penceritaan yang baru di tengah konvensi prosa yang telah ada. Bentuk semacam ini menunjukan kebebasan pengarangnya dalam mengekspresikan ide dan gagasannya yang tidak mau lagi dibatasi dengan adanya bentuk-bentuk atau konvensi, batasanbatasan atau aturan-aturan penulisan cerpen yang selama ini diikuti oleh pengarang cerpen yang lainnya. Tokoh perempuan, laki-laki, pelayan, kepala dapur, pun ayah si wanita tidak ada yang diberi nama. Gaya penceritaan SGA tersebut masuk dalam gaya posmodernisme yang berjenis camp.Camp adalah bentuk seni yang menekankan dekorasi, tekstur, permukaan sensual dan gaya dengan mengorbankan isi. Camp diciptakan sebagai satu jawaban terhadap kebosanan sekaligus merupakan satu reaksi terhadap keangkuhan kebudayaan tinggi yang telah memisahkan makna-makn sosial 
dan fungsi komunikasi sosial, seperti dalam kutipan-kutipan berikut.

Seminggu setelah perceraiannya, perempuan itu memasuki sebuah kafe, dan memesan Rembulan dalam Cappuccino. Ia datang bersama senja, dan ia harus menunggu malam tiba untuk mendapatkan pesanannya. (Ajidarma, Seno G. 2003 paragraf 1)

"Rembulan dalam Cappuccino, satu!" Teriak pelayan ke dapur, dan kepala bagian dapur memijit-mijit nomor $\mathrm{hp}$, seolah-olah ada persiapan khusus.

“Akhirnya tiba juga pesanan ini," katanya, "aku sudah bosan melihatnya di daftar menu tanpa pernah ada yang pesan."

Kepala dapur itu bicara dengan entah siapa melalui hp.

"Iyalah, turunin aja, sudah tidak ada lagi yang membutuhkan rembulan."

(Ajidarma, Seno G. 2003 paragraf 4)

Seminggu kemudian, seorang lelaki memasuki kafe itu, dan memesan minuman yang sama.

"Rembulan dalam Cappuccino," katanya.

Para pelayan saling berpandangan.

"Oh, minuman itu sudah tidak lagi ada

Tuan, seorang perempuan telah memesannya minggu lalu."

Lelaki itu terpana.

"Apakah Tuan tidak memperhatikan, sudah tidak ada rembulan lagi dalam seminggu ini?"

Lelaki itu tersentak.

"Seorang perempuan? Istri saya? Eh, maaf, bekas istri saya?"

Para pelayan saling berpandangan. Salah seorang pelayan menjelaskan ciri-ciri perempuan yang telah memesan Rembulan dalam Cappuccino itu.

"Ah, pasti dia! Dasar! Apa sih yang tidak ingin ditelannya dari dunia ini? Apakah dia makan rembulan itu?"

Para pelayan saling berpandangan lagi.

"Tidak Tuan..."

"Jadi?"

"Kalau memang perempuan itu istri Tuan..."
"Bekas...."

"Maaf, bekas istri Tuan, mungkin Tuan masih bisa mendapatkan rembulan itu."

"Maksudmu?"

"Dia tidak memakannya Tuan, dia minta rembulan itu dibungkus."

"Dibungkus?"

"Ya Tuan, ia tidak menyentuhnya sama sekali, hanya memandanginya saja berjam-jam."

(Ajidarma, Seno G. 2003 paragraf 7)

Tokoh tanpa nama dalam sebuah prosa sangat jarang dijumpai. Seluruh tokoh dalam "RdC" tidak diberi nama oleh SGA menunjukkan gaya perlawanan terhadap "narasi besar" dalam prosa Indonesia.

\section{Skizofrenia}

SGA menggunakan skizofrenia digunakan sebagai metafora untuk menggambarkan kesimpangsiuran penggunaan bahasa. Kekacauan pertandaan atau pergeseran penanda dan petanda terdapat pada penggambaran rembulan dan capucino.

Cappuccino dalam lautan berwarna coklat, datang langsung dari tercemplung cangkir, tenggelam sebentar, tapi lantas pingpongtapi bukan bola pingpong, ini rembulan. Semua orang berada dalam kafe diamdiam melangkah keluar, menengok ke langit, ingin membuktikan dengan mata kepala sendiri bahwa terapung-apung cangkir perempuan sebenarnya, seperti telah pelajari semenjak di sekolah dasar, yakni yang tiada pernah mereka saksikan sisi gelapnya, dan rembulan itu memang sudah tidak ada. Paragraf ke-2)

Di dalam "RdC" SGA memutus dialog di antara elemen-elemen dalam cerita, yaitu tidak berkaitannya elemen-elemen tersebut satu sama lain, sehingga makna karya tersebut sulit untuk ditafsirkan. Ciri "ketidakacuhan" inilah yang menjadi karakteristik pendukung skizofrenia yang melepaskan hubungan antar unsur dalam sebuah karya. Skizofrenia inilah yang juga disebut sebagai pergeseran penanda dan 
petanda. Capucino adalah kopi tradisional Italia, biasanya untuk sarapan-kopi espresso yang dibubuhi susu panas dan buih, sering juga ditaburi cokelat, dalam seduhan air panas 80 derajat celsius, dihidangkan dengan cangkir. Rembulan adalah 'benda langit yg mengitari bumi, bersinar pada malam hari karena pantulan sinar matahari'. Oleh SGA, konsep penanda rembulan dancapucino yang terdapat dalam cerpenini bergeser dari makna referensinya.Hal ini dikarenakan rembulan dalam cerpen tersebut tidakseperti rembulan yang secara umum telahdiketahui sebagai salah satu bagian tata surya. Pun capucino dalam cerpen tersebut hanya sebagaisebuah entertainer yang memunculkanfenomena dan menghibur orang.

SGA menggeser makna rembulan menjadi sebuah beban yang terus menempel pada punggung si wanita dan menjadikan malam-malamnya benar-benar gelap setelah perceraian dengan suaminya. Dia sebenarnya tahu mengenai rembulan itu, ia bahkan sempat berpikir untuk membuang rembulan itu ke sungai, seperti membuang suatu masalah agar pergi menjauh selamanya dan tidak pernah kembali. Ia kemudian merasa bahwa ia yang mewajibkan dirinya berduka, karena selayaknyalah seorang istri yang diceraikan dengan semena-mena merasa terbuang, padahal perpisahan itu membuat peluangnya untuk bahagia terbuka luas.

sekarang ia berada di sebuah jembatan dan sedang berpikir, apakah akan dibuangnya saja rembulan itu ke sungai, seperti membuang suatu masalah agar pergi menjauh selamanya dan tidak pernah kembali? Setiap orang mempunyai peluang bernasib malang, kenapa dirinya harus menjadi perkecualian? Ia seperti sedang mencurigai dirinya sendiri, janganjangan ia hanya mewajibkan dirinya berduka, karena selayaknyalah seorang istri yang diceraikan dengan semena-mena merasa terbuang, padahal perpisahan itu membuat peluangnya untuk bahagia terbuka seluas semesta...(Op Cit Ajidarma. 2003. Paragraf ke-14)

Tiga minggu kemudian, pada hari hujan yang pertama musim ini, perempuan itu muncul lagi di kafe tersebut.

"Saya kembalikan rembulan ini, bisa diganti soto Betawi?"

(Op Cit Ajidarma. 2003. Paragraf ke-15)

Fenomena di atas mencerminkan kesimpangsiuran penggunaan bahasa. Lyotard memandang bahwa, di dalam bahasa tidak ada keutuhan, yang ada hanyalah pulau-pulau bahasa, yang masingmasing diatur oleh sebuah system aturan yang tak bisa diterjemah kan ke dalam sistem yang lain. Ketika makna rembulan yang telah mapan mengacu pada 'benda langit yg mengitari bumi, bersinar pd malam hari karena pantulan sinar matahari' dan 'kecantikan malam', SGA menggeser maknanya sebagai sebuah beban hidup. Secara tersirat, SGA mengusung anti kemapanan, tidak percaya lagi pada sesuatu yang telah menjadi pakem atau ketetapan bersama.

\section{PENUTUP}

Dari pembahasan di atas dapatdisimpulkan bahwa cerpen "RdC" karya SGA merupakan salahsatu cerpen yang bergaya posmodernisme Lyotard. Kepostmodernan cerpen initerletak pada gaya pengisahan SGA yang melibatkan sekurang-kurangnya tujuh stilistika postmodernisme, yakni fragmentasi, permainan bahasayang sublim, pastiche, parodi, kitsch, camp, dan skizofrenia.

Gaya fragmentasi terlihat pada gaya penggabungan sejumlahfragmen terpisah tentang rembulan sehingga menciptakan makna baru. Permainan bahasayang sublim tampak pada permainan SGA mengubah sesuatu yang tidak mungkin menjadi mungkin. Gaya pastiche terlihat pada pengutipan puisi Pablo Neruda yang menceritakan singkatnya mencintai seseorang dan lamanya waktu yang 
dibutuhkan untuk melupakan seseorang. Gaya parodi terlihat pada penukaran rembulan dengan soto Betawi di restoran Italia. Gaya camp muncul pada peniadaan nama-nama tokoh selayaknya cerpen kebanyakan. Gaya skizofrenia muncul pada pengisahan SGA mengenai rembulan yang dapat dijadikansebagai tanda atau simbol makna yangbergeser antara penanda danpetandanya. Ketika makna rembulan yang telah mapan mengacu pada 'benda langit yg mengitari bumi, bersinar pd malam hari krn pantulan sinar matahari' dan 'kecantikan malam', SGA menggeser maknanya sebagai sebuah beban melupakan seseorang.

\section{DAFTAR PUSTAKA}

Ajidarma, Seno G. 2003. "Rembulan dalam Capucino" cerpen Harian Kompas edisi Minggu 31 Agustus 2003 paragraf 1 s.d 16.

Faisal, R. 2010. Kajian Postmodernisme pada Cerpen "Maryamah Karpov" Karya Andrea Hirata. Jurnal Artikulasi, 7(1), 396-414.

Hariyanto. 2004. Fenomena Parolklan Televisi Indonesia. Dalam Jurnal Bahasa dan Seni, 32(1), 112-126.

Lubis, A.Y. 2014. Postmodernisme:Teori dan Metode. Jakarta:RajaGrafindo Persada.

Lyotard, Jean Francois. 1984. The Postmodern Condition: A Report On Knoeledge. Diterjemahkan dari bahasa
Perancis oleh Geoff Bennington dan Brian Massumi. Manchester: Manchester University Press

Meleong, L. J. 2002. MetodePenelitian Kualitatif. Bandung:Remaja Rosda Karya.

Nawawi, H. 2007. Metode Penelitian Bidang Sosial. Yogyakarta:Gadjah Mada University Press.

Nurhadi. 2004. "Analisis Hegemonipada Iblis Tidak Pernah Matikarya Seno Gumira Ajidarma”.Tesis. Yogyakarta: Program Studillmu Sastra Program Pascasarjana Universitas Gadjah Mada.

Piliang, Y. A. 2003. Hipersemiotika:Tafsir Cultural Studies atas "Matinya Makna”. Bandung:Jalasutra.

Pujiharto. 2005. Konstruksi Postmodern dalam Cerpen Larung". Litera, 4, 8897.

Ratna, N. K. 2010. Metode Penelitian Sastra. Yogyakara: Pustaka Pelajar.

Supena, A. 2013. "PuitikaPostmodernisme dalam Novel Kitab Omong Kosong" karyaSeno Gumira Ajidarma. Tesis.Yogyakarta: Program Studi IlmuSastra Program PascasarjanaUniversitas Gadjah Mada. Swaratyagita, G. 2005. "RomanNegeri Senja karya Seno Gumira Ajidarma: Dari Simbolisasi Hingga Hegemoni”.Tesis. Program Pascasarjana Universitas Airlangga. 



\begin{tabular}{|lll|}
\hline \multicolumn{3}{|c|}{ TOTOBUANG } \\
\hline Volume 6 & Nomor 1, Juni 2018 & Halaman 47-58 \\
\hline
\end{tabular}

\title{
KONSTRUKSI SOSIAL PEPATAH TRADISIONAL DAN ATURAN ADAT UNTUK KESEIMBANGAN EKOLOGI \\ (Social Construction of Traditional Proverb and Customary Law For Balancing Ecology)
}

\author{
Dina Amalia Susamto \\ Badan Pengembangan dan Pembinaan Bahasa \\ Jalan Daksinapati Barat IV, Rawamangun Jakarta Timur \\ Pos-el: dina.susamto@gmail.com
}

(Diterima: 28 Mei 2018; Direvisi 30 Mei 2018; Disetujui: 5 Juni 2018)

\begin{abstract}
Traditional proverb is a language expression that is used as a tool to legitimize knowledge in a society. Lombok people have local knowledge that came from proverb and customary law that solved the ecology's problem that increase today. Language ass traditional proverbs and customary law are used as the tools to construct people's thought toward social awareness through internalization. The study aimed to analyze the proverb and costumary law which has used as the tools to construct social awareness. The study also discussed about kinds of traditional proverbs and customary law and their appearance, how the social contruction which related to ecology could construct people's awareness in west Nusa Tenggara through proverbs and customary law, and how individual and society practiced their culture, such as keeping ecology, after internalizing the values. . The results showed that the change of social structure that caused by the change of dinamical power had contributed to knowledge and people's awareness of the environment. Language was the representative of the symbolical legitimation of the law which was expressed in traditional proverbs and custamry law. These proverbs and customary law are used to construct people's awareness from generation to generation through internalizing the values..
\end{abstract}

Keywords: Traditional Proverb and Custamary Law, social Construction, ecology

\begin{abstract}
Abstrak
Pepatah tradisional merupakan ekspresi berbahasa yang menjadi sarana dalam legitimasi pengetahuan masyarakat. Masyarakat Lombok memiliki pengetahuan lokal yang berasal dari pepatah tradisional dan hukum adat yang dapat mengatasi masalah-masalah ekologi yang kini semakin meningkat. Bahasa dalam ungkapan tradisional dan hukum adat digunakan sebagai alat untuk mengonstruksi pola pikir masyarakat terhadap kesadaran sosial melalui proses internalisasi. Penelitian ini bertujuan untuk menganalisis pepatah tradisional dan hukum adat yang digunakan sebagai alat untuk mengonstruksi kesadaran sosial. Permasalahan yang dibahas adalah pepatah tradisional dan hukum adat apa saja yang muncul dan bagaimana konteks kelahirannya, bagaimana konstruksi sosial yang berhubungan dengan ekologi bekerja melalui ungkapan tradisional dan hukum adat untuk membentuk kesadaran masyarakat Nusa Tenggara Barat, dan bagaimana praktek budaya, dalam diri individu dan masyarakat, seperti menjaga ekologi di Nusa Tenggara Barat, setelah nilai-nilai itu terinternalisasi. Hasil penelitian menunjukkan bahwa struktur sosial yang berubah di masyarakat sebagai akibat dari dinamika kekuasaan yang berubah telah berkontribusi terhadap pengetahuan dan membentuk kesadaran masyarakat terhadap lingkungan hidup. Bahasa merupakan representasi simbol legitimasi aturan masyarakat yang muncul dalam pepatah tradisional dan hukum adat. Pepatah tradisional dan hukum adat digunakan untuk mengonstruksi kesadaran masyarakat dari generasi ke generasi melalui proses internalisasi nilai.
\end{abstract}

Kata-Kata Kunci: Pepatah Tradisional dan Hukum Adat, Konstruksi Sosial, Ekologi

\section{PENDAHULUAN}

Bahasa sampai saat ini masih kuat sebagai representasi dari realitas yang paling dasar. Ketika sebagian masyarakat memiliki pengetahuan tertentu untuk mengatasi masalah-masalah ekologi, bahasa digunakan sebagai sarana legitimasi pengetahuan yang telah dilembagakan oleh masyarakat. Sementara, pengetahuan yang hadir dalam masyarakat berubah dari waktu ke waktu 
seiring dengan konteks kesejarahan masyarakat. Perjumpaan masyarakat dengan negara, agama, dan sistem ekonomi kapitalisme mengubah nalar masyarakat termasuk cara pandang masyarakat terhadap ekologi.

Isu bencana ekologi merupakan salah satu isu terhangat di dunia ketika masyarakat modern dengan pola pikir rasionalitas instrumental telah berjarak dengan alam, menganggap alam sebagai objek yang dapat dieksploitasi untuk keuntungan sebesar-besarnya manusia tanpa memikirkan keseimbangan. Bencana ekologi telah mematikan sendi-sendi kehidupan mendasar manusia dengan akibat kerugian. Di Lombok Barat, Nusa Tenggara Barat sebagai salah satu daerah pengamatan penelitian, kerusakan ekologi terjadi pada penyempitan lahan hutan mangrove. Wahyudewantoro (2018) mengatakan bahwa berkurangnya jumlah lahan mangrove disebabkan oleh meningkatnya pembangunan di daerah pantai, turisme, dan budidaya air laut. Laman Asia Ifad.org pada 12 Desember 2012 memberitakan pola penyusutan luasan ekosistem mangrove di Kabupaten Lombok Barat yang seharusnya memiliki potensi mangrove seluas 606,81 ha, berdasarkan hasil pendataan terlihat bahwa kategori kondisi mangrove rusak berat seluas 487,98 ha, dan rusak ringan 118,83 ha. Riggs, dkk. (2018) mengatakan sejak tahun 1990 hutan-hutan di Lombok telah beralih fungsi $28.6 \%$. Masyarakat bergantung pada hutan untuk keberlangsungan air, kayu bakar, kayu, dan produk hutan nonkayu. Layanan regulasi ekosistem di dalamnya termasuk pencegahan banjir, pengendalian erosi, dan penyerbukan tanaman inti. Masyarakat juga menetapkan nilai-nilai adat untuk tujuan seremoni di hutan dan juga mendapat pendapatan dari peariwisata atas keberadaan hutan tersebut.

Masalah ekologi bersumber dari pola pikir masyarakat yang menempati suatu wilayah atau bentang alam. Bentang alam yang telah rusak bisa ditelusuri dari bagaimana nalar masyarakat memandang lingkungannya dan termanifestasi dalam bahasa dan tindakan atau praktik budaya dalam hidup sehari-hari. Di beberapa daerah di Indonesia, pola pikir tentang keseimbangan ekologi muncul dalam narasinarasi seperti mitos, legenda, pepatah tradisional bahkan dalam bahasa yang denotatif seperti hukum adat yang semuanya merupakan bagian dari tradisi lisan.

Pepatah tradisional dan hukum adat yang menjadi subjek penelitian ini ranah bahasa dan sastra yang mengandung nilainilai kemanusiaan, sosial dan budaya juga terdapat pesan moral, anjuran serta harapan untuk menjaga kelestarian alam dan lingkungan, termasuk bencana ekologi yang disinggung pada pernyataan sebelumnya. Darman (2017:244) menyatakan sastra merupakan cabang ilmu yang sangat dekat dengan manusia sebagai subjek yang mengambil peran penting dalam hal penyelamatan lingkungan. Menurutnya, penyelamatan lingkungan bukan hanya masalah perlindungan lingkungan secara fisik tetapi juga berkaitan dengan etika hidup manusia.

Penelitian tentang pepatah tradisional dan hukum adat mendiskusikan empat hal yaitu ungkapan tradisional dan hukum adat apa sajakah yang digunakan sebagai alat legitimasi institusi, bagaimana konteks kemunculan pribahasa tradisional dan hukum adat yang berhubungan dengan perlindungan ekologi di daerah Nusa Tenggara Barat, bagaimana konstruksi sosial yang berhubungan dengan ekologi bekerja dalam membentuk kesadaran masyarakat di Nusa Tenggara Barat melalui ungkapan tradisional dan tata aturan adat, dan bagaimanakah praktik budaya dalam diri individu dan masyaraskat setelah proses internalisasi nilai-nilai menjaga ekologi di Nusa Tenggara Barat.

Penelitian kajian sastra lisan di beberapa daerah di Indonesia, khususnya di Nusa Tenggara memiliki tujuan untuk mendeskripsikan bahasa sebagai alat 
legitimasi institusi dalam ungkapan tradisional dan hukum adat dan menjelaskan konteks kemunculan ungkapan tradisional dan hukum adat yang berhubungan dengan perlindungan ekologi di daerah Nusa Tenggara Barat, menjelaskan proses konstruksi sosial yang berhubungan dengan ekologi bekerja dalam membentuk kesadaran masyarakat di Nusa Tenggara Barat melalui ungkapan tradisional dan hukum adat, serta mendeskripsikan praktik budaya dalam diri individu dan masyaraskat setelah proses internalisasi nilai-nilai menjaga ekologi di Nusa Tenggara Barat.

Penelitian-penelitian sebelumnya antara lain, Asrif La Madira (2015) tentang Wacana Mitos Imbu terhadap Pelindungan Alam laut Masyarakat Kepulauan Wakatobi. Andi Achdian (2015) Leuwung Hejo Masyarakat Ngejo (Hutan Hijau Masyarakat Sejahtera): Konstruksi Politik Hijau dan Siasat Politik Kontemporer dalam Tradisi Lisan Masyarakat Kasepuhan Kawasan Hutan Lindung Gunung Halimun, Kabupaten Lebak, Provinsi Banten. Hadirman (2015) dalam Mengkreasi Produk Kajian Ekolinguistik terhadap Tradisi Lisan Kabjanti di Muna: Menuju ke Arah Penguatan Kajian Eco-Oral Tradition dan Taena dkk (2016) tentang tradisi Falia yang dimiliki etnik Muna dalam menjaga hutan.

Asrif dalam tulisan tersebut mengangkat isu keefektifan mitos gurita raksasa berlengan sembilan yang mampu membunuh siapapun yang merusak lingkungan laut yang masih diyakini masyarakat hingga hari ini. Ingatan masyarakat pada mitos yang menjadi pengawas masyarakat kemudian menciptakan relasi keseimbangan yang positif antara manusia dan alam laut.

Andi Achdian mengungkap aspekaspek ritual, aturan lisan hingga klaim sejarah berabda-abad sebagai usaha melindungi diri ketika masyarakat kasepuhan di kawasan hutan lindung Gunung Halimun harus berhadapan dengan kekuatan negara dan pasar, sedangkan
Hardiman mengatakan bahwa perubahan bahasa dalam kabhanti menggambarkan perubahan ekologi baik alamiah maupun ekologi manusia dan budaya secara luas. Kabhanti sangat khas dengan penggunaan leksikon, frasa dan wacana yang mewadahi keberagaman hayati, flora dan fauna. Taena dkk. dalam pembahasan tradisi Falia pada suku Muna mengatakan bahwa tradisi falia mengontrol prilaku masyarakat Muna terhadap dalam memperlakukan hutan dengan keyakinan bahwa siapa pun yang merusak hutan akan mendapat hukuman secara supranatural salah satunya datangnya berbagai penyakit dan malapetaka lain.

Penelitian-penelitian di atas menunjukkan sumbangan tradisi lisan pada penjagaan lingkungan hidup. Akan tetapi keseluruhan penelitian tersebut belum membahas bagaimana proses penumbuhan kesadaran masyarakat melalui bahasa sebagai alat konstruksi sosial yang diwujudkan dalam pepatah tradisional dan hukum adat. Penelitian ungkapan bahasa termasuk di dalamnya tata aturan adat bagian dari tradisi lisan yang memiliki pesan verbal yang disampaikan dan dimaknai oleh anggota masyarakat. Dengan menggunakan kerangka teori konstruksi sosial, peneliti melihat bahwa pepatah tradisional, mitos dan larangan adat, termasuk hal-hal yang tabu merupakan pengetahuan yang hidup di tengah masyarakat. Proses pengetahuan yang berhubungan dengan penjagaan lingkungan hidup berada dalam masyarakat merupakan masalah yang didiskusikan dalam penelitian ini melalui bahasa sebagai alat pengonstruksi nalar masyarakat. Bahasa memberikan legitimasi langsung untuk mempertahankan institusi seperti lembaga adat yang membakukan aktivitas-aktivitas budaya masyarakat seperti ritual-ritual untuk menjaga lingkungan hidup.

Pesan-pesan yang dinarasikan menggunakan bahasa dalam bentuk pepatah, tabu, aturan adat diinternalisasikan ke dalam diri masyarakat, yang berujung pada usaha 
membentuk pola pikir, keyakinan dan menjaga prilaku masyarakat dan terus diwariskan. Aturan adat dan ungkapan bekerja sebagai pengawas dalam individu dan masyarakat. Satu sisi, pesan tersebut kemudian direspon oleh masyarakat setempat dalam bentuk praktik-praktik budaya seperti melakukan ritual untuk tetap seimbang dengan alam, mematuhi tabu-tabu dalam tindak tutur dan prilaku sehari-hari.

\section{LANDASAN TEORI}

Kontruksi sosial, sebuah konsep yang dipinjam dari ilmu sosial yang dikembangkan oleh Berger dan Luckmann (1967) menyatakan bahwa realitas adalah konstruksi sosial. Realitas dalam pandangan Berger dibagi dalam realitas yang objektif dan subjektif. Pertama, realitas yang objektif di dalamnya terdapat struktur sosial yang merupakan ranah yang membuat kehidupan manusia teratur dan tentram, diantaranya terdapat institusi dan tindakan sosial. Struktur sosial menjadi patokan manusia dalam berpikir dan bertindak meskipun tidak membatasi tindakan manusia yang subjektif. Kemudian kedua, realitas subjektif, yaitu isi atau makna struktur sosial yang dapat dipahami dari sudut pandang anggota masyarakat yang berada di bawah naungannya.

Proses konstruksi sosial berlangsung dalam cara bagaimana suatu pengetahuan bisa berada di tengah masyarakat. Berger menjelaskan proses pembentukan realitas sosial berada di dalam kesadaran manusia. Realitas dibentuk oleh kesadaran manusia dengan merujuk pada relasi logis fakta-fakta yang dialaminya. Salah satu fakta yang dialami manusia adalah kebutuhan hidup. Kebutuhan tersebut repetitif hingga terbentuknya kaidah atau institusi untuk mengorganisasi pemerolehan kebutuhan tersebut sehingga tercipta rasa aman. Berger dalam Riyanto (2009) mengatakan dalam pemenuhan kebutuhan terjadi interaksi individu dengan masyarakat yang prosesnya melalui ekternalisasi (objektivikasi) dan internalisasi. Pembentukan institusi ini disebut ekternalisasi, sedangkan internalisasi adalah proses ketika manusia dibentuk atau produk dari masyarakat. Internalisasi ini memiliki fungsi mentransmisikan intitusi kepada anggota masyarakat agar institusi tersebut (dan perangkat aturannya) tetap bertahan dari waktu ke waktu. Manusia yang mengonsepsikan institusi tersebut juga terus mengalami internalisasi agar status objektivitas institusi yang dikonsepkan dalam kesadaran tetap kukuh. Dengan demikian hubungan dialog manusia dan masyarakat adalah manusia membentuk masyarakat dan manusia dibentuk oleh masyarakat.

Institusi yang hadir membutuhkan legitimasi atau pengesahan untuk menjelaskan secara kognitif alasan adanya institusi itu. Legitimasi memiliki empat tingkatan yang semakin tinggi tingkatannya menunjukkan legitimasi tersebut bersifat koheren dan teoritis. Tingkatan pertama legitimasi adalah bahasa. Bahasa merupakan representasi dari realitas yang paling dasar. Bahasa memberikan legitimasi langsung untuk mempertahankan institusi. Tingkatan kedua, bahasa yang diwujudkan dalam pepatah atau ungkapan yang konotatif. Tingkatan legitimasi ketiga adalah teori yang dirumuskan masyarakat yang sudah sangat memahami masalah-masalah terkait, misalnya pemimpin spiritual yang memahami diadakannya ritual. Legitimasi teoritis ini disebut tatanan simbolik atau symbolic order yang dicontohkan dengan agama (keyakinan) atau melalui paradigma ilmu pengetahuan. (Berger dalam Riyanto, 2009)

Selain Berger dan Luckmann, pada tahun 1991 Bruner megemukakan konsep konstruksi narasi. Antara konstruksi narasi dan konstruksi sosial mempunyai titik temu pada hubungan antara konstruksi sosial terhadap realitas dan interaksi manusia sebagai subjek yang melakukan konstruksi terhadap realitas. Menurut Bruner konstruksi realitas disokong oleh prinsip-prisip dan 
prosedur yang berupa perlatan tradisi yang dimodelkan dan disebarluaskan. Pengalaman manusia disusun dalam narasi-narasi yang berbentuk cerita rakyat, mitos, alasan untuk melakukan sesuatu atau tidak, dan sebagainya.

$\begin{array}{rrr}\text { Mengkonstruksi } & \text { realitas } & \text { dengan } \\ \text { narasi membutuhkan } & \text { bahasa. } & \text { Bruner }\end{array}$ menekankan bahwa manusia membangun ide-ide satu sama lain, mengalami peristiwa bersama, dan memiliki memori dalam kehidupan sehari-hari dalam bentuk narasi. Narasi merupakan versi dari realitas dan instrumen pikiran yang digunakan sebagai alat pengkonstruksian. Konstruksi sosial dan konstruksi narasi menghubungkan tradisi lisan dengan realitas dalam kehidupan sehari-hari.

\section{METODE}

Penelitian ini di wilayah field research (riset lapangan) pada tanggal 6-10 Oktober 2015 di Lombok dengan pendekatan kualitatif yang dilakukan dengan cara melakukan wawancara kepada beberapa jenis informan. Hasil-hasil data pengumpulan ungkapan tradisional dan aturan adat kemudian ditranskripsi dan dianalisis dengan kerangka konstruksi sosial. Data-data yang didapatkan dari riset lapangan menjadi data primer, sedangkan sumber data sekunder sebagai sumber data penunjang dalam penelitian ini adalah datadata yang diperoleh dari studi kepustakaan baik dari buku-buku maupun sumber lain.

\section{PEMBAHASAN}

\section{Struktur sosial budaya Komunitas}

Struktur sosial budaya komunitas mencakup pelembagaan kebiasaan atau habituasi. Pelembagaan bagian dari upaya mempertahankan pola-pola yang dianggap akan memberi keteraturan, dan ketenangan. Pembiasaan merupakan proses yang terusmenerus dijalani, kemudian dibuat aturan dan kontrol terhadap aturan tersebut. Ritual merupakan pola yang diulang-ulang oleh masyarakat yang kemudian dibuat sistematikanya oleh pelaku-pelaku yang berkepentingan terhadap ritual tersebut untuk terus diajarkan dan diingat oleh masyarakat. Sedangkan aturan adat bagian dari mekanisme pengontrolan sesuatu yang dilakukan sebagaimana biasa untuk tujuan tertentu. Dengan demikian dalam pelembagaan terdapat dua sisi yaitu tindakan yang dibiasakan dan pelaku yang mempraktikkan termasuk yang memimpin atau mengontrol.

Bentang geografis laut, gunung di tempat hidup masyarakat Sasak di Lombok menimbulkan kelahiran lembaga adat untuk mengatur, dan menyelesaikan persoalan yang berhubungan dengan bentang alam tersebut. Misalnya, dalam masyarakat Lombok pelembagaan terhadap kebiasaan mensucikan air laut timbul upacara bau nyale. Pengaturan ritual itu sendiri supaya terus menerus bisa dilaksanakan yang kemudian menimbulkan kebutuhan akan lembaga yang mengurus tata upacara keagamaan. Lembaga adat masyarakat Sasak yang setelah kedatangan Islam mensikretikkan ajaran-ajaran atau aturan yang dikosepsikan dalam pikiran masyarakat Sasak terdiri dari pemuka adat. Pemuka adat bertugas mengatur aspek Watu Telu, suatu kepercayaan sinkretik antara Islam, Hindu dan agama pagan masyarakat. Pemuka adat disebut pemangku. Meskipun pemangku dalam hirarki masyarakat Sasak bukan dari golongan bangsawan, tetapi pemangku adalah petugas adat yang penting dalam komunitas yang bertugas dalam setiap upacara.

Pada komunitas Sasak terdapat kelompok-kelompok pemangku di antaranya pemangku gubug yang mengurusi perumahan komunitas ketika memperantarai hubungan komunitas dengan dunia spritual. Pemangku aiq mengurusi pertanian Subak yaitu proses pengairan dari mata air yang membutuhkan tata cara spiritual dalam pelaksanaan pengairan dari mata air. Kelompok pemangku ini menjaga tata cara yang diajarkan dari sistem kepercayaan yang 
juga sudah dilembagakan, yaitu Watu Telu. Pemangku merupakan struktur yang berada di bawah para bangsawan.

Bangsawan dalam lembaga adat Sasak menempati posisi tertinggi dalam keyakinan masyarakat. Masyarakat yang mempercayai kekuatan supranatural melanggengkan pelembagaan sistem sosial bertingkat berdasarkan referensi kosmologi sinkretis Watu Telu. Struktur ini juga menentukan kepemilikan tanah. Bangsawan berhak mengusai tanah-tanah atas nama adat. Strata ini dilembagakan sebagai suatu cara menjaga kemurnian bangsawan sehingga tetap berada dalam posisi tertiggi di atas masyarakat biasa. Perkawinan endogami atau perkawinan sesama kelompok yang setara merupakan usaha mempertahankan posisi tertinggi tersebut. Jika terdapat bangsawan yang melakukan perkawinan eksogami dianggap telah mengkhianati leluhur yang akibatnya bangsawan tersebut kehilangan kekuatan supranatural. Dalam struktur komunitas tersebut posisi perempuan bangsawan menjadi sangat penting dalam menjaga kelestarian perkawinan endogami. Akan tetapi posisi kebangsawan pada masyarakat Lombok sekarang sudah mengalami transformasi sosial seiring dengan masuknya ajaran Islam yang tidak mempercayai sistem kekastaan.

Struktur sosial budaya komunitas sasak yang menganut Islam awal di Lombok terdiri dari Tuan Guru yang menjadi panutan bagi masyarakat. Tuan Guru adalah orang yang mempunyai keilmuan di bidang agama Islam. Tidak hanya panutan dalam bidang ilmu agama, Suprapto (2015) mengatakan, Tuan Guru juga memegang peran penting dalam integrasi masyarakat Sasak dan menyelesaikan konflik apabila terjadi konflik etnik dan agama di P. Lombok. Di masa awal, Tuan Guru berasal dari kalangan pedagang yang menyebarkan Islam melalui perdagangan di wilayah pesisir yang kebanyakan berasal dari kesultanan Makasar. Di masa berikutnya ketika banyak bangsawan Sasak dari kedatuan Selaprang belajar ilmu Islam hingga ke negeri Arab di Mekah mereka juga menjadi tokoh-tokoh perubahan sosial masyarakat Sasak. Tidak hanya bidang transformasi sosial, peran Tuan Guru juga pemimpin peperangan melawan kerajaan Bali yang berkuasa di wilayah Barat, juga pemimpin perjuangan melawan penjajahan Belanda.

Salah satu Tuan Guru yang sangat berpengaruh dalam masyarakat Sasak adalah TGKH Syaikh Muhammad Zainuddin Abdul Madjid, pendiri Nahdlatul Wathan, organisasi massa Islam yang terbesar di provinsi Nusa Tenggara Barat / NTB. Adawiyah (2009) mencatatkan biografi Tuan Guru Zainuddin dalam tesis berjudul Pendidikan Pesantren Menurut Pemikiran Tuan Guru Kyai Haji Muhammad Zainuddin Abdul Madjid. Adawiyah mengatakan bahwa setelah belajar di Mekah selama 6 tahun di Madrasah Ash Shaulatiyah yang dipimpin oleh Syaikh Salim Rahmatullah, Tuan Guru Zainuddin kembali ke Lombok dan mendirikan Madrasah Al Mujahidin (1934 M. Madrasah ini kemudian menjadi pokok berdirinya organisasai agama terbesar di NTB yaitu Pondok Pesantren Nahdlatul Wathan (NW), yang menjadi perintis dan penggerak sosial keagamaan di Lombok dan Sumbawa. Pondok pesantren NW kemudian melahirkan banyak kalangan yang terdisik di Lombok dan Sumbawa yang menjadi agen perubahan sosial pada masyarakat Lombok saat ini.

Di samping Tuan Guru atau disebut Lokaq atau Kyai yang danggap pemegang kosmos, struktur sosial masyarakat Sasak masa Islam awal dibantu oleh pemegang pemegang hukum yaitu Penghulu, pemegang wilayah yaitu Pembekel, dan Pemegang Keahlian Balian. Di masa sekarang ketika dalam masa administratif pemerintahan RI, pemerintahan administratif seperti kepala desa berperan dalam memegang pimpinan pemerintahan di tingkat desa. Akan tetapi kehidupan sosial masyarakat di masa administrasi modern 
juga banyak dipengaruhi oleh kehidupan organisasi politik yang wilayah kerjanya sampai ke desa-desa terutama saat akan diadakannya pemilihan umum. Struktur pemerintahan nasional dalam era media massa dan elektronik menjadi pelaku-pelaku transformasi sosial di masa kini. Tuan Guru masih memiliki wibawa yang sangat besar sebagai pelaku perubahan, bahkan partaipartai politik berlomba melakukan pendekatan terhadap Tuan-Tuan Guru dalam rangka mendapat dukungan dengan demikian tujuan praktis memenangkan pemilihan umum.

Ajaran-ajaran yang disampaikan Tuan Guru telah mengubah pola pikir masyarakat di Lombok termasuk pola pikir terhadap lingkungan hidup. Watu Telu yang singkretik dengan budaya masyarakt lokal memulaikan alam karena sistem kepercayaan bahwa alam mengandung kekuatan yang harus ditakuti. Pada masa islam berikutnya yang diajarkan Tuan Guru pada masa awal masih bercorak esoteris, yakni islam dengan pendekatan sufisme yang membuka keyakinan pada hubungan kedekatan dengan alam. Tetapi masa Tuan Guru akhir pada abad pertengahan 20, Islam dengan pendekatan eksoteris atau hukum syariah menjadi lebih dominan dan menghapus kepercayaan-keperayaan yang menurut islam ini bid'ah. Islam eksoteris membuka pola pikir baru tentang ekologi yang bersifat penguasaan, karena kekuatannya menundukkan alam dan segala praktik budaya yang tunduk pada alam.

\section{Bahasa dalam Ungkapan Tradisional sebagai Representasi Simbolik Legitimasi Aturan}

Bentang alam baik laut, dataran pegunungan maupun dataran rendah di Pulau Lombok diatur dalam ungkapan atau tata aturan adat yang merupakan derivasi dari konsep kosmologi masyarakat Sasak. Gumi Paer yang merupakan lokus geografis bagi masyarakat Sasak yang tinggal di atasnya melahirkan pranata-pranata sosial yang dilembagakan disahkan atau dilegitimasi melalui bahasa.

Ungkapan atau Tata Aturan Adat merupakan ekspresi peligitimasian pranatapranata sebagai konsekwensi komitmen hidup bersama. Komitmen yang muncul dari institusionalisasi kebiasaan hidup sehari-hari dibakukan oleh masyarakat dalam bentuk tata aturan adat dan ungkapan berbahasa. Dalam bidang ekologi di Lombok terdapat ungkapan atau tata aturan adat yang mengatur hubungan antara manusia dan alam. Tata aturan adat ini menghasilkan istilah mali atau tabu untuk dilanggar.

\section{Pelindungan Laut}

Dalam masyarakat Sasak dikenal dengan ungkapan seda' karangseda` diri. Ungkapan ini berarti merusak batu karang itu sama dengan merusak diri sendiri. Selain ungkapan itu terdapat juga Dendek pade sedak karang-karang lek segare yang berarti dilarang merusak terumbu karang di laut dan ungkapan endak lepas jaring elek sedi laun ede karang dekne arak taok mpak bebale yang berarti jangan tebar jala di pinggir laut nanti tidak ada tempat ikan bersarang.

Terumbu karang bagian dari habitat mahluk laut. Terumbu karang merupakan suatu ekosistem yang menunjang kehidupan berbagai jenis makhluk hidup yang ada di sekitar terumbu karang. Dengan adanya terumbu karang maka tumbuhan dan hewan laut lainnya dapat tinggal, mencari makan dan berkembang biak di terumbu karang. Menurut penjelasan yayasan di bidang penyelamatan terumbu karang yang dipublikasikan dalam laman http://www.terangi.or.id, terumbu karang memiliki biodiversitas tertinggi dalam tingkatan filum. Terumbu karang juga merupakan ekosistem dengan biodiversitas tertinggi dibandingkan ekosistem pesisir dan laut lainnya, dalam unit skala tertentu. Artinya dalam luas $1 \mathrm{~km}^{2}$ di wilayah terumbu karang mengandung lebih banyak spesies dibandingkan dengan $1 \mathrm{~km}^{2}$ di 
wilayah laut dalam. Tingkat biodiveristas terumbu karang yang tinggi akan menjadi sumber keanekaragaman genetik dan spesies. Keanekaragaman genetik yang dimaksud di sini banyaknya variasi dalam makhluk hidup sehingga tingkat ketahanan terhadap penyakit dan kemampuan bertahan hidup suatu makhluk hidup dapat menjadi lebih tinggi. Selain itu dengan begitu banyaknya spesies maka akan dapat dimanfaatkan untuk sebagai sumber pangan dan obat-obatan.

Terumbu karang juga benteng pertama yang melindungi pantai. Terumbu karang, padang lamun dan hutan bakau merupakan ekosistem yang saling berhubungan. Terumbu karang merupakan tumbuhan yang pertama kali menghalau ombak besar dari laut, agar tidak merusak daratan. Kemudian ombak tiba di padang lamun maka energinya akan diperkecil lagi oleh daun-daun tumbuhan lamun. Ketika ombak tiba di dekat pantai, maka akar dan batang pohon-pohon mangrove akan memperkecil lagi energi ombak, sehingga ombak tidak merusak pantai. Terumbu karang bermanfaat dalam menghalangi pengikisan akibat energi ombak dan arus, sehingga masalah abrasi pantai yang mengikis daratan pulau-pulau akan lebih mudah diatasi. Bahkan artikel tersebut juga menjelaskan bahwa terumbu karang juga berfungsi mengurangi pemanasan global seperti hutan hujan tropis, terumbu karang menyerap gas $\mathrm{CO}_{2}$ hasil pembakaran sehingga mengurangi pemanasan pada bumi, mencegah perubahan iklim.

Bagi masyarakat Sasak kosmologi laut yang dianggap suci dibahasakan dengan ungkapan-ungkapan dan larangan antara lain dilarang membuang kotoran manusia di laut, nanti tidak akan melihat kotoranmu lagi. Disucikannya laut bagi orang Sasak juga menimbulkan ungkapan-ungkapan atau aturan adat yang dilarang berzina di laut, dan dilaranag membawa perempuan ke laut ketika menstrusasi.
Larangan pergi ke laut di hari Jumat supaya laki-laki menjalankan peribadatan salat Jumat. Larangan tersebut mempunyai pendasaran keseimbangan bagi manusia antara mencari nafkah dan peribadatan. Larangan bertengkar di laut, dan larangan menyebut gurita ketika berada di laut. Gurita adalah binatang yang menakutkan bagi nelayan Sasak yang dapat membunuh manusia. Gurita yang dimaksud adalah bagian dari epen laut atau mahluk halus dalam laut yang dipercayai sebagai sesuatu yang menakutkan. Oleh karena itu dianggap tabu menyebut gurita secara verbal sebagai nama panggilannya ketika sedang berada di laut. Sedangkan bertengkar di laut menandakan hawa nafsu yang tidak boleh diperturutkan ketika di laut karena akan berakibat tidak saja ikan yang sedang dicari akan hilang atau tidak jadi menjadi rezeki tetapi berakibat merusak hubungan sesama manusia atau nelayan yang sedang bersamasama berangkat mencari ikan di laut.

\section{Pelindungan Hutan dan alam lingkungan sekitar}

Hutan di sekitar kawasan Gunung Rinjani di Sembalun, Lombok Timur memiliki tata hukum adat salah satunya larangan tidak boleh membawa makananmakanan yang berbumbu. Makanan berbumbu mengandung hawa panas yang dan merusak rumput-rumut di bawah pohon. Rumput-rumputan adalah tanaman penutup permukaan tanah untuk melindungi tanah dari ancaman kerusakan oleh erosi dan / atau untuk memperbaiki sifat kimia dan sifat fisik tanah. Tanaman penutup tanah berperan: (1) menahan atau mengurangi daya perusak butir-butir hujan yang jatuh dan aliran air di atas permukaan tanah, (2) menambah bahan organik tanah melalui batang, ranting dan daun mati yang jatuh, dan (3) melakukan transpirasi, yang mengurangi kandungan air tanah. Peranan tanaman penutup tanah tersebut menyebabkan berkurangnya kekuatan dispersi air hujan, mengurangi jumlah serta 
kecepatan aliran. Ketika daerah sekitar kawasan hutan Rijani menjadi area wisata, pemerintah membantu penjagaan ekologi sekitar hutan lindung Rinjani dengan menerapkan ekowisata. Bonita dalam Sadikin dkk. (2017) mengatakan bahwa aktivitas ekowisata berupa lintasan trekking menuju puncak Gunung Rinjani dan danau Segara Anak yang melewati zona larangan karena dapat menggagu flora dan fauna. Dengan demikian beberapa hal sangat perlu diperhatikan bagi para wisatawan antara lain dilarang memasak, membunyikan suara-suara dan membuat bebauan.

\section{Internalisasi Ungkapan/Tata Aturan Adat Pada Masyarakat}

Bagian ini membahas pelembagaan nilai-nilai ekologi dilakukan melalui proses internalisasi dalam pola pikir masyarakat. Internalisasi ungkapan/tata aturan adat berfungsi mentransmisikan institusi atau kebiasaan yang dilembagakan kepada anggota masyarakat agar institusi tersebut tetap bertahan.Internalisasi dilakukan dengan cara sosialisasi suatu kebiasaan. Paparan di bawah ini akan membahas mekanisme sosialisasi nilai-nilai penjagaan ekologi di Lombok dalam bentuk ritual.

Ritual adalah salah satu cara internalisasi ungkapan tradisional. Ritual atau upacara adat bagian dari sosialisasi nilai-nilai dalam hal ini yang berhubungan dengan penjagaan ekologi. Pada masyarakat Lombok dikenal upacara Metulak atau upacara menolak bala. Tulak artinya kembali. Metulak berarti mengembalikan. Upacara ini dikerjakan oleh masyarakat yang seketurunan berasal dari desa induk yang sama. Pada kesempatan ini upacara dilaksanakan di desa Pujut.

Upacara Metulak diadakan setiap empat tahun sekali. Jenis bala atau wabah yang ditolak adalah yang menyerang padi, ternak, juga wabah yag menimpa manusia. Tujuan upacara ini keselamatan seluruh manusia maka yang harus dilakukan adalah memelihara lingkungan tempat manusia hidup. Sebelum pelaksanaan upacara masyarakat bekerja bakti membersihkan lingkungan sekitar. Kerja bakti yang dilakukan rutin ini dan turun temurun ini memasukkan suatu kebiasaan pad masyarakat yang membentuk pola pikir tentang menjaga lingkungan untuk menolak bala.

Selain upacara Metula juga terdapat upacara bau nyale. Kata Nyale berasal dari nama sejenis cacing laut yang biasa hidup di dasar laut atau lubang-lubang batu karang. Masyarakat meyakini Nyale adalah jelmaan dari rambut Putri Mandalika, seorang putri raja di Pulau Lombok. Kecantikannya ternyata memukau banyak pangeran di Pulau Lombok sehingga banyak pinangan yang menghampiri dirinya. Karena bingung, Sang Putri memutuskan untuk menceburkan diri ke Pantai Selatan. Setelah kejadian tersebut, setiap tahun munculah Nyale yang dipercaya sebagai jelmaan dari rambut Putri Mandalika.

Bau Nyale merupakan ritual menangkap cacing laut yang biasanya keluar di daerah pantai Kuta pada bulan-bulan tertentu. Cacing-cacing yang berwarna hijau, coklat, oranye hingga merah ini akan keluar pada tengah malam hingga pagi hari ketika pesisir laut mulai surut. Ada 16 titik pantai di Selatan Lombok Tengah yang memanjang sejauh puluhan kilometer dari arah Timur hingga barat seperti di Pantai Kaliantan, Pantai Kuta atau Pantai Selong Belanak. Cacing yang ditangkap pada ritual ini nantinya akan dikonsumsi warga dengan dimasak dan dimakan bersama-sama.

Ritual bau nyale mensosialisasikan nilai menjaga lingkungan laut dengan demikian tidak hanya cacing-cacing yang tiap tahun dapat ditangkap dan dikonsumsi tetapi juga terjagaya terumbu karang dan ikan-ikan dan seluruh habitat pada ekosistem laut.

Sosialisasi penjagaan lingkungan hidup juga dilakukan oleh pemerintah dengan aturan Sassi. Aturan yang berbentuk perda tersebut bagian dari internalisasi 
menjaga laingkungan laut. Sassi merupakan aturan libur menangkap ikan selama beberapa hari yang berguna untuk memberi waktu pada ikan berkembang biak.

\section{Implikasi Ungkapan/Tata Aturan Adat Pada Masyarakat.}

Bagian ini akan menjelaskan sikap masyarakat terhadap ungkapan/tata aturan adat yang ditanamkan oleh institusi. Masyarakat baik di Bali dan Lombok saat ini sebagian besar masih meyakini pentingnya keseimbangan alam terutama pada masyarakat yang tinggal di wilayah lingkungan geografis pesisir pantai dan pegunungam, dan masih mengenal tata aturan adat dalam bentuk tabu. Bagian ini juga membahas pihak-pihak yang tidak menganggap bahwa keseimbangan ekologi itu penting.

Di Lombok masyarakat juga masih sangat takut melanggar pantangan-pantangan yang ditetapkan juga takut tidak menyelenggarakan ritual-ritual tertentu. Meskipun ajaran islam eksoteris yang menekankan syariah menyebar pada masyarakat Lombok, tetapi ajaran tersebut tidak mengurangi kepercayaan mereka pada tabu-tabu tertentu seperti tidak melaut di hari Jumat. Seorang nelayan yang tinggal di Lombok Timur mengatakan bahwa tiap hari Jumat ia tidak pergi melaut, juga pada saat ditetapkannya sassi. Akan tetapi tidak semua masyaakat di Lombok masih mempercayai dan mematuhi tabu-tabu tersebut. Agama Islam berperan penting dalam menggeser keyakinan masyarakat pada tabu sehingga ungkapan tradisional tidak memiliki makna lagi. Dinamika sosial kemunculan penguasapenguasa di Lombok yang berpengaruh terhadap masyarakat Lombok.

\section{PENUTUP}

Penelitian tentang ungkapan/tata aturan adat sebagai konstruksi sosial berbasis lingkungan hidup mempermasalahkan bahasa yang digunakan sebagai sarana pelegitimasian pengetahuan tentang ekologi yang telah dilembagakan oleh masyarakat. Pengetahuan membentuk pola pikir, sedangkan pengetahuan terus berubah seiring dengan perubahan kekuasaan atau struktur masyarakat yang menanamkan pengetahuan. Pola pikir masyarakat termanifestasi dalam bahasa dan tindakan atau praktik budaya dalam hidup sehari-hari.

Pengetahuan masyarakat tentang lingkungan hidup juga mengalami perubahan. Pandangan masyarakat tentang alam yang semula tunduk terhadap alam sebagian telah berubah pada penaklukan terhadap alam. Pandangan alam sebagai objek yang ditaklukkan mengakibatkan praktik hidup yangsemena-mena terhadap lingkunga hidup dan terjadi yang disebut dengan bencana ekologi. Isu bencana ekologi kini menjadi isu global yang membahayakan kesejahteraan umat manusia.

Berdasarkan latar belakang masalah tersebut terdapat tiga masalah yang didiskusikan antara lain pertama, sebagai alat legitimasi institusi, ungkapan tradisional/tata aturan adat apa saja dan bagaimana konteks kemunculan ungkapan tradisional/tata aturan adat yang berhubungan dengan perlindungan ekologi di Nusa Tenggara Barat. Kedua bagaimana konstruksi sosial yang berhubungan dengan ekologi bekerja dalam membentuk pola pikir masyarakat di Nusa Tenggara Barat dan Bali melalui ungkapan tradisional dan tata aturan adat. Ketiga, bagaimanakah praktik budaya dalam diri individu dan masyarakat setelah proses internalisasi nilai-nilai menjaga ekologi di Sumatera Barat, Nusa Tenggara Barat, dan Bali.

Hasil pembahasan masalah-masalah yang dirumuskan di atas antara lain bahwa struktur sosial yang berubah di masyarakat sebagai akibat dari dinamika kekuasaan yang berubah telah memberikan jejak pengetahuan dan membentuk pola pikir masyarakat terhadap lingkungan hidup. Pengetahuan tersebut diamati dari praktik 
budaya atau pembiasaan prilaku terhadap lingkungan hidup yang kemudian dilembagakan atau diinstitusikan. Pembiasaan tersebut dilegitimasi melalui bahasa yang muncul pada bentuk konotatif yaitu ungkapan dan denotatif yaitu tata aturan adat.

Bahasa merupakan representasi Simbolik Legitimasi Aturan Masyarakat yang muncul dalam nasehat yaitu ungkapan juga tabu dan tata aturan adat. Di Lombok aturan adat lebih dipraktikkan dalam kehidupan sehari-hari masyarakat, meskipun terdapat juga bahasa konotatif yaitu ungkapan. Ungkapan/tata aturan adat tersebut muncul dengan memiliki konteks kesejarahan masyarakat, dan sosial budaya.

Ungkapan/tata aturan adat sebagai alat pengkonstruksi sosial di dalam pola pikir masyarakat dilakukan melalui proses internalisasi. Bahasa berbentuk ungkapan/tata aturan adat yang meligitimasi suatu lembaga atau intitusi terus menerus ditransmisikan atau disosialisasikan pada masyarakat dengan cara penanaman kesadaran. Ritual-ritual merupakan cara yang rutin yang berfungsi mensosialisasikan tata aturan adat/ungkapan sehingga masyarakat selalu mengingat dan mempraktikkan aturan menjaga lingkungan hidup.

Kerusakan lingkungan hidup tetap terjadi daerah penelitian tersebut. Ini menunjukkan bahwa di tingkat praktik ada yang tidak sesuai antara ungkapan/tata aturan adat yang ditanamkan oleh struktur sosial kepada masyarakat dengan praktik budaya atau pola pikir yang ada di dalam masyarakat. Akan tetapi di tingkat masyarakat Lombok masih banyak masyarakat yang mempercayai dan mentaati aturan dan sadar pada keseimbangan alam. Pertanyaan yang muncul kembali setelah penelitian ini adalah masyarakat yang mana yang tidak mentaati dan struktur sosial yang mana yang tidak memperdulikan lagi ekologi. Persoalan struktur pemerintahan nasional dalam negara dan hubungan negara dengan korporasi-korporasi swasta belum dibahas dalam penelitian ini yang mungkin menjadi sebab kerusakan lingkungan. Korporasi yang dikembangkan berdasarkan bisnis yang meraih keuntungan sebanyakbanyaknya memiliki pola pikir yang berbeda terhadap alam dan memiliki legitimasi dalam bahasa yang berbeda.

\section{DAFTAR PUSTAKA}

Achdian, Andi. 2015. "Leuwung Hejo Masyarakat Ngejo (Hutan Hijau Masyarakat Sejahtera):Konstruksi Politik Hijau dan Siasat Politik Kontemporer dalam Tradisi Lisan Masyarakat Kasepuhan Kawasan Hutan Lindung Gunung Halimun, Kabupaten Lebak, Provinsi Banten", dalam Merayakan Keberagaman Tradisi Sebagai Warisan Budaya prosiding Seminar Internasional dan Festival Tradisi Lisan IX Wakatobi, 12-15 Juni 2015.

Adawiyah, Muazzatun. 2009. Pendidikan Pesantren Menurut Pemikiran Tuan Guru Kyai Haji Muhammad Zainuddin Abdul Madjid. Tesis Pasca Sarjana UIN Sunan Kalijaga, Yogyakarta. (http://digilib.uinsuka.ac.id/6932/1 /BAB\%20I\%2C\%20V\%2C\%20D AFTAR\%20PUSTAKA.pdf) diakses tanggal 17 Mei 2018.

Berger, Peter L and Luckmann, Thomas. 1967. The Social Construction of Reality A Treatise In The Sociology of Knpowledge. New York: Penguin Press

Bonita MK dalam Sadikin, Pipin Noviati., Arifin, Hadi Susilo., Pramudya, Bambang., Mulatsih, Sri. 2017. "Carrying Capacity to Preserve Biodiversity on Ecotourism in Mount Rinjani National Park, Indonesia". Biodiversitas. Vol.18, No. 3. hlm. 978-989. 
Cederroth, Sven. 1981. The Spell of The Ancestors And The Power of Mekkah A Sasak Community on Lombok. Sweden: Vasastadens Bokbinderi.

Darman, Faradika. 2017. "Representasi Manusia dan Alam dalam Puisi $\mathrm{Aku}$, Hutan Jati dan Indonesia Karya Yacinta Kurniasih". Totobuang, Vol.5, No. 2. hlm. $243-254$.

Hardiman. 2015. "Mengkreasi Produk Kajian Ekolinguistik terhadap Tradisi Lisan Kabjanti di Muna: Menuju ke Arah Penguatan Kajian Eco-Oral Tradition dalam Merayakan Keberagaman Tradisi Sebagai Warisan Budaya prosiding Seminar Internasional dan Festival Tradisi Lisan IX Wakatobi, 12--15 Juni 2015.

Jerome, Brunner. 1991. The Narrative Construction of Reality. In the Critical Inquiry 18. (Autumn 1991), The University of Chicago.

Lamadira, Asrif. 2015. "Mitos Imbu Pada Masyarakat Wakatobi". Tradition dalam Merayakan Keberagaman Tradisi Sebagai Warisan Budaya prosiding Seminar Internasional dan Festival Tradisi Lisan IX Wakatobi, 12--15 Juni 2015.

Riggs, Rebecca A., Langston, James D., Margules, Chris., Boedhihartono, Agni Klintuni ., She Lim, Han., Sari, Dwi Amalia., Sururi, Yazid., Sayer, Jeffrey. 2018. "Governance Challenges in an Eastern Indonesian Forest Lanscape". Sustainability, Vol. 10, No. 169

(www.mdpi.com/journal/sustainab ility), diakses tanggal 17 Mei 2018.
Riyanto, Geger. 2009. Peter L Berger Perspektif Metatoeri Pemikiran. Jakarta: LP3S

Suprapto. 2015. "Religious Leaders and Peace Building The Roles of Tuan Guru and Pedanda in Conflict Resolution in Lombok Indonesia". Al-Jāmi'ah: Journal of Islamic Studies. Vol. 53, no.1. hlm. 225250. DOI. 10.14421.

Taena1, La., Sailan, Zalili., Nalefo, La., Basri, Ali., Laepe, Ader., Samsul., Helmina, Siti., Miliha, La., Kuasa, Wa. 2016. "The Cultural Tradition of Falia in Preserving Forest by Munanese Ethnic". Journal of Sustainable Development. Vol. 9, No. 5. hlm. 200-206.

Wahyudewantoro, Gema. 2018. "The Fish Diversity of Mangorove Waters in Lombok Island, West Nusa Tenggara, Indonesia". Biodiversitas. Vol. 19, no.1. hlm. 71-76.

Zaelani, Kamaluddin. 2007. Satu Agama Banyak Tuhan. Mataram: Pantheon Media Pressindo.

Sumber Internet

Asia Ifada Org. 2012. Kerusakan Ekosistem Mangrove dan Upaya Pelestariannya di kabupaten Lombok Barat. https://asia.ifad.org/web/indonesia /home/-/news/6160/newsletter. Diakses 12 Desember 2015.

Yayasan Terumbu Karang Indonesia. Terumbu Karang: Manfaat Ekologi dan Ekonomi, Beserta Faktor Pengancamnya. https://www.slideshare.net/terangi 2011/terumbu-karang-manfaatekologi-dan-ekonomi-besertafaktor-pengancamnya. diakses 7 November

2015 


\begin{tabular}{|lcl|}
\hline \multicolumn{3}{|c|}{ TOTOBUANG } \\
\hline Volume 6 & Nomor 1, Juni 2018 & Halaman 59-68 \\
\hline
\end{tabular}

\title{
APLIKASI MAKNA MITOS BANYU DALAM BAHASA BANJAR (The Application of Mythical Meaning of "Banyu" in Banjar Language)
}

\author{
Rissari Yayuk \\ Balai Bahasa Provinsi Kalimantan Selatan \\ Jln. A. Yani, Lok Tabat, Banjarbaru, Kalimantan Selatan \\ Pos-el: yrissariyayuk@yahoo.co.id
}

(Diterima: 7 Maret 2018; Direvisi 25 Mei 2018; Disetujui: 3 Juni 2018)

\begin{abstract}
This research studied about how the mythical meaning of Banyu (water) applyed in Banjar language based on the lexicon and contextual source. The purpose of this research was describing the myth meaning of Banyu in Banjar language based on its lexicon source and the function based on its contextl. The research method was qualitative descriptive.The data collection techniques had used observing-conversation technique. The frame of work was data collection, data processing, and results of data analysis. The sampling technique that used in this paper was the purposive sampling, the sampling technique of data source collection with considering. The data collection that had been takenfrom January to December 2017. The place where data were collectedwas at Padang Village, Banjar Regency. The data presentation was using ordinary words. The result showed thath myth meaning of Banyu that applyed in Banjar language based on lexicon source consisted of original source, material, and pars proto whilee based on contextual were ordinary and magical, or religious. Later, it was used as regular drinking water, therapy water, and medication
\end{abstract}

Keywords: meaning, banyu, Banjar

\begin{abstract}
Abstrak
Penelitian ini mengkaji tentang bagaimana aplikasi makna mitos Banyu pada bahasa banjar berdasarkan sumber leksikon dan kontekstual. Tujuan penelitian meliputi deskripsi aplikasi makna mitos banyu pada bahasa banjar berdasarkan sumber leksikon dan fungsi Banyu dalam bahasa Banjar berdasarkan kontekstual. Metode yang digunakan adalah deskrieptif kualitatif. Teknik pengambilan data adalah simak dan libat cakap. Langkah kerja adalah pengumpulan data, pengolahan data, dan hasil analisis data. Teknik pengambilan sampel yang digunakan dalam tulisan ini adalah purposive sampling, yaitu teknik pengambilan sampel sumber data yang mempertimbangan waktu pengambilan data pada bulan Januari sampai bulan desember 2017. Tempat pengambilan data di Desa Padang, Kabupaten Banjar. Penyajian data menggunakan kata-kata biasa. Hasil penelitian aplikasi makna mitos banyu pada bahasa banjar berdasarkan sumber leksikonnya terdiri atas sumber asal, bahan, dan pars proto, sedangkan berdasarkan konstektual bersifat biasa dan magis, atau religi. Ada yang difungsikan sebagai air minum biasa, terapi, dan pengobatan.
\end{abstract}

Kata-kata Kunci: makna, banyu, Banjar

\section{PENDAHULUAN}

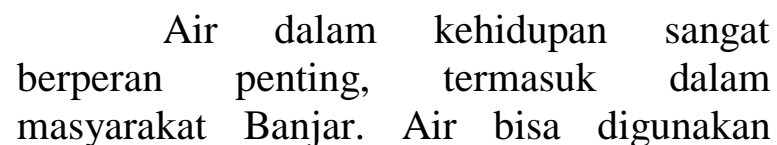
dalam kehidupan sehari seperti untuk keperluan rumah tangga maupun pengobatan. Tentu, air untuk keperluan rumah tangga berbeda dengan air untuk pengobatan. Dalam artian, air untuk pengobatan harus diolah dengan berbagai cara dan dari berbagai sumber yang bersifat magis atau religi. Bahasa Banjar air adalah banyu. Tim (tim, 2008:19) menyatakan banyu adalah air.

Berdasarkan hal ini, sumber pengolahan air yang terdapat dalam masyarakat Banjar beragam namanya. Hal ini dapat diketahui lagi secara jelas apabila dilihat dari segi fungsinya. Apabila diketahui nama air berdasarkan sumber pengolahan dan fungsi serta kapan ujaran yang mengandung kata air diketahui, maka akan mudah pula diketahui makna air secara keseluruhan. 
Kajian yang berkaitan dengan makna sebuah kata dan kalimat dalam penelitian disebut dengan semantik. Makna akan diketahui apabila diketahui unsur leksikal pembentuk kata merefensikan apa saja. Melalui referensi dapat dikaitkan dengan kehidupan masyarakat penutur akan diketahui lagi makna asosiasinya.Di tambah dengan penggunaan kata tersebut dalam ujaran dengan segala elemen konteks yang mendukung, maka akan semakin menambah pengetahuan tentang makna sesungguhnya secara keseluruhan dari kata tersebut. Muhajir (2014:245) menyatakan ekspresi linguistik dengan elemen makna yang terdapat dalam sebuah tuturan akan dapat diketahui melalui kajian semantik, seperti makna leksikal dan gramatikal, kontekstual, dll.

dalam $\begin{gathered}\text { Selama ini kajian tentang makna } \\ \text { bahasa }\end{gathered}$ daerah banyak
dilakukan.Namun jelas memiliki objek dan sudut pandang yang berbeda berdasarkan teori yang berbeda pula.. Hasil penelitian tersebut sangat bermanfaat bagi masyarakat luas untuk memberikan pemahaman tentang makna-makna tertentu dalam kata dan kalimat bahasa daerah.

Penelitian ini mengkaji tentang 1) bagaimana aplikasi makna mitos banyu pada bahasa banjar berdasarkan sumber leksikonnya.2) bagaimanakah aplikasi makna banyu pada bahasa banjar berdasarakan konstektual. Tujuan penelitian meliputi 1) pendeskrepsian aplikasi makna mitos banyu pada bahasa banjar berdasarkan sumber leksikonnya.2) pendeskrepsian aplikasi makna banyu pada bahasa banjar berdasarakan konstektual.

Penelitian tentang makna pernah dilakukan oleh Nengsih (2016) berjudul Makna Ungkapan Idiomatik dalam Kisdap Julak Ahim karya Jamal T.Suryanata. Dia membahas tentang makna idiom penuh dan sebagian dengan objek dalam cerita pendek . Sementara itu, kajian yang menggunakan teori semantic lainnya adalah Mubarok (2017) dengan judul Metafora Sayang pada
Kognisi Remaja Banjar. Dia membahas tentang makna sayang menurut versi remaja Banjar. Sitanggang (2013) meneliti Menilik Realitas Aspek Ekonomi-Sosial Masyarakat Kubu dalam Metafora Bahasa Suku Kubu di Jambi.Ketiga penelitian ini memiliki objek berbeda dengan yang peneliti lakukan.

\section{LANDASAN TEORI}

Kata banyu dalam tuturan pada masyarakat Banjar memiliki beragam makna. Makna tersebut tergantung pada wacana kalimat yang menggunakan kata banyu tersebut. Lubis 2015:27) menyatakan bahwa wacana adalah kesatuan bahasa lisan atau tulis baik panjang atau pendek. Wacana ini terdiri atas satu kesatuan semantik, ide, dan gramatikal. Jadi, kesatuan ini tidak hanya lantaran bentuk tetapi kesatuan arti. Untuk mengetahui kesatuan tersebut, sesesorang kala berinteraksi penting memahami hal-hal yang berkaitan dengan sistem bahasa, leksikon, semantik dan latar sosial budaya pembentuk wacana.

Djajasudarma

(2009:3--245)

menyatakan semantik berkisar pada hubungan ilmu makna itu sendiri di dalam linguistik, meskipun faktor nonlinguistik ikut mempengaruhi sebagai fungsi bahasa yang nonsimbolik. Semantik juga adalah studi tentang ilmu bahasa yang membedakan bahasa dengan proses mental atau simbolisme dalam aktivitas bicara. semantik merupakan kajian tentang makna yang melibatkan tema, ide, atau maksud. Parera (2014:51) menyatakan bahwa batasan liputan semantik berhubungan dengan semua ujaran dalam bahasa yang bermakna dan hubungan-hubungan makna yang dikandung oleh ujaran itu. Tarigan (2009:3) menyatakan bahwa semantik menelaah hubungan tanda dengan objek yang merupakan wadah penerapan tanda -tanda tersebut.

Terdapat variasi makna yang bisa dikaji dalam tataran semantik seperti makna deskriptif, denotatif, gramatikal, kontekstual, Pateda (2010:99-103) menyatakan makna 
deskriptif disebut pula makna kognitif atau makna referensial.Artinya makna tersebut terkandung di setiap kata dilambangkan oleh bahasa itu sendiri. Contoh kata air memiliki makna benda cair yang digunakan untuk minum, mandi, mencuci, dan lain-lain.

Makna gramatikal (imbuhan) adalah makna fungsional atau makna struktural yang muncul akibat berfungsinya kata dalam kalimat. Makna ini berhubungan dengan imbuhan yang melekati kata dasar.

Makna asosiasi adalah tautan makna dalam pikiran seseorang dengan barang lain.Terdapat tautan antara gagasan, ingatan, dan kegiatan pancaindra.Asosiasi berkaitan dengan kata yang memiliki hubungan dengan luar bahasa.Makna asosiasi berhubungan dengan nilai budaya masyarakat setempat dimana bahasa yang diasosiasikan berasal. (Suwandi, 2011:91).

Makna berikutnya adalah makna kontekstual dan kiasan.Makna yang muncul akibat hubungan antara ujaran dan konteks.Konteks di sini meliputi konteks orang, situasi, tujuan, suasana hati, waktu, tempat, objek yang dibicarakan,dan konteks kebahasaan (Pateda, 2010:119).

Berikutnya makna kiasan.Makna ini berkaitan dengan peribahasa atau ungkapan. (Pateda, 2010:108). Kridalaksana (2008:103) menyatakan makna kiasan disebut juga dengan makna idiom yaitu pemakaian kata yang maknanya tidak sebenarnya. Berkaitan dengan makna idiom, Verhar (2010:393) menyatakan bahwa idiom adalah makna kiasan yang disebut dengan nonkanonik yakni makna yang bukan berasal dari makna harfiah, artinya makna yang dihasilkan bukanlah makna sebenarnya. Menurut Djajasudarma (2009 : 20), idiomatik yakni leksikal yang berbentuk dari sekian banyak kata. Kata-kata yang disusun bersama kombinasi kata lain sanggup serta membuahkan makna yang tidak serupa. Dengan kata lain gabungan kata tersebut telah mempunyai makna tersendiri yang berbeda bersama makna kata pembentuknya dan bila digabung dengan kata lain sehingga maknanya dapat beralih. Arifin (2009:53) menyatakan idiom merupakan ungkapan yang mempunyai konstruksi yang khas terhadap sebuah bahasa yang salah satu unsurnya tak bakal dihilangkan atau ditukar.

\section{METODE PENELITIAN}

Selanjutnya, mengingat penelitian ini berkaitan dengan makna kata yang bisa diketahui secara apa dan akurat adanya setelah melihat konteks, maka metode yang digunakan adalah deskreptif kualitatif. Djajasudarma (2010:54) mengatakan bahwa data yang digunakan harus bersifat akurat dan alamiah. Data yang dihasilkan berupa deskripsi penggunaaan bahasa penuturnya.

Teknik pengambilan data adalah simak dan libat cakap.langkah kerja adalah pengumpulan data, pengolahan data, dan hasil analisis data.Teknik pengambilan sampel digunakan dalam tulisan ini adalah pengambilan sampel purposive sampling, yaitu teknik pengambilan sampel sumber data dengan pertimbangan tertentu (Sugiyono, 2009:300). Penetapan sampel tidak didasarkan keterwakilan dalam hal jumlah responden (besar sampel), tetapi berdasarkan kualitas atau ciri-ciri responden yang ingin diwakili.

Waktu pengambilan data adalah bulan Januari 2017 sampai dengan bulan Desember 2017. Tempat pengambilan di Desa Padang, Kabupaten Banjar.Penyajian data dengan menggunakan kata-kata biasa.

\section{PEMBAHASAN}

\section{Aplikasi Makna Mitos Banyu pada Bahasa Banjar berdasarkan sumber leksikonnya}

Aplikasi bentuk makna mitos banyu pada bahasa banjar berdasarkan sumber leksikonnya dapat diketahui berdasarkan analisis semantik. Terdapat sepuluh data tuturan yang menggunakan kata Banyu dalam komunikasi yang dilakukan oleh penutur bahasa Banjar. 
Totobuang, Vol. 6, No 1, Juni 2018: 59—68

\section{a. Bentuk makna banyu yang berdasarkan asal tempat}

\section{[1] Banyu burdah}

"Air Burdah"

Banyu Burdah "Air Burdah" terdiri atas dua kata pada data [1]. Air memiliki makna leksikal benda cair . Burdah adalah sebuah aktivitas dalam kehidupan masyarakat Banjar yang berkaitan dengan pembacaan syair-syair puji-pujian untuk nabi.Dengan demikian secara asosiasi air burdah merupakan nama kiasan dari sebuah benda cair yang diperoleh dari asal aktivitas bernama burdah.Menurut kajian semantik, penyebutan nama yang disandingkan dengan asal tempat akan membentuk nama baru dengan makna kiasan.

\section{[2] Banyu Sapar \\ "Air Sapar"}

Banyu Sapar "Air Sapar" dalam bahasa Banjar terdiri atas kata banyu "air" dan Sapar "Sapar". Air memiliki makna leksikal benda cair. Sapar"Sapar" adalah bulan sebelum Ramdhan. Berdasarkan hal ini, bentuk makna Banyu sapar "Air Sapar" ini berasal dari nama air yang dibuat di bulan Sapar.

Data [1] dan [2] ini sesuai dengan apa yang dimaksudkan oleh Sudaryat (2009:78) . Dia menyebutkan, bentuk makna kiasan dapat dihasilkan dari penyebutan berdasarkan tempat dan asal. Penyebutan ini berupa nama atau sebutan yang berasal dari nama tempat.Chaer (2009:48) menyatakan bahwa penyebutan sebuah nama berdasarkan daerah asal akan membentuk makna baru dari sebuah kata.

\section{[3] Banyu sungai}

"Air Sungai"

Banyu sungai "Air Sungai" terdiri atas dua kata dalam tada [3]. Banyu memiliki makna leksikal benda cai. Sungai memiliki makna leksikal, wadah air mengalir di alam secara alami.Dengan demikian air sungai adalah air yang berasal dari tempat air tersebut mengalir yaitu sungai.

\section{b. Bentuk makna banyu yang berdasarkan asal bahan}

\section{[4] Вапуи Виуи}

"Air Buyu"

Banyu buyu "Air buyu" dalam bahasa Banjar terdiri atas kata banyu "air" dan buyu "buyu". Air memiliki makna leksikal benda cair. Buyu"Buyu" secara makna asosiasi, dalam kehidupan masyarakat Banjar berkaitan dengan siluman ular pengisap darah yang berasal dari alam gaib.Dengan demikian arti makna dari Banyu buyu "Air buyu" dibentuk dari kata Banyu "air" yang berasal dari buyu "Buyu". Meskipun dalam kenyataannya, air tersebut direndam dalam rendaman kullit ular sanca. Oleh masyarakat tradisional Banjar, ular sanca dianggap sebagai simbol buyu "buyu" yang berasal dari alam gaib.

\section{[5] Banyu pidara}

"Air Pidara"

Banyu pidara "Air Pidara" dalam masyarakat Banjar terdiri atas kata banyu"air" dan pidara"pidara". Air memiliki makna leksikal benda cair. Pidara"pidara" adalah nama salah satu tumbuhan.Secara asosiasi, apabila masyarakat Banjar mendengar nama ini maka logika mereka akan mengatakan bahwa air tersebut dibuat dari rendaman daun pidara.Dengan demikian secara semantik, bentuk nama mitos Banyu pidara "Air Pidara" artinya air yang berasal dari daun pidara.

[6] Banyu tih

"Banyu teh"

Banyu tih "Banyu teh" terdiri atas kata banyu "air" dan tih"teh". Air memiliki makna leksikal benda cair. Teh secara 
leksikal adalah salah satu nama tanaman.Air the secara asosiasi memiliki makna air yang dibuat dari rendaman daun the.Kebiasaan masyarakat Banjar, air ini biasanya disuguhkan kala ada tamu atau saat menyamil sesuatu..

Data [3] dan [4] ini sesuai dengan apa yang dimaksudkan Sudaryat (2009:78). . Dia menyetakan penyebutan nama kiasan dapat berdasarkan bahan. Nama atau sebutan yang berasal dari bahan benda itu. Chaer (2009:49) menyatakan bahwa ada sejumlah benda yang namanya diambil dari nama bahan pokok benda itu.

\section{c. Bentuk makna banyu yang berdasarkan pars pro toto}

\section{[7] Banyu Singgugut}

"Air Singgugut"

Banyu Singgugut "Air Singgugut" terdiri atas dua kata banyu "air" dan singgugut "singgugut". Air memiliki makna leksikal benda cair. Singgugut "singgugut" berdasarkan kepercayaan masyarakat merupakan nama penyakit. Jadi Secara asosiasi berhubungan dengan air yang sudah dibaca-bacai ayat suci oleh ulama untuk menghilangkan penyakit singgugut. Makna pada data [8] diketahui setelah kata kiasan tersebut diparafrasakan, menjadi air yang dibuat untuk pengobatan singgugut.

\section{[8] Banyu Palungsur}

"Air pelungsurr"

Banyu Palungsur "Air pelungsur" terdiri atas dua kata air dan pelancar. Iar secara leksikal berkaitan dengan benda cair.Palungsur Secara asosiasi berhubungan dengan kegiatan melancarkan. Berdasarkan kenyataanya, air ini dibuat oleh ulama yang memiliki manfaat sebagai air untuk memperlancar proses bersalin. "Air pelungsurr" pada data [8] digunakan untuk mewakili cerita tentang air pelancar melahirkan.

\section{[9] Banyu Yasin}

"Air Yasin"

Banyu Yasin "Air Yasin" terdiri atas kata Banyu"air" dan Yasin"Yasin". Banyu secara leksikal memiliki makna benda cair.Yasin secara leksikal buku bernama Yasin.Secara asosiasi, air ini dihasilkan dari bacaan ayat-ayat yasin.Dengan demikian, Bentuk ini dihasilkan dari penggunaan dua kata untuk mewakili cerita tentang air tersebut.

Data [7], [8], dan [9] sesuai dengan apa yang dimaksudkan Sudaryat (2009:78)..Asal penyebutan idiom pars pro toto adalah untu penyebutan sebagian dari seluruh anggapan. Gejala ini sering disebut pars pro toto yakni sebagian untuk keseluruhan. Gejala itu terjadi karena kita tidak mampu menyebut barang secara keseluruhan dan terperinci tetapi hanya ciri yang khusus saja. Contohnya: Gedung gajah dari gedung yang didepannya ada patung gajah. Gedung sate dari gedung yang atapnya memimiliki hiasan seperti tusuk sate, dan baju hijau dari kebiasaan tentara yang suka berbaju hijau (tentara) .

\section{Aplikasi Makna Banyu pada Bahasa Banjar berdasarakan Konstektual}

Makna berikutnya adalah makna kontekstual dan kiasan.Makna yang muncul akibat hubungan antara ujaran dan konteks.Konteks di sini meliputi konteks orang, situasi, tujuan, suasana hati, waktu, tempat, objek yang dibicarakan, dan konteks kebahasaan.(Pateda,2010:119). Berdasarkan hasil analisis data diketahui lebih lanjut tentang makna banyu"air" secara kontekstual.

\section{Data [1]}

Banyu burdah tuh kita pakai gasan si Aluh kalu mandi tujuh bulanan.

"Air burdah itu kita gunakan untuk si Aluh ketika mandi tujuh bulanan" 
Konteks terjadi antara ibu dan ayah Aluh dalam rumah keluarga Banjar. Mereka sedang membicarakan tentang fungsi air pada data [1] yang bisa digunakan untuk si anak yang bernama Aluh. Aluh kala itu sedang hamil menjelang tujuh bulan. Suasana rumah kala itu dalam situasi santai .Keluarga tersebut berasal dari masyarakat di pedesaan Banjar.

Berdasarkan konteks, Data [1] tidak sekedar air yang terdiri atas makna benda cair yang diperoleh dari kegiatan burdah. Akan tetapi ada makna kontekstual lainnya. Pada masyarakat Banjar menggunakan air ini sebagai air pelindung bagi janin yang baru tumbuh di rahim perempuan tujuh bulanan. Hal ini dapat dilihat pada tuturan data [1].

Banyu burdah tuh kita pakai gasan si Aluh kalu mandi tujuh bulanan "Air burdah itu kita gunakan untuk si Aluh ketika mandi tujuh bulanan"

Dengan demikian berarti, data [1] menjadi bagian dari pengobatan bagi masyarakat Banjar.Air ini diharapkan akan membawa kebaikan baik terhadap ibu yang hamil maupun bayi yang dikandungnya.Tuturan pada data [1] menyatakan tentang salah satu makna banyu"air" dalam kebudayaan tradisional Banjar.

Jadi, data [1] memiliki makna secara kontekstual adalah air yang dibuat pada kegiatan burdah. Kegiatan burdah adalah kegiatan keagamaan yang berhubungan dengan pembacaan puji-pujian kepada nabi. Air ini memiliki fungsi antaralain sebagai pelindung bagi janin yang memasuki usia tujuh bulanan.

\section{Data [2]}

Lakasi kita maulah Banyu Sapar, maka sapar parak hudah

"Cepat ya kita membuat Air Sapar, maka sapar dekat sudah"
Konteks tuturan terjadi pada sebuah pasangan suami istri. Petutur adalah ayah dari beberapa anaknya. Dia membuat kalimat yang menggunakan data [2] sebagai perintah kepada istrinya. Saat perbincangan terjadi, waktu itu sudah masuk bulan Sapar.Sebentar lagi menjelang Ramadhan.

Berdasarkan konteks ini, data [2] tidak hanya memiliki makna air yang dibuat pada bulan Sapar.Terdapat makna yang lainnya. Makna tersebut berhubungan dengan kebiasaan bagi masyarakat Banjar untuk membuat air sapar secara bersamaan.Masyarakat Banjar termasuk masyarakat yang sebagaian masih mempercayai kebiasaan tradisional harus tetap dilaksanakan.

Jadi, data [2] memiliki makna secara kontekstual adalah air sapar biasanya dibuat pada bulan sapar dengan cara satu keluarga atau beramai-ramai membaca ayat-ayat penolak bala. Biasanya dibuat pada hari Rabu menjelang akhir bulan Sapar. Air ini akan diminum bersama-sama untuk menambah kekbalan tubuh agar terhindar dari marabahaya di bulan tersebut.

Di kalangan masyarakat Banjar ada mitos bahwa hari Rabu terakhir di bulan Safar adalah hari berbahaya. Pada hari itu para pemilik ilmu hitam akan melepas ilmu hitamnya. Sehubungan dengan itu, semua orang harus menghindarinya dengan berbagai cara, salah satunya dengan membuat bayu sapar "air sapar" (Gani, 2015:11).

Data [3]

Banyu sungai tih rigat banar

"Air Sungai lihat kotor sekali"

Konteks tuturan terjadi pada seorang kakak kepada adiknya. Saat itu mereka sedang duduk di tepi sungai belakang rumah. Sungai yang selama ini mereka gunakan sebagai bagian dari ragam aktivitas keseharian, saat itu terlihat kotor sekali, dipenuhi sampah dan warna coklat begitu 
kental. Penutur, yaitu si kaka mengujarkan kalimat yang mengandung kata sungai .

Berdasarkan konteks ini, makna air sungai adalah air yang mengalir di sungai. Di kalngan masyarakat Banjar pada umumnya terbiasa hidup dengan menggunakan air sungai. Sehubungan dengan makna air sungai dalam kalimat pada data [3] ini menggunakan makna air sungai secara langsung. Frasa ini bisa langsung dipahami oleh para pendengar.

Pada data [3] penutur hanya memberitahukan kepada mitra tutur tentang air sungai yang kotor. Dalam kalimat ini tidak tujuan perintah atau bertanya tentang info yang disampaikan oleh petutur. Mitra tutur juga tidak memberikan tanggapan serius saat itu, dia hanya menganggukan kepala saja setelah mendengar apa yang dinyatakan penutur.

Jadi, secara kontekstual, data [3] memiliki makna air yang asalnya dari sungai. Air ini menjadi sumber kehidupan bagi masyarakat di sekitar. Air ini bisa untuk minum, cuci, dan salah satu jalur transportasi antardesa.

\section{Data [4]}

Anak ikam tuh pinanya diisap buyu, mintaakan pang banyu Buyu lawan julak Utuh

"Anak kamu itu sepertinya diisap Buyu, mintakan dong air Buyu dengan Uak Utuh.

Konteks pada data [4] terjadi antara dua orang tetangga. Penutur melihat anak yang digendong mitra tutur terlihat kurus sekali dan menurut mitra tutur, ketika dia memeriksakan ke puskesmas telah dinyatakan dokter kurang gizi. Melihat keadaan tersebut, petutur mengujarkan kalimat seperti data [4].

Dalam masyarakat Tradisional, ada kepercayaan anak yang sering sakit-sakitan dan terlihat kurus tidak berdaya, maka anak tersebut dianggap sebagai Buyu. Buyu dianggap ular gaib yang senang mengisap anak kecil sehingga sering sakit-sakitan. Dalam menangani anak yang seperti itu, masyarakat tradisional Banjar akan meminta banyu buyu kepada orang pintar. Biasanya setelah dimandikan, anak tersebut akan sehat kembali.

Jadi, data [4], secara kontekstual memiliki makna air yang memiliki fungsi sebagai pengobatan tradisional. Air ini diperoleh dari hasil rendaman ular sanca. Penyakit yang mesti disembuhkan dengan air ini dianggap berasal dari isapan ular siluman.

Data [5]

Hari ini, mun inya masih panas haja, kita mandii jalah lawan banyu pidara wadah nining Aluh.

"Hari ini kalau dia masih panas saja, kita mandii sajaah dengan air pidara di tempat Nenek Aluh”.

Konteks yang terjadi pada data [5] adalah penutur seorang ibu . Dia melihat cucunya panas terus-terusan sejak tiga hari yang lalu. Melihat hal tersebut, penutur lalu mengujarkan kalimat sebagaimana data [5].

Mitra tutur pun mengiyakan apa yang disuruh penutur. Penutur memang memberikan perintah kepada mitra tutur untuk meminta air pidara kepada Nenek Aluh. Nenek Aluh pada masyarakat di sana dianggap orang pintar yang bisa membuat air pidara.

Masyarakat tradisional Banjar memiliki kepercayaan jika seorang anak kecil suhu badannya panas secara terus menerus, hal itu dianggap akibat perbuatan mahluk halus yang jahat. Mahluk halus tersebut akan mengganggu anak kecil dengan berbagai cara, apakah dengan cara menampakkan diri atau sekadar menegur si anak.

Anak kecil yang mengalami kondisi tersebut akan ditanggulangi dengan cara dimintakan air pidara. Air tersebut lalu dimandikan oleh yang membuat air. 
Biasanya si anak akan sembuh seperti sedia kala.

Jadi, secara kontekstual data [5] ini memiliki makna air yang memiliki fungsi untuk menyembuhkan anak-anak yang badannya panas terus menerus. Air ini dibuat oleh orang pandai membuatnya. Anak yang panas terus menerus dalam masyarakat Banjar dikenal dengan "kapidaraan".

Data [6]

\section{Banyu tih nih manis banar}

"Banyu the ini manis sekali"

Konteks ini terjadi antara seorang suami kepada istrinya. Saat itu dalam suasana santai di sore hari. Suami istri tersebut duduk di beranda rumah sambil makan camilan.

Makna dalam frasa ini bersifat langsung dipahami oleh para pendengar pada umumnya. Banyu yang artinya air berasal dari rendaman teh yang sudah diolah menjadi serbuk. Bagi masyarakat Banjar meminumteh adalah bagian dari keseharian mereka kala akan menikmati hidangan tertentu.

Secara kontekstual data [7] memiliki makna air tawar yang diberi rendaman daun teh. Air tersebut bukan untuk pengobatan, akan tetapi digunakan oleh masyarakat Banjar sebagai air minum saat makan sesuatu.

\section{Data [7]}

Banyu Singgugut nih capati dimnum, nyaman kada sakit parut lagi.

"Air Singgugut ini cepat diminum, biar tidak sakit perut lagi"

Konteks yang terjadi pada tuturan ini adalah ujaran yang keluar dari ucapan seorang nenek kepada cucunya. Saat itu cucunya sedang kesakitan memegang perutnya. Nenek tersebut memerintahkan sekaligus menyerahkan botol berisi air singgugut kepada cucu perempuannya tersebut.
Air ini biasanya dibuat untuk mengobati seoran perempuan yang memiliki penyakit perust yang diindapnya. Menurut kepercayaan orang Banjar tradisional, penyakit perempuan tersebut diakibatkan hewan gaib bernama singgugut. Untuk menanggulangi penyakit tersbut dibuatlah air penawarnya.

Air singgugut dibuat dari air tawar yang dibuat oleh seorang yang memang pandai membuat air ini melalui bacaan tertentu. Air tadi kemudian diminumkan kepada si penderita. Biasanya penderita akan merasakan khasiatnya. Penyakit perutnya pun sembuh.

Jadi, secara kontekstual data [7] memiliki makna air yang digunakan untuk menyembuhkan penyakit singgugut. Air ini dibuat oleh yang ahlinya. Penyakit ini dimiliki oleh perempuan yang mendapatkan singgugut tersebut, berupa hewan gaib yang berbentuk cicak berada dalam perutnya.

Data [8]

Banyu Palungsur nih kaina ikam minumlah

"Air pelungsur ini nanti kamu minum ya"

Konteks ini terjadi antara seorang suami dengan istrinya. Suaminya sangat memperhatikan sang istri yang saat itu dalam kondisi mengandung. Agar kelahirannya lancar, sang suami sudah mencarikan air pelancar kelahiran.

Masyarakat Banjar tradisional mempercayai akan adanya air pelancar. Pembuat air tidak orang sembarangan. Biasanya setelah meminum air tersebut, kelahiran pun akan lancar.

Makna kontekstual dalam data [8] adalah air tersebut digunakan untuk melancarkan proses kelahiran. Masyarakat tradisional Banjar sangat akan khasiat air tersebut. Air palungsur dibuat oleh seseorang yang ahli di bidang itu.

Data [9] 
Banyu Yasin nih sudah mama ulahakan, nginum isuk ulangan nakai "Air Yasin ini, sudah mama bikinkan, minum besok ulangan Nak"

Konteks ini dituturkan oleh seorang ibu kepada anaknya. Saat itu si anak sedang belajar sebab besok hari harus mengikuti ulangan harian. Setelah petutur selesai mebuat air yasin, dia pun memberikan air tersebut kepada anaknya sambil berujar seperti data [9]

Kabiasaan masyarakat Banjar yang tidak lepas dengan ajaran Islam ini adalah membuat air yasin. Air yasin adalah air yang dibuat seseorang dengan membacakan ayatayat yasin pada segelas atau seteko air tawar. Air ini difungsikan untuk berbagai tujuan.

Dalam konteks di atas air yasin digunakan untuk membuat si anak terang hati dan pikirannya. Seorang ibu bisa membuat air yasin untuk kepentingan anaknya. Melalui air ini harapannya apa yang diinginkan akan tercapai.

Jadi, makna kontekstual pada data [9] adalah air tersebut hasil dari air tawar yang dibacakan ayat yasin oleh siapa saja. Air ini disebut air yasin. Gunanya beragam, bisa untuk menyembuhkan penyakit tertentu atau untuk menerangkan pikiran.

\section{PENUTUP}

Aplikasi makna mitos banyu pada bahasa banjar berdasarkan sumber leksikonnya terdiri atas sumber asal, bahan, dan pars pro toto. Aplikasi makna banyu pada bahasa banjar berdasarkan konstektual dapat bersifat biasa dan magis, atau religi. Ada yang difungsikan sebagai air minum biasa, air tawar biasa, dan untuk pengobatan.

Penelitian tentang banyu sangat menarik untuk dikaji darai segi maknanya. Alangkah menariknya jika kata banyu ini biasa diteliti dengan contoh yang lebih banyak lagi. Semoga peneliti lain yang tertarik dengan kata banyu dengan maknanya ini dapat menjadikan materi ini sebagai salah satu refrensi.

\section{DAFTAR PUSTAKA}

Arifin, E. Zainal dan Tasai, S.Amran. 2009. Cermat

Berbahasa

Indonesia.Jakarta: Akademika presindo.

Chaer, Abdul. 2009. Pengantar Semantik Bahasa Indonesia. Jakarta: Rineka Cipta.

Chaer, Abdul. 2009. Pengantar Semantik Bahasa Indonesia. Jakarta: Rineka Cipta.

Djajasudarma, T. Fatimah. 2009. Semantik I. Bandung:Refik.

2010. Metode

Linguistik; Ancangan Metode Penelitian dan Kajian. Bandung. PT Eresco.

Kridalaksana Harimurti. 2008. Kamus Linguistik. Jakarta: Gramedia.

Lubis, Hamid Hasan. 2015. Analisis Wacana Pragmatik. Bandung: Angkasa.

Martina dan Febrianti, B.K. 2015. "Mengungkap Pemaknaan dalam Tradisi dan Budaya Pernikahan Sambas (tinjauan Semantik)": Dalam Jurnal Tuah Talino IX (9) : Hal. . 25--35. Kalimantan Barat.

Mubarok, Ahmad. 20017. Metafora sayang dalam kognisi remaja Banjar. Jurnal undas 13 (2). Hal. 154-164 Banjarbaru. Balai Bahasa Kalimantan Selatan.

Muhajir. 2016. Semantik dan Pragmatik. Pustaka Mandiri: tanggerang

Nengsih, Sriwahyu. 2016. Makna Ungkapan Ideomatik dalam Kisdap Julak Ahim Karya Jamal T Suryanata. Bunga Rampai Bahasa (hlm. 1-27). Banjarbaru: Balai Bahasa.

Parera, J.D. 2014. Teori Semantik. Erlangga:Jakarta.

Pateda, Mansoer. 2010. Semantik Leksikal. Jakarta. Rineka Cipta.

Sitanggang, Natal P. 2013. Menilik Realitas Aspek Ekonomi-Sosial Masyarakat 
Totobuang, Vol. 6, No 1, Juni 2018: 59—68

Kubu dalam Metafora Bahasa Suku Kubu di Jambi. Jurnal Jalabahasa. 9 (2). Hal 37--48). Semarang: Balai Bahasa Provinsi Jawa Tengah.

Sudaryat, Yayat. 2009. Makna dalam wacana. Bandung:Yrama Widya.

Sugiyono. 2009. Metode Penelitian. Bandung: Alfabeta
Suwandi, Sarwiji. 2011. Semantik Pengantar Kajian Makna. Yogyakarta: Media. Tarigan. Henry Guntur. 2009. Pengajaran Semantik. Angkasa:bandung Verhaar, JWM. 2010. Asas-asas Linguistik. Yogyakarta: Gadjah Mada University Press. 


\begin{tabular}{|lcc|}
\hline & TOTOBUANG & \\
\hline Volume 6 & Nomor 1, Juni 2018 & Halaman 69-80 \\
\hline
\end{tabular}

\title{
KAJIAN LATAR FISIK DAN LATAR SOSIAL YANG TERCERMIN DALAM NOVEL PERTEMUAN DUA HATI KARYA NH. DINI (A review of the physical background and social setting that is reflected in the novel of "Pertemuan Dua Hati" by NH. DINI)
}

\author{
Sakila \\ SMP Negeri 2 Singkawang \\ Jalan Pahlawan, Kota Singkawang, Indonesia \\ Pos-el: sakilaspd@yahoo.co.id
}

(Diterima: 6 Februari 2018; Direvisi 24 Mei 2018; Disetujui: 30 Mei 2018)

\begin{abstract}
The purpose of this study commonly described about the background of the Pertemuan Dua Hati novel and specifically interpreted its physical background and social setting. The research used descriptive method with qualitative research model. The research approach was using structural approach. The source of the data was taken from a novel entitled Pertemuan Dua Hati by Nh. Dini which had been published by PT Gramedia Pustaka Utama, Jakarta, in 1992, the sixth printing, and consists of 85 pages. Based on the analysis, it concluded that the physical setting that presented by the author was quite well. This can be seen from the description of the house and the area. Furthermore, the social background that presented by the author was good enough. It has been explanated from the conditional economy, the views of life and the attitude of the character.
\end{abstract}

Keywords: Novel, Pertemuan Dua Hati, physical setting, social setting.

Abstrak

Tujuan penelitian ini secara umum adalah untuk mendeskripsikan latar dalam novel Pertemuan Dua Hati, sedangkan secara khusus untuk menginterpretasikan latar fisik dan latar sosial novel tersebut. Metode penelitian yang digunakan adalah metode deskriptif dengan model penelitian kualitatif. Pendekatan penelitian yang digunakan adalah pendekatan struktural. Sumber datanya berasal dari novel yang berjudul Pertemuan Dua Hati karya Nh. Dini yang diterbitkan oleh PT Gramedia Pustaka Utama, Jakarta, tahun 1992, cetakan keenam, dan terdiri dari 85 halaman. Berdasarkan hasil analisis terhadap novel tersebut, latar fisik yang disajikan pengarang cukup baik. Hal ini terlihat dari keterangan mengenai rumah dan daerah. Selanjutnya, latar sosial yang disajikan pengarang cukup baik. Hal ini terlihat dari pemaparan tentang keadaan ekonomi, pandangan hidup, dan sikap hidup tokoh.

Kata-kata kunci: Novel, Pertemuan Dua Hati, latar fisik, latar sosial.

\section{PENDAHULUAN}

Sastra adalah ungkapan pribadi manusia yang berupa pengalaman, pemikiran, perasaan, ide, semangat keyakinan dalam suatu bentuk gambaran kongkrit yang membangkitkan pesona dengan bahasa sebagai alat (Sumardjo dan Saini, 1986:3).

Sastra sebagai ungkapan pribadi manusia yang bersifat imajinatif, dalam kehidupan sehari-hari dapat berfungsi untuk memperjelas, memperdalam, dan memperkaya pengalaman serta penghayatan yang lebih baik itu manusia dapat bersikap untuk menciptakan kehidupan yang sejahtera (Sumardjo dan Saini, 1986:16).

Salah satu bentuk karya sastra yang dapat mewakili seperti dikemukakan di atas adalah novel. Novel dapat berisi tentang sesuatu yang mungkin terjadi atau tidak sama sekali. Selain itu, novel juga merupakan salah satu sarana yang efektif atau media yang tepat untuk memahami kehidupan. Oleh karena itu, novel dengan cepat leluasa merefleksikan kenyataan dari berbagai kehidupan di masyarakat.

Bagian dari unsur yang membangun karya sastra, seperti novel adalah unsur latar. 
Latar merupakan salah satu bagian yang berperan penting dalam cerita rekaan. Latar yang digarap dengan baik sangat berpengaruh terhadap imajinasi pembaca. Selain itu, latar merupakan unsur karya sastra yang menjadi latar belakang segala peristiwa yang terjadi dalam karya sastra (Effendy, 1985:41). Latar juga berkaitan dengan nilai-nilai kehidupan manusia seperti adat-istiadat, norma, dan tingkah laku yang kesemuanya menjadi bagian kehidupan manusia.

Latar atau seting memiliki fungsi yang penting bagi sebuah novel. Kelemahan pada latar akan menimbulkan ketimpangan tensi dan emosi tokoh. Dikatakan demikian karena latar atau seting turut memberikan nuansa cerita.

Latar dalam novel antara lain terdiri dari latar fisik dan latar sosial. Latar fisik meliputi tempat dan daerah, sedangkan latar sosial meliputi keadaan ekonomi, pandangan hidup dan sikap hidup.

Novel yang tidak memiliki latar fisik membuat pembaca bertanya-tanya di mana tempat dan daerah terjadinya cerita tersebut. Begitu pula apabila novel tidak memiliki latar sosial akan menyebabkan pembaca menjadi bingung tentang sikap hidup sang tokoh atau pembaca berkesimpulan mungkin pengarang belum mampu menentukan pandangan hidup seorang tokoh dalam novel. Selanjutnya, dapat dikatakan bahwa pengarang yang berpengalaman adalah pengarang yang mampu melukiskan latar fisik dan latar sosial secara kongkret.

Mengingat pentingnya fungsi latar dalam novel, sehingga penelitian ini difokuskan pada latar, terutama latar fisik dan latar sosial. Hasil penelitian diharapkan dapat memberikan gambaran kongkrit tentang latar fisik dan latar sosial dalam sebuah novel. Selain itu, diharapkan dapat memaparkan interpretasi mengenai latar tersebut.

Novel Pertemuan Dua Hati yang selanjutnya disingkat PDH karya Nh. Dini adalah sebuah novel Indonesia modern yang mengisahkan tentang perjuangan seorang wanita. Seorang istri yang juga seorang ibu dari keluarga sederhana, bahkan sering kekurangan dalam memenuhi kebutuhan sehari-hari. Namun, ia tetap menciptakan keluarga yang harmonis dan bahagia. Dia juga seorang guru yang ikut membantu suaminya mengatasi kesulitan ekonomi keluarganya. Selain itu juga tentang perjuangannya merawat anak yang menderita epilepsi kronis. Pada saat pertama mengajar, langsung berhadapan dengan salah seorang muridnya yang mengalami kesulitan, murid tersebut bernama Waskito.

Dalam novel ini dikisahkan tentang perjuangan dan keuletan $\mathrm{Bu}$ Suci dalam membimbing dan mengembalikan Waskito menjadi anak yang wajar dan normal sampai akhirnya ia naik kelas.

Novel Pertemuan Dua Hati menyajikan kisah kehidupan seorang guru dan ibu dalam mendidik putra-putranya. Dengan membaca novel Pertemuan Dua Hati, guru dan orang tua akan semakin memahami tentang pendidikan anak-anaknya. Novel ini cukup selaras dibaca oleh kalangan pendidik, orang tua dan seluruh masyarakat.

Penulis merasa tertarik untuk meneliti karya Nh. Dini dengan pertimbangan bahwa: a) sebagai penulis, Nh. Dini sudah dikenal masyarakat sejak tahun 1950-an lewat karya pertamanya yang berjudul Dua Dunia (kumpulan cerpen, 1956). b) Nh. Dini telah menulis banyak buku sastra, berupa kumpulan cerpen, novel dan memoar. c) Penulis Nh. Dini merupakan penulis watak yang baik. Gerak-gerik kecil pelakunya dia tangkap dalam upaya memberikan gambaran watak yang lebih tepat. Pelukisan perasaan manusi dapat dilukiskan dengan baik. Nh. Dini selalu cermat dalam menggambarkan setiap tokoh, selalu lengkap dan mendalam. Pembaca diajak ikut dalam jalinan kalimat yang kreatif dan tidak klise.

Dihubungkan dengan kurikulum Bahasa dan Sastra Indonesia untuk SMP, penelitian tentang latar dalam novel sesuai dengan tuntutan KTSP yaitu membahas 
tema, dan latar yang terdapat dalam cerpen, novel, dan drama.

Berdasarkan uraian tersebut di atas, maka penulis tertarik untuk meneliti novel Pertemuan Dua Hati dengan mengkaji latar fisik dan latar sosialnya.

Berdasarkan latar belakang masalah yang telah disebutkan di atas, maka masalah dalam penelitian ini adalah bagaimanakah latar fisik dan latar sosial yang tercermin dalam novel Pertemuan Dua Hati karya Nh. Dini?

Sesuai dengan latar belakang masalah yang telah disebutkan di atas, tujuan penulisan laporan penelitian ini adalah untuk menginterpretasikan latar fisik dan latar sosial novel Pertemuan Dua Hati karya Nh. Dini.

Adapun manfaat penelitian ini adalah sebagai berikut :

1) Sebagai salah satu bahan acuan dalam mengajarkan materi apresiasi sastra. Terutama tentang latar dalam sebuah novel.

2) Sebagai bahan penunjang penelitian yang lain. Penelitian ini dapat membantu peneliti lain terutama yang mengkaji sastra novel dan tentang Nh. Dini.

\section{LANDASAN TEORI \\ Pengertian Novel}

Novel berasal dari bahasa Itali, juga dari bahasa Latin yakni novellus yang diturunkan pula dari kata novies yang berarti baru. Dikatakan baru karena kalau dibandingkan dengan jenis-jenis sastra lainnya seperti puisi, drama, dan lain-lain, maka jenis novel ini muncul kemudian (Tarigan, 1984:164).

Sastra dalam konteks ini novel adalah suatu karangan prosa yang bersifat cerita yang menceritakan suatu kejadian yang luar biasa dari kehidupan orang-orang (tokoh cerita) (Suroto, 1990: 19).

Menurut Fuadi (2016:132) novel adalah cerita atau prosa panjang yang mengandung rangkaian cerita kehidupan seseorang dan orang-orang di sekelilingnya dengan menonjolkan watak dan sifat setiap pelaku.

Selanjutnya Sumarjo dalam Sentosa dan Wahyuningtyas (2010:47) mengatakan bahwa novel diartikan sebagai novel adalah produk masyarakat. Novel berada di masyarakat karena novel dibentuk oleh anggota masyarakat berdasarkan desakandesakan emosional atau rasional dalam masyarakat.

Berdasarkan pengertian tersebut di atas dapat disimpulkan bahwa novel adalah salah satu bentuk karya sastra yang merupakan ungkapan pribadi pengarangnya berdasarkan pengalaman, pemikiran, perasaan, ide, semangat, serta keyakinan dalam suatu bentuk gambaran kongkret yang membangkitkan pesona dengan alat bahasa.

\section{Pengertian Latar (Setting)}

$$
\text { Menurut Sudjiman }
$$

mengartikan latar atau setting sebagai segala keterangan, petunjuk, pengacuan yang berkaitan dengan waktu, ruang dan suasana terjadinya peristiwa dalam suatu karya sastra. Pendapat ini sejalan dengan pendapat Abrams dalam Priyadi (1994:64) yang mengartikan latar sebagai tempat secara umum, waktu dan lingkungan sosial tempat terjadinya peristiwa. Siswandarti (2009:44) juga menegaskan bahwa latar adalah pelukisan tempat, waktu, dan situasi atau suasana terjadinya suatu peristiwa.

Robert Stanton dalam Priyadi (1994:64) mengatakan bahwa latar atau tandas tumpu adalah lingkungan tempat peristiwa terjadi. Latar tempat atau ruang yang diamati (kampus, kapal, kafetaria, penjara, Hongkong, Paris, dll) dan orang atau kerumunan orang di sekitar tokoh.

Sementara itu pendapat Jakob Sumardjo dalam Aeini (1995:25) mengemukakan bahwa latar adalah tempat bermain sebuah cerita. Latar bukan hanya terbatas pada pengertian geografis, tetapi juga antropologis. Lebih lanjut Sumardjo dan Saini (1991:76) mengatakan latar atau setting cerita bukan hanya menunjukkan 
tempat dan waktu tertentu tetapi juga hal-hal yang hakiki dari suatu wilayah, sampai pada debu pemikiran rakyatnya, kegilaan mereka, gaya hidup mereka, kecurigaan mereka dan sebagainya. Sehingga latar atau setting cerita bukan hanya menunjukkan tempat, waktu dan sarana dalam cerita seperti yang kita kira-kira sebelumnya, tetapi mencakup berbagai pola tingkah laku kehidupan masyarakat tertentu.

\section{Macam-macam latar}

Dari Pengertian latar sebagaimana disebutkan di atas, Hudson dalam Sudjiman (1991:44) membagi latar menjadi dua yaitu (1) latar material atau fisik dan (2) latar sosial. Latar material atau fisik dikukuhkan oleh hal-hal yang kongkret. Hal-hal yang kongkret merupakan hal yang visual, badaniah, teraba. Misalnya tempat tinggal, peralatan rumah tangga, bentuk kesenian, daerah dan lain-lain. Sedangkan latar sosial lebih bersifat abstrak. Misalnya konsep nilai dalam masyarakat, adat istiadat, kepercayaan, sistem politik, ekonomi, sikap hidup, pandangan hidup dan lain-lain (Priyadi, 1994:97).

Menurut Abrams dalam Aeini (1995:27) latar dapat dikategorikan menjadi latar sosial, latar tempat atau geografis, dan latar waktu atau historis.

Dari pendapat Marjorie Boulton, Lostracco, dan Wilkerson dalam Priyadi (1994:67) dapat disimpulkan bahwa latar ada dua yakni latar dalam pengertian yang sempit dan latar dalam pengertian yang luas. Dalam pengertian yang sempit, yang dimaksud dengan latar adalah tempat dan waktu terjadinya peristiwa. Sedangkan dalam pengertian yang luas, latar menunjuk pada keseluruhan lingkungan fisik, ekonomi, sosial (sistem kekerabatan, sistem religi dan lain-lain), politik, dan psikologi.

\section{METODE PENELITIAN}

Metode yang digunakan dalam penelitian ini adalah metode deskriptif. Metode ini digunakan untuk mendeskripsikan latar fisik dan latar sosial novel Pertemuan Dua Hati karya Nh. Dini.

Adapun model penelitian yang digunakan adalah penelitian kualitatif Bogdan dan Biklen dalam Semi (1993:24) menuliskan bahwa penelitian kualitatif bersifat deskriptif. Hal ini mengandung arti bahwa dalam melakukan kajian tidak menggunakan perhitungan angka-angka tetapi dipaparkan dengan menggunakan kata-kata berdasarkan data penelitian.

Selanjutnya sumber data berasal dari Novel Pertemuan Dua Hati karya Nh. Dini yang berjumlah 85 halaman, diterbitkan oleh PT Gramedia Pustaka Utama Jakarta merupakan cetakan keenam pada bulan Oktober 1992.

Pendekatan dalam penelitian ini adalah pendekatan struktural atau pendekatan analitik. Pendekatan ini bertolak dari asumsi dasar bahwa karya sastra sebagai karya kreatif memiliki otonomi penuh yang harus dilihat sebagai suatu sosok yang berdiri sendiri terlepas dari hal-hal lain yang berada di luar darinya (Semi, 1993:67).

Teknik dan alat pengumpul data yang digunakan dalam penelitian ini adalah teknik studi dokumenter. Yaitu dengan membaca secara berulang dan membuat catatan sesuai dengan permasalahan yang dirumuskan. Dengan kata lain dalam memecahkan masalah penelitian, peneliti merujuk pada literatur-literatur yang relevan dengan permasalahan penelitian.

Adapun langkah-langkah yang ditempuh dalam menganalisis data sebagai berikut :

1) Membaca novel Pertemuan Dua Hati karya Nh. Dini secara berulang-ulang untuk melakukan verifikasi.

2) Mendeskripsikan data. Data yang ada dipaparkan atau digambarkan apa adanya dengan menggunakan kata-kata secara jelas.

3) Interpretasi data. Data yang sudah dideskripsikan kemudian ditafsirkan berdasarkan masalah penelitian. Data penelitian diinterpretasikan untuk 
mengungkapkan latar fisik dan latar sosial novel Pertemuan Dua Hati karya Nh. Dini.

\section{PEMBAHASAN}

\section{Deskripsi Latar Fisik Novel Pertemuan Dua Hati}

Novel Pertemuan Dua Hati dimulai dari rumah yang dikontrak berukuran besar, kamarnya hanya ada dua, bentuk ruang tengah memanjang dengan kamar mandi, sumur dan kamar kecil ada di dalamnya.

Selanjutnya digunakan nama kota Purwodadi sebagai tempat aku yang bernama Bu Suci menjadi guru waktu itu. Hamper sepuluh tahun aku mengajar di kota kelahiranku. Sehingga beberapa bulan yang lalu suamiku dipindahkan perusahaannya ke kota besar ini.

Seperti kota-kota pesisir lain, Semarang sudah ku kenal ketika aku bersekolah disana. Kepadatan penduduk dikuasai pengaruh golongan Tionghoa. Sekolahku terletak di bagian kota atas yang dinamakan daerah candi. Untuk pergi ke kota bawah harus naik "daihatsu" sebutan kendaraan karena lazimnya mobil bermerek daihatsu.

Suamiku mendahului pindah ke Semarang. Hal tersebut karena kantor di kota memerlukan dia sebagai ahli mesin. Semarang sebagai kota pelabuhan merupakan pintu gerbang berbagai pengaruh. Kebiasaan dan tradisi yang dipertahankan oleh sekelompok masyarakat, dibagian bagian tertentu kota ini bercampur dengan kebiasaan baru. Rumah-rumah terlalu berdekatan. Rumah tetangga menyuarakan kaset-kaset secara bersamaan dengan lagu yang berbeda.

Rumah RT itu mentereng. Berhalaman luas. Tetapi itu bukan satu-satunya rumah bagus di dalam kampung kami yang baru. Sepintas lalu aku sudah melihat tempat kediaman lain yang mewah dan modern.

Sewaktu tinggal di Purwodadi, kami menempati setengah batu setengah kayu. Letaknya di pinggir jalan. Sepuluh tahun yang lalu jalan itu belum ramai. Ketika kami meninggalkannya, lalu lintas sudah sangat padat.

Daerah kami disebut orang daerah minus. Desa-desa mempunyai sawah, tetapi tidak pernah menghasilkan berlimpahlimpah. Rakyat berduyun-duyun meninggalkan kehidupan bercocok tanam. Semarang adalah kota yang digemari sebagai sasaran mencari nafkah.

Pindah ke Semarang, kami tinggal di daerah pinggiran kota. Dimasa sekolah, daerah itu masih merupakan pinggiran yang kosong, meskipun mulai berkembang perlahan menjadi perkampungan liar. Namanya Mrican. Terletak di kota sebelah tenggara.

Pada hari-hari tertentu, pasar ini juga menjadi pasar hewan. Bermacam-macam binatang ternak diperjualbelikan.

Setelah dua bulan di rumah baru, kami mapan. Ruang tengah yang panjang kujadikan ruang keluarga. Di pojok kuletakkan televisi. Di dekat dinding yang bertentangan ada seperangkat meja kursi untuk makan. Itu juga kami pergunakan sebagai tempat menggarap pekerjaan rumah, menulis atau menjahit. Di depan televisi kugelar tikar pandan anyaman dua permukaan yang di daerah kami disebut tikar pasir. Tebal dan lunak, member rasa santai bagi yang duduk di atasnya. Pasangan meja kursi rotan diletakkan di dekat pintu masuk. Vernisnya harus diperbaharui. Suamiku juga harus membuat rak buku. Hal tersebut akan dikerjakan setelah mengambil cuti waktu lebaran kelak.

Hari itu kami naik becak ke sekolah. Bersama anak sulungku, kami berlomba mencari pohon mangga yang tumbuh di sepanjang jalan. Halaman rumah kota besar jarang ditanami buah-buahan. Barangkali karena kami tinggal jauh dari pusat, kami masih menemukan lebih dari lima pohon. Kemudian kami menerka jenis pohon mangga apa. Warna bunganya pun berlainan. Ada yang kuning jernih. Ada yang agak kemerah-merahan atau coklat muda. Anakku 
membandingkan tempat tinggal kami yang sekarang dengan Purwodadi.

Setelah melewati pasar, jalan menuju ke sekolah menurun. Di situ kelihatan bagian kota yang paling baru. Kebanyakan gedung bergaya sesudah perang. Sehingga banyak sekolah menonjol kekunoannya. Nampak anggun meskipun warnanya sudah lusuh, terlalu lama tidak dicat. Sebelum becak berhenti di depannya, aku berkata kepada anak sulungku : "lihat di Purwodadi tidak ada sekolah sebagus ini". "Apanya yang bagus?" suara anakku kedengaran lugu. "Perhatikan baik-baik. Atapnya lain dari atap di sana itu. Gedungnya demikian pula. Bentuk tiang dan pintunya. Tidakkah kamu menyukainya? Di zaman sekarang tidak banyak gedung seperti ini."

Untuk mengatasi masalah murid yang bernama Waskito, aku mengirim surat kepada nenek Waskito. Pada suatu sore yang telah ditentukan, aku berkunjung ke rumah kakek dan nenek tersebut. Kini setelah duduk, baru beberapa menit berkenalan dan melihat keterbukaan hari wanita itu, aku merasa kerasan. Kami berada di rumah bagian belakang. Teras itu kelihatan ditambahkan setelah rumah selesai dibangun. Sekelilingnya dibatasi oleh dinding setinggi lutut, penuh pot tanaman. Seluruh kebun tidak begitu luas. Dari kursiku, aku dapat memandang sebagian daripadanya. Jauh di sudut, Nampak pohon pisang menggerombol menabiri tempat jemuran. Di dekatnya, anyaman bambu menyangga jaluran tanaman pare. Buahnya begantungan hijau muda menyedapkan mata. Di pinggir ada pohon papaya, dua berjejeran. Agak ketengah, pohon jambu air. Buahnya masih muda membentuk kelompokkelompok bagaikan lampu tertempel rapi di dahan dan ranting. Sebentar lagi mereka akan menjadi merah kesumba menggiurkan. Semuanya sederhana di sana. Tetapi kesan kekeluargaan juga besar.

Letak kampung kami bersambungan dan berdampingan dengan kampungkampung lain. Untuk menuju ke jalan besar, kami harus melewati satu atau dua kelompok pemukiman tersebut. Menurut berita, Waskito mempunyai sebuah kamar yang kelihatannya rapi terpelihara. Alat-alat pertukangan terkumpul di suatu lemari kecil lengkap dengan mejanya. Selesai digunakan, Waskito segera mengembalikan ke tempat semula.

Di dalam kamar itu juga bergantungan model-model pesawat. Pesawat-pesawat itu dibuatnya menuruti gambar di buku.

\section{Deskripsi latar sosial Novel Pertemuan Dua Hati.}

Ketika aku lulus SD, orang tuaku menasehatkan agar masuk ke sekolah guru. Untuk membujukku ibuku menambahkan bahwa libur guru sama panjangnya dengan anak sekolah. Melebihi orang yang bekerja di kantor.

$\mathrm{Aku}$ bercita-cita menjadi seorang sekretaris. Aku sering melihat gadis atau wanita muda yang mengetik dan mengurus kantor. Mereka selalu berpakaian bagus. Tata rambut maupun dandanan baju senantiasa rapi. Mereka kelihatan lebih cantik dan menarik daripada guru yang mengajarku. Waktu itu umurku masih sangat muda. Yang kuketahui, pekerjaan sekretaris hanyalah sebagai juru tulis. Keberesan kantor kukira sama dengan keberesan rumah tangga yang kusaksikan sehari-hari. Setelah dewasa, barulah aku mengetahui betapa rumit dan sukar menjadi sekretaris.

Aku anak yang patuh. Aku diantarkan bapak mendaftarkan diri di SPG Semarang. Kebahagiaan yang kurasa karena baru pertama keluar dari rumah. Tambah lagi, saat pulang berlibur bertemu orang tua dan tempat kelahiran.

Lulus SPG aku ingin melanjutkan ke IKIP. Meskipun kemampuan otak memadai bapak tidak sanggup membiayai. Adikku ada tiga orang, sehingga mencari nafkah ketimbang mengikuti program ikatan dinas lebih diharapkan.

Aku dididik orang tua agar hidup sebisa mungkin. Segala perselisihan 
pendapat diselesaikan dengan terbuka dan terus terang. Tetapi dalam kenyataan hidup sehari-hari aku lebih sering mengalah.

Agar biaya hidup tidak terlalu menekan bahu suamiku, aku harus kembali mengajar secepat mungkin. Menurut pendapatku, justru pada tingkat sekolah dasar sebaiknya anak- anak menerima pendidikan sepatutnya.

Sebagai orang baru dan untuk memenuhi tata cara aku memperkenlkan diri ke Rukun Tetangga. Aku bertemu dengan isteri RT, sebab suaminya sedang mengurus keperluan lain. Ramah dan sopan dia menyambutku. Dia menjadi anggota perkumpulan cukup banyak sehingga mengenal banyak orang.

Setelah menyelesaikan masalah lingkungan, aku berhadapan dengan tugasku. Kepala sekolah usul agar aku masuk dan mengajar dua kelas. Bagaimanapun besarnya cintaku kepada pekerjaan sebagai guru. Tanpa menunggu habisnya bulan itu, aku mulai mengajar.

Belum lama mengajar, anakku yang kecil sakit. Pendapat tetangga kemudian ditanggapi oleh uwakku bahwa anakku tidak cocok dengan "penjaga" rumah kami. Dan cara berpikir uwak hampir berhasil menjalari suamiku dan aku ketika beberapa hari mulai mengajar anakku tiba-tiba diserang panas atau demam keras. Suamiku tidak di rumah. Dengan menyewa Daihatsu anakku dibawa ke dokter. Setelah diperiksa dokter, namun tidak dijelaskan mengapa anakku sampai kejang-kejang.

Anakku yang kedua terus minum obat dan tidak mau tinggal di rumah. Akhirnya dia masuk sekolah dengan diantar. Kami bertiga naik becak dengan sulungku. Diperjalanan terjadi perbincangan antara aku dan anakku. "Di Purwodadi, Bapak tidak pernah pulang terlambat," tanpa kuduga, anak sulungku menambahkan.

Aku agak terkejut. Mungkin telah lama ditahannya. $\mathrm{Ku}$ coba menjelaskan letak kantor bapaknya yang jauh dari Purwodadi.
Selain masalah anak aku juga menghadapi masalah murid karena tugasku sebagai pendidik. Hari keempat masuk sekolah, aku mencari tahu tentang Waskito. Seisi kelas seperti bisu. Akhirnya diketahui dari penjelasan teman-teman Waskito bahwa dia sering memukul teman sekelas. Temannya berkata dulu Waskito tinggal bersama neneknya. Kemudian diambil oleh orang tuanya. Dari keterangan murid-murid kesimpulan yang dapat diambil sementara bahwa Waskito tidak berpura-pura dan ada kesulitan yang menggugah perasaanku untuk mengetahui lebih lanjut.

Persoalan murid tidak kubawa ke rumah. Rumah tempat keluarga dan bukan untuk mengeruhkan suasana dengan masalah dari luar rumah.

Aku mengirim surat kepada neneknya dan ditanggapi. Pada hari yang ditentukan aku mengunjungi nenek Waskito. Dari keterangan neneknya bahwa setelah orang tuanya tahu tentang keadaan Waskito belakangan sehingga dihajar habis-habisan.

Setengah tahun dititipkan dengan neneknya, rapor Waskito menunjukkan kemajuan. Namun sepertinya Waskito tidak pernah mendapat kesempatan untuk berpendapat seperti menentukan pilihan dia harus bersama siapa. Dapatkah aku menolongnya keluar dari persoalannya?

Sampai di rumah aku melupakan persoalan murid termasuk Waskito. Kami prihatin melihat anak kedua yang mengidap elektroensefalografik yang biasa disebut EEG. Berdasarkan kepercayaan kepada para ahli, kami berhasil menemukan kembali sedikit rasa ketenteraman. Yang disebut pasrah dalam filsafat Jawa juga sangat membantu. Dua hari terakhir, aku berturutturut ke dokter perusahaan dan rumah sakit. Untuk sementara selesailah pemeriksaan anakku. Tinggal berobat jalan atau mengambil obat jika habis.

Kemudian aku kembali mengajar. Beberapa saat aku berada di kantor. Tibatiba kulihat Waskito masuk, menuju ke tempatku. Tanpa berkata sesuatupun, dia 
meletakkan timbunan buku tugas di depanku.

$\mathrm{Aku}$ terpesona. Heran bercampur bingung, masih bisa mengucapkan: "terima kasih. Nanti akan saya periksa." Hari-hari selanjutnya menyusul kejadian-kejadian lain. Waskito masih sering mengganggu temannya. Namun dalam banyak hal Waskito mengubah sikap menjadi lebih patuh. Aku terus menerus mengamati perkembangan kelas. Sebulan berlangsung aku dapat tabah mengalami loncatanloncatan kebiasaan Waskito.

Hatiku mulai agak tenang. Meskipun ketenangan itu kesiagaan untuk menghadapi kejutan. Baik itu dari pihak murid sukarku maupun anakku.

Karena bukan hanya Waskito yang tertarik tentang pabrik rakyat maka aku merencanakan menunjukkan teori bejana berhubungan di kelasku. Murid-murid diberi tugas. Hari pengumpulan tiba, masingmasing regu membawa hasil kerja mereka. Ternyata pekerjaan regu Waskito yang paling baik dan rapi. Keterangan regunya mengatakan bahwa yang mampu mengerjakan hanya Waskito karena memiliki peralatan sendiri. Kejadian ini membesarkan hatiku.

Hampir tiga bulan aku bekerja, keadaan dapat dikatakan dapat dikatakan tenang. Tiba-tiba keadaan berubah. Seorang muridku terengah-engah datang, langsung berseru : "Bu Suci. Waskito kambuh, Bu. Dia mengamuk. Dia mau membakar kelas". Semua bergerak menuju kelas. Waskito memegang gunting. Aku merampas guntingnya dan diberikan kepada kepala sekolah.

Semua terjadi begitu cepat bagaikan kejapan mata. Dengan susah payah aku mempertahankan muridku. Guru-guru lain ingin mengeluarkannya. Aku memohon kepada kepala sekolah untuk diberi waktu. Walaupun usul tersebut ditanggapi dengan jengkel seorang guru. Aku meminta waktu satu bulan.
Aku kembali ke kelas setelah rapat. Kemudian aku mengganti tempat duduk murid kelasku. Kuberi pengertian tentang kedudukanku dan masalah anakku. Hingga waktu pulang, Waskito tetap duduk di tempatnya semula.

Malamnya aku gelisah. Tidurku sangat mengganggu. Keesokan harinya, ketika lonceng berbunyi aku masuk kelas. Waskito telah berpindah tempat, duduk tepat di depan meja guru. Hari itu berlalu dengan tenang. Aku bersyukur menyebut nama tuhan.

Waskito masih suka merusak tanaman temannya. Sehingga Waskito perlu diberi pengertian bahwa merusak tanaman juga telah membunuh. Waskito tidak masuk kelas. Akhirnya kutemukan Waskito di selokan. Dia mengatakan bahwa temannya mengejeknya. Akhirnya mau kembali ke kelas. Kejadian itu merupakan tambahan yang melengkapi pertemuan hari Waskito dan hatiku.

Akhir tahun pelajaran. Waskito naik kelas. Bu Denya datang ke sekolah. Dia berterima kasih kepada kepala sekolah, para guru, dan kepadaku. Aku menjawab bahwa aku gembira dapat menolong Waskito.

\section{Interpretasi latar fisik Novel Pertemuan Dua Hati}

Keterangan mengenai rumah

Keterangan mengenai rumah dalam novel PDH Karya Nh. Dini dimulai dengan, "rumah yang dikontrak suamiku besar". Selanjutnya dijelaskan bahwa kamarnya hanya dua, ruang tengah memanjang, ada kamar mandi, sumur dan kamar kecil di dalamnya.

Rumah tersebut cukup ideal untuk jumlah keluarga lima orang. Gambaran kongkret mengenai rumah dan isinya yakni setelah dua bulan tinggal di rumah baru.

Kami mulai mapan. Barang-barang sudah menemukan tempatnya masing-masing. Ruang tengah yang memanjang kujadikan ruang keluarga. Di pojok kuletakkan televisi. Di dekat dinding yang bertentangan, ada seperangkat meja-kursi 
untuk makan. Itu juga kami pergunakan sebagai tempat menggarap pekerjaan rumah, menulis atau menjahit. Di depan televisi kugelar tikar pandan anyaman dua permukaan yang di daerah kami disebut tikar pasir. Tebal dan lunak, member rasa santai bagi yang duduk di atasnya. Pasangan meja-kursi rotan diletakkan di dekat pintu masuk (Dini, 1992:17-18)

Ternyata kehidupan tokoh mulai mapan. Semua perlengkapan rumah cukup bahkan ada televisi. Walaupun tidak dijelaskan TV warna atau hitam putih.

Rumah RT juga mentereng dan berhalaman luas. Ternyata cukup banyak rumah bagus. Sehingga melihat rumah RT dan sekitarnya menimbulkan kesan mewah dan modern. Jika dibandingkan tempat tinggal mereka dulu di Purwodadi yang setengah batu dan setengah kayu tentu jauh berbeda. Keterangan rumah tersebut memberikan kesimpulan bahwa disekitar tempat tinggal sang tokoh kehidupan tetangga-tetangganya cukup mewah dan modern.

Teras bagian belakang rumah kakek dan nenek Waskito dibatasi oleh dinding setinggi lutut, penuh pot tanaman. Ada kebun pisang, kebun pare, pohon-pohon pepaya, dan pohon jambu air. Semuanya menimbulkan kesan sederhana. Kakek Waskito yang masih praktik di rumah sakit masih sempat berkebun. Walaupun tidak dijelaskan dikerjakan oleh tukang kebun atau memang kakek Waskito.

Sebetulnya Waskito adalah anak yang cukup terampil walaupun sebetulnya digambarkan sebagai anak yang sukar di sekolah. Kamarnya rapi dan terpelihara. Bagian ini juga belum dijelaskan tentang orang yang merapikan kamar Waskito atau memang Waskito rajin merapikan kamarnya. Keterangan yang memaparkan bahwa Waskito mampu membuat model-model pesawat yang dicontohnya dari gambar. Alat-alat pertukangannya terkumpul dalam lemari kecil lengkap denan mejanya. Jika dia menggunakan alat-alat pertukangannya setelah selesai tidak dibiarkan berantakan, tetapi segera dikembalikan ke dalam kotaknya.

Waskito selain terampil juga sayang terhadap alat-alat pertukangannya. Penggambaran atau keterangan mengenai rumah cukup memadai sehingga dapat ditelaah tentang kondisi rumah dalam cerita novel Pertemuan Dua Hati.

\section{Keterangan mengenai daerah}

Keterangan mengenai daerah dalam novel PDH sebagai berikut:

Purwodadi adalah tempat kelahiran $\mathrm{Bu}$ Suci sang tokoh. Purwodadi kota kecil, gersang, tanpa daya tarik (Dini, 1992:9).

Kota kecil tersebut tetap dikenang sang tokoh sebagai kota kelahirannya. Penilaiannya bahwa kota tersebut gersang dan tanpa daya tarik.

Daerah yang sering disebut tempat kehidupan sang tokoh adalah Semarang. Kota pelabuhan yang merupakan pintu gerbang berbagai pengaruh. Rumah-rumah berdekatan. Bagian-bagian tertentu kota ini bercampur dengan kebiasaan baru.

Kepadatan penduduk dikuasai pengaruh golongan Tionghoa (Dini, 1992:10).

Kota ini terbagi dua, yakni kota atas yang dinamakan kota Candi, dan kota Bawah yang ditempuh dengan naik "Daihatsu". Orang disana tidak berkata naik mobil atau naik oplet. Hal tersebut disebabkan merek mobil angkutan umum adalah Daihatsu.

Bagian kota yang paling baru yakni setelah melewati pasar menuju sekolah. Banyak gedung bergaya sesudah perang. Hal yang menonjol adalah kekunoannya. Meskipun catnya sudah lusuh namun terlihat anggun.

Keterangan tersebut di atas rasanya cukup untuk dikhayalkan oleh pembaca. Begitu juga tentang atap sekolah yang lain. Atap tersebut tidak dijelaskan lainnya seperti genteng atau seng. Namun pembaca 
mencoba menangkap sebagai bangunan atap yang kuno.

Letak kampung kami bersambungan dan berdampingan dengan kampungkampung lain. Untuk menuju ke jalan besar, kami harus melewati satu atau dua kelompok pemukiman tersebut (Dini, 1992:62).

Keterangan mengenai kampung mudah dipahami karena setiap desa biasanya berdekatan. Begitu juga mengenai pemukiman penduduk, lebih sering berkelompok-kelompok.

Keterangan mengenai daerah juga bagus. Purwodadi kota kelahiran. Semarang tempat tinggal mereka juga tempat mencari nafkah. Juga tentang kota Semarang yang terbagi dua yaitu kota atas dan kota bawah dan kebiasaan penduduk.

\section{Interprestasi latar sosial Novel Pertemuan Dua Hati}

\section{Keadaan Ekonomi Masyarakat}

Kondisi ekonomi masyarakat di sekitar tempat tinggal tokoh yang baru sangat layak. Hal tersebut dapat dilihat dari gambaran rumah yang mentereng. Rumah RT ternyata bukan satu-satunya rumah mewah. Artinya hamper semua rumah kondisinya mewah dan penghuninya memiliki taraf ekonomi yang lebih dari cukup. Rumah sang tokoh walau cuma dua kamar, tetap terlihat agak besar. Untuk menanggulangi perekonomian keluarga sang tokoh yang kedudukannya sebagai isteri juga turut mencari nafkah. Sehingga dalam dua bulan tinggal di Semarang, kehidupannya mulai mapan.

Kami mulai mapan(Dini, 1992: 17). Aku memilih menjadi pendidik, bagi anakanakku dan murid yang dipasrahkan kepadaku. Gaji atau penghargaan seringkali meleset, tidak sesuai dengan jasa yang secara rendah hati kami sumbangkan bagi pembangunan watak tiang masa depan bangsa. (Dini, 1992:85)
Walaupun gaji guru sering terlambat tetapi sang tokoh adalah orang yang percaya pada tuhan. Sehingga walau hanya sebagai guru, sang tokoh telah ikut menopang perekonomian keluarga sampai mapan. Keadaan ekonomi digambarkan sangat makmur. Jadi ekonomi tokoh cerita dari sangat sederhana menjadi mapan.

\section{Pandangan hidup}

Aku bercita-cita menjadi sekretaris. (Dini, 1992:9).

Sewaktu sang tokoh berumur masih sangat muda, memiliki cita-cita menjadi seorang sekretaris. Mereka terlihat sangat cantik dari guru yang mengajarnya. Rambut dan dandanan baju sangat rapi.

Setelah dewasa, barulah aku mengetahui betapa rumitnya dan sukar menjadi sekretaris yang baik (Dini, 1992:9).

Pekerjaan guru bukan pilihan sang tokoh, tetapi pilihan orang tua.

$\mathrm{Aku}$ patuh, menuruti nasihat orang tua (Dini, 1992:10).

Sang tokoh anak yang patuh sehingga ketika orang tua mengantar ke Semarang masuk SPG, sang tokoh ternyata tidak menyesal. Ibunya berkata bahwa guru merupakan pekerjaan yang cocok untuk wanita. Libur guru sama panjangnya dengan anak sekolah, ibunya menambahkan.

Sang tokoh tidak mencampuradukkan masalah rumah dengan sekolah.

Persoalan murid sukar tidak pernah kubawa ke rumah (Dini, 1992:34).

Ternyata sang tokoh masih mampu memisahkan masalah pekerjaan dengan masalah rumah. Masalah rumah ialah anak kedua sakit parah. Persoalan pekerjaan adalah tentang Waskito, murid sukar. Ketika kedua masalah tersebut memuncak, pandangan tersebut menjadi kabur. 
Aku tidak dapat lagi mempertahankan kebiasaan lamaku memisahkan keluraga dari sekolah (Dini, 1992:74).

Sebagai manusia biasa pandangan mengenai kehidupan luar jangan digabungkan dengan kehidupan rumah tangga tidak selamanya dipertahankan.

Ada pernyataan akhir bahwa pekerjaan sebagai guru sebenarnya sesuai dengan hati nurani sang tokoh.

Aku memilih menjadi pendidik, bagi anak-anakku dan murid yang dipasrahkan kepadaku (Dini, 1992:85).

Kalimat tersebut mengisyaratkan bahwa menjadi guru atau pendidik merupakan suatu pengabdian tulus bagi anak-anak bangsa. Artinya sang tokoh memiliki pandangan bahwa sebagai guru merupakan pekerjaan yang mulia.

Pandangan hidup sang tokoh cukup jelas yakni bercita-cita menjadi sekretaris. Menjadi guru pada akhirnya ditekuni karena memang pantas untuk wanita. Begitu juga pandangan sang tokoh yang tidak ingin mencampuradukkan masalah pribadi atau di rumah dengan pekerjaan di sekolah.

\section{Sikap hidup}

Sang tokoh adalah wanita yang patuh terhadap orang tua. Juga seorang yang menjalankan ibadah sesuai dengan keyakinannya. Bu Suci adalah seorang guru yang sangat perhatian terhadap muridmuridnya. Juga sebagai ibu yang bertanggungjawab terhadap keluarganya.

Menghadapi kenyataan bahwa muridnya mengalami kesulitan, ia berusaha sebisa mungkin untuk mendidik dan meluruskan murid-muridnya. Dia tampil membawa anak-anaknya ke dokter ketika suaminya tidak di rumah. Dia juga ikut bekerja agar kehidupan mereka menjadi mapan.

Dia adalah wanita yang sabar menghadapi masalah. Ketika murid sukarnya membuat masalah lagi, dia masih memohon meminta waktu memperbaiki murid sukarnya. Dia tidak peduli dengan cemoohan rekan gurunya. Kembali ke rumah dia berupaya mengobati anaknya yang sakit keras.

Sang tokoh merupakan tokoh yang selalu ingin tahu. Dalam arti sangat bertanggungjawab mencari keterangan mengenai murid sukarnya. Guru-guru tidak peduli dengan masalah Waskito, dia tidak peduli.

$\mathrm{Bu}$ Suci adalah tokoh yang terpesona. Melihat murid sukarnya mengalami perubahan yakni mau membawa dan meletakkan buku-buku di atas meja, dia terpesona. Jauh di dalam hatinya berharap bahwa murid sukarnya mengalami perubahan yang lebih berarti atau menjadi normal. gelisah.

Sang tokoh juga seorang tokoh

Tidurku sangat terganggu (Dini, 1992:71).

Dia sangat memperhatikan dan merasa paling bertanggungjawab terhadap sikap murid sukarnya.

Dia juga seorang tokoh yang tenang. Sikap hidupnya sangat wajar, berusaha selalu tenang. Meskipun tetap dalam kesiagaan untuk berhadapan dengan sesuatu kejutan.

Dalam menghadapi Waskito, sang tokoh menganggapnya sebagai anak remaja.

Berhadapan dengan dia aku memutuskan mengambil sikap seolah-olah berhadapan dengan remaja betul-betul (Dini, 1992:56.)

$\mathrm{Bu}$ Suci adalah sosok guru ideal. Seorang wanita yang bertanggung jawab. Selain itu juga seorang yang bijaksana dalam menghadapi setiap persoalan yang dihadapi.

Sikap hidup sang tokoh yakni menjalankan ibadah, bertanggung-jawab terhadap masalah di rumah dan pekerjaan, mudah terpesona. Walaupun gelisah juga 
berupaya untuk tetap tenang. Singkatnya sikap hidup sang tokoh telah digambarkan dengan cermat.

\section{PENUTUP}

\section{Simpulan}

Berdasarkan hasil analisis atau kajian terhadap latar fisik dan latar sosial Novel Pertemuan Dua Hati Karya Nh. Dini dapat disimpulkan bahwa latar fisik yang disajikan meliputi keterangan mengenai rumah dan tempat tinggal sang tokoh telah dipaparkan dengan kongkret. Selanjutnya keterangan mengenai daerah juga disajikan dengan jelas dan nyata. Sedangkan latar sosial yang digambarkan meliputi keadaan ekonomi masyarakat sekitar tokoh sangat layak dan mewah, sedangkan perekonomian sang tokoh pas-pasan sehingga sebagai seorang istri turut mencari nafkah sebagai seorang guru. Pandangan hidup atau cita-cita tokoh yang ingin menjadi sekretaris akhirnya pupus karena pilihan orang tuanya untuk menjadikan dirinya sebagai seorang guru. Sikap sang tokoh yakni patuh terhadap orang tua, taat beribadah menjalankan perintahNya, bertanggung jawab terhadap masalah anak di rumah dan anak didik di sekolah.

\section{Saran}

Mengingat masalah penelitian hanya terbatas tentang latar, sebaiknya untuk penelitian berikutnya ada peneliti yang melanjutkan penelitian ini dari aspek yang lain. Penelitian ini dapat menunjang penelitian sastra lain terutama novel.

\section{DAFTAR PUSTAKA}

Aeini, Sri Nur. 1995. Aspek Penokohan Novel Para Priyayi karya Umar Kayam. Pontianak: FKIP Untan.

Dini, Nh. 1992. Pertemuan Dua Hati.Jakarta : PT Gramedia Pustaka Utama.

Effendy, Chairil. 1985. Novel dan Puisi Karya Kontowijoyo sebuah pembicaraan. Pontianak : FKIP Untan.

Fuadi, Deti Syamrotul Fuadi. 2016. Intisari dan Bank Soal Penunjang Pelajaran Bahasa Indonesia.Bandung : Yrama Widya.

Priyadi, Anton Totok. 1994. Tinjauan Sosiologis Sastra terhadap kumpulan cerpen senyum karyamin karya Ahmad Tohari.Malang : IKIP Malang.

Semi, M. Atar. 1993. Metode Penelitian Sastra. Jakarta: Gramedia Pustaka Utama.

Sentosa, Wijaya Heru dan Wahyuningtyas, Sri. 2010. Pengantar Apresiasi Prosa. Surakarta : Yuma Pustaka.

Siswandarti. 2009. Panduan Belajar Bahasa Indonesia untuk SMA Kelas XI. Yogyakarta : Dinas Pendidikan Menengah dan Non Formal Kabupaten Bantul.

Sudjiman, Panuti. 1991. Memahami cerita rekaan. Jakarta : Pustaka Jakarta.

Sumardjo dan Saini, K.M. 1986. Antologi Apresiasi Kesusastraan. Jakarta : Gramedia

Sumardjo dan Saini, K.M. 1991. Apresiasi Kesusasteraan. Jakarta : Gramedia Pustaka Utama

Suroto. 1990. Teori dan Bimbingan: Apresiasi Sastra Indonesia. Jakarta: Erlangga.

Tarigan, Henry Guntur. 1984. Prinsipprinsip dasar sastra.Bandung : Angkasa 
Volume $6 \quad$ Nomor 1, Juni 2018

Halaman $81-95$

\title{
STRATEGI RESPONS PUJIAN YANG DIGUNAKAN ORANG AMERIKA DAN ORANG BUGIS \\ (Strategies Used by Americans and Buginese in a Complimentary Respondent)
}

\author{
Mutmainnah Hasyari \\ Universitas Hasanuddin Makassar \\ Jl. Perintis Kemerdekaan Km. 10, Tamalanrea, Kota Makassar, Sulawesi Selatan \\ Pos-el: mutmainnah.hassyari1990@gmail.com
}

(Diterima: 20 April 2018; Direvisi: 13 Mei 2018; Disetujui: 3 Juni 2018)

\begin{abstract}
Americans and Buginese have the strategies to respond the compliment which are different from the theory that proposed by linguists. The aims of this research were (1) addressing types of strategies used by the Americans and Buginese to respond the compliments based on gender; and (2) disclosing the effect of complimentary responses in American and Buginese culture. The research data consist of English and Buginese language. Data on English language were taken from the you tube that contained the strategies used by Americans to respond the compliment, while Buginese data were gathered from the field by recording DCT questionnaire. Both types of data were analyzed by using descriptive qualitative. The result of research showed that (1) complimentary responded strategies used by American and Buginese were applying the complimentary responded category of Holmes (1988, 1993). Other wise, the types of the complimetary respond that used by Buginese, such as joke and social norm did not appeart in this theory. Both American males and females tended to respond the compliments by acceptance, while females Buginese tended to accept the compliments by showing solidarity between interlocutor and reject the compliment to avoid self-praise. Males Buginese tended to accept jokes not compliments in. (2) the exsistance of Culture played important roles to respond the compliments to nor the Americans orBuginese. The Americans responded the compliments with simple answers and accepted them as the princip of informality and equality. Buginese prefered to respond the compliments with other compliment or inferiority because they were leaning on the principle known as 'sipakatau', sipakalebbi', and 'sipakainge'.
\end{abstract}

Keywords: compliments, strategies, gender, culture

\begin{abstract}
Abstrak
Dalam merespons pujian, orang Amerika dan orang Bugis memiliki strategi yang berbeda dengan teori yang telah diusulkan para ahli. Penelitian ini bertujuan (1) menunjukkan jenis strategi yang digunakan oleh orang Amerika dan orang Bugis dalam merespons pujian berdasarkan jenis kelamin dan (2) mengungkapkan pengaruh budaya orang Amerika dan orang Bugis ketika merespons pujian. Data penelitian terdiri atas bahasa Inggris dan bahasa Bugis. Data bahasa Inggris diambil dari video youtube yang mengandung kalimat respons pujian oleh orang Amerika. Sementara data bahasa Bugis diambil dari lapangan melalui proses rekaman dan kuesioner DCT. Kedua data dianalisis menggunakan metode deskriptif kualitatif. Hasil dari penelitian ini menunjukkan bahwa (1) respons pujian oleh orang Amerika dan orang Bugis masih mengaplikasikan kategori respons pujian dari Holmes (1988, 1993) Namun, di sisi lain terdapat tipe respons pujian bahasa Bugis yang tidak dijelaskan dalam teori, yaitu tipe bergurau dan norma sosial. Baik laki-laki maupun perempuan Amerika lebih cenderung merespons pujian dengan tipe menerima, sedangkan perempuan Bugis lebih cenderung menerima untuk menunjukan solidaritas terhadap mitra tutur dan menolak pujian untuk menghindari sikap meninggikan diri. Sementara laki- laki Bugis cenderung bergurau daripada menerima pujian. Laki- laki Bugis juga cenderung menolak pujian. (2) Kehadiran budaya sangat berpengaruh dalam merespons pujian, baik oleh orang Amerika maupun orang Bugis. Orang Amerika merepons pujian dengan jawaban sederhana dan cenderung menerima pujian karena mereka berpegang pada prinsip informal dan kesetaraan, tetapi orang Bugis cenderung merespons pujian dengan kembali memuji atau dengan merendah diri karena mereka bersandar pada prinsip yang mereka sebut sipakatau, sipakalebbi,dan sipakainge.
\end{abstract}

Kata-kata kunci : pujian, strategi, jenis kelamin, budaya

\section{INTRODUCTION}

The term of a speech act is defined as an utterance as a functional unit in communication. According to Ziaei (2012), a speech act has two kinds of meaning: proposition or locution meaning 
and illocutionary meaning. For example, "The phone is ringing," the propositional meaning is what it says about the ringing of a telephone. The illocutionary meaning is what the speaker intends, for example, a request to answer the telephone. Furthermore, someone performs speech acts in offering an apology, greeting, request, complaint, invitation, compliment, or refusal. A speech act is also showed in utterance as in "Hey, I really like your tie!" to serve compliment or in sentence "you are very kind" to present a praise to someone. Speech acts include real- life interactions and require not only knowledge of the language but also appropriate use of that language within a given culture.

Compliment is one of the utterances that people often use in conversation through language. As mentioned earlier, compliment is one of speech acts which serve expression or positive evaluation that commonly occurs in everyday conversation encounters among the interlocutors. Holmes in $\mathrm{Wu}$ (2008), defined "A compliment is a speech act which explicitly or implicitly attributes credit to somebody other than the speaker, usually the person addressed, for some good (possession, characteristic, skill, etc.) which is positively valued by the speaker and the hearer". Compliment is often found in daily conversation within people in the society. A compliment may be used to open a conversation or to smooth conversational interaction by building up the links of solidarity among the interlocutors and as well as a compliments used to create a good social relationship. Someone used a compliment which relates to personal, appearance (e.g., clothes, hair), possessions, skill, or accomplishments. Knapp et al in Shahsavariaet al (2014), defined that Compliment responses mainly give back the social-cultural standards and varieties of certain speech communities.

Some previous researches were conducted related to issue of compliment response in some countries. The strategies of compliment response and some particular factors affecting compliment response such as age, gender, education, etc become the crucial issues in conducting research on compliment response. Lorenzo- Duzin Ebadi\& Salman (2015), examined a corpus consisting of a thousand compliment responses by British and Spanish male and female undergraduates. The results showed the existence of cross- cultural and crossgender similarities as well as difference among four groups of subject. For example, Spanish makes tended to upgrade compliments ironically (a type of compliment response absent in the British data) more frequently than their female counterparts.

Katsuta (2012), did research on compliment responses related to topic of compliment. His research investigated the role of compliment topic by analyzing compliment responses between Japanese and American college students. The result denoted that compliment responses can be seen as solutions for maintaining a balance between (1) a preference to avoid selfpraise and (2) a preference to accept or agree with the compliment. Building on studies showed that response strategies can be influenced by compliment content and context, the study analyzed responses to compliments on ability, achievement, belongings, appearance, and personal characteristic by determining the subject's choices of response strategy categorized as acceptance, avoidance, or rejection for each compliment topic.

$$
\text { Ibrahim \&Riyanto (2011), }
$$
compared the compliment response between American and Indonesian. Their research resulted that both of American and Indonesian have different and similar way of expressing responses to compliment. The difference might be due to the different cultural background. Although there were some similarities, the frequencies of each type could give a clear insight on the role of those different 
cultural backgrounds. Both the American and Indonesian respondents used ten types of compliment responses, eight of them were based on Herbert's categories, the others were the Indonesian respondent only. The eight types were Appreciation Token, Comment Acceptance, Praise Upgrade, Reassignment, Return, Scale down, and No Acknowledgment. The other two were promise and hope. Furthermore, the research found that the status became an important variable in giving response to compliments. Appreciation Token were used more by the Indonesian and American subordinates than by their superiors. On the other hand, Comment Acceptance were used more often by both the Indonesian and American superior.

Al- Falasi (2007) compared Arabic learners of English with English native speaker. His result showed that there was no difference culture in the use of compliment. The difference happened when it came to compliment responses. For instance, according to Ghawi (1993), in Arabic South Africa, English speakers more frequently accepted the compliment rather than rejected it. On the other hand, Asian non-native speakers of English prefered to reject the compliment, as they difficulted in responding appropriately the compliments.

Chen (1993), compared the compliment responses produced between American and Chinese. In his investigation, He used DCT (Discourse Completion Test) questionnaire to the respondents of his research to gain the objective of his investigation. His result found that Chinese used rejection, higher than the Americans. It is about 95.73\%.. On the other hand, the category of acceptance was only $4.4 \%$..

Based on that topic above, this research aimed to show various strategies of compliment response used by American and Buginese based on gender. Likewise, this research alsaimed to reveal the underlying culture's background related to varied topic of compliment.

\section{LITERATURE REVIEW}

This chapter deals with three parts. First, it concerns with brief reviews of some related studies previously conducted on compliment response. Second, it relates on the underlying concept that frames as well as some related ideas in this study. Third, it presents the theoretical framework which shows how the underlying concept in this study is related to the questions investigated in this research.

\section{A. PREVIOUS STUDIES}

A number of investigations as inspired by Herbert's extensive research on compliment response had been conducted comparing compliment responses. Daikuhara (1986), had collected 115 compliments of natural conversations by 50 native speakers of Japanese. His investigation found that Japanese doing compliment seem to serve the addresser's compliance to the recipients and this may madedistance between both interlocutors. In order to maintain harmony between them, the recipients tend to reject or deflect the compliment.

Chen (1993), compared the compliment responses produced between American and Chinese. In his investigation, He used DCT (Discourse Completion Test) questionnaire to the respondents of his research to gain the objective of his investigation. He found that Chinese used rejection higher than the Americans. It is about $95.73 \%$. On the other hand, the category of acceptance was only $4.4 \%$ from the compliment responses.

Later on, Gajaseni (1994), had compared the compliment responses produced by American and Thais. He used Discourse Completion Test (DCT), the same methodology which was used by Chen (1993). He conducted an analysis of 
different compliment response types which consist of acceptance, rejection, and indirection. The result of his study denoted that the Americans used acceptance type responses significantly more frequent than the Thais.

Nelson et al., (1996), had investigated compliment response concern to gender. They analyzed the similarities and differences of compliment responses between the Egyptians and the American by interview sessions. One of the purposes of the research was concerning the gender of the compliment giver and the recipients. His respondents were 20 American students and 20 Egyptian students; which all of them were men and women students. The result indicated that their patterns of compliments were similar primary adjectival and it was being the reason for the positive meaning. Besides that, the study furthermore showed that the Americans produced compliments more commonly as to the Egyptians.

The similar research also investigated by Ibrahim and Riyanto (2000). They compared compliment response between American and Indonesian. Their research resulted that both of American and Indonesian have different and similar way of expressing responses to compliment. The difference may be due to the different cultural background. Although there were some similarities, the frequencies of each type could give a clear insight on the role of those different cultural backgrounds. Both the American and Indonesian respondents used ten types of compliment responses, eight of which were based on Herbert's categories, the others were used by the Indonesian respondent only. The eight types were Appreciation Token, Comment Acceptance, Praise Upgrade, Reassignment, Return, Scale down, and No Acknowledgment. The other two were promise and hope. Furthermore, the research found that the status became an important variable in giving response to compliments. Appreciation Token was used more by the Indonesian and American subordinates than by their superiors. On the other hand, Comment Acceptance were used more often by both the Indonesian and American superior.

Lorenzo- Duz (2001), had examined a corpus consisting of a thousand compliment responses by British and Spanish male and female undergraduates. The results showed the existence of cross- cultural and crossgender similarities as well as difference among four groups of subject. For example, Spanish tended to upgrade compliments ironically (a type of compliment response absent in the British data) more frequently than their female counterparts (Ebadi and Salman, 2015).

Hiba Qusay Abdul Satar and Salasiah Che Lah (2009), had investigated a research concern to compliment responses in English among Iraqi Postgraduate at University Sains Malaysia (USM). He attempted to show whether the respondent will produce compliment response in the same time with pragmatic transfer process. Their research resulted that this certain group had adapted differences types of compliment responses. Definitely pragmatic transfer was existed in compliment responses produced by the respondent. Both researchers concluded this might happens due to the respondent's lack of knowledge of different sociolinguistic rules among cultures. Besides that, it could also because of the respondents' dependence on their mother tongue sociolinguistic norm in presenting speech act in the target language.

A research under the title "The Role of Compliment Topic and Compliment Response" was conducted by Katsuta (2012). His study investigated the role of compliment topic by analyzing compliment responses between Japanase and American college students. The result denoted that compliment responses can be seen as solutions for maintaining a balance between (1) a preference to avoid selfpraise and (2) a preference to accept or 
agree with the compliment. Building on studies showing that response strategies can be influenced by compliment content and context, the study analyzed responses to compliments on ability, achievement, belongings, appearance, and personal characteristic by determining the subject's choices of response strategy categorized as acceptance, avoidance, or rejection for each compliment topic.

It can be seen that the number of researches or investigations done on compliment and compliment responses. Though, none of them was associated and compared it with local language especially in Buginese language in Pinrang Regency and based on gender. Hence, this research attempts to study the comparison of the Buginese and Americans' responses to compliments. The researcher will focus on the strategies of compliment response from two groups in term of their gender. On top on that, this research will aim at inferring the respondent's perspective behind the culture's backgrounds of choosing certain types of compliment response by virtue of the topic compliment response.

\section{THEORETICAL BACKGROUND}

The term of speech community should be advanced. One of the researcher denoted that a speech community is a group of people who attribute a set of norms about the use of a language or languages (Gumperz in Chaika, 1994: 309). Meantime, Fishman (1972), assigned the definition of a speech community is all members or group of people who serve a single of variety and it'snorms appropriately. Summarily, it can be concluded that a speech community is a group of speakers which share a single speech variety and has the same rule for speaking. In addition, Labov's in Wardaugh, 1998 defined of speech is not symbolyzed by any agreement of language elements. Likewise the participation in a set of shared norms. These norms are recognized by the types of evaluative behavior and the uninformity of abstract patterns of variation respect to certain levels of usage. Basically, a speech community must at least share rules for speaking because members of a speech community may not use the rules of language in the same way.

Sociolinguistically, Language and human kind are related to each other. As one of important things in communication, language is used by society to interact with others. The study of relationship between language and society is called sociolinguistics. Several scholars describe sociolinguistics such as, Hymes (1974: vii) defined sociolinguistic connected between laguage and society with the aim to make a better understanding of the structure of language and the function of laguage and the function language in communication. Additionally, William Downes (1984: 15) defined sociolinguistics as the part of linguistic which studies about properties of language and languages which require reference to social, including contextual factors on their explanation. Summarily, sociolinguistics concerned with the use of language in relation to social dimension that involves the social relationships of social community. It means that sociolinguistics is connected with the way people use language when they interact each other so that it can be seen what the language patterns are and how they are used in any situation of communication. Therefore, investigating the way people use language in different social contexts results a great of information about the way language applies, as well as relate to the social relationships in any community.

Thomas (1995: 22) had defined the term of pragmatics as meaning in interaction. He emphasized that meaning is not something which inherent in the words alone, nor is it produced by the speaker neither the hearer. It means that there is a changing process including the negotiation of meaning between speaker and hearer, the context of utterance (physical, social, 
or linguistic) and the meaning potential of one utterance. Furthermore, Yule (1996) defined that the term of pragmatics studied about contextual meaning. This type of study includes the interpretation of the way people mean in a certain context and how the context affects of what is said. It also needs a consideration with who they are talking to, where, and in what circumstances. Thus, the benefit of studying language in pragmatics are understanding people's intended meaning, their assumptions, their aims or goals, and kind of actions that they performwhen they speak to the interlocutor.

Basically, as Holmes (1992), said that language has two purposes; referential and affective. It denoted objective information of a referential kind and it can also express the feeling of someone. As an interlocutor, in conveying something on his or her mind, one has to make sure that the aim of the sentences that being used are relevant with interpretations and perceptions about the roles of the sentences themselves. This is one of the comprehensions that making appropriate compliment response from one person to another is important. Holmes (1992) denoted that social factors have an important role in the use of language in human interaction. For some reasons, emphasis will be given to the users of the language, while others will concern with its uses which are the social setting and function of interaction. In particular situations, the speakers and the recipients are important factors that need to be allowed for, whereas in other situations, the essential aspect is the setting or the social context. Additionally, the objective of the communication maybe important, while in other circumstances, the topic has a control over the choice of language being used in a conversation.

Wu in 2008, concluded six types of compliment based on its' function, they were; a) To show admiration or approval of someone's work/ appearance/ taste (Herbert, 1986).

Example: I like your hat

This kind of compliment only make a compliment to someone appearance and show the speaker's admiration.

b) To establishconfirm/maintain solidarity (Wolfson, 1989). When a stranger comes into a group and makes the utterance in example above, it also can be regarded as a method to establish a new friendly relationship in the group.

c) To replace greetings/gratitude/ apologies/congratulations

(Wolfson. 1983). When two friends meet with each other, one of them utters a sentence like;

Example: How are you today!

This utterance has the same function of the greeting as "How are you?"

d) To soften face threatening act such as apologies, requests and criticism (Wolfson, 1983), if the speaker makes some offence to the hearer. He can use a compliment to change the topic and soften the tense atmosphere.

e) To open and sustain conversation or conversation strategy (Wolfson. 1989). If the interlocutors are strangers, they can begin their conversation from the compliments to open the dialogues. It describes in example below;

Example :Hi, your English is very good, when did you begin to learn it?

f) To reinforce desired behavior (Manes, 1981). It is usual in daily life.

Example: "How nice your ear rings are!" "Where did you buy them?"

Investigation through the topic and structure of compliments has been done by 
Knapp et al., (1984). He denoted that most compliments are given to interlocutor or to the recipients of the same age and social status. On top of that, according to Herbert (1989), in American English, Agreement responses happen just about one third of the time and generally. Major compliment topics can be classified into three categories based on objet of compliments; appearance/pessesions,

performance/skill/abilities, and personality traits (Manes \&Wolfson, 1981, Knapp et al., 1984, Wolfson, 1989, Herbert, 1998).

Compliments in certain situations have different meanings and functions. Basically, they usually use as a politeness strategy to make other feel comfortable and maintain the conversation. Talking about the compliments in Asians countries, as stated by Kartomihardjo (1978), a speaker tend to be careful in performing compliments to someon. As Asian people, compliments are not quite general. According to his perspective, a close relationship between the speaker and the recipient is an important condition before compliment is expressed. The closer relationship both of them possess, the more openness they have in stating their compliments to one and another.

\section{Longman Dictionary of \\ Contemporary English (2004),}

Compliments are very important speech act and cooperative strategy in humans live. It has three kinds of meanings namely to express admiration of someone or something, to show that we trust someone else and have a good opinion of them, to express praise, or good wishes (Wu, 2008).

In the free dictionary (2008), compliments have the same meaning: they can be expressions of praise, admiration, or congratulation; they can be formal act of civility, courtesy, or respect; or they can be good wishes; regards ( $\mathrm{Wu}, 2008)$. Some researchers have made some definitions about compliments, Among the famous and standard one is Holmes' version:
A compliment is a speech act which explicitly or implicitly attributes credit to someone other than the speaker, usually the person addressed, for some 'good' (possession, characteristic, skill, etc) which is positively valued by the speaker and the hearer (1986: 485)

From the descriptions before, it is easy to see some principles that define compliments: it is a polite speech act, it can be direct or indirect, which means it can has an explicit form meaning that people can distinguish it quickly, or it can has not an obvious structure. However, people still regard it as a compliment, only if it can attribute credit to someone according to its implicit meaning, and the last, it is given to others, not to the speakers themselves.

Pomerantz (1978) was the first researcher who studied the compliment responses. In her research finding, she denoted that, in American English, the addressee of a compliment faces two (2) contradiction conditions which pose a tight spot when responding it; (A) Agree to the speaker, and (B) Avoid self- praise. For instance, the addressee agrees with| the addresser by accepting the compliment praise (condition A), it breaks condition B in that the response goes against the speaker's sociolinguistic expectations. However, when the addressee does not agree to the compliment in order to follow condition $\mathrm{B}$, the response can be considered as face- threatening since it breaks condition $\mathrm{A}$ the addressee of the compliment implements a variety of solutions to overcome this clash, categorized by Pomerantz as (1) Acceptance, (2) Rejection, (3) Self- praise Avoidance.

Leech (1983) showed his compliment response research by recognized model of politeness. He stated that one way for speakers to breach conversational principles is to be polite. Hence, he proposed six maxims to account for a variety of response compliments, such as accepting, returning, mitigating, 


\begin{tabular}{|c|c|c|}
\hline $\begin{array}{c}\text { Macro } \\
\text { level of } \\
\text { CRs }\end{array}$ & $\begin{array}{c}\text { Micro level of } \\
\text { CRs }\end{array}$ & Examples \\
\hline Accept & $\begin{array}{l}\text { - Appreciation } \\
\text { token } \\
\text { - Agreeing } \\
\text { utterance } \\
\text { - Downgrading } \\
\text { - Return } \\
\text { Compliment }\end{array}$ & 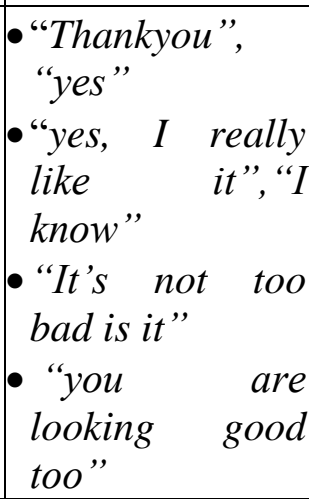 \\
\hline Reject & $\begin{array}{l}\text { - Disagreeing } \\
\text { utterance } \\
\text { - Question } \\
\text { accuracy } \\
\text { - Challenge } \\
\text { sincerity } \\
\end{array}$ & $\begin{array}{l}\text { - "No, it was } \\
\text { good" "Really?" } \\
\text { - "Don't lie" }\end{array}$ \\
\hline Avoid & $\begin{array}{l}\text { - Shift Credit } \\
\text { - Invormative } \\
\text { Comment } \\
\text { - Request } \\
\text { reassurance }\end{array}$ & $\begin{array}{lr}\text { - "My mother } \\
\text { "knitted it". } \\
\text { - "It was } & \text { not } \\
\text { hard" } & \\
\text { - "Dorrr you } & \text { really think } \\
\text { so?", } & \end{array}$ \\
\hline
\end{tabular}

and rejecting, by the application of one or more than one maxim. For instance, accepting compliment can be considered as adherence to agreement maxim; returning compliments can be seen as an application of the Agreement Maxim and the Approbation Maxim; offering object of compliment or help as application of the Agreement Maxim; deflecting a compromising strategy between the needs to sticks onto the agreement Maxim and the Modesty Maxim; and rejection as Adherence to the Modesty maxim.

Brown and Levinson (1987) also proposed model of politeness in western context, accepting compliment shows the addressee's face wants because the former anoints the face of the recipients to be approved and liked. Still, the model which proposed by them cannot clarify the implementation of other kinds of strategies, such as returning, or deflecting by English speakers (Holmes, 1988) or the primary use of the rejecting by the Mandarin interlocutors (Chen, 1993).

After analyzing American English speaker's compliment responses, Herbert (1986) reform Pomerantz's taxonomy. Within 3 years, he collected more than a thousand samples of compliment responses of the American college students.

Similar findings are provided by Holmes (1988). Holmes believes that "a compliment not only makes a positive assertion, it also attributes credit to the addressee in relation to that assertion" (492). Based on this assumption, she developed three categories of compliment responses.

Holmes' (1988, 1993) taxonomy of CR strategies

Humans can be categorized into male and female in terms of biological sex. It is looked from their sex organs and genes. Besides that, by using gender to divide humans, it can be adopted a psychological and cultural term which involves the subjective feelings of maleness and femaleness. Meanwhile, gender also refers to society's evaluation of behavior as masculine or feminine (Basow et al., 1992). There are differences between women's and men's voices that have been studied from some aspects. In terms of biological aspects, men and women have the different physical vocal tract, therefore, the voice of women is various from men. For example, on the pitch, women usually speak with a high pitch because women have short and thin vocal folds while men speak at a low pitch (Graddol\& Swann, 1989:15).

There are differences between women's and men's voices have been studied from some aspects. In terms of biological aspects, men and women have the different physical vocal tract, therefore, the voice of women is various from men. For example, on the pitch, women usually speak with a high pitch because women 
have short and thin vocal folds while men speak at a low pitch (Graddol\& Swann, 1989:15). Spender's view in terms of social aspect of voice, mentioned that there were differences between women and men. Men usually use lower pitched voice not only because the anatomy but also their will to use the low pitched voice (Graddol\& Swann: 1989:18). For men, using the high pitched voices will be regarded as ridicule which will destroy their images. The lower pitched voices are regarded as more confident and dominant than higher pitched ones in men's opinions. In society, men are usually the authoritative group. They are the center of the society and the dominance while women are usually the subordinate groups in the society. bSome differences between men and women in speech act have been found (Coupland, 2000);

a. Women are more socially
engaged cooperative and
constructive than men;
b. Women are more silent than men in public, so they are a muted group;

c. Women ask more questions than men in speech pattern;

d. Women are interrupted more than men;

e. Women have different choices and frequency of the lexical items from men;

f. Women use more politeness behaviors than men.

\section{METHODOLOGY}

\section{A. Research Design}

This research aimed to find out the strategy in responding the compliment in American and Buginese. The researcher used two sources of data which were American compliment responses that was found inyou tube video and Buginese compliment response carried out by speakers in the field of social situation and Discourse Completion Test (DCT). The writer applyedqualitative descriptive method. According to Sugiyono (2010), the purpose of the research wasobtaining an accurate profile of the people, events or situations. So it guided the researcher to explore the data in comprehensive, extensive and deep waysThrough this research, the writer finally analyzed the data andexplained explicitly the strategies of compliment response that used by American and Buginese based on gender.

\section{B. Source of Data}

There were two kinds of data in this research. The first data was American data. It was gained by the conversation of the Americans in video youtube.com. All videos related to the compliment responses which had been downloaded. The second data was Buginese data. It was gathered by using a Discourse Completion Test. DCT questionnaire according to Blum- Kulka in Duan (2011), is designed to get compliments response patterns of the participants in the questionnaire. It was carried on to draw out compliment responses based on the topic of compliment. Besides that, the Buginese data was also gained by recording. The researcher did recording earlier. The researcher was recorded the dialogue which contained of compliments response naturally. Therefore, in this research, the analyzed data were the data that was gained from a DCT of the questionnaire and observation.

\section{Procedures of Collecting Data}

In collecting data, first of all, in Buginese data, the researcher dealt out a questionnaire to the participants. In this step, the researcher applyed a DCT and recording to draw out data which was related to this research. Meanwhile, the American data was gained by downloaded all conversation videos dealt with compliment response in video youtube.com. Then it was transcribed. The topic of compliment should be equal in order to make iteasy to be analyzed and 
compared both of the data by the researcher.

\section{Technique of Analyzing Data}

In technique of analyzing data, the researcher used some techniques in order to answer the research questions in the first chapter. First, the collected data were categorized into three types based on Holmes in Sadeghi\&Zarei (2013), Compliment Responses; Accept, Reject and Avoid. Second, the identified data were compared to show the difference strategies between American and Buginese. Last, the culture that influences both of groups were identified related to the response when they pay a compliment.

\section{FINDINGS AND DISCUSSIONS}

According to this research, the result revealed that American in responding the compliment still applyed the type of compliment response proposed in the theory. However, on the other hand, there were two types of Buginese compliment response uncovered by theory. They were joke and social norm and theothersthatcharacterized as Accept (appreciation token, agreeing utterance, downgrading and returning compliment), avoid (shift credit, informative comment, request reassurance) and reject (disagreeing utterance, question accuracy, challenge sincerity) which have been covered by the theory.

This part presented the strategies of compliment response that used by the speakers of Americans and Buginese people. The findings of the research were presented in some of tables based on Holmes' classification in compliment response. Each of the table shows the response of speakers and classifies them based on the speaker's perspective (acceptance, avoidance or rejection)in obviously different topic (appearance, possessions, ability and personality traits).

The responses of compliment in this research were categorized based on
Holmes (1988, 1993) taxonomy. Chen (1993) noted that Holme's taxonomy reflected the insight Pomerantz's (1978) constraints: the need to agree with the complementer motivated the acceptance of a compliment, the need to avoid self-praise motivated the rejection of a compliment, and the need to strike a balance between the two constraints led to the utterances that mitigated the compliment by avoiding it.

The data presented the compliment responses by female and male Buginese speakers which were collected by Discourse Completion Test (DCT) questionnaire.There were some various data of compliment response that were obtained by the writer. The data were taken from Buginese society in Pinrang. There were various responses that found in the data. The first datum was the participant who were involving in the male's response to female complementer with possession topic of compliment such as, "de', anu masempo iye e (no, it's cheap)". The next datum was the same kind of participant but different topic. The topic was appearance topic of compliment. From the six participants, most of them avoid the compliment as well with the general response "malebbi pi pute ta' na iya' (You are brighter than me)". These responses showed that the participants tended to avoid the compliment in informative comment. It was based on Holmes' (1988, 1993) taxonomy of compliment response strategies in avoiding and its micro level was informative comment. In this datum, the participants was the male who gave response toward another male as complimenter. His response was " $\mathrm{mmm}$, maccobi- cobi mo tu, Sappo (you' re kidding me,Bro)" . This response tended to accept the compliment in agreeing utterance, return compliment and joke. Agreeing utterance and return compliment was based on Holmes' (1988, 1993) taxonomy, but joke was not find in Holmes (1988, 1993) taxonomy and it's 
also less in frequently used by American. The next datum was the female participant who gave response to male who delivered compliment or as complimenter. The topic of this compliment was personality traits. her response to the compliment was "makanja tongeng ga? (do you think so?)". They responsed the compliment by using avoid strategy. The other datum was the female participant who gave respons toward another female who as complimenter. The topic of the compliment was ability. The female participant's response was "de'to namakanja ladda bateku (I didn't do it well)". Her response tended to reject the compliment that was given to her. This response was based on Holmes (1988, 1993) taxonomy. These Bugiese data showed that the Buginese responses which were uttered by female and male were appearance, possessions, ability and personality traits of topic compliment. In Buginese data the result showed varied responses. A number of data followed the Holmes taxonomy of compliment and some of them were not. Such as, when Buginese responsed the compliment by joking which it wasnot existed in Holmes taxonomy. While Americans in responding the compliment had their own ways. It could be looked on the data. The first datum was between male (recipient of compliment) and female (complimenter). The topic of compliment was appearance. The response of this datum was "yeah, thank you". The next datum was about possession topic of compliment. This utterance was uttered by male (recipent of compliment) and another male (complimenter). His response showed the acceptanece as "humm, thanks". The next one was between female and male in ability topic of compliment. The response when she got a compliment from another male was "smiling and nodding" which indicated acceptance response. The datum about personality traits topic of compliment that the researcher found was "ouh, it's very ice of you to say so, thank you”. It showed the acceptance response as well. Based on the American data, in responding to compliment, American tend to accept the compliment rather than rejected or avoid. The way they response the compliment was based on Holmes taxonomy of compliment response. Once, in some case, they avoided or rejected the compliment as the researcher found " $n o, I$ don't think so" or avoiding "you really think so?". But it was less rejection frequently rather than accepting the compliment.

A compliment is a speech act which explicitly or implicitly attributes credit to someone other than the speaker, usually the person addressed, for some 'good' (possession, characteristic, skill, etc) which is positively valued by the speaker and the hearer ( Holmes' , 1986: 485). Compliment response is a verbal acknowledgement that the recipients of the compliment hear and react to the compliment (Nelson et al., 1996).

Holmes developed three categories of compliment responses; accept, reject and avoid. In acceptance, there were four micro levels, they were appreciation token, agreeing utterance, downgrading utterance and returning compliment. In rejection, there were three micro levels, they were disagreeing utterance, challenge sincerity and question accuracy. In avoidance, there were three micro level, they were shift credit, informative comment and request reassurance.

Both American and Buginese data were analysed based on Holmes' compliment response categories. The result of this research showed that both of speakers Buginese and American used three types of compliment responses; accept, avoid and reject. The response types between two groups were varied. According to Holmes (1988), American tended to response the compliment with simple way such as "thank you" to accept the compliment, or "no, thanks" to reject the compliment. But in Buginese, most of 
them used various responses either in acceptance, avoid or reject the compliment. A unique response which was delivered by Buginese when they were got praised or compliment by their interlocutor. Those responses were joke and social norms. These responses did not exist in Holmes taxonomy of compliment response categories. Buginese used joke response when they tried to accept the compliment but they did not want to be considered as a self - praise, therefore, they preferred to use joke. It could be seen in this data, the compliment was "makanja ladde' presntasi ta, de' na sala ko runtu'ki nilai matanre (good presentation, you deserve to get a good mark)" The response was 'hum, maccobi- cobi mo tu' bro (you are kidding me, Man)". Buginese tended to use this response in topic compliment of appearance.

Besides that, Buginese also responded the compliment which related to social norms. This response occurred mostly in personality traits topic compliment. It could be seen in the data, "you are very good boy/girl, we do not know how to thanks to you". The response was "de' to na marigaga to pada sitolong memang satu pada tta rupa tau (it's ok, we help each other). Buginese tended to use this response excessively in personality traits.

When Buginese Male got compliment from another Male, they tended to reject the compliment in topic of compliment possession. They rejected the compliment by using disagreeing utterance type. In topic of appearance, male tended to avoid the compliment. They avoided the compliment by using shift credit type. In topic of ablity, male tended to accept the compliment. They accepted the response by using return compliment type. In topic of personality traits, male tended to accept the compliment. They accept the compliment by using social norm type. When Buginese Male got compliment from female, they tended to reject the compliment in possession topic of compliment. They rejected the compliment by using disagreeing utterance type. In appearance topic of compliment, male tended to avoid the compliment. They avoided the compliment by using shift credit type. In ability topic of compliment, male tended to accept the compliment. In personality traits topic of compliment, male tended to accept the compliment. When female Buginese got compliment from male, they tended to accept the compliment in possession topic of compliment. In appearance topic of compliment, female tended to accept the compliment. In ability topic of compliment female tended to avoid the compliment. In personality traits, male tended to accept the compliment. When female Buginese got compliment from another female, they tended to accept the compliment in possession topic. In appearance topic of compliment, female tended to avoid the compliment. In ability topic, female tended to accept the compliment. In personality traits topic of compliment, female tended to accept the compliment. Different with Buginese, Female and Male Americans tended to accept the compliment almost in every topics of compliment. It based on the other compliment response by the other researchers in the past few years. American tended to accept the compliment and gave simple response. It could be seen in the data, "hi Josh, nice beard", and the response was "oh, thanks".

In the east culture, especially in Buginese, had different way in responding the compliment. Most of them responsed the compliment with rejection or avoided to give respectful or modesty responses and to minimized the praise which was given to them. Rejection responses by Buginese didn't mean that they disrespectedthe speaker or the one who gave compliment. It showed that Buginese had his/her own way to response the compliment and to honor the speaker.

The influence of culture is significantly affected the response of the 
compliment which was delivered by two groups (American and Buginese). In The exploration of Buginese ancestor revealed some philosophy or value as a basic of Buginese culture. It was bequeathed from one generation to the next generation. They were bequeathed by advising or giving them messages. In Buginese, it was called pasang. In doing social interaction, Buginese always hold on to message of sipakatau, sipakalebbi, and sipakainge or 3S. These three messages influence theirconversation cultural. Sipakatau means that we as human have to respect each other in any conditions without looking their position. Nowadays, the culture was found rarely in the society of Buginese. Sipakalebbi means that we have to give appreciate to other people. We have to give praise to someone who has excesses. Sipakainge' means we have to remain each other to build a good relation. Otherwise, American had a different culture and value with east culture especially in Buginese. American culture differed with Buginese which Buginese always pay attention with the politeness, the face and the feeling of the interlocutor. Americans didn't pay attention of that. Americans who lean on equality value believed that everyone is created equal and has the same rights. This valued was included women as well as men of all ethnic and cultural groups. Therefore in this research, either male or female American in responding the compliment they tended to response the compliment by simple response such as "thanks", "thank you" or "yes". It could be seen in the data 81: "wow, you are great skier" and the response is "thanks". Besides that, Americans also lean on informality value. It means that American lifestyle is generally casual, informal and friendly. In sum up, every country had unique strategies in responding the compliment. It depended on what the background culture they have whom they speak with and what the conditionin.

\section{CONCLUSIONS AND SUGGESTION}

According to previous findings and discussions, the researcher drew some conclusions. First, data of American compliment responses completely worked with the categories of compliment response that proposed by the theory. On the other side, the types of compliment responses in Buginese data were also realized by the category of compliment responses. However, there were some types of compliment responses uncovered by the theory. They were about joke and social norms. Second, data of American showed that there was no difference response strategies between female and male when theyresponsed the compliment. Both of them used simple response and they tended to accept the compliment in every topic of compliment. Meanwhile, Buginese female and male used difference strategies in responding the compliment. Last, the culture of two groups was very affect in responding the compliment. American tended to accept and respond the compliment by using simple way because they leant on their culture which was equality and informality. Meanwhile, Buginese leant on their own culture which called sipakatau, sipakalebbi, and sipakainge'. Based on the research finding above, there were several points thatcould be recommended to the reader such as; first,responsed the compliment should properly use according to the situation and background of culture. It actually should not use freely. Second, the readers should have good comprehension in analysing context. At last, for the next researchers who want to study about compliment response, they can explore more detail about compliment response especially in other variables such usage, education, and etc.

\section{BIBLIOGRAPHY}

Al- Falasi H. 2007. "Just Say Thank You: A Study of Compliment 
Totobuang, Vol. 6, No. 1, Juni 2018: 81—95

Responses." The Linguistic Journal, 2 (1): 28--42.

Chen R. 1993. "Responding to Compliments: A Contrastive Study of Politeness Strategies between American English and Chinese Speakers". Journal of Pragmatics, 20:49--75.

Basowet al.1992. Gender, $3^{\text {rd }}$ edtion. USA: Brooks/ Cole Publishing Company.

Brown,P\& Levinson, S. 1987. Politeness: Some Universals in Language Usage. Cambridge: Cambridge University Press.

Duan Y. 2011. A Pragmatic Research Report on Compliment Speech Act. Finland: Academy Publishers.

Ebadi\& Salman. 2015. "Using Compliment Responses in Arabic and English: Focusing on Male and Female EFL Learners in Iraq." Journal of Applied Linguistic and Language Research, 2 (7): 157178.

Fishman,J. A. 1972. The Sociology of

Language. Massachusetts:

Newbury House Publishers

Gajaseni,C. 1994. A contrastive study of compliment responses in American English and Thai including the effect of gender and social status.

Dissertation.University of Illinois at Urbana- Champaign.

Ghawi M. 1993. "Pragmatic Transfer in Arabic Learners of English." Journal of Pragmatics, 1 (1): 39-52.

Graddol, D. \& Swann, J. 1989. Gender Voices. Oxford: Brazil Blackwell.

Herbert, R.K. 1986. Ay "Say Thank You" - Or Something, American Speech, 61, 76--88.

Hiba. Q. \&Salasiah C. 2009. A study of Compliment Responses in English among Iraqi Postgraduates. USM.

Holmes J. 1988. "Paying Compliments: A Sex- Preferential Politeness Strategy." Journal of Pragmatics, 12 (4): 445--465.
Hymes, D. H. 1974. Foundations in

Sociolinguistics: An Ethnographic

Approach. Philadelphia: University of Pennsylvania Press.

Ibrahim \&Riyanto T. 2011. "A Sociolinguistic Study of

Compliment Responses Among Americans and Indonesians and Its Implications for Teaching English.” $K @$ ta, 2 (1): 21-30.

Katsuta H. 2012. The role of Compliment Response (Dissertation and Theses). Japan: Portland State University.

Leech, G. N. 1983. Principles of Pragmatics. New York: Longman Group Limited

Lorenzo- Dus. 2001. "Compliment response among British and Spanish University students: a contrastive Study", Journal Pragmatics, 33, 107--127.

Nelson,G. et al. 1996. "Arabic and English compliment responses: potential for pragmatic failure." Applied Linguistics, 17(4), 411--432.

Pomerantz, A. 1978. "Compliment Responses, Notes on The CoOperation of Multiple Constraints", in Schenkein, J. (ed.), Studies in the Organization of Conversational Interaction, pp.79--112, London: Academic Press.

Sadeghi \& Zarei. 2013. Investigating the Use of Compliments in Persian and English: A Case Study of Iranian EFL Students. Journal of Foreign Language Teaching and Translation Studies, 2 (2): 30--49.

Shahsavaria. et al. 2014. "Compliment Responses: A Comparative Study of Native English Speakers and Iranian L2 Speakers". Journal of Pragmatics, 98 (1): 1745--1753.

Sugiyono. 2010. Penelitian Kuantitatif, Kualitatif dan $R$ \& $D$. Bandung: Penerbit Alfabeta.

Thomas, J. 1995. Meaning in Interaction: an Introduction to Sociolinguistic, 
fifth edition. Massachussetts: Blackwell Publishing Ltd.

Wardhaugh, R. 1998. An Introduction to Sociolinguistics, fifth edition. Massachusetts: Blackwell Publishing Ltd.

Wu L. 2008. Gender-Based Differences in compliments (Elective Course: Language and Gender). Sweden: Kristiantad University.
Yule, G. 1996. Pragmatics. New York: Oxford University Press

Ziaei N. 2012. "Translation on the Basis of Frequency: Compliment and Compliment Responses". Translation Journal, 16 (3): 40-55. Retrieved on May $18^{\text {th }}, 2016$. Available from http://translationjournal.net/journal 61compliment.htm 



\begin{tabular}{|lcc|}
\hline & TOTOBUANG & \\
\hline Volume 6 & Nomor 1, Juni 2018 & Halaman 97-107 \\
\hline
\end{tabular}

\title{
KEMAMPUAN MENULIS TEKS PIDATO BERBAHASA INDONESIA DI SMA NEGERI 3 WAEAPO (The Ability of Writing Indonesian Speech at SMA Negeri 3 Waeapo)
}

\author{
Nanik Indrayani \\ Universitas Iqra Buru \\ Jalan Prof. Dr. H.A.R. Bassalamah, SE. M.Si, Namlea \\ Pos-el: nanikindra83@gmail.com
}

(Diterima: 18 Mei 2018; Direvisi: 30 Mei 2018; Disetujui: 3 Juni 2018)

\begin{abstract}
Writing speech is one of the students'favorite subjects at SMA Negeri 3 Waeapo, Pulau Buru. This study aimed to describe the students' capability in writing Indonesia speech. This research was classified as Classroom Action Research. The population of this study were 44 students of two classes of Class XII. Obtaining the accurated data, this research used written test suchas writting the speech text by using 'bahasa Indonesia yang baik dan benar' with theme that had been determined by the researcher. Then, the collected data would be analyzed by using descriptive quantitative. The results showed that only one of 44 students got less then 65. Thus, it can be concluded that students of Class XII of SMA Negeri 3 Waeapo Pulau Buru had capability to write the speech texts by using 'bahasa Indonesia yang baik dan benar' and achieving the completeness criteria by reaching more than 67 percent. This also could be seen in the score of other 43 students who got more than 65.

Keywords: Students, Speechtets, Indonesian Language.
\end{abstract}

\section{Abstrak}

Penulisan pidato merupakan salah satu mata pelajaran yang digemari sebagian siswa di SMA Negeri 3 Waeapo, Pulau Buru. Penelitian ini bertujuan untuk mendeskripsikan kemampuan siswa kelas XII dalam menulis pidato berbahasa Indonesia. Penelitian ini tergolong Penelitian Tindakan Kelas (Classroom Action Research). Populasi penelitian ini adalah siswa Kelas XII SMA Negeri 3 Waeapo Buru, yang terdiri atas dua kelas dan berjumlah 44 siswa. Untuk mendapatkan data yang akurat, penelitian ini menggunakan tes tertulis berupa teks pidato, dengan tema yang ditetapkan oleh peneliti, dalam bahasa Indonesia yang baik dan benar. Data yang telah dikumpulkan kemudian dianalisis dengan menggunakan deskriptif kuantitatif. Hasil penelitian menunjukan bahwa hanya 1 di antara 44 siswa yang dijadikan sampel penelitian memperoleh nilai di bawah 65. Dengan demikian, dapat disimpulkan bahwa siswa Kelas XII SMA Negeri 3 Waeapo Pulau Buru telah mampu menulis pidato dengan menggunakan bahasa Indonesia yang baik dan benar dan mencapai kriteria ketuntasan yang ditetapkan sebanyak 67 persen. Hal ini juga dibuktikan dengan perolehan nilai yang mencapai 65 ke atas yang diperoleh 43 siswa.

Kata-Kata Kunci: Siswa, teks pidato, berbahasa Indonesia.

\section{PENDAHULUAN}

Bahasa adalah kunci pokok bagi kehidupan manusia di atas dunia ini, karena dengan bahasa orang bisa berinteraksi dengan sesama dan bahasa merupakan sumber daya bagi kehidupan bermasyarakat. Adapun bahasa dapat digunakan apabila saling memahami atau saling mengerti, danerat hubungannya dengan penggunaan sumber daya bahasa yang kita miliki. Kita dapat memahami maksud dan tujuan orang lain berbahasa atau berbicara apabila kita mendengarkan dengan baik apa yang diakatakan. Untuk itu keseragaman berbahasa sangatlah penting, supaya ketika berkomunikasi berjalan lancar.

Menurut Tarigan (1986:21), menulis adalah suatu usaha menurunkan atau melukiskan lambang-lambang grafik yang menggambarkan suatu bahasa yang dipahami oleh seseorang, sehingga orang lain dapat membaca lambang-lambang grafik tersebut dan memahami bahasa dalam grafik itu. Natawijaya (1979:9) 
mendefinisikan menulis sebagai usaha untuk menyusun buah pikiran dan perasaan atau tanda-tanda informasi yang diperoleh melalui organisasi penulisan yang sistematis, sehingga tema karangan atau tulisan yang disampaikan mudah dipahami pembaca. Menulis merupakan kegiatan yang produktif dan ekspresif, dalam kegiatan ini seseorang penulis haruslah terampil memanfaatkan struktur bahasa. Keterampilan menulis ini tidak akan datang secara otomatis melainkan haruslah melalui latihan dan praktik yang banyak.

Pembelajaran bahasa Indonesia dalam kurikulum 2006 dijelaskan bahwa salah satu tujuan pengajaran bahasa Indonesia, menuntut agar siswa mampu mengungkapkan secara sistematis, logis, dan kreatif, pengalaman, gagasan, pesan, pendapat, dan perasaan sesuai dengan konteks dan situasi. Untuk mewujudkan tujuan tersebut harus didukung oleh penguasaan bidang kebahasaan seperti penguasaan terhadap penggunaan bahasa Indonesia yang baik dan benar dalam menulis teks pidato. Siswa diharapkan mampu menulis teks pidato dengan menggunakan bahasa yang baik dan benar, baik dalam bentuk tertulis maupun lisan. Depdiknas, (2001:2) menyatakan dalam pembelajaran, masalah menulis teks pidato yang sering ditemukan yakni masih banyak siswa yang belum mampu menggunakan bahasa yang baik maupun secara benar, terutama dalam menulis teks pidato. Pateda (Alwi, 1997:30) mengatakan bahwa, "Kita berusaha agar dalam situasi resmi kita harus berbahasa yang baku. Begitu juga dalam situasi yang tidak resmi kita berusaha menggunakan bahasa yang baku."

Menurut Daryanto (1997:156), "Kata keterampilan berasal dari kata terampil yang mendapat imbuhan ke-an membentuk kata benda yang berarti, kecakapan untuk menyelesaiakan tugas kecekatan". Sedangkan pidato adalah menyampaikan pikiran dalam bentuk kata-kata kepada orang lain. Keterampilan pidato merupakan kecakapan dalam menyampaikan kata-kata kepada orang lain secara lisan. Menulis teks pidato dengan terampil haruslah dengan tahap pelatihan menulis dengan proses mengekspresikan diri, menyumbangkan kecerdasan, mengembangkan daya inisiatif dan kreativitas, mengasah kecerdasan dan proses berkomunikasi. Proses tersebut menjadikan keterampilan menulis teks pidatopun dapat terlaksana dengan baik.

Dari uraian pendapat diatas tentang pidato, dapat disimpulkan bahwa berbicara sangat berperan dihadapan suatu kelompok masa. Dan seseorang yang memiliki keterampilan berbicara akan dapat dengan mudah menyampaikan ide dan gagasannya kepada orang lain, dan diduga ia akan berhasil mengemukakan gagasan itu sehingga dapat diterima oleh orang lain, dan untuk mewujudkan itu diperlukan langkahlangkah yang telah diuraikan diatas.

Berbahasa Indonesia yang baik adalah menggunakan bahasa Indonesia yang sesuai konteks (pembicaraan atau penulisan). Berbahasa Indonesia yang benar adalah menggunakan bahasa Indonesia yang sesuai dengan kaidah (tata bahasa) bahasa Indonesia. Bahasa Indonesia yang baik dan benar adalah bahasa Indonesia yang digunakan sesuai dengan situasi pembicaraan (yakni sesuai dengan lawan bicara, tempat pembicaraan, dan ragam pembicaraan) dan sesuai dengan kaidah yang berlaku dalam Bahasa Indonesia (seperti sesuai dengan kaidah ejaan, pungtuasi, istilah, dan tata bahasa).

Keraf (1980:318) dalam buku komposisi, mengatakan bahwa untuk memiliki kemampuan berpidato yang baik, diperlukan persiapan sebaik-baiknya dan latihan secara teratur. Seseorang berpidato berarti memberi informasi atau menyampaikan suatu pengetahuan kepada orang banyak.

Penggunaan bahasa Indonesia yang baik dan benar, khususnya dalam menulis teks pidato merupakan salah satu kegiatan utama dalam rangka meningkatkan daya 
imajinasi seseorang. Kegiatan tersebut perlu diperhatikan oleh para guru khususnya guru bahasa Indonesia agar siswa dapat berpikir untuk mewujudkan apa yang ada dalam pikirannya melalui kegiatan menulis teks pidato dengan menggunakan bahasa Indonesia secara baik dan benar.

Sesuai dengan hasil pra-penelitian peneliti dengan guru Bahasa Indonesia, di SMA Negeri 3 Waeapo Pulau Buru khususnya kelas XII ditemukan bahwa masih banyak siswa yang belum menyadari pentingnya penggunaan bahasa Indonesia yang baik dan benar dalam menulis teks pidato bahasa Indonesia maupun dalam kegiatan belajar mengajar di kelas. Banyak siswa di sekolah tersebut khususnya kelas XII masih menggunakan bahasa Indonesia bercampur dengan bahasa daerah ketika menulis teks pidato dalam mata pelajaran Bahasa Indonesia.

\section{METODE}

\section{Jenis dan Desain Penelitian}

Berdasarkan judul penelitian ini, yakni Kemampuan Menulis Teks Pidato Berbahasa Indonesia di SMA Negeri 3 Waeapo, peneliti ingin mengetahui berapa banyak jumlah siswa yang masih menggunakan bahasa Indonesia bercampur dengan bahasa daerah dalam menulis teks pidato.

Penelitian ini digolongkan ke dalam Penelitian Tindakan Kelas (Classroom Action Research), yaitu suatu bentuk kajian yang bersifat reflektif, yang dilakukan oleh pelaku tindakan untuk meningkatkan kemantapan rasional dari tindakantindakannya dalam melaksanakan tugas dan memperdalam pemahaman terhadap kondisi dalam praktik pembelajaran Hopkins dalam Muslich, (2010:8). Penelitian ini menggunakan pendekatan kuantitatif. Sementara itu, jenis penelitian ini adalah deskriptif. Jenis penelitian deskriptif dipilih karena sesuai dengan tujuan penelitian, yaitu untuk mendapatkan data mengenai kemampuan siswa dalam menulis teks pidato dengan menggunakan bahasa Indonesia yang baik dan benar. Pemerolehan informasi dan data dijelaskan apa adanya sesuai dengan fakta yang ada di lapangan.

Desain penelitian yang digunakan dalam penelitian ini adalah deskriptif kuantitatif, yakni mengumpulkan, mengelola, menganalisis, dan menyajikan data secara objektif mengenai objek penelitian, yaitu kemampuan siswa dalam menulis teks pidato bahasa Indonesia dengan penggunaan bahasa Indonesia yang baik dan benar pada siswa kelas XII SMA Negeri 3 Waeapo Pulau Buru.

\section{Definisi Operasional Variabel}

Untuk menghindari dari penafsiran yang berlebihan terhadap penulisan ini, penulis memberikan batasan istilah yang masih berkaitan dengan judul ini, sebagai berikut 1) Kemampuan berarti kesanggupan, kecakapan, kekuatan untuk melakukan sesuatu. 2) Kemampuan menulis adalah kemampuan menggunakan bahasa Indonesia yang baik dan benar yang dituangkan dalam tulisan atau teks. 3) Pidato adalah salah satu ragam berbicara dalam bentuk lisan yang ditunjukkan kepada khalayak.

\section{Populasi dan Sampel}

Populasi disebut juga keseluruhan semesta (universal) dan dapat didefinisikan sebagai semua anggota dari satu kesatuan orang. Kejadian atau benda yang kita jadikan sasaran generalisasi hasil penelitian kita menurut Borg dan Gali dalam Suharto (2008:64).

Sampel adalah sebagian atau wakil dari populasi yang akan diteliti. Sampel dalam penelitian ini mengacu pada pendapat Arikunto (2010:43) bahwa apabila populasi kurang dari 100 maka lebih baik diambil semuanya sehingga penelitiannya merupakan penelitian populasi. Jika jumlah subjeknya lebih dari 100 dapat diambil antara $10-15 \%$ atau $20-25 \%$ atau lebih tergantung situasi, kondisi, dan kebutuhan. 
Berdasarkan pendapat tersebut, maka populasi dalam penelitian ini adalah keseluruhan siswa kelas XII SMA Negeri 3 Waeapo Tahun Ajaran 2017/2018. Jumlah subjek dalam penelitian ini terdiri atas satu kelas yang berjumlah 44 siswa dengan rincian laki-laki 25 orang dan perempuan 19 orang.

Populasi dalam penelitian ini bersifat heterogen, yaitu setiap kelas memiliki kemampuan yang berbeda. Pembagian kelas berdasarkan jumlah kelas yang ada, untuk mendapatkan sampel yang representatif, penarikan dengan stratified random sampling, yakni penarikan sampel dengan memerhatikan tingkat kemampuan siswa. Kemampuan yang dimaksud adalah kemampuan berbahasa Indonesia. Kemampuan ini diambil dari penggunaan bahasa Indonesia yang baik dan benar dalam menulis teks pidato, dan diambil dari nilai rapor khususnya mata pelajaran bahasa Indonesia. Dengan demikian penelitian ini termasuk penelitian populasi Arikunto (2010:43).

\section{Instrumen Penelitian}

Penelitian ini menggunakan instrumen tes kemampuan menulis teks pidato. Instrumen yang digunakan adalah teks berupa pidato kebersihan lingkungan, pidato perpisahan kelulusan sekolah, pidato penyalahgunaan narkoba. Instrumen tersebut disodorkan kepada siswa untuk menulis. Penilaian merupakan langkah pertama dalam proses pengolahan hasil tes menulis siswa. Dalam hal ini, penilaian adalah suatu proses pengubahan hasil menulis teks menjadi angka.

Waktu yang disediakan bagi siswa untuk mengerjakan tes adalah 2 jam pelajaran, yang berarti $2 \times 45$ menit $=90$ menit. Selama pengumpulan data, peneliti memohon bantuan guru Bahasa Indonesia di sekolah tempat penelitian. Hal ini dilakukan dengan maksud agar situasi dan kondisi tetap dalam keadaan wajar, tidak mengalami perubahan yang berarti atau sesuai dengan keadaan seperti biasa ketika dalam menerima pelajaran.

Maka instrumen yang digunakan dalam penelitian ini adalah berupa tes unjuk kerja yaitu tes kemampuan siswa dalam menulis teks pidato, untuk memudahkan subjek yang diteliti dalam menulis teks pidato. Maka instrumen penelitian dilengkapi petunjuk pengerjaan tugas yang telah dirumuskan, yaitu buatlah sebuah teks pidato dengan ketentuan sebagai berikut 1 . Tulislah nama dan kelas di kertas yang telah disediakan. 2. Tulislah salah satu teks pidato dengan topik berikut a) kebersihan lingkungan, b) perpisahan kelulusan sekolah, c) penyalahgunaan narkoba. 3. Tulis dengan panjang tulisan 4-8 paragraf. 4. Waktu menulis 90 menit.

\section{Teknik Pengumpulan Data}

Untuk memeroleh data yang akurat tentang kemampuan menulis teks pidato dengan menggunakan bahasa Indonesia yang baik dan benar siswa kelas XII SMA Negeri 3 Waeapo, Hasil pemberian tugas menulis teks pidato kepada responden itulah data yang diperoleh dalam penelitian ini. penulis menggunakan tes sebagai instrumen penelitian.

\section{Teknik Analisis Data}

Data yang diperoleh melalui tes akan diolah dan dianalisis dengan langkahlangkah sebagai berikut 1) Membuat daftar skor mentah. 2) Membuat distribusi frekuensi dan skor mentah. 3) menentukan nilai baku setiap sampel dengan menggunakan rumus

$\mathrm{P}=\underline{\mathrm{Fg}} \times 100$

$\mathrm{N}$

Keterangan:

$\mathrm{P}$ : Persentase.

Fg: Jumlah jawaban benar.

$\mathrm{N}$ : Jumlah skor maksimal 4. menghitung nilai rata-rata yang diperoleh siswa dengan menggunakan sebagai berikut:

$\mathrm{X}=\sum \mathrm{X} \times 100$ 


\author{
$\mathrm{N}$ \\ Keterangan: \\ $\mathrm{X}=$ Nilai rata-rata \\ $\sum \mathrm{X}=$ Jumlah jawaban keseluruhan \\ $\mathrm{N}=$ Banyaknya subjek
}

\section{PEMBAHASAN}

\section{Hasil Penelitian}

Berdasarkan hasil penelitian dan analisis data diatas, maka dapat diuraikan secara rinci tentang kemampuan menulis teks pidato siswa Kelas XII SMA Negeri 3 Waeapo. Penelitian ini merupakan penelitian yang bersifat deskriptif kuantitatif yang bertujuan mendeskripsikan kemampuan menyusun teks pidato pada siswa Kelas XII SMA Negeri 3 Waeapo. Untuk mengetahui kemampuan menulis teks pidato pada siswa Kelas XII SMA Negeri 3 Waeapo, siswa diberikan tes untuk menulis dengan menggunakan bahasa Indonesia yang baik dan benar. Hasil tes tersebut diperiksa berdasarkan kriteria dan indikator penilaian teks pidato yang telah dibuat yaitu kesesuaian judul dengan tema, penulisan ejaan, penulisan huruf kapital, diksi atau pilihan kata, penulisan struktur, dan kerapian tulisan.

Kemampuan menulis teks pidato pada siswa kelas XII SMA Negeri 3 Waeapo dikategorikan sudah memadai. Perolehan nilai sebagai standar keberhasilan sudah mencapai standar yang ditetapkan yaitu $7.75 \%$ siswa yang mencapai nilai di atas 67 .

Berdasarkan hasil tes, skor mentah yang diperoleh siswa sangat bervariasi, yaitu:

\section{Tabel 1}

Variasi Skor Perolehan Siswa

\begin{tabular}{|c|c|c|c|}
\hline No. & Nilai & Frekuensi & Persentase \\
\hline 1. & 80 & 7 & 15,90 \\
\hline 2. & 79 & 4 & 9,01 \\
\hline 3. & 78 & 6 & 13,63 \\
\hline 4. & 75 & 8 & 18,18 \\
\hline 5. & 69 & 6 & 13,63 \\
\hline 6. & 68 & 7 & 15,90 \\
\hline 7. & 67 & 5 & 11,36 \\
\hline
\end{tabular}

\begin{tabular}{|c|c|c|c|}
\hline 8. & 65 & 1 & 2,27 \\
\hline \multicolumn{2}{|c|}{ Jumlah } & 44 siswa & $100 \%$ \\
\hline
\end{tabular}

Kategorisasi tes tingkat kemampuan, frekuensi dan persentase tes hasil belajar kemampuan menulis teks pidato pada siswa Kelas XII SMA Negeri 3 Waeapo menunjukkan bahwa, tidak ada siswa yang berada pada kategori sangat tinggi $(0 \%)$, siswa yang berada pada kategori tinggi diperoleh 43 siswa (97.77\%), dan tidak ada siswa yang berada pada kategori sedang $(0 \%)$, dan siswa yang berada pada kategori rendah diperoleh 1 siswa (2.23\%) dan tidak ada siswa yang berada pada kategori sangat rendah $(0 \%)$.

Hasil analisis statistik deskriptif yang berkaitan dengan nilai tes kemampuan menulis teks pidato dengan menggunakan bahasa Indonesia yang baik dan benar pada siswa Kelas XII SMA Negeri 3 Waeapo, bahwa dari 44 siswa yang dijadikan sampel penelitian untuk pembelajaran menulis teks pidato dengan menggunakan bahasa Indonesia yang baik dan benar siswa Kelas XII SMA Negeri 3 Waeapo, nilai ideal 100, perolehan nilai tertinggi yaitu 80 , nilai tengah 68 , nilai terendah 65 , dan nilai ratarata kelas 7.75 .

Berdasarkan nilai statistik tes hasil belajar menulis teks pidato dengan menggunakan bahasa Indonesia yang baik dan benar pada siswa Kelas XII SMA Negeri 3 Waeapo bahwa hasil tes belajar menulis teks pidato dengan menggunakan bahasa Indonesia yang baik dan benar pada siswa kelas XII SMA Negeri 3 Waeapo yang diperoleh nilai 67 ke atas berjumlah 43 siswa atau $(97.77 \%)$ dan sampel yang memperoleh nilai di bawah 67 berjumlah 1 siswa (2.23\%). Hal ini membuktikan bahwa nilai yang diperoleh siswa Kelas XII SMA Negeri 3 Waeapo sebesar 65 ke atas telah mencapai kriteria tingkat kemampuan siswa yaitu di atas 67.

Berdasarkan hasil belajar menulis teks pidato dengan menggunakan bahasa 
Indonesia yang baik dan benar pada siswa Kelas XII SMA Negeri 3 Waeapo, peneliti dapat menyimpulkan bahwa siswa mampu menulis teks pidato dengan menggunakan bahasa Indonesia yang baik dan benar.

\section{Pembahasan Hasil Penelitian}

Dalam penelitian ini dideskripsikan secara rinci hasil penelitian tentang kemampuan menulis teks pidato dengan menggunakan bahasa Indonesia yang baik dan benar pada siswa kelas XII SMA Negeri 3 Waeapo. Hasil penelitian ini merupakan hasil kuantitatif, yaitu uraian yang menggambarkan kemampuan menulis teks pidato dengan menggunakan bahasa Indonesia yang baik dan benar pada siswa Kelas XII SMA Negeri 3 Waeapo yang dinyatakan dengan angka.

Data penelitian ini dikumpulkan dengan cara memberikan tugas berupa tes tertulis kepada siswa, yaitu tes menulis teks pidato dengan tema yang ditetapkan oleh peneliti. Setelah kegiatan tersebut selesai, pekerjaan siswa dikumpulkan kemudian diberi kode. Selanjutnya diadakan penilaian terhadap pekerjaan siswa. Adapun aspekaspek yang dinilai meliputi1) kesesuaian judul atau tema, 2) penulisan ejaan,3) penulisan huruf kapital, 4) diksi atau pilihan kata, 5) penulisan struktur, 6) kerapian tulisan.

Setiap aspek tersebut dinilai dengan menggunakan rentang skor yang telah ditetapkan dalam bab III, sehingga pada akhirnya dapat ditemukan dan ditentukan berapa skor siswa untuk setiap aspek serta berapa jumlah total skor siswa untuk keseluruhan aspek.

Data yang diperoleh dalam penelitian ini diolah dan dianalisis menurut teknik dan prosedur yang dikemukakan pada bagian sebelumnya. Data yang diolah dan dianalisis adalah data skor mentah hasil tes kemampuan menulis teks pidato dengan menggunakan bahasa Indonesia yang baik dan benar siswa kelas XII SMA Negeri 3 Waeapo. Adapun langkah-langkah dalam menganalisis data, yaitu membuat daftar skor mentah dan membuat distribusi frekuensi dari skor mentah. Untuk lebih jelasnya, pada tabel berikut disajikan skor kemampuan siwa dalam menulis teks pidato untuk setiap aspek yang dinilai.

\section{Tabel 2}

Skor Mentah Kemampuan Siswa Menulis Teks Pidato dengan Menggunakan Bahasa Indonesia yang Baik dan Benar

\begin{tabular}{|l|l|l|l|l|l|l|l|}
\hline $\begin{array}{l}\text { Kode } \\
\text { siswa }\end{array}$ & KJ & PE & PH & D & PS & KT & TOTAL \\
\cline { 2 - 8 } & $\begin{array}{l}0- \\
10\end{array}$ & $\begin{array}{l}0- \\
10\end{array}$ & $\begin{array}{l}0- \\
10\end{array}$ & $\begin{array}{l}0- \\
10\end{array}$ & $\begin{array}{l}0- \\
10\end{array}$ & $\begin{array}{l}0- \\
10\end{array}$ & \\
\hline S1 & 8 & 9 & 9 & 6 & 9 & 7 & 48 \\
\hline S2 & 9 & 7 & 8 & 9 & 9 & 9 & 51 \\
\hline S3 & 6 & 8 & 9 & 9 & 7 & 9 & 48 \\
\hline S4 & 9 & 9 & 7 & 7 & 6 & 8 & 46 \\
\hline S5 & 6 & 7 & 9 & 9 & 8 & 9 & 48 \\
\hline S6 & 8 & 8 & 6 & 6 & 9 & 9 & 46 \\
\hline S7 & 7 & 7 & 9 & 9 & 8 & 7 & 47 \\
\hline S8 & 9 & 9 & 8 & 8 & 9 & 9 & 52 \\
\hline S9 & 8 & 8 & 9 & 9 & 6 & 8 & 48 \\
\hline S10 & 7 & 7 & 8 & 6 & 9 & 6 & 43 \\
\hline S11 & 7 & 8 & 9 & 9 & 6 & 8 & 47 \\
\hline S12 & 9 & 9 & 7 & 8 & 9 & 9 & 51 \\
\hline S13 & 8 & 7 & 9 & 9 & 7 & 8 & 48 \\
\hline S14 & 6 & 9 & 8 & 8 & 9 & 6 & 46 \\
\hline S15 & 5 & 8 & 7 & 9 & 8 & 9 & 46 \\
\hline S16 & 9 & 9 & 6 & 8 & 9 & 7 & 48 \\
\hline S17 & 8 & 8 & 9 & 6 & 6 & 8 & 45 \\
\hline S18 & 9 & 9 & 8 & 9 & 9 & 8 & 52 \\
\hline S19 & 7 & 7 & 9 & 6 & 8 & 7 & 44 \\
\hline & & & & & & & \\
\hline
\end{tabular}

\begin{tabular}{|l|l|l|l|l|l|l|l|}
\hline S20 & 8 & 6 & 6 & 7 & 8 & 9 & 44 \\
\hline S21 & 9 & 8 & 7 & 7 & 6 & 9 & 46 \\
\hline S22 & 6 & 9 & 8 & 8 & 9 & 7 & 47 \\
\hline S23 & 8 & 8 & 6 & 9 & 9 & 8 & 48 \\
\hline S24 & 6 & 9 & 9 & 8 & 8 & 9 & 49 \\
\hline 25 & 9 & 6 & 7 & 9 & 9 & 6 & 46 \\
\hline S26 & 8 & 8 & 7 & 8 & 8 & 9 & 48 \\
\hline S27 & 7 & 6 & 9 & 9 & 8 & 8 & 47 \\
\hline S28 & 6 & 6 & 8 & 8 & 9 & 8 & 45 \\
\hline S29 & 9 & 9 & 7 & 6 & 8 & 8 & 47 \\
\hline S30 & 9 & 9 & 7 & 8 & 9 & 9 & 51 \\
\hline S31 & 6 & 7 & 9 & 9 & 8 & 8 & 47 \\
\hline S32 & 8 & 8 & 7 & 7 & 6 & 9 & 45 \\
\hline S33 & 8 & 9 & 9 & 8 & 7 & 8 & 49 \\
\hline S34 & 8 & 6 & 9 & 9 & 8 & 9 & 49 \\
\hline S35 & 6 & 6 & 8 & 8 & 7 & 8 & 43 \\
\hline S36 & 7 & 7 & 9 & 9 & 7 & 9 & 48 \\
\hline S37 & 7 & 8 & 8 & 9 & 9 & 7 & 48 \\
\hline
\end{tabular}




\begin{tabular}{|l|l|l|l|l|l|l|l|}
\hline S38 & 6 & 9 & 9 & 7 & 7 & 8 & 46 \\
\hline S39 & 6 & 7 & 7 & 9 & 9 & 7 & 45 \\
\hline S40 & 9 & 9 & 6 & 7 & 7 & 9 & 47 \\
\hline S41 & 8 & 8 & 9 & 9 & 8 & 6 & 48 \\
\hline S42 & 8 & 8 & 7 & 6 & 9 & 9 & 47 \\
\hline S43 & 8 & 6 & 9 & 7 & 8 & 8 & 46 \\
\hline S44 & 9 & 9 & 6 & 8 & 7 & 8 & 47 \\
\hline $\begin{array}{l}\text { Jumla } \\
\text { h }\end{array}$ & $\begin{array}{l}33 \\
4\end{array}$ & $\begin{array}{l}34 \\
4\end{array}$ & $\begin{array}{l}34 \\
7\end{array}$ & $\begin{array}{l}34 \\
9\end{array}$ & $\begin{array}{l}34 \\
9\end{array}$ & $\begin{array}{l}35 \\
4\end{array}$ & $\begin{array}{l}2.07 \\
5\end{array}$ \\
\hline
\end{tabular}

Pada tabel tersebut jelas terlihat bahwa untuk aspek kesesuaian Judul (KJ) diperoleh nilai dengan rentang skor $0-10$. Skor tertinggi diperoleh siswa adalah skor 9 dan terendah adalah 5. Skor 9 diperoleh 12 siswa, yakni S2, S4, S8, S12, S16, S18, S21, S25, S29, S30, S40, S44. Skor 8 diperoleh sampel S1, S6, S9, S13, S17, S20, S23, S26, S32, S33, S34, S41, S42, S43. Skor 7 diperoleh sampel S7, S10, S11, S19, S27, S36, S37. Skor 6 diperoleh sampel S3, S5, S14, S22, S24, S28, S31, S35, S38, S39. Skor 5 diperoleh sampel S15. Secara umum untuk skor kemampuan menggunakan kesesuaian judul diperoleh siswa sampel adalah 334 .

Untuk aspek kesesuaian Penulisan Ejaan (PE) diperoleh nilai dengan rentang skor $0-10$. Skor tertinggi diperoleh siswa sampel adalah skor 9 dan terendah adalah 6 . Skor 9 diperoleh sampel S1, S4, S8, S12, S14, S16, S18, S22, S24, S29, S30, S33, S38, S40, S44. Skor 8 diperoleh sampel S3, S6, S9, S11, S15, S17, S21, S23, S26, S32, S37, S41, S42. Skor 7 diperoleh sampel S2, S5, S7, S10, S13, S19, S31, S36, S39. Skor 6 diperoleh sampel S20, S25, S27, S28, S34, S35, S43. Secara umum untuk skor kemampuan menggunakan ejaan diperoleh siswa sampel adalah 344 .

Aspek Penulisan Huruf (PH) kapital diperoleh nilai dengan rentang skor $0-10$. Skor tertinggi diperoleh siswa sampel adalah skor 9 dan terendah adalah 6. Skor 9 diperoleh sampel S1, S3, S5, S7, S9, S11, S13, S17, S19, S24, S27, S31, S33, S34, S36, S41, S43. Skor 8 diperoleh sampel S2, S8, S10, S14, S18, S22, S28, S35, S37. Skor
7 diperoleh sampel S4, S12, S15, S21, S25, S26, S29, S30, S32, S39, S43. Skor 6 diperoleh sampel S6, S16, S20, S23, S40, S44. Secara umum untuk skor kemampuan menggunakan huruf kapital diperoleh siswa sampel adalah 347.

Aspek Diksi (D) diperoleh nilai dengan rentang skor $0-10$. Skor tertinggi diperoleh siswa sampel adalah skor 9 dan terendah adalah 6. skor 9 diperoleh sampel S2, S3, S5, S7, S9, S11, S13, S15, S18, S23, S25, S27, S31, S34, S36, S37, S39, S41. Skor 8 diperoleh sampel S8, S12, S14, S16, S22, S24, S26, S28, S30, S33, S35, S44. Skor 7 diperoleh sampel S4, S20, S21, S32, S38, S40, S43. Skor 6 diperoleh sampel S1, S6, S10, S17, S19, S29, S42. Secara umum untuk skor kemampuan menggunakan diksi diperoleh siswa 349.

Aspek Penulisan Struktur (PS) diperoleh nilai dengan rentang skor $0-10$. skor tertinggi diperoleh siswa sampel adalah skor 9 dan terendah adalah 6. Skor 9 diperoleh sampel S1, S2, S6, S8, S10, S12, S14, S16, S18, S22, SS23, S25, S28, S30, S37, S39, S42. Skor 8 diperoleh sampel S5, S7, S15, S19, S20, S24, S26, S27, S29, S31, S34, S41, S43. Skor 7 diperoleh sampel S3, S13, S33, S35, S36, S38, S40, S44. Skor 6 diperoleh sampel S4, S9, S11, S17, S21, S32. Secara umum untuk skor kemampuan struktur diperoleh siswa sampel adalah 349.

Aspek Kerapian Tulisan (KT) diperoleh nilai dengan rentang skor $0-10$. Skor tertinggi diperoleh siswa sampel adalah 9 dan terendah adalah 6. Skor 9 diperoleh sampel S2, S3, S5, S6, S8, S12, S15, S20, S21, S24, S26, S30, S32, S34, S36, S40, S42. Skor 8 diperoleh sampel S4, S9, S11, S13, S17, S18, S23, S27, S28, S29, S31, S33, S35, S38, S43, S44. Skor 7 diperoleh sampel S1, S7, S16, S19, S22, S37, S39. Skor 6 diperoleh sampel S10, S14, S25, S41. Secara umum untuk skor kemampuan kerapian tulisan diperoleh siswa sampel adalah 354 .

Berdasarkan hasil perolehan skor mentah dalam tes awal siswa kelas XII SMA 
Negeri 3 Waeapo, maka dapat distribusi ke bentuk frekuensi dan persentase yang tertera pada tabel berikut ini.

Tabel 3

Distribusi Frekuensi dan Persentase Hasil Tes Siswa

\begin{tabular}{|c|c|c|c|}
\hline No. & Nilai & Frekuensi & Persentase \\
\hline 1. & 52 & 2 & 4,55 \\
\hline 2. & 51 & 3 & 6,88 \\
\hline 3. & 49 & 3 & 6,88 \\
\hline 4. & 48 & 11 & 25 \\
\hline 5. & 47 & 9 & 20,4 \\
\hline 6. & 46 & 8 & 18,18 \\
\hline 7. & 45 & 4 & 9,01 \\
\hline 8. & 44 & 2 & 4,55 \\
\hline 9. & 43 & 2 & 4,55 \\
\hline \multicolumn{2}{|l|}{ Jumlah } & 44 siswa & $100 \%$ \\
\hline
\end{tabular}

Berdasarkan penjabaran tersebut dengan keenam aspek penilaian adalah sebagai berikut, nilai tertinggi 52 diperoleh 2 siswa atau $(4,55 \%)$, nilai 51 diperoleh 3 siswa atau $(6,88 \%)$, nilai 49 diperoleh 3 siswa atau $(6,88 \%)$, nilai 48 diperoleh 11 siswa atau (25\%), nilai 47 diperoleh 9 siswa atau $(20,4 \%)$, nilai 46 diperoleh 8 siswa atau $(18,18 \%)$, nilai 45 diperoleh 4 siswa atau $(9,01 \%)$, nilai 44 diperoleh 2 siswa atau $(4,55 \%)$, nilai 43 diperoleh 2 siswa atau $(4,55 \%)$.

Berikut ini akan penulis sajikan data setelah dilakukan penelitian dan diberikan perlakuan terhadap siswa kelas XII SMA Negeri 3 Waeapo.

Tabel 4

Skor Kemampuan Siswa Menulis Teks

Pidato dengan Menggunakan Bahasa Indonesia yang Baik dan Benar

\begin{tabular}{|c|l|l|l|l|l|l|l|}
\hline $\begin{array}{l}\text { Kode } \\
\text { Siswa }\end{array}$ & KJ & PE & PH & D & PS & KT & $\begin{array}{c}\text { TOTA } \\
\text { L }\end{array}$ \\
\cline { 2 - 7 } & $10-$ & $10-$ & $10-$ & $10-$ & $10-$ & $10-$ & \\
& 15 & 15 & 15 & 15 & 15 & 15 & \\
\hline 1. & 15 & 14 & 13 & 14 & 10 & 14 & 80 \\
\hline 2. & 14 & 15 & 12 & 14 & 13 & 10 & 78 \\
\hline 3. & 13 & 10 & 14 & 15 & 14 & 13 & 79 \\
\hline
\end{tabular}

\begin{tabular}{|c|l|l|l|l|l|l|l|}
\hline 4. & 12 & 13 & 14 & 10 & 15 & 14 & 78 \\
\hline 5. & 13 & 10 & 14 & 15 & 13 & 10 & 75 \\
\hline 6. & 14 & 14 & 15 & 14 & 10 & 13 & 80 \\
\hline 7. & 12 & 10 & 11 & 10 & 12 & 10 & 65 \\
\hline 8. & 12 & 13 & 14 & 10 & 15 & 14 & 78 \\
\hline 9. & 13 & 11 & 10 & 12 & 11 & 10 & 67 \\
\hline 10. & 15 & 14 & 13 & 14 & 10 & 14 & 80 \\
\hline 11. & 15 & 14 & 13 & 13 & 10 & 14 & 79 \\
\hline 12. & 15 & 14 & 12 & 13 & 14 & 10 & 78 \\
\hline 13. & 15 & 13 & 10 & 13 & 10 & 14 & 75 \\
\hline 14. & 13 & 12 & 13 & 10 & 11 & 10 & 69 \\
\hline 15. & 13 & 10 & 10 & 14 & 10 & 11 & 68 \\
\hline 16. & 15 & 11 & 14 & 14 & 10 & 12 & 76 \\
\hline 17. & 12 & 11 & 10 & 13 & 11 & 10 & 67 \\
\hline 18. & 14 & 14 & 15 & 14 & 10 & 13 & 80 \\
\hline 19. & 13 & 11 & 14 & 10 & 11 & 10 & 69 \\
\hline 20. & 14 & 15 & 13 & 10 & 13 & 10 & 75 \\
\hline 21. & 14 & 10 & 10 & 13 & 10 & 11 & 68 \\
\hline 22. & 14 & 15 & 14 & 13 & 13 & 10 & 79 \\
\hline 23. & 14 & 15 & 13 & 13 & 10 & 10 & 75 \\
\hline 24. & 13 & 10 & 13 & 10 & 13 & 12 & 69 \\
\hline 25. & 15 & 13 & 14 & 14 & 12 & 10 & 78 \\
\hline 26. & 14 & 14 & 15 & 13 & 10 & 12 & 78 \\
\hline 27. & 13 & 12 & 11 & 10 & 11 & 10 & 67 \\
\hline 28. & 11 & 13 & 10 & 13 & 10 & 12 & 69 \\
\hline 29. & 15 & 14 & 13 & 10 & 13 & 10 & 75 \\
\hline 30. & 13 & 10 & 11 & 14 & 10 & 10 & 68 \\
\hline 31. & 12 & 11 & 13 & 10 & 11 & 10 & 67 \\
\hline 32. & 14 & 15 & 14 & 14 & 10 & 13 & 80 \\
\hline 33. & 14 & 15 & 13 & 10 & 13 & 10 & 75 \\
\hline 34. & 13 & 10 & 10 & 14 & 10 & 11 & 68 \\
\hline 35. & 15 & 14 & 10 & 13 & 10 & 10 & 75 \\
\hline 36. & 13 & 10 & 14 & 15 & 14 & 13 & 79 \\
\hline 37. & 13 & 13 & 10 & 12 & 11 & 10 & 69 \\
\hline 38. & 15 & 14 & 13 & 14 & 10 & 14 & 80 \\
\hline 39. & 14 & 10 & 10 & 10 & 13 & 11 & 68 \\
\hline 40. & 15 & 13 & 10 & 14 & 10 & 10 & 75 \\
\hline 41. & 13 & 12 & 11 & 11 & 10 & 10 & 67 \\
\hline 42. & 14 & 13 & 14 & 15 & 14 & 10 & 80 \\
\hline 43. & 13 & 13 & 12 & 10 & 10 & 11 & 69 \\
\hline 44. & 14 & 10 & 10 & 13 & 10 & 11 & 68 \\
\hline Jum- & 59 & 51 & 50 & 53 & 48 & 48 & 324 \\
\hline lah & 0 & 9 & 8 & 9 & 0 & 8 & 3 \\
\hline & & & & & & \\
\hline
\end{tabular}

Berdasarkan hasil perolehan data setelah dilakukan penelitian dan diberikan perlakuan terhadap siswa kelas XII SMA Negeri 3 Waeapo, maka dapat distribusi ke bentuk frekuensi dan persentase yang tertera pada tabel berikut ini.

\section{Tabel 5}


Distribusi Frekuensi dan Persentase Hasil Tes Siswa

\begin{tabular}{|c|l|l|l|}
\hline No. & Nilai & Frekuensi & $\begin{array}{l}\text { Persentase } \\
\%\end{array}$ \\
\hline 1. & 80 & 7 & 15.91 \\
\hline 2. & 79 & 4 & 9.13 \\
\hline 3. & 78 & 6 & 13.64 \\
\hline 4. & 75 & 8 & 18.18 \\
\hline 5. & 69 & 6 & 13.64 \\
\hline 6. & 68 & 7 & 15.91 \\
\hline 7. & 67 & 5 & 11.36 \\
\hline 8. & 65 & 1 & 2.23 \\
\hline \multicolumn{2}{|l}{ Jumlah } & 44 siswa & $100 \%$ \\
\hline
\end{tabular}

Berdasarkan tabel diatas diperoleh gambaran tentang frekuensi dan persentase hasil tes siswa Kelas XII SMA Negeri 3 Waeapo, sebagai berikut: nilai tertinggi 80 yang diperoleh 7 siswa atau (15.91\%), nilai 79 diperoleh 4 siswa atau $(9.13 \%)$, nilai 78 diperoleh 6 siswa atau (13.64\%), nilai 75 diperoleh 8 siswa atau $(18.12 \%)$, nilai 69 diperoleh 6 siswa atau $(11.36 \%)$, nilai 68 diperoleh 7 siswa atau (15.91\%), nilai 67 diperoleh 5 siswa atau $(13.64 \%)$, dan nilai 65 diperoleh 1 siswa atau (2.23\%).

Berdasarkan data distribusi frekuensi dan persentase nilai subjek penelitian ditransfer ke dalam konversi angka berskala 10 - 100. Untuk lebih jelasnya, dapat dilihat pada tabel berikut ini.

\section{Tabel 6}

Distribusi Frekuensi dan Persentase Skor

Tes Hasil Kemampuan Menulis Teks

Pidato dengan Menggunakan Bahasa Indonesia yang Baik dan Benar

\begin{tabular}{|l|l|l|l|}
\hline No. & $\begin{array}{l}\text { Rentang } \\
\text { skor }\end{array}$ & Frekuensi & $\begin{array}{l}\text { Persentase } \\
\%\end{array}$ \\
\hline 1. & $10-100$ & 0 & 0 \\
\hline 2. & $67-80$ & 43 & 97,77 \\
\hline 3. & $54-65$ & 1 & 2,23 \\
\hline \multicolumn{2}{|l|}{ Jumlah } & 44 siswa & $100 \%$ \\
\hline
\end{tabular}

Berdasarkan tabel diatas diperoleh gambaran bahwa nilai yang diperoleh siswa sangat bervariasi. Tidak ada siswa yang memeroleh nilai 100, 90, 70, 60, 50, 40, 30, 20 , dan 10. Siswa yang memperoleh nilai $67-80$ berjumlah 43 orang $(97,77 \%)$ dan siswa yang memeroleh nilai 54-65 berjumlah 1 orang $(2,23 \%)$.

Berdasarkan distribusi frekuensi dan persentase tes hasil belajar kemampuan menulis teks pidato dengan menggunakan bahasa Indonesia yang baik dan benar pada siswa Kelas XII SMA Negeri 3 Waeapo, dapat diketahui kategori kemampuan siswa. Untuk lebih jelasnya, dapat dilihat tabel berikut ini.

\section{Tabel 7}

Kategorisasi Tes Tingkat Kemampuan, Frekuensi, dan Persentase

\begin{tabular}{|l|c|l|l|l|}
\hline No. & $\begin{array}{c}\text { Interval } \\
\text { Nilai }\end{array}$ & $\begin{array}{c}\text { Tingkat } \\
\text { Kemampuan }\end{array}$ & $\begin{array}{c}\text { Freku } \\
\text { ensi }\end{array}$ & $\begin{array}{c}\text { Persen } \\
\text { tase }\end{array}$ \\
\hline 1. & $85-100$ & Sangat tinggi & 0 & 0 \\
2. & $67-84$ & Tinggi & 43 & 97,7 \\
3. & $54-66$ & Sedang & 0 & 7 \\
4. & $40-65$ & Rendah & 1 & 0 \\
5. & $0-35$ & Sangat rendah & 0 & 2,23 \\
\hline \multicolumn{2}{|l|}{ Jumlah } & 44 & $100 \%$ \\
& & siswa & \\
\hline
\end{tabular}

Berdasarkan tabel kategorisasi tes tingkat kemampuan, frekuensi, dan persentase tes hasil belajar kemampuan menulis teks pidato dengan menggunakan bahasa Indonesia yang baik dan benar pada siswa Kelas XII SMA Negeri 3 Waeapo menunjukkan bahwa, tidak ada siswa yang berada pada kategori sangat tinggi $(0 \%)$, siswa yang berada pada kategori tinggi diperoleh 43 siswa $(97,77 \%)$, dan tidak ada siswa yang berada pada kategori sedang $(0 \%)$, siswa yang berada pada kategori rendah diperoleh 1 siswa (2.23\%), dan tidak ada siswa yang berada pada kategori sangat rendah $(0 \%)$

Berdasarkan tabel di atas, maka hasil belajar siswa pada kegiatan tes kemampuan menulis teks pidato dengan menggunakan bahasa Indonesia yang baik dan benar berada pada kategori tingi. 
Hasil analisis statistik deskriptif yang berkaitan dengan nilai tes kemampuan menulis teks pidato dengan menggunakan bahasa Indonesia yang baik dan benar pada siswa Kelas XII SMA Negeri 3 Waeapo, diatas dapat dilihat pada tabel berikut ini.

\section{Tabel 8}

Deskripsi Nilai Hasil Tes Siswa Kelas XII

\begin{tabular}{|l|l|}
\hline Statistik & Nilai Statistik \\
\hline Subjek penelitian & 44 \\
Nilai ideal & 100 \\
Nilai tertinggi & 80 \\
Nilai tengah & 68 \\
Nilai terendah & 65 \\
Nilai rata-rata & 73,5 \\
\hline
\end{tabular}

Berdasarkan tabel diatas, dapat digambarkan bahwa dari 44 siswa yang dijadikan subjek penelitian untuk pembelajaran menulis teks pidato dengan menggunakan bahasa Indonesia yang baik dan benar pada siswa Kelas XII SMA Negeri 3 Waeapo, nilai ideal 100, nilai tertinggi yaitu 80 , nilai tengah 68 , nilai terendah 65 , dan nilai rata-rata kelas 73,5 . Penulis dapat menyimpulkan bahwa pada umumnya siswa kelas XII dalam pembelajaran menulis teks pidato dengan menggunakan bahasa Indonesia yang baik dan benar, memiliki tingkat hasil belajar siswa yang cenderung tinggi.

Berdasarkan nilai statistik tes hasil belajar menulis teks pidato dengan menggunakan bahasa Indonesia yang baik dan benar pada siswa Kelas XII SMA Negeri 3 Waeapo, dapat diketahui tingkat kemampuan siswa. Untuk lebih jelasnya dapat dilihat pada diagram di bawah ini.

Diagram Hasil Belajar Menulis Teks Pidato dengan Menggunakan Bahasa Indonesia yang Baik dan Benar Siswa Kelas XII SMA Negeri 3 Waeapo.

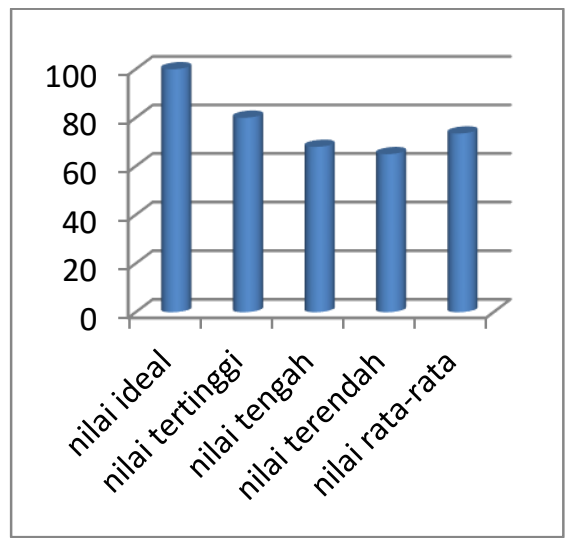

Berdasarkan diagram diatas, dapat digambarkan bahwa dari 44 siswa yang dijadikan subjek penelitian untuk pembelajaran menulis teks pidato dengan menggunakan bahasa Indonesia yang baik dan benar pada siswa Kelas XII SMA Negeri 3 Waeapo, nilai ideal 100, nilai tertinggi yaitu 80 , nilai tengah 68 , nilai rendah 65 , nilai rata-rata 73,5 .

Berdasarkan nilai statistik tes hasil belajar menulis teks pidato dengan menggunakan bahasa Indonesia yang baik dan benar pada siswa Kelas XII SMA Negeri 3 Waeapo dapat diketahui tingkat kemampuan siswa. Untuk lebih jelasnya dapat dilihat pada tabel berikut ini.

Tabel 9

Klasifikasi Tingkat Kemampuan Tes Hasil Belajar Menulis Teks Pidato dengan pada Siswa Kelas XII SMA Negeri 3 Waeapo

\begin{tabular}{|c|c|c|c|}
\hline No. & $\begin{array}{c}\text { Perolehan } \\
\text { nilai }\end{array}$ & Frekuensi & Persentase $(\%)$ \\
\hline 1. & $\begin{array}{c}\text { Nilai } 67- \\
80\end{array}$ & 43 & 97,77 \\
\hline 2. & $\begin{array}{c}\text { Di bawah } \\
67\end{array}$ & 1 & 2.23 \\
\hline & Jumlah & 44 siswa & $100 \%$ \\
\hline
\end{tabular}

Berdasarkan tabel diatas, diketahui bahwa hasil tes belajar menulis teks pidato dengan menggunakan bahasa Indonesia yang baik dan benar pada siswa Kelas XII SMA 
Kemampuan Menulis Teks .... (Nanik Indrayani)

Negeri 3 Waeapo, subjek yang memeroleh nilai $67-80$ berjumlah 43 siswa $(97,77 \%)$ dan subjek yang memeroleh nilai dibawah 67 berjumlah 1 siswa $(2,23 \%)$. Hal ini membuktikan bahwa nilai yang diperoleh siswa Kelas XII SMA Negeri 3 Waeapo, sebesar 67-80 telah mencapai kriteria tingkat kemampuan siswa yaitu diatas 67 .

\section{PENUTUP}

Berdasarkan hasil penelitian belajar menulis teks pidato berbahasa Indonesia di Kelas XII SMA Negeri 3 Waeapo Pulau Buru, peneliti dapat menyimpulkan bahwa siswa mampu menulis teks pidato dengan menggunakan bahasa Indonesia yang baik dan benar.

\section{DAFTAR PUSTAKA}

Arikunto, Suharsimi. 2009. Penelitian Tindakan Kelas. Jakarta:Bumi Aksara.

Daryanto 1997.Kamus Bahasa Indonesia Kontemporer. Keterampilan Berbicara Bahasa Indonesia. Surabaya: Apolo.
Depdiknas. 2001. Pembelajaran Keterampilan Masalah Menulis Paragraf. Jakarta: Erlangga.

Keraf, Gorys. 1984. Tata Bahasa Indonesia untuk Sekolah Lanjutan Atas. Jakarta: Nusa Indah. - 2010. Diksi dan Gaya Bahasa. Jakarta: PT Gramedia Pustaka Utama.

Muslich. 2010. Melaksanakan PTK Itu Mudah. Jakarta: Bumi Aksara.

Natawijaya. 1979. Definisi Menulis. Jakarta: Balai Pustaka.

Suharto.2008. Buku PenelitianBahasa Indonesia. Bandung: Citra Aditya Bakti.

Sujana, Nana. 2004. Pembelajaran Bahasa dan Sastra Indonesia.Jakarta:PT Gramedia Pustaka.

Taha. 2008. Pendidikan dan Transformasi Nilai-Nilai. Jakarta: PTGramedia Pustaka Utama.

Tarigan. 1986. Tujuan Menulis. Jakarta: PTGramedia Pustaka. 



\begin{tabular}{|lcl|}
\hline & TOTOBUANG & \\
\hline Volume 6 & Nomor 1, Juni 2018 & Halaman $109-123$ \\
\hline
\end{tabular}

\title{
HOMONIM BAHASA KEPULAUAN TUKANG BESI DIALEK KALEDUPA DI KABUPATEN WAKATOBI \\ (The Homonymon of Tukang Besi Island languange in Kaledupa Dialect at Wakatobi Regency)
}

\author{
Susiati \\ Universitas Iqra Buru
}

Jl. Prof. Dr. H. A.R. Basalamah No. 20, Namlea, Buru

Pos-el: kaledupa123@gmail.com

(Diterima: 30 April 2018; Direvisi 30 Mei 2018; Disetujui: 3 Juni 2018)

\begin{abstract}
This study aimed to describe the form of word classes that was deeply conformed in the Tukang Besi Island languange, Kaledupa dialect at Wakatobi Regency. This research method was qualitative descriptive method. The data source was taken from the native speakers of Tukang Besi Island language, Kaledupa dialect and it was in oral data. Methods and techniques of data collection were observation methods with participantive observation techniques, recording, and noting techniques. Data analysis techniques were data selection, data classification, meaning, and data analysis. The results proved that the form ofhomonimic word class in Tukang Besi Island languange, Kaledupan dialect were adjectives with nouns, nouns with nouns, verbs with adjectives, verbs with nouns, nouns with numerals, verbs with verbs, verbs with adverbs, particles with nouns.

Keywords: form, homonym, kaledupa language
\end{abstract}

\begin{abstract}
Abstrak
Penelitian ini bertujuan untuk mendeskripsikan wujud kelas kata yang berhomonim dalam Bahasa Kepulauan Tukang Besi Dialek Kaledupa di Kabupaten Wakatobi. Metode yang digunakan adalah metode deskriptif kualitatif. Sumber datanya diambil dari para penutur asli bahasa Kepulauan Tukang Besi Dialek Kaledupa dan jenis datanya berupa data lisan. Metode dan teknik pengumpulan data, yaitu metode observasi dengan teknik observasi partisipatif, teknik rekam, dan teknik catat. Teknik analisis data, yaitu penyeleksian data, pengklasifikasian data, pemaknaan, dan penganalisisan data. Hasil penelitian membuktikan bahwa wujud kelas kata yang berhomonim dalam bahasa Kelupauan Tukang Besi Dialek Kaledupa, yaitu adjektiva dengan nomina, nomina dengan nomina, verba dengan adjektiva, verba dengan nomina, nomina dengan numeralia, verba dengan verba, verba dengan adverbia, dan partikel dengan nomina.
\end{abstract}

Kata-kata Kunci: wujud, homonim, bahasa kaledupa

\section{PENDAHULUAN}

Bahasa digunakan untuk berbagai aktivitas dan kepentingan dalam kehidupan sehari-hari. Begitu pula dengan makna bahasa tersebut terlihat beragam dari segi pandangan yang berbeda-beda. Bahasa sering ditemukan relasi makna. Relasi makna dalam bahasaIndonesia meliputi homonim dan polisemi. Kedua relasi makna ini sangat berkaitan dengan kata atau frasa. Relasi makna artinya hubungan semantik yang terdapat antara satuan bahasa yang satu dengan satuan bahasa yang lainnya. Satuan bahasa dapat berupa kata, frasa maupun kalimat dan relasi semantik itu dapat menyatakan kesamaan makna.
Pertentangan makna, ketercakupan makna, kegandaan makna atau juga kelebihan makna.

Chaer dan Agustina (1995:82) mengungkapkan bahwa dalam relasi makna biasanya dibicarakan sinonim, antonim, homonimi, polisemi, hiponimi, ambiguitas, dan redundansi.

Dalam berkomunikasi sering ditemukan kata-kata yang memiliki tulisan dan pelafalan yang sama tetapi makna dari kata-kata tersebut berbeda. Dalam berkomunikasi bisa saja terjadi kesalahpahaman pada pihak lawan bicara, yang disebabkan oleh kekeliruan si 
pembicara dalam mengungkapkan sesuatu hal yang ingin disampaikan. Untuk menghindari terjadinya kesalahpahaman tersebut, maka dalam berbahasa kita harus mengetahui makna atau arti dari kata tersebut. Fenomena ini biasa disebut dengan homonimi.

Homonimi merupakan salah satu kajian dalam semantik. Aminuddin (2008:124) memaparkan bahwa homonimi ialah beberapa kata yang memiliki bentuk ujaran yang sama, tetapi memiliki makna berbeda-beda. Keraf (2009:36) memberikan definisi singkat bahwa homonimi adalah dua kata atau lebih, tetapi memiliki bentuk yang sama.

Homonimi bukan hanya terdapat dalam bahasa Indonesia, tetapi terdapat pula dalam bahasa Daerah. Sutedi (2003) mengemukakan bahwa setiap bahasa daerah sering ditemukan hubungan antarmakna atau relasi semantik antara sebuah kata atau satuan bahasa lainnya. Semantik memegang peranan penting dalam berkomunikasi karena bahasa memiliki fungsi dan tujuan untuk digunakan dalam berkomunikasi dalam menyampaikan suatu makna. Seperti seseorang yang menyampaikan suatu ide dan pikiran kepada lawan bicara, lalu lawan bicara mampu untuk memahami apayang disampaikan.

Keberagaman bahasa daerah di Indonesia merupakan warisan turun temurun oleh nenek moyang kita. Hal tersebut tercantum dalam Undang-Undang Republik Indonesia Nomor 24 Tahun 2009 pada Bab 1, pasal 1, ayat 6 yang berbunyi "Bahasa daerah adalah bahasa yang digunakan secara turun temurun oleh warga negara Indonesia di daerah-daerah di wilayah Negara Kesatuan Republik Indonesia”. Bahasa daerah perlu dilestarikan. Anjuran ini tertuang dalam Undang-Undang Republik Indonesia Nomor 24 Tahun 2009 pada Bab III, pasal 42, ayat 1 yang berbunyi "Pemerintah daerah wajib mengembangkan, membina, dan melindungi bahasa dan sastra daerah agar tetap memenuhi kedudukan dan fungsinya dalam kehidupan bermasyarakat sesuai dengan perkembangan zaman dan agar tetap menjadi bagian dari kekayaan budaya Indonesia". Oleh karena itu, bahasa daerah dan kekayaan budaya harus dijagadan dikembangkan agar tidak mengalami kepunahan.

Fenomena homonimi terlihat pula dalam bahasa Kepulauan Tukang Besi Dialek Kaledupa. Keberagaman kosakata dalam bahasa Kepulauan Tukang Besi Dialek Kaledupa memperlihatkan fungsinya sehingga memungkinkan setiap orang untuk menyesuaikan dirinya dengan lingkungan fisik dan lingkungan sosial yang memungkinkan setiap orang untuk mempelajari kebiasaan, adat istiadat, kebudayaan serta latar belakang masingmasing. Bahasa Kepulauan Tukang Besiadalah bahasayang digunakan oleh masyarakat di Kabupaten Wakatobi. Kabupaten Wakatobi merupakan akronim dari empat gugus pulau,yaitu Pulau WangiWangi, Pulau Kaledupa, Pulau Tomia, dan Pulau Binongko. Bahasa Kepulauan Tukang Besi merupakan bahasa yang digunakan oleh penduduk asli Wakatobi. Bahasa tersebut merupakan bahasa pertama atau bahasa Ibu. Kedudukan bahasa Wakatobi sangat penting dalam kehidupan masyarakat Wakatobi karena dominan masyarakatnya masih kental menggunakan bahasa Ibu mereka. Penggunaan bahasa Wakatobi selalu dijumpai penggunaannya dalam ranah keluarga, lingkungan masyarakat, maupun lingkungan kerja (sekolah dan kantor).

Suku Wakatobi adalah suatu suku asli yang terdapat di Kabupaten Wakatobi Sulawesi Tenggara. Suku Wakatobi mencapai persentase $90 \%$ dari total jumlah penduduk Kabupaten Wakatobi sebesar 90.000 orang. Suku Wakatobi hampir seluruhnya adalah pemeluk agama Islam.Agama Islam masuk ke dalam kalangan suku Wakatobi diperkirakan sejak beberapa abad yang lalu. Terlihat dengan berdirinya bangunan-bangunan masjid dan musala di desa-desa pemukiman suku Wakatobi.

Bahasa Kepulauan Tukang Besi Dialek Kaledupa memperlihatkan fenomena homonimi, yaitu terdapat kata yang berkelas 
kata verba berhomonimi dengan kata yang berkelas kata nomina, nomina dengan nomina, adjektiva dengan adverbia dan sebagainya.

Salah satu contoh temuan dalam penelitian ini adalah kata verba $h u^{\prime} u$ (beri) berhomonim dengan nomina $h u$ 'u (pohon). Contoh dalam kalimat adalah

a. Uhu'u te ye'e? (kamu beri untuk siapa?)

b. Hu'u nu kau iso no tobangkamo (pohon kayu itu sudah tumbang)

Kedua contoh kalimat di atas terlihat adanya kata yang tulisan dan pelafalannya sama, tetapi maknanya berbeda. Kata $h u$ 'u pada kedua kalimat di atas bersifat dua arah.Kalimat pertama yang ditandai dengan kata $h u$ 'u merupakan kelas kata verba yang bermakna "beri", sedangkan kalimat kedua ditandai pula dengan kata $h u$ 'u merupakan kelas kata nomina yang bermakna "pohon". Kehomoniman suatu kata merupakan hal yang sah. Artinya, kesamaan tulisan dan pelafalan suatu kata adalah hal yang dialami juga oleh bahasa-bahasa lain. Makna suatu kata yang berhomonimi akan terlihat setelah disisipkan dalam suatu kalimat dengan konteks yang berbeda-beda.

Penelitian ini bertumpu pada pengategorian wujud kelas kata yang berhomonimi dalam bahasa Kepulauan Tukang Besi Dialek Kaledupa di Kabupaten Wakatobi.

Sudah banyak literatur khusus tentangbahasa Kaledupa, sehingga dapat menunjang peneliti untuk meneliti topik lain yang berkaitan dengan bahasa Kepulauan Tukang Besi Dialek Kaledupa.Beberapa penelitian yang relevan dengan penelitian ini, yakni Rafiati (2016) "Preposisi Bahasa Kepulauan Tukang BesiDialek Kaledupa"; Wa Ode Salmiani Nur (2015) "TipetipeSemantik Bahasa Kepulauan Tukang Besi Dialek Kaledupa. Nadir La Djamudi (2009) "Deskripsi Fonem Bahasa Keledupa di Kepulauan Tukang Besi Kabupaten Wakatobi" dan "Sistem Reduplikasi Bahasa
Kepulauan Tukang Besi Dialek Kaledupa Kabupaten Wakatobi" (2017).

Berdasarkan uraian di atas, maka fokuspenelitian ini adalah bagaimanakah wujud kelas kata yang berhomonimi dalam bahasa Kepulauan Tukang Besi Dialek Kaledupa Kabupaten Wakatobi? Tujuan penelitian ini bertujuan untuk mendeskripsikan wujud kelas kata yang berhomonimi dalam bahasa Kepulauan Tukang Besi Dialek Kaledupa Kabupaten Wakatobi.

Manfaat yang diharapkan dari hasil penelitian ini adalah sebagai berikut (1) Sebagai sarana pemahaman masyarakat terhadap kata-kata yang berhomonimi di Pulau Kaledupa demi pelestarian dan pemertahanan bahasa daerah Kepulauan Tukang Besi Dialek Kaledupa; (2)Sebagai alat atau media sosialisasi dalam upaya pembinaan dan pengembangan Bahasa Kepulauan Tukang Besi Dialek Kaledupa pada masyarakat Pulau Kaledupa.

\section{LANDASAN TEORI Semantik}

Semantik memegang peranan penting dalam berkomunikasi. Disebabkan bahasa memiliki fungsi dan tujuan untuk digunakan dalam berkomunikasi dalam menyampaikan suatu makna (Sutedi, 2003:2). Seperti seseorang yang menyampaikan suatu ide dan pikiran kepada lawan bicara, lalu lawan bicara mampu untuk memahami apa yang disampaikan.

\section{Relasi Makna}

Relasi makna artinya hubungan semantik yang terdapat antara satuan bahasa yang satu dengan satuan bahasa lainnya.Satuan bahasa dapat berupa kata, frasa, maupun kalimat; dan relasi semantik itu dapat menyatakan kesamaan makna. Relasi makna biasanya dibicarakan antara lain sinonim, antonim, polisemi, homonimi, hiponimi, ambiguiti, dan redundansi (Suparmin, dkk, 2014).

Dalam relasi makna ditemukan dua istilah, yakni homonim dan polisemi. Kedua istilah tersebut sering ditumpahtindihkan 
pengertiannya. Padahal, kedua istilah tersebut sangat berbeda. Untuk itu, pemahaman pengertian dan teori dari homonimi dan polisemi sangat penting. Berikut ini akan dibahas pengertian dan teori homonimi dan polisemi.

\section{Homonimi}

Kata homonimi berasal dari bahasa Yunani yang terdiri dari kataanoma berarti "nama" dan homo berarti "sama".Secara harfiah nama sama untuk benda atau hal lain. Jadi, homonimi adalah dua kata atau lebih yangsama nama, sama bunyi, tetapi berbeda makna.

Suparmin dkk (2014) mengungkapkan bahwa homonimi adalah pertalian dua kata atau lebih yang memiliki makna yang berbeda, tetapi pelafalan dan penulisannya sama. Sama halnya juga dengan Djajasudarma (2009) yang mengatakan bahwa homonimi adalah hubungan makna dan bentuk bila dua buah makna atau lebih dinyatakan dengan sebuah bentuk yang sama.

Wijono (2007) mengungkapkan bahwa homonimi adalah dua kata atau lebih yang sama nama, sama bunyi, sebunyi, tetapi berbeda makna. Di dalam kamus katakata yang termasuk homonimi muncul sebagai lema (entri) yang terpisah. Contoh penulisan kata baku dalam kamus.

${ }^{1}$ ba.ku $n$ pokok (bahan baku)

${ }^{2}$ ba.kuv saling (baku hantam)

\begin{tabular}{|c|c|c|}
\hline Kata & Makna 1 & Makna 2 \\
\hline Baku & $\begin{array}{l}\text { Pokok (bahan } \\
\text { baku) }\end{array}$ & $\begin{array}{l}\text { Saling (baku } \\
\text { hantam) }\end{array}$ \\
\hline
\end{tabular}

Hubungan antara dua kata yang berhomonimi bersifat dua arah. Atinya, jika kata baku yang berarti 'pokok (bahan baku)' berhomonimi dengan kata baku yang berarti 'saling (baku hantam)' juga berhomonimi dengan kata baku yang berarti 'pokok (bahan baku)'. Jika kata baku yang berarti 'pokok (bahan baku)' disebut baku I dan kata baku yang berarti 'saling (baku hantam)' disebut $b a k u$ II, diagramnya sebagai berikut.

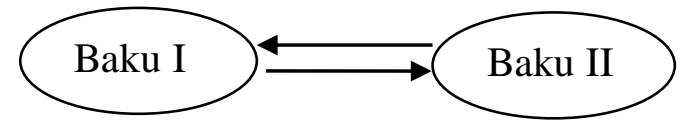

Kata baku pada contoh di atas mempunyai ejaan dan ucapannya yang sama. Akan tetapi, kedua kata tersebut mempunyai makna yang berbeda. Dari contoh tersebut dapat disimpulkan bahwa homonimi adalah dua kata atau frasa yang ejaan atau lafalnya sama, tetapi maknanya berbeda.

Hal tersebut dipertegas pula oleh Suparni (1988) yang menjelaskan bahwa homonimi adalah beberapa kata yang masing-masing mengandung arti sendiri tetapi secara kebetulan sama bentuknya, hanya etimologinya berbeda (sumber berbeda). Secara semantik Verhaar (1978:137) memberikan definisi homonimi sebagai ungkapan (berupa kata, frasa, atau kalimat), tetapi maknanya tidak sama.

Homonimi adalah dua ujaran kata yang sama bunyi dan sama ejaannya, yang telah diketahui berasal dari sumber bahasa yang berbeda atau berbeda bidang makna. Analisis homonimi harus bersifat singkronis, maksudnya bersangkutan dengan peristiwa yang terjadi dalam suatu masa terbatas atau tertentu dan tidak mengakibatkan perkembangan historis atau disebut juga deskriptif.

Di samping itu, ada pula homonimiyang mengenal istilah homofoni (lafal) dan homografi (tulisan), biasanya istilah tersebut dibicarakan bersama karena kesamaan objek pembicaraannya.

Homofoni sebenarnya sama dengan istilah homonimi karena realisasi bentukbentuk bahasa adalah berupa bunyi. Jadi kata 'bisa' yang berarti 'racun ular' dan kata 'bisa' yang berarti 'dapat atau sanggup' selain merupakan bentuk yang homonimi adalah juga bentuk homofoni dan juga homografi karena tulisannya juga sama (Chaer, 1994). Kata-kata yang berhomonimi merupakan kata-kata yang berlainan yang kebetulan saja bentuknya sama. Oleh karena itu, maknanya juga tidak sama. Contohnya kata "buku" yang berarti "kitab" dengan kata "buku" yang berarti "ruas pada bambu 
(tebu), dan juga kata 'buku'yang berarti "tulang atau persendian." Semua itu mempunyai makna yang berbeda-beda, meskipun bentuk dan ucapannya sama.

Untuk dapat mengidentifikasi homonimi dapat dilakukan dengan beberapa cara, yaitu:

1. Pahami etimologi atau asal muasal kata

2. Pahami konteks pemakaian kata/prinsip perluasan kata

3. Pahami makna dasar atau makna inti dari kata. berikut.

Adapun ciri-ciri homonimi sebagai

1. Berupa dua kata atau lebih

2. Tidak ada hubungan makna

3. Digunakan secara denotatif

\section{Jenis-jenis Homonim}

\section{a. Homofon}

Homofon artinya pertalian antara dua kata atau lebih yang sama pengucapannya, tetapi maknanya berbeda.

Contoh:

(1) Bang Ali baru saja menyimpan uangnya di bank.

(2) Hakim menjadi sangsi untuk memberikan sanksi kepada terdakwa.

\section{b. Homograf}

Homograf adalah pertalian antara kata-kata yang memiliki kesamaan tulisan, tetapi berbeda dalam pengucapan dan makna yang terkandung.

Contoh:

(1) Setelah makan buah apel, Arjuna langsung berangkat apel di lapangan.

(2) Pejabat teras itu sedang membaca Koran di teras.

\section{Polisemi}

Dalam kasus ini biasanya makna pertama (yang didaftarkan di dalam kamus) adalah makna sebenarnya, makna leksikalnya, makna denotatifnya, atau makna konseptualnya. Yang lain adalah makna-makna yang dikembangkan berdasarkan salah satu komponen makna yang dimiliki kata atau makna satuan ucap. Polisemi berkaitan dengan kata atau frasa yang memiliki beberapa makna yang berhubungan. Di dalam penyusunan kamus, kata yang berhomonimi muncul sebagai lema (entri) yang terpisah, sedangkan kata yang berpolisemi muncul sebagai satu lema, tetapi dengan beberapa penjelasan.

Contoh kata kepala dapat diartikan bermacam-macam walaupun arti utama kepala adalah bagian tubuh manusia yang ada di atas leher. Contohnya kata kepala dalam Kamus Besar Bahasa Indonesia muncul sebagai satu lema, tetapi dengan beberapa penjelasan seperti berikut.

Ke.pa.la $n^{1}$ bagian tubuh dari leher ke atas seperti pada manusia atau hewan

${ }^{2}$ pimpinan atau ketua

${ }^{3}$ bagian dari sesuatu yang terletak di atas atau depan yang merupakan bagian yang terpenting atau utama

Perhatikan contoh penggunaan kata kepala dalam kalimat.

(1) Kepala sekolah akan memimpin rapat komite

(2) Kepala adik terbentur tembok

(3) Kepala kerta tu sudah tampak tua

Kata kepala pada contoh (1), (2), dan (3) memiliki makna yang berbeda.Pada contoh (1) kata kepala bermakna pimpinan atau ketua. Pada contoh (2) kata kepala bermakna bagian tubuh dari leher ke atas seperti manusia atau hewan. Pada contoh (3) kata kepala bermakna bagian dari sesuatu yang terletak di atas atau depan yang merupakan bagian yang terpenting atau utama.

Polisemi adalah istilah untuk penggunaan dua kata atau lebih yang memiliki bentuk yang sama, tetapi masih memiliki hubungan makna.Polisemi berbeda dengan homonimi, polisemi digunakan secara konotatif (kecuali kata induknya).

Adapun ciri-ciri Polisemi sebagai beikut:

1. Berasal dari satu kata

2. Ada hubungan makna 
3. Digunakan secara konotatif kecuali kata induknya

Aminudin (2008) dalam bukunya 'Semantik' mengambil pendapat Ullman mengenai unsur yang menyebabkan terjadinya polisemi, yaitu (1) spesifikasi dalam ilmu pengetahuan; (2) spesialisasi pemakaian dalam kehidupan sosialmasyarakat yang beraneka ragam;(3) pemakaian dalam gaya bahasa; dan (4) dalam tuturan lisan maupun penulisan yang salah.

\section{Perbedaan Homonimi dan Polisemi}

Perbedaan homonimi dan polisemi terlihat dari pengertian dan ciri-cirinya yang telah diulas sebelumnya. Dua relasi makna tersebut kadang-kadang menimbulkan masalah dalam pemaknaan. Parera (1990) mengatakan bahwa masalah yang muncul dalam relasi makna homonimi dan polisemi adalah kapan dikatakan atau ditentukan dua kata berhubungan secara homonimi dan kapan dua kata itu masuk dalam relasi polisemi.

Perlu diketahui bahwa homonimi dan polisemi tumbuh oleh faktor kesejarahan dan faktor perluasan makna (Djajasudarma, 2009). Jadi keduanya tumbuh sesuai dengan perkembangan masyarakat bahasa itu sendiri. Keduanya memiliki hubungan yang sangat erat karena polisemi dapat saja menjadi penyebab terjadinya homonimi atau sebaliknya homonimi justru menyebabkan adanya polisemi (Aminudin, 2008).

Homonimi ialah dua ujaran dalam bentuk kata yang sama lafalnya dan atau sama ejaannya/tulisannya. Polisemi adalah satu ujaran dalam bentuk kata yang mempunyai makna berbeda-beda, tetapi masih ada hubungan dan kaitan antara makna-makna yang berlainan tersebut (Parera, 1990).

Sebagaimana telah diungkapkan masalah homonimi dan polisemi di atas, adapula masalah yang tengah dihadapi dalam membedakan kedua relasi makna tersebut, yakni bagaimana cara menentukan bahwa satu bentuk ujaran dalam bentuk kata merupakan homonim (jadi seharusnya dua kata) atau merupakan satu kata dengan makna lebih dari satu, tetapi masih berhubungan. Studi tentang hubungan dan perbedaan antara homonimi dan polisemi menuntut studi semantik secara historis (diakronis) dan studi semantik secara sinkronis (Parera, 1990).

Jika dua ujaran kata yang sama bunyinya dan atau sama ejaannya telah diketahui berasal dari sumber bahasa yang berbeda, maka dua kata yang ejaan dan lafalnya sama itu disebut homonimi. Ini berarti jika melakukan satu studi semantik secara historis. Misalnya, kata buku dalam bahasa Indonesia masih dapat dibedakan atas dua sumber asal, maka dapat dikatakan ada homonim: 'buku I' adalah kata Indonesia asli bermakna 'tulang sendi; bagian yang keras pada pertemuan dua ruas' dan 'buku II' yang berasal dari bahasa Belanda yang bermakna 'beberapa helai kertas yang telah terjilid untuk ditulisi atau telah berisi tulisan'.

Palmer (1990) memberikan beberapa kemungkinan jawaban tentang apakah ujaran itu homonimi atau polisemi. kemungkinan-kemungkinan jawaban itu dapat berupa (1) penelusuran etimologi; jika ditemukan ujaran itu berasal dari dua sumber yang berbeda, maka ujaran itu dianggap sebagai homonimi; dalam kamus ujaran itu diperlakukan sebagai dua entri; sedangkan jika tidak ditemukan sumber yang berbeda atau berasal dari satu sumber (walaupun maknanya berbeda), ujaran itu diperlakukan sebagai polisemi; (2) kemungkinan kedua ialah penelitian apakah ujaran dan bentuk kata itu dipergunakan dalam makna harfiahnya dan dalam makna metaforis; dalam hal ini kita akan dapat meramalkan polisemi daripada homonimi; (3) usaha yang ketiga untuk menentukan polisemi atau homonimi ialah mencari sebuah makna inti; memang sulit untuk menentukan makna inti dan makna bukan inti; (4) usaha yang keempat ialah melakukan uji ambiguitas (kedwimaknaan). 


\section{Kelas Kata}

Kridalaksana (1986) menggolongkan kelas kata menjadi tiga belas, yaitu

(1) Verba

Verba merupakan kategori yang dalam tataran frasa dapat dinegatifkan dengan kata tidak dan tidak dapat didampingi kata itu, di, ke, dari, agak, lebih, atau sangat. Verba dibedakan menjadi beberapa bentuk menurut dasar yang berbeda.

(a) Jika dilihat dari bentuknya, verba dibedakan menjadi verba dasar dan verba turunan.

(b) Jika dilihat dari banyaknya pendamping verba, verba dibedakan menjadi verba intransitif dan verba transitif

(c) Jika dilihat dari hubungannya dengan nomina, verba dibagi menjadi verba, aktif, verba pasif, verba antiaktif (ergatif), dan verba antipasif.

(d) Jika dilihat dari interaksi antara nomina dan pendampingnya, verba dibedakan menjadi verba resiprokal dan verba nonresiprokal

(e) Berdasarkan sudut referensi pendamping verba, verba dibagi menjadi verba refleksif dan verba nonrefleksi

(f) Jika dilihat dari sudut pandang hubungan identifikasi antara pendamping verbanya, verba dibedakan menjadi verba kopulatif dan verba ekuatif.

(g) Jika dilihat dari dapat tidaknya dipertentangkan dengan awalan meNdan ber-, verba verba telis dan verba atelis.

\section{(2) Adjektiva}

Adjektiva merupakan kategori yang dapat bergabung dengan kata tidak, dapat didampingi kata lebih, agak, dapat digabung dengan nomina, dapat diubah menjadi nomina jika ditambah dengan imbuhan $k e$ an. Adjektiva jika dilihat dari bentuknya dibagi menjadi adjektiva dasar, adjektiva turunan, dan adjektiva paduan leksem.
Nomina merupakan kategori yang secara sintaksis tidak dapat bergabung dengan kata tidak dan dapat didahului kata dari. Nomina berdasarkan bentuknya dibagi menjadi nomina dasar, nomina turunan, nomina paduan leksem, dan nomina paduan leksem gabungan.

\section{(4)Pronomina}

Pronomina merupakan kategori yang berfungsi untuk menggantikan nomina.Kata yang digantikan oleh pronomina disebut anteseden.

\section{(5) Numeralia}

Numeralia adalah kategori yang dapat mendampingi nomina dalam konteks sintaksis, dapat mendampingi numeralia yang lain, dan tidak dapat bergabung dengan kata tidak dan sangat. Numeralia digunakan untuk mewakili bilangan yang terdapat dalam alam di luar bahasa.

\section{(6) Adverbia}

Adverbia merupakan kategori yang dapat mendampingi adjektiva, numeralia, atau preposisi dalam kontruksi sintaksis. Adverbial dapat berupa bentuk dasar atau turunan.Bentuk turunan adverbia dibentuk dari afiksasi, reduplikasi, gabungan proses, dan gabungan morfem.

\section{(7)Interogativa}

Interogativa adalah kategori dalam kalimat interogatif yang berfungsi menggantikan sesuatu yang ingin diketahui atau ditanyakan oleh pembicara. Interogativa menurut bentuknya dibagi menjadi interogativa dasar dan interogativa turunan.

\section{(8)Demonstrativa}

Demonstrativa merupakan kategori yang berfungsi menunjukkan sesuatu di dalam maupun di luar wacana. Menurut bentuknya demonstrativa dibedakan menjadi demonstrativa dasar dan demonstrativa turunan.

(9) Artikula 
Artikula merupakan kategori yang mendampingi nomina dasar.Artikula merupakan partikel sehingga tidak berartikulasi.

\section{(10) Preposisi}

Preposisi merupakan kategori yang terletak di depan kategori lain sehingga terbentuk frasa eksosentris direktif. Preposisi dibagi menjadi tiga, yaitu preposisi dasar, preposisi turunan, dan preposisi yang berasal dari kategori lain.

(11) Konjungsi

Konjungsi merupakan kategori yang berfungsi untuk memperluas satuan lain dalam konstruksi hipotaksis dan menggabungkan satuan lain.

\section{(12) Kategori fatis}

Kategori fatis merupakan kategori yang bertugas memulai, mempertahankan, atau mengukuhkan pembicaraan antara pembicara dan lawan bicara.

\section{(13) Interjeksi}

Interjeksi merupakan kategori yang berfungsi mengungkapkan perasaan pembicara dan secara sintaksis tidak berhubungan dengan kata-kata lain dalam ujaran.

\section{METODE PENELITIAN \\ Pendekatan dan Jenis Penelitian}

Penelitian ini merupakan jenis penelitian deskriptif kualitatif dengan menggunakan pendekatan semantik. Penelitian kualitatif dengan metode deskriptif adalah penelitian yang mengidentifikasi, mengklarifikasi, menganalisis data yang telah diperoleh, dan pendeskripsiannya berupa penggambaran bahasa sebagaimana adanya (Sudaryanto, 1993). Dengan demikian, pendeskripsian data penelitian ini berupa leksikon dari bahasa Kepulauan Tukang Besi Dialek Kaledupa yang berpotensi berhomonimi. Pendekatan semantik digunakan untuk menjelaskan hubungan antarmakna dalam tiap leksikon.

\section{Sumber Data dan Jenis Data}

Sumber data penelitian ini adalah penutur asli, yakni masyarakat Kaledupa. Jenis data adalah data lisan yang diperoleh dari tuturan penutur asli bahasa Kepulauan Tukang Besi Dialek Kaledupa.

\section{Metode dan Teknik Pengumpulan Data}

Metode dalam penelitian ini adalah metode observasi. Teknik-teknik yang digunakan untuk melengkapi metode observasi tersebut antara lain. (a) teknik observasi partisipasi (participant to bservation), yaitu teknik pengumpulan data yang digunakan untuk menghimpun data penelitian melalui pengamatan dan penginderaan, peneliti benar-benar terlibat dalam keseharian responden. Sibarani (2004) metode observasi partisipasi, yakni ikut berpartisipasi dalam kegiatan yang diobservasi, dideskripsi, dan dianalisis. Stainback (dalam Sugiyono, 2010) dalam observasi partisipasi, peneliti mengamati segala kegiatan yang dikerjakan responden, mendengarkan yang mereka ucapkan, dan berpartisipasi dalam aktivitas mereka; (b) teknik rekam, yakni digunakan untuk merekam peristiwa-peristiwa yang secara potensial banyak menggunakan tuturan emosi; dan (c) teknik catat, dari hasil rekaman, data-data berupa tuturan yang diucapkan responden dicatat, selanjutnya diseleksi dan diidentifikasi.

\section{Teknik Analisis Data}

Penerapan langkah-langkah dalam teknik analisis data sebagai berikut

\section{Penyeleksian data}

Kata yang berelasi makna dalam bahasa Kepulauan Tukang Besi yang telah diperoleh dari teknik pengumpulan data diseleksi yang termasuk kata-kata yang berhomonimi dengan menggunakan teori Palmer. 
2. Pengklasifikasian dan pemaknaan data

Penggolongan data hasil seleksi diklasifikasidan melalui proses pemaknaan berdasarkan pada fokus masalah, yakni wujud kelas kata yang berhomonimi dalam bahasa Kepulauan Tukang Besi Dialek Kaledupa(teori pembagian kelas kata Kridalaksana).

Penelitian ini menggunakan beberapa instrumen, seperti catatan lapangan, alat rekam, kartu data, tabel klasifikasi, dan lembar observasi. Sementara itu, tabel klasifikasi digunakan untuk mempermudah analisis wujud kelas kata yang berhomonimi dalam bahasa Kepulauan Tukang Besi Dialek Kaledupa. Adapun tabel yang dimaksud adalah

\begin{tabular}{|l|l|l|l|l|}
\hline \multirow{2}{*}{ Data } & \multirow{2}{*}{ M1 } & \multirow{2}{*}{ M2 } & \multicolumn{2}{|c|}{ Kelas Kata } \\
\cline { 4 - 5 } & & & M1 & M2 \\
\hline & & & & \\
\hline
\end{tabular}

Catatan: M1: Makna 1 (pertama)

M2: Makna 2 (kedua)

3. Penganalisisan data

Data yang telah diklasifikasi, kemudian dianalisis dengan mendeskripsikan secara mendetail permasalahan yang terdapat dalam data yang telah dikumpulkan berdasarkan teori wujud kelas kata yang berhomonimi dalam bahasa
Kepulauan Tukang Besi Dialek Kaledupa, sebagai dasar pedoman dalam menganalisis.

\section{PEMBAHASAN}

Hasil penelitian, ditemukanwujudkelas katayang berhomonim dalam bahasa Kepulauan Tukang BesiDialek Kaledupa. Adapun bentuk kelas kata yang berhominim tersebut adalah.

\begin{tabular}{|c|l|l|}
\hline \multirow{2}{*}{ No. } & \multicolumn{2}{|c|}{ Kelas Kata } \\
\cline { 2 - 3 } & Kelas Kata 1 & \multicolumn{1}{|c|}{ Kelas Kata 2 } \\
\hline 1. & Adjektiva & Nomina \\
\hline 2. & Nomina & Nomina \\
\hline 3. & Verba & Adjektiva \\
\hline 4. & Verba & Nomina \\
\hline 5. & Nomina & Numeralia \\
\hline 6. & Verba & Verba \\
\hline 7. & Verba & Adverbia \\
\hline 8. & Partikel & Nomina \\
\hline
\end{tabular}

Untuk lebih jelasnya perhatikan penjelasan tiap kelas kata yang berhomonimi dalam bahasa Kepulauan Tukang Besi Dialek Kaledupa.

\section{a. Adjektiva Nomina}

Fenomena homonimi dalam bahasa Kepulauan Tukang Besi Dialek Kaledupa terlihat pada kata yang berkelas kata adjektiva yang berhomonim dengan kelas kata nomina.Perhatikan contoh data berikut.

\begin{tabular}{|l|l|l|l|l|}
\hline \multirow{2}{*}{ Data } & \multicolumn{1}{|c|}{ M 1 } & \multicolumn{1}{c|}{ M 2 } & \multicolumn{2}{c|}{ Kelas Kata } \\
\cline { 4 - 5 } & & & M 1 & M 2 \\
\hline Modo & Sebentar & Air laut pasang & Adjektiva & Nomina \\
\hline Songko & Ketat & Kopiah & Adjektiva & Nomina \\
\hline Nihi & Tipis & Mimpi & Adjektiva & Nomina \\
\hline
\end{tabular}

\section{Contoh 1}

(a) Modo, baraho to inte kua daoa anneho no modo

(Sebentar, jangan dulu kita pergi ke pasar karena air laut masih pasang)

(b) Te songko iso no songko ara ako tei ko'o
(Kopiah itu pasti sempit kalau untuk kamu)

(c) di nihi kuita te orunguú nihikadu, u sodo?

(dalam mimpiku saya melihatmu badanmu tipis setipis karung, kamu sakit?)

Tiga contoh di atas, terlihat adanya tiga kata yang mempunyai homoniminya 
masing-masing, yaitu modo, songko, dan nihi. Ketiga kata tersebut tergolong berhomonimi karena tiap kata itu mempunyai pertalian dua kata yang memiliki pelafalan dan penulisan yang sama, tetapi makna berbeda. Dilihat pula dari wujud kelas kata ketiga kata tersebut (modo, songko, dan nihi), dibentuk oleh kelas kata adjektiva dan kelas kata nomina.

Contoh 1 (a) terdapat dua kata modo yang digunakan dalam kalimat yang sama. Kata modo mempunyai dua arti atau makna, yakni sebentar (adjektiva) dan air laut yang pasang (nomina). Perlu diketahui bahwa dalam bahasa Kepulauan Tukang Besi terdapat bunyi huruf implosif, yakni bunyi huruf $a$ (Dosa 'utang') dan 5 (bosu 'gusi'). Bunyi implosif adalah hentian yang terjadi dengan aliran udara diisap oleh glotis. Terlihat pula pada contoh 1 (b), yakni kata songko yang memiliki dua makna, yakni kata songko I bermakna ketat (adjektiva) dan kata songko II bermakna kopiah (nomina). Hal yang sama tampak juga pada contoh 1 (c) kata yang berhomonim, yaitu kata nihi. Kata nihi mempunyai dua makna, yakni kata nihi I bermakna tipis (adjektiva) dan kata nihi II bermakna mimpi (nomina). Ketiga contoh kata di atas (modo, songko, dan nihi) masing-masing mempunyai hubungan yang bersifat dua arah. Artinya, jika kata modo yang bermakna 'sebentar' berhomonimi dengan kata modo yang bermakna 'air laut pasang', maka kata modo yang bermakna 'air laut pasang' juga berhomonimi dengan kata modo yang bermakna 'sebentar'. Jika kata modo yang bermakna 'sebentar' disebut modo I dan kata modo yang bermakna 'air laut pasang' disebut modo II, diagramnya sebagai berikut.

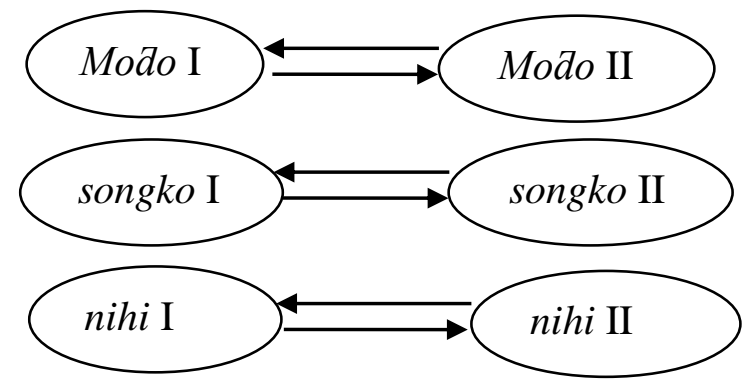

\section{b. Nomina Berhomonimi dengan Nomina}

Fenomena homonimi dalam bahasa Kepulauan Tukang Besi Dialek Kaledupa terlihat pada kata yang berkelas kata nomina yang berhomonim dengan kelas kata nomina. Perhatikan contoh data berikut.

\begin{tabular}{|l|l|l|c|c|c|c|}
\hline Data & \multicolumn{1}{|c|}{ M 1 } & M 2 & \multicolumn{2}{|c|}{ M 3 } & \multicolumn{3}{|c|}{ Kelas Kata } \\
\cline { 5 - 7 } & $\begin{array}{l}\text { Kelapa } \\
\text { yang } \\
\text { sudah tua }\end{array}$ & Mampus & - & M 1 & M 2 & M 3 \\
\hline Temba & Senapan & $\begin{array}{l}\text { Teras } \\
\text { rumah }\end{array}$ & - & Nomina & Nomina & Nomina \\
\hline Eoka & Sisa & $\begin{array}{l}\text { Telur } \\
\text { busuk }\end{array}$ & $\begin{array}{l}\text { Seserahan dari } \\
\text { seorang lelaki kepada } \\
\text { calon istrinya (berupa } \\
\text { ayam atau makanan) }\end{array}$ & Nomina & Nomina & Nomina \\
\hline
\end{tabular}

\section{Contoh 2}

(a) Ifa di atué, bara bo'ua norahokko te poso atué maka uposo (pindah di situ nanti kamu dijatuhi sama kelapa tua itu, kamu mampus itu)

(b) Intealaé na temba di temba

(pergi ambil senapan di teras) 
(c) Ragamo tegoraú boka na no boka kita

(tinggal telur busuk yang dia sisakan kita)

Contoh 2 (a) terdapat dua kata poso yang digunakan dalam kalimat yang sama. Kata poso mempunyai dua makna, yakni poso I yang bermakna kelapa yang sudah tua (nomina) dan poso II yang bermakna mampus (nomina), termasuk homonimi karena antara kata poso I dan kata poso II tidak memiliki hubungan makna.Terlihat pula pada contoh 2 (b), yakni kata temba yang memiliki dua makna, yakni temba I yang bermakna senapan (nomina) dan temba II yang berarti teras rumah (nomina). Kata temba termasuk homonimi karena antara temba I dan temba II tidak mempunyai hubungan makna. Hal yang sama tampak juga pada contoh 2 (c) kata yang berhomonimi, yaitu kata boka. Kata 5oka mempunyai tiga makna, yakni boka I yang bermakna sisa (nomina), boka II yang bermakna telur busuk (nomina), dan Eoka III yang berarti seserahan seorang lelaki kepada calon istrinya yang bisa berupa ayam atau makanan (nomina). Kata boka termasuk homonimi karena antara kata boka I, boka I, dan boka III tidak memiliki hubungan makna.

\section{c. Verba Berhomonimi dengan Adjektiva}

Homonimi dalam bahasa Kepulauan Tukang Besi Dialek Kaledupa terlihat pula pada kata yang berkelas kata verba yang berhomonimi dengan kelas kata adjektiva. Perhatikan contoh data berikut.

\section{Contoh 3}

\begin{tabular}{|l|l|l|l|l|}
\hline Data & \multicolumn{1}{|c|}{ M 1 } & \multicolumn{1}{c|}{ M 2 } & \multicolumn{2}{|c|}{ Kelas Kata } \\
\cline { 4 - 5 } & & & M 1 & M 2 \\
\hline Buri & Tulis & Warna belang & Verba & Adjektiva \\
\hline Pake & Pakai & Sikap/karakter & Verba & Adjektiva \\
\hline
\end{tabular}

(a) Anne kuburi di kapeo, nomai na mia mosafu tekadole kene kadola buri mia atu'e

(saya masih menulis kemarin, datang orang yang menyabung ayam dengan ayam belang-belang itu)

(b) Pake'e na pake leama kua mia (pakailah sikap yang baik kepada orang lain)

Contoh 3 (a) terdapat dua kata buriyang digunakan dalam kalimat yang sama. Kata buri mempunyai dua makna, yakni kata buri I bermakna tulisyang berkelas kata verba dan kata buri II yang bermakna warna belang-belang yang berkelas kata adjektiva. Kata buripada contoh kalimat di atas termasuk homonimi karena antara kata buri I dan buri II tidak memiliki hubungan makna. Pada contoh 3 (b), yakni kata pake yang memiliki dua makna, yakni kata pake I bermakna pakai yang berkelas kata verbadan kata pake II bermakna sikap/karakter yang berkelas kata adjektiva. Kata pake termasuk homonimi karena antara kata pake I dan kata pake II tidak memiliki hubungan makna.

\section{d. Verba Berhomonimi dengan Nomina}

Homonim dalam bahasa Kepulauan Tukang Besi Dialek Kaledupa terlihat pula pada kata yang berkelas kata verba yang berhomonimi dengan kelas kata nomina. Perhatikan contoh data berikut.

\section{Contoh 4}

\begin{tabular}{|c|c|c|c|c|}
\hline \multirow[t]{2}{*}{ Data } & \multirow[t]{2}{*}{ M1 } & \multirow[t]{2}{*}{ M 2} & \multicolumn{2}{|c|}{ Kelas Kata } \\
\hline & & & M 1 & M2 \\
\hline Нии́ & Beri & Pohon & Verba & Nomina \\
\hline Koho & Potong & Burung bangau & Verba & Nomina \\
\hline Tотра & Loncat/lompat & Teras rumah & Verba & Nomina \\
\hline
\end{tabular}


(beri untuk tetangga pohon itu)

(b) Koho'e na koho di singku afo (potongkan burung bangau yang ada di dapur sana)

(c) Te aeno no toppuge kaliu no tompa mina tompa nu sapono

(kakinya patah karena dia lompat dari teras rumahnya)

Contoh 4 (a) terdapat dua kata huú yang digunakan dalam kalimat yang sama. Kata huú mempunyai dua makna, yakni kata huú I beri (verba)dankata huú II bermakna bermakna pohon (nomina).Kata huú termasuk homonimi karena antara kata huú I dan kata hии́ II tidak memiliki hubungan makna. Terlihat pula pada contoh 4 (b), yakni kata koho yang memiliki dua makna, yakni kata koho I bermakna potong (verba) dankata koho II bermakna burung bangau
(nomina).Kata koho termasuk homonimi karena antara kata koho I dan kata koho II tidak memiliki hubungan makna. Hal yang sama tampak juga pada contoh 4 (c) kata yang berhomonimi, yaitu kata tompa. Kata tompamempunyai dua makna, yakni kata tompa I bermakna lompat/loncat (verba) dan kata tompa II bermakna teras rumah (nomina). Kata tompa termasuk homonimi karena antara kata tompaI dan kata tompaII tidak memiliki hubungan makna.

\section{e. Nomina Berhomonimi dengan Numeralia}

Homonimi dalam bahasa Kepulauan Tukang Besi Dialek Kaledupa terlihat pula pada kata yang berkelas kata nomina yang berhomonimi dengan kelas kata numeralia. Perhatikan contoh data berikut.

\section{Contoh 5}

\begin{tabular}{|l|l|l|l|l|}
\hline Data & \multirow{2}{*}{ M 1 } & \multicolumn{1}{c|}{ M 2 } & \multicolumn{2}{c|}{ Kelas Kata } \\
\cline { 4 - 5 } & & & M 1 & M 2 \\
\hline Lima & Tangan & Angka lima & Nomina & Numeralia \\
\hline dua & Penjolok & Angka dua & Nomina & Numeralia \\
\hline Sia & Lerai & Angka sembilan & Nomina & Numeralia \\
\hline
\end{tabular}

(a) di limaú mo na kenta lima kau di iso?

(sudah kamu pegang ikan lima ekor di sana?)

(b) Ku'ada te đua anaé, kudumua te lemo dodua iso

(saya pinjam penjolok ini, saya mau jolok dua buah lemon sana)

(c) No siate yeé, na mia sia mia atu baái?

(mereka lerai siapa, sembilan orang tadi?)

Contoh 5 (a) terdapat dua kata lima yang digunakan dalam kalimat yang sama. Kata lima mempunyai dua makna, yakni kata lima I bermakna tangan (nomina)dan kata lima II bermakna angka lima (numeralia). Terlihat pula pada contoh 5 (b), yakni kata $a u a$ yang memiliki dua makna, yaitu kata dua I bermakna penjolok (nomina) dankata dua II bermakna angka dua (numeralia). Hal yang sama tampak juga pada contoh 5 (c) kata yang berhomonimi, yaitu kata sia. Kata sia mempunyai dua makna, yakni kata siaI bermakna lerai (nomina) dan kata siaII bermakna angka sembilan (numeralia).

\section{f. Verba Berhomonimidengan Verba}

Fenomena homonimi dalam bahasa Kepulauan Tukang BesiDialek Kaledupa terlihat pada kata yang berkelas kata verba yang berhomonimi dengan kelas kata verba. Perhatikan contoh data berikut.

\begin{tabular}{|l|l|l|l|l|}
\hline Data & \multicolumn{1}{|c|}{ M 1 } & \multicolumn{1}{c|}{ M 2 } & \multicolumn{2}{c|}{ Kelas Kata } \\
\cline { 4 - 5 } & & & M 1 & \multicolumn{1}{c|}{ M 2 } \\
\hline Ita & Jaga & Lihat & Verba & Verba \\
\hline Langke & Berangkat & $\begin{array}{l}\text { Menurunkan } \\
\text { panci dari }\end{array}$ & Verba & Verba \\
\hline
\end{tabular}


ita I bermakna lihat (verba) dan kata ita I bermakna jaga (verba). Kata ita termasuk homonimi karena antara kata ita I dan kata ita II tidak memiliki hubungan makna. Terlihat pula pada contoh 5 (b), yakni kata langke yang memiliki dua makna, yakni kata langke I bermakna berangkat (verba) dan

\section{Contoh 6}

(a) U ita'e namia u mitate kenta di ana baái?

(kamu lihat orang yang jaga ikan di sini tadi?)

(b) Ara boua kulangke ilange, langke'e na kekeru mina di dalika.

(kalau saya berangkat besok, turunkan panci dari tungku)

Contoh 6 (a) terdapat dua kata ita yang digunakan dalam kalimat yang sama. Kata ita mempunyai dua makna, yakni kata

\section{Contoh 7}

\begin{tabular}{|l|l|l|c|c|}
\hline Data & M 1 & \multicolumn{1}{|c|}{ M 2 } & \multicolumn{2}{|c|}{ Kelas Kata } \\
\cline { 4 - 5 } & & & M 1 & M 2 \\
\hline Pisi & Pencet/tekan & Sangat & Verba & adverbia \\
\hline
\end{tabular}

(a) Pisié mempisi na tombolno atué (pencet dengan keras tombolnya itu)

Contoh 7 (a) terdapat dua kata pisiyang digunakan dalam kalimat yang sama. Kata pisi mempunyai dua makna, yakni kata pisi I bermana pencet/tekan (verba) dan kata pisi II bermakna sangat (adverbia). Kata pisi termasuk homonimi karena antara kata pisi I dan kata pisi II tidak memiliki hubungan makna.

\section{h. Patikel Berhomonimidengan Nomina}

Dalam bahasa Kepulauan Tukang Besi Dialek Kaledupa fenomena homonimi terlihat pula pada kata yang berkelas kata partikel yang berhomonimi dengan kelas kata nomina. Perhatikan contoh data berikut.

\section{Contoh 8}

\begin{tabular}{|l|l|l|l|l|}
\hline Data & \multicolumn{1}{|c|}{ M 1 } & \multicolumn{1}{c|}{ M 2 } & \multicolumn{2}{c|}{ Kelas Kata } \\
\cline { 4 - 5 } & & & \multicolumn{1}{c|}{ M 1 } & M 2 \\
\hline Kene & Dengan & Teman & Partikel & Nomina \\
\hline Ara & Kalau & Arak & Partikel & Nomina \\
\hline Mia & Yang & Orang & Partikel & Nomina \\
\hline
\end{tabular}

(a) di nggafi kufila-fila kenekene. (kemarin saya jalan-jalan dengan teman)

(b) Ara di iso anne na ara?

(kalau di sana ada minuman arak?)

(c) Sai leama mia nosannaa na mia (bersikap baik yang membuat orang senang)

Contoh 8 (a) terdapat dua kata kene yang digunakan dalam kalimat yang sama. Kata kene mempunyai dua makna, yakni kata kene I bermakna dengan 
(partikel)dankata kene I bermakna teman (nomina).Kata kene termasuk homonimi karena antara kata kene I dan kata kene II tidak memiliki hubungan makna.Terlihat pula pada contoh 8 (b), yakni kata ara yang memiliki dua pertalian makna, yakni kata ara I bermakna kalau (partikel) dankata ara II bermakna arak (nomina). Kata ara termasuk homonimi karena antara kata araI dan kata ara II tidak memiliki hubungan makna. Hal yang sama tampak juga pada contoh 8 (c) kata yang berhomonimi, yaitu kata mia. Kata mia mempunyai dua makna, yakni kata mia I bermakna yang (partikel) dan kata mia II bermakna orang (nomina). Kata mia termasuk homonimi karena antara kata mia I dan kata mia II tidak memiliki hubungan makna.

\section{PENUTUP}

Berdasarkan hasil penelitian pada pembahasan, penulis dapat menarik kesimpulan sesuai dengan tujuan penelitian, yaitu wujud kelas kata yang berhomonimi dalam bahasa Kepulauan Tukang Besi Dialek Kaledupa terdapat delapan kelas kata yang saling berhomonimi antara lain:

1. Terdapat kelas kata adjektiva yang berhomonimi dengan kelas kata nomina.

2. Kelas kata nomina yang berhomonimi dengan kelas kata nomina.

3. Kelas kata verba berhomonimi dengan kelas kata adjektiva.

4. Kelas kata verba berhomonimi dengan kelas kata nomina.

5. Kelas kata nomina berhomonimi dengan kelas kata numeralia.

6. Kelas kata verba berhomonimi dengan kelas kata verba.

7. Kelas kata verba berhomonimi dengan kelas kata adverbia.

8. Partikel berhomonimi dengan kelas kata nomina.

\section{DATAR PUSTAKA}

Aminuddin. 2008. Semantik: Pengantar Studi Tentang Makna. Bandung: Sinar Baru Algesindo.
Chaer, Abdul. 1997. Semantik Bahasa Indonesia. Jakarta: Depdikbud.

Chaer, Abdul dan Leonie Agustina.1995. Sosiolinguistik Perkenalan Awal. Jakarta: Rineka Cipta.

Djajasudarma, Fatimah. 2009. Semantik 1: Makna Leksikal dan Gramatikal. Bandung: Refika Aditama.

Djamudi, Nadir La. 2009."Deskripsi Fonem

Bahasa Kaledupa di

KepulauanTukang Besi

Kabupaten Wakatobi" Jurnal Kandai, Vol.5 No. 2 November 2009, ISSN 1907-204X) 2017.“Sistem Reduplikasi Bahasa KepulauanTukang Besi Dialek Kaledupa Kabupaten Wakatobi” Jurnal Totobuang, Vol.5 No 1Juni 2017)

Keraf, Gorys. 2009. Diksi dan Gaya Bahasa. Jakarta: PT Gramedia Pustaka Utama.

Kridalaksana, Harimurti. 1986. Beberapa Prinsip Perpaduan Leksem. Yogyakarta: Kanisius.

Kridalaksana, Harimurti. 2001. Kelas Kata dalam Bahasa Indonesia. Jakarta: Gramedia.

Lyons, John. 1968. Introduction to Theoritical Linguistics. Cambridge: The University Printing House.

Nur, Wa Ode Salmiani. 2015. "TipeTipeSemantik Bahasa Kepulauan Tukang Besi Dialek Kaledupa". Jurnal Humanika. No. 15 Vol. 3 Desember2015.ISSN 1979-8296.

Palmer, F.R. 1981. Semantics.Cambridge: University Press.

Parera, J.D. 1990. Teori Semantik. Jakarta: Erlangga.

Rafiati. 2016. "Preposisi Bahasa Kepulauan Tukang Besi Dialek Kaledupa". Jurnal Humanika. No. 16 Vol. 1 Maret 2016.ISSN 1979-8296.

Sibarani, Robert. 2004. Antropolinguistik: Antropologi Linguistik, Linguistik Antropologi. Medan: Poda.

Sudaryanto.(1993). Metode dan Aneka Teknik Analisis Bahasa. 
Homonim Bahasa Kepualauan .... (Susiati)

Yogyakarta: Duta Wacana

University Press.

Sugiyono.(2010). Metode Penelitian

Kuantitatif Kualitatif dan RND. Bandung: Alfabeta.

Suparmin, dkk. 2014. Bahasa dan Sastra

Indonesia Peminatan Ilmu

Bahasa dan Budaya. Surakarta: Mediatama.
Suparni.1988. Penuntun Pelajaran Bahasa dan Sastra Indonesia. Bandung: Genica.

Sutedi,Dedi. 2003. Dasar-dasar Linguistik Bahasa Jepang. Bandug: Humaniora Utama Press.

Verhaar, J.W.M. 1978. Pengantar LinguisticJilid I. Yogyakarta. Gadjah Mada Universiti Press. 



\begin{tabular}{|lll|}
\hline \multicolumn{3}{|c|}{ TOTOBUANG } \\
\hline Volume 6 & Nomor 1, Juni 2018 & Halaman 125-138 \\
\hline
\end{tabular}

\title{
TUTURAN EMOSI MAHASISWA KOTA BAUBAU DALAM RANAH DEMONSTRASI
}

(Emotional Speech of The Students in Baubau City in The Demonstration)

\author{
Risman Iye \\ Universitas Iqra Buru \\ Jl. Prof. Dr. H. A.R. Basalamah No. 20, Namlea-Kab. Buru \\ Pos-el: rismaniye@gmail.com
}

(Diterima: 25 April 2018; Direvisi: 13 Mei 2018 Mei 2018; Disetujui: 5 Juni 2018)

\begin{abstract}
The variation of emotional utterances of the demonstrators rose the negative public attachments to the demonstration. This study aimed to explain: the form and type of emotional speech of Baubau City students in the realdemonstration. This research wa qualitative research. The Sampling were taken purposively. Oral data was collected by using the free-of-cognate method, documentation techniques, and notes. Data were analyzed with Searle's speech-actg theory and Goleman's theory. The result of the research showed that the form and type of emotional speech of Baubau city students in demonstration were four: words, phrases, sentences and idoms. Meanwhile, the types of emotional speech of Baubau City students in demonstration were anger, sadness, fearlessness, pleasure, and annoyance.
\end{abstract}

Keywords: emotions, students, demontsration.

\begin{abstract}
Abstrak
Variasi tuturan emosi para demonstran memunculkan prasangka negatif masyarakat terhadap demonstrasi tersebut. Penelitian ini bertujuan untuk menjelaskan: bentuk dan jenis tuturan emosi mahasiswa Kota Baubau dalam ranah demonstrasi; Penelitian ini merupakan jenis penelitian kualitatif. Pengambilan sampel dilakukan secara purposif. Data lisan dikumpullkan menggunakan metode simak bebas cakap, teknik dokumentasi, dan catat. Data dianalisis dengan teori tindak tutur Searle dan teori Goleman. Hasil penelitian menunjukan bahwa bentuk tuturan emosi mahasiswa kota Baubau dalam ranah demonstrasi ada empat, yaitu kata, frasa, kalimat dan ungkapan Selanjutnya, jenis tuturan emosi mahasiswa Kota Baubau dalam ranah demonstrasi, yakni kemarahan, kesedihan, ketakutan, kenikmatan, dan kejengkelan.
\end{abstract}

Kata-kata Kunci: tuturan emosi, mahasiswa, demostrasi

\section{PENDAHULUAN}

Bahasa yang dihasilkan oleh seseorang akan selalu menjadi cerminan pribadi, derajat sikap, watak atau karakter mental spiritualnya. Oleh karena itu, bahasa dipandang sebagai identitas yang nyata bagi penutur-penuturnya. Kata atau bahasa yang digunakan oleh seseorang dalam berturtur disebut dengan istilah pragmatik. Levinson dalam Tarigan (1990), bahasa mempunyai peranan penting dalam kehidupan manusia. Selain sebagai media komunikasi, bahasa juga dapat digunakan seseorang untuk mengekspresikan dirinya dan segala hal yang dirasakan untuk diungkapkan kepada orang lain. Menurut Chaer (2012), dengan bahasa memungkinkan tiap orang untuk mempelajari kebiasaan, adat istiadat, kebudayaan, serta latar belakang antarpeserta komunikasi masing-masing. Melalui bahasa pula, seseorang dapat mengungkapkan emosinya, baik emosi positif maupun emosi negatif. Salah satu hal yang berhubungan dengan pengungkapan emosi negatif, yaitu makian.

Kata-kata makian sering ditemukan dalam demontrasi karena mahasiwa cenderung menggunakan bahasa yang kasar dan tidak ditutup-tutupi. Salah satu bentuk pemakaian tuturan emosi ini banyak ditemukan di Kota Baubau.Misalnya tuturan para demonstran, yaitu selamat malamKota Baubau.Kata ini apabila diucapkan saat malam hari tentu tidak dikatakan sebagai emosi karena diucapkan sesuai dengan 
keadaan sebenarnya namun apabila kata tersebut diucapkan siang hari dengan mimik merah dan suara lantang tentu memiliki makna lain bahkan bisa dikatakan sebagai emosi. Contoh lain juga pada kata bantingarti kata banting pada bidangnya tentu terasa biasa. Kalau orang sedang membicarakan soal-soal ekonomi, tentu artinya adalah memurahkan harga, dan apabila diucapkan oleh pemain judo tentulah banting berarti mengangkat seseorang dan menjatuhkan dengan cepat. Jadi dapat dikatakan bahwa dalam ilmu prgmatik pemakain bahasa terikat dengan konteks.

Sebagai makhluk hidup, manusia tentunya tidak lepas dari emosi, baik emosi positif maupun emosi negatif. Menurut Goleman (dalam Susiati, 2017), emosi merujuk pada suatu perasaan dan pikiranpikiran khasnya, suatu keadaan biologis dan psikologis serta serangkaian kecenderungan untuk bertindak. Emosi positif adalah ungkapan jiwa seseorang untuk menyatakan perasaan senang atau gembira. Sebaliknya, emosi negatif adalah ungkapan jiwa seseorang untuk menyatakan perasaan sakit hati, marah, kecewa, sedih, terkejut, kesal, dan sebagainya yang dapat diungkapkan melalui bahasa. Hal ini dipertegas pula oleh Khodijah (2006) bahwa emosi negatif didasari oleh terhalangnya keinginan, sehingga bisa menyebabkan frustasi. Dalam menyampaikan maksudnya atau mengungkapkan emosinya itu, manusia menggunakan bahasa yang berbeda-beda.

Pemakaian tuturan emosi tidak terlepas dari beberapa hal yang memengaruhinya yaitu latar atau suasana. Keterkaitan penggunaan bahasa dengan konteks (situasi tutur) yang menyertai bahasa tersebut merupakan salah satu hal yang menarik dalam kajian pragmatik menurut Baskoro (2014), pragmatik mengkaji struktur bahasa secara eksternal, yakni bagaimana satuan kebahasaan digunakan di dalam berkomunikasi. Penggunaan bahasa dalam percakapan sehari-hari kadang-kadang mengandung makna yang berbeda dalam konteks yang berbeda pula. Dengan kata lain, arti dari sebuah kata harus disesuaikan dengan konteks kalimatnya. Yule (2014), menjelaskan pragmatik adalah studi tentang makna yang disampaikan oleh penutur (penulis) dan ditafsirkan oleh pendengar (pembaca) pendengar berusaha menafsirkan tuturan penutur sehingga akan diperoleh makna, maksud, tujuan dari penutur. Setelah pendengar mengetahui maksud penutur maka akan diketahui jenis tindakan yang harus dilakukan oleh pendengar. Untuk itu yang menjadi pusat perhatian pragmatik adalah maksud penutur yang terdapat dibalik tuturan yang diutarakan.

Seiring perkembangan waktu dalam dunia mahasiswa seringkali kita temukan beragam kebiasaan yang tidak terlepas, yaitu demonstrasi yang mana kegiatan ini merupakan aksi menyampaikan aspirasi di tempat umum dengan maksud dan tujuan menyuarakan segala macam kebijakankebijakan yang diambil oleh pemegang otoritas (pemimpin atau penguasa) yang tidak prorakyat. Dalam menyampaiakan aspirasinya orang yang berdemostrasi memakai bahasa sebagai perantara dengan wujud formal hal ini didukung pula pendapat Rahardi (2005), wujud tuturan adalah jenis atau ragam tuturan yang digunakan seorang penutur dalam menyampaikan pesan kepada mitra tutur. Di setiap negara demokrasi termasuk Indonesia segala bentuk aspirasi rakyat bisa disampaiakan secara bebas dan terbuka. Menurut Savero (2008), demonstrasi adalah tindakan untuk menyampaikan penolakan, kritik, ketidakberpihakan, mengajari hal-hal yang dianggap sebuah penyimpangan. Terlepas dari semua itu seringkali peserta demonstrasi dalam menyampaikan aspirasinya cenderung menggunakan tuturan emosi dalam isi penyampaiannya. Dalam setiap tuturan terlihat penggunaan piranti linguistik yang mewujudkan suatu tuturan,termasuk tuturan emosi dalam ranah demonstrasi. Bentuk tuturan emosi dalam ranah demonstrasi dapat berwujud kata, frasa, kalimat, maupun ungkapan yang di 
dalamnya disesuaikan dengan jenis tuturan emosi yang terungkapkan.

Tujuan penelitian ini, yaitu menganalisis bentuk dan jenis tuturan emosi mahasiswa Kota Baubau dalam ranah demonstrasi.

\section{LANDASAN TEORI}

\section{Pragmatik}

Levinson (dalam Nababan, 1987) menyatakan bahwa pragmatik memiliki dua pengertian, pertama kajian dari hubungan antara bahasa dan konteks yang mendasari penjelasan dari pengertian bahasa. Pengertian bahasa menunjukkan kepada fakta bahwa untuk mengerti suatu ungkapan atau ujaran bahasa yang diperwakilkan oleh pengetahuan di luar makna kata dan hubungannya dengan konteks pemakainya. Kedua, kajian tentang kemampuan pemakaian bahasa mengaitkan kalimatkalimat dengan konteks-konteks yang sesuai bagi kalimat-kalimat itu.

Menurut Leech (1993), pragmatik adalah studi tentang makna dalam hubungannya dengan situasi ujar (speech situations). Pragmatik diperlukan dengan menganalisis makna yang dipertuturkan antara penutur disesuaikan dengan situasi ujar.

Hal senada juga di ungkapkan oleh Gusnawaty (2011) pragmatik berfokus utama pada dua kunci, yakni penggunaan bahasa dan konteksnya; dan makna yang ditimbulkan akibat interaksi sosial yang bergantung pada hubungan solidaritas atau jarak antara interlokutor. Cahyono (1995) menyatakan bahwa pragmatik merupakan cabang ilmu bahasa yang mempelajari tentang makna yang dikehendaki oleh penutur, pendapat tersebut lebih menekankan pada makna yang dikehendaki penutur.

\section{Tindak Tutur}

Tindak tutur (speech art) merupakan unsur pragmatik yang melibatkan pembicara, pendengar atau penulis pembaca serta yang dibicarakan. Dalam penerapannya tindak tutur digunakan oleh beberapa disiplin ilmu. Adapun pengertian tindak tutur yang dikemukakan oleh para ahli bahasa, antara lain Austin, Searle, Chaer, dan Tarigan.

Austin (dalam Rusminto, 2010) pertama kali mengemukakan istilah tindak tutur. Austin mengemukakan bahwa aktivitas bertutur tidak hanya terbatas pada penuturan sesuatu, tetapi juga melakukan sesuatu atas dasar tuturan itu. Pendapat Austin ini didukung oleh Searle (dalam Rusminto, 2010) dengan mengatakan bahwa unit terkecil komunikasi bukanlah kalimat, melainkan tindakan tertentu, seperti membuat pernyataan, pertanyaan, perintah, dan permintaan.

Berdasarkan uraian beberapa tokoh di atas dapat disimpulkan bahwa tindak tutur adalah suatu ujaran yang mengandung tindakan sebagai suatu fungsional dalam komunikasi yang mempertimbangkan aspek situasi tutur.

\section{Situasi Tutur}

Situasi tutur adalah situasi yang melahirkan tuturan. Pernyataan ini sejalan dengan pandangan bahwa tuturan merupakan akibat, sedangkan situasi tutur merupakan sebabnya. Di dalam komunikasi tidak ada tuturan tanpa situasi tutur. Situasi tutur sangat penting di dalam pragmatik.

Maksud tuturan yang sebenarnya hanya dapat diidentifikasi melalui situasi tutur yang mendukungnya. Rustono (1999) menyatakan bahwa tidak selamanya tuturan itu secara langsung menggambarkan makna yang dikandung oleh unsur-unsurnya.

Rahardi (2002) membagi aspekaspek situasi tutur menjadi lima macam, yaitu:

1) Penutur dan lawan tutur

Penutur dan lawan tutur di dalam beberapa literatur, khususnya dalam Searle (dalam Rustono, 1999) lazim dilambangkan dengan S (speaker) yang berarti pembicara atau penutur, dan $\mathrm{H}$ (hearer) yang dapat diartikan pendengar atau mitra tutur. Lambang $\mathrm{S}$ dan $\mathrm{H}$ itu tidak semata-mata hanya dengan sendirinya membatasi 
cakupan pragmatik hanya pada bahasa ragam lisan saja, melainkan dapat mencakup ragam bahasa tulis.

2) Konteks tuturan

Konteks tuturan telah diartikan beragam oleh para linguis. Konteks dapat mencakup aspek-aspek tuturan yang relevan baik secara fisik maupun nonfisik. Konteks dapat pula diartikan sebagai semua latar belakang pengetahuan yang diasumsikan sama-sama dimiliki penutur dan mitra tutur serta yang mendukung interpretasi mitra tutur atas apa yang dimaksudkan penutur dalam proses bertutur.

\section{3) Tujuan tuturan}

Tujuan tuturan berkaitan erat dengan bentuk tuturan seseorang. Dikatakan demikian karena pada dasarnya tuturan itu terwujud karena dilatarbelakangi oleh maksud dan tujuan tutur yang jelas dan tertentu sifatnya. Secara pragmatik, suatu bentuk tutur dapat memiliki maksud dan tujuan tutur dapat diwujudkan dengan bentuk tuturan yang berbeda-beda.

\section{4) Tuturan sebagai tindakan}

Tuturan sebagai bentuk tindakan atau aktivitas merupakan bidang yang ditangani pragmatik karena pragmatik mempelajari tindak yang terdapat dalam situasi tutur tertentu. Dapat dikatakan bahwa yang dibicarakan dalam pragmatik bersifat konkret karena jelas keberadaan siapa peserta tuturannya, di mana tempat tuturannya, kapan waktu tuturannya, dan seperti apa konteks situasi tuturnya secara keseluruhan.

\section{5) Tuturan sebagai produk tindak verbal}

Tuturan dapat dipandang sebagai produk tindak verbal karena pada dasarnya tuturan yang ada dalam sebuah pertuturan itu adalah hasil tindak verbal para peserta tutur dengan segala pertimbangan konteks yang melingkupi dan mewadahinya.

\section{Komponen Tutur}

Pemakaian bahasa dalam komunikasi, selain ditentukan oleh faktor- faktor linguistik juga ditentukan oleh faktor-faktor yang bersifat nonlinguistik.Pandangan tersebut beralasan bahasa merupakan bagian yang tidak terpisahkan dari sistem sosial. Menurut Poedjosoedarmo (dalam Rahardi, 2002) faktor luar bahasa (extra linguistic) yang dikatakan sebagai penentu penggunaan bahasa dalam bertutur dapat disebut sebagai komponen tutur (component of speech). Setiap tuturan atau ujaran manusia dalam berkomunikasi selalu berkaitan erat dengan komponen tutur. Namun, tidak semua komponen tutur muncul sekaligus dalam sebuah tuturan. Hal ini disebabkan setiap komponen tutur tersebut memiliki peran dan fungsi yang berbeda dalam membentuk sebuah tuturan.

Sejalan dengan masalah yang diteliti, dipakai dasar penelitian yang menyatakan bahwa wujud ujaran (speech) atau tuturan (utterance)itu ditentukan dan dipengaruhi oleh beberapa faktor. Hymes (dalam Chaer, 2012) membuat formulasi tentang faktorfaktor penentu sebuah tuturan yang apabila huruf-huruf pertamanya dirangkaikan menjadi akronim SPEAKING. Kedelapan faktor tersebut yaitu:

1) Setting berkenaan dengan waktu dan tempat tutur berlangsung, sedangkan scene mengacu pada situasi tempat dan waktu, atau situasi psikologis pembicaraan.

2) Participants adalah pihak-pihak yang terlibat dalam tuturan. Misalnya, pembicara dan pendengar, penyapa dan pesapa, atau pengirim dan penerima (pesan). Status sosial partisipan sangat menentukan ragam bahasa yang digunakan petutur.

3) Ends merujuk pada maksud dan tujuan pertuturan. Peristiwa tutur yang terjadi di ruang pengadilan bermaksud untuk menyelesaikan suatu kasus perkara; namun, para partisipan di dalam peristiwa tutur itu mempunyai tujuan yang berbeda. Jaksa ingin membuktikan kesalahan 
si terdakwa, pembela berusaha membuktikan bahwa si terdakwa tidak bersalah, sedangkan hakim berusaha memberikan keputusan yang adil.

4) Act sequences mengacu pada bentuk ujaran dan isi ujaran. Bentuk ujaran ini berkenaan dengan kata-kata yang digunakan, bagaimana penggunaannya, dan hubungan antara apa yang dikatakan dengan topik pembicaraan.

5) Key mengacu pada nada, cara, dan semangat yang mana suatu pesan disampaikan: dengan senang hati, dengan serius, dengan singkat, dengan sombong, dengan mengejek, dan lainlain. Hal ini dapat juga ditunjukkan dengan gerak tubuh dan isyarat.

6) Instrumentalities mengacu pada jalur bahasa yang digunakan seperti jalur lisan, tertulis, melalui telegraf atau telepon. Instrumentalities ini juga mengacu pada kode ujaran yang digunakan, seperti bahasa dialek, ragam, atau register.

7) Norm of interaction and interpretation mengacu pada norma atau aturan dalam berinteraksi. Selain itu, juga mengacu pada norma penafsiran terhadap ujaran dari lawan bicara.

8) Genre mengacu pada jenis bentuk penyampaian, seperti narasi, puisi, pepatah, doa, dan lain-lain.

\section{Emosi}

Emosi berasal dari kata emotusatau emovere yang artinya 'mencerca' (to stir up), yaitu sesuatu yang mendorong terhadap sesuatu (Dirgagunarsa, dalam Nurhayati, 2006). Misalnya, emosi gembira mendorong perubahan suasana hati seseorang yang menyebabkan orang itu tertawa. Marah, dilain pihak, merupakan suasana hati untuk menyerang atau mencerca sesuatu. Emosi pada umumnya disifatkan sebagai keadaan (state) yang ada pada individu atau organisme pada sesuatu waktu. Misalnya, seseorang merasa sedih, senang, takut, marah ataupun gejala-gejala yang lain setelah melihat, mendengar atau merasakan sesuatu.

Menurut Walgito (2003) emosi merupakan reaksi yang kompleks yang mengandung aktivitas dengan derajat yang tinggi dan adanya perubahan dalam kejasmanian serta berkaitan dengan perasaan yang kuat. Oleh karena itu, emosi lebih intens dari pada perasaan, dan sering terjadi perubahan perilaku, hubungan dengan lingkungan kadang-kadang terganggu.

Nurhayati (2006), mengatakan bahwa perasaan menyangkut keadaan kejiwaan dan keadaan jasmani. Selanjutnya, perasaan ini jika terlalu berlebihan, maka untuk mengadakan hubungan dengan sekitarnya terganggu, hal ini akan memasuki wilayah emosi.

Dari beberapa pengertian tokoh di atas, maka dapat didefinisikan bahwa tuturan emosi adalah bentuk bahasa yang merupakan hasil dari pengungkapan, pengeluaran, atau pengucapan segala macam perasaan dari jiwa seseorang. Pengertian tuturan di sini sama sekali tidak dihubungkan dengan pengertian tuturan yang bermakna semacam peribahasa.

\section{Jenis-jenis Emosi}

Beberapa tokoh mengemukakan tentang jenis-jenis emosi antara lain, Decrates membagi emosi atas enam bentuk yaitudesire (hasrat), hate (benci), sorrow (sedih/duka), wonder (heran), love (cinta) dan joy (kegembiraan).

Watson (dalam Mahmud, 1989:23) membagi tiga jenis emosi, yaitu:

1) Takut

Rasa takut mempunyai nilai positif dan negatif. Positif, karena rasa takut melindungi individu dalam keadaan yang berbahaya.

2) Marah 
Marah adalah tindakan yang timbul dari dalam diri seseorang karena tekanan dari perasaan.

3) Cinta

Cinta adalah perasaan manusia sebagai pemenuhan kerinduan akan kesatuan.

Goleman (dalam Susiati,2017) mengemukakan beberapa jenis emosi yang tidak jauh berbeda dengan ketiga tokoh di atas, yaitu (a) Amarah adalah salah satu bentuk emosi yang di dalamnya meliputi brutal, mengamuk, benci, marah besar, jengkel, kesal hati, terganggu, rasa pahit, tersinggung, bermusuhan, tindak kekerasan dan kebencian patologis; (b) Kesedihan adalah salah satu bentuk emosi yang di dalamnya meliputi pedih, sedih, muram, suram, melankolis, mengasihani diri, kesepian, ditolak, putus asa, dan depresi; (c) Rasa takut adalah salah satu bentuk emosi yang di dalamnya adalah cemas, takut, gugup, khawatir, was-was, ngeri, kecut, panik, dan fobia; (d) Kenikmatan adalah salah satu bentuk emosi yang di dalamnya adalah bahagia, gembira, ringan, puas, senang, terhibur, bangga, takjub, terpesona, lega, dan girang; (e) Cinta adalah salah satu bentuk emosi yang di dalamnya meliputi penerimaan, persahabatan, kepercayaan, kebaikan hati, rasa dekat, bakti, hormat, kasmaran, dan kasih sayang; (f) Terkejut adalah salah satu bentuk emosi yang meliputi takjub dan terpana; (g) Jengkel adalah salah satu bentuk emosi yang meliputi hina, jijik, muak, mual, benci, dan tidak suka; (h) Malu adalah salah satu bentuk emosi yang meliputi rasa bersalah, malu hati, kesal hati, menyesal, dan aib.

Ekman (2008) mengemukakan bahwa manusia memiliki enam emosi dasar, yaitu (a) fear atau takut, (b) anger atau marah, (c) sadness atau sedih, (d) happiness atau bahagia, (e) disgust atau jijik, dan (f) surprise atau terkejut. Emosi dasar ini dipercaya dimiliki oleh semua manusia dari budaya manapun juga.

Bagi manusia, emosi tidak hanya berfungsi untuk survival atau sekadar untuk mempertahankan hidup, seperti pada hewan. Akan tetapi, emosi juga berfungsi sebagai energizer atau pembangkit energi yang memberikan kegairahan dalam kehidupan manusia. Selain itu, emosi juga merupakan messenger atau pembawa pesan (Khodijah, 2006).

Khodijah (2006) membagi tiga macam fungsi emosi manusia, yaitu:

1) Survival

Survivaladalah sarana untuk mempertahankan hidup. Emosi memberikan kekuatan pada manusia untuk membedakan dan mempertahankan diri terhadap adanya gangguan atau rintangan. Adanya perasaan cinta, sayang, cemburu, marah atau benci, membuat manusia dapat menikmati dalam kebersamaan dengan manusia lain.

\section{2) Energizer}

Energizer yaitu sebagai pembangkit energi. Emosi dapat memberikan manusia semangat dalam bekerja bahkan juga semangat untuk hidup. Contohnya perasaan cinta dan sayang. Namun, emosi juga dapat memberikan dampak negatif yang membuat manusia merasakan hari-hari yang suram dan nyaris tidak ada semangat untuk hidup. Contohnya perasaan sedih dan benci.

\section{3) Messenger}

Messenger sebagai pembawa pesan.

Emosi memberitahu kita bagaimana keadaan orang-orang yang ada di sekitar kita, terutama orang-orang yang kita cintai dan sayangi. Sehingga kita dapat memahami dan melakukan sesuatu yang tepat dengan kondisi tersebut.

Berkaitan dengan itu, Goleman dan Hammen (dalam Rakhmat, 2001) menyebutkan empat fungsi emosi (a) Emosi adalah pembangkit energi (energizer). Tanpa emosi, kita tidak sadar atau mati. Hidup berarti merasai, mengalami, bereaksi, dan bertindak. Emosi membangkitkan dan memobilisasi energi kita, marah menggerakkan kita untuk menyerang. Takut menggerakkan kita untuk berlari. Dan cinta mendorong kita untuk mendekat dan bermesraan; (b) Emosi adalah pembawa 
informasi (messenger); (c) Emosi bukan hanya membawa informasi dalam komunikasi interpersonal; (d) Emosi juga merupakan sumber informasi tentang keberhasilan.

Berdasarkan beberapa pendapat tokoh di atas dapat disimpulkan bahwa emosi sangat berfungsi dan memengaruhi kehidupan manusia. Pengaruh emosi lebih terasa apabila manusia dihadapkan pada situasi lingkungan yang ada di sekitarnya dan fungsi dari emosi bisa dijadikan sebagai pengendalian perilaku.

\section{Teori Emosi}

Para ahli mengemukakan beberapa teori dalam upaya menjelaskan timbulnya gejala emosi, beberapa teori tersebut antara lain:

1) Teori emosi dua-faktor Schacter-Singer

Teori ini dikenal sebagai teori yang paling klasik yang berorientasi pada rangsangan. Reaksi fisilogik misalnya, hati berdebar, tekanan darah naik, napas bertambah cepat, adrenalin dialirkan dalam darah. Jika rangsangannya menyenangkan dalam hal ini ketika seseorang merasa gembira seperti diterima di perguruan tinggi idaman, emosi seperti ini disebut emosi senang, sebaliknya jika rangsanganya membahayakan misalnya, melihat ular berbisa yang akan timbul dinamakan taktik.

\section{2) Teori emosi James-Lange}

Teori ini menjelaskan bahwa emosi adalah hasil persepsi seseorang terhadap perubahan-perubahan yang terjadi pada tubuh sebagai respons terhadap berbagai rangsangan yang datang dari luar. Jika misalnya seseorang melihat harimau, reaksinya adalah peredaran darah makin cepat memompa udara. Respons tubuh ini kemudian dipersepsikan timbullah rasa takut. Rasa takut timbul oleh hasil pengalaman dan proses belajar. Orang bersangkutan dari hasil pengalamannya telah mengetahui bahwa harimau adalah makhluk yang berbahaya karena itu debaran jantung dipersepsikan sebagai rasa takut.

\section{3) Teori emosi Emergency Cannon}

Teori ini menyatakan emosi timbul bersama-sama dengan reaksi fisologik. Teori Cannon kemudian diperkuat oleh Philp Bard, sehingga kemudian lebih dikenal dengan teori Cannon-Bard atau teori emergency. Teori ini menjelaskan bahwa emosi adalah reaksi yang diberikan oleh organisme dalam situasi darurat atau emergency. Teori ini didasarkan pada pendapat bahwa ada antagonisme pada saraf-saraf simpatis dengan cabangcabangcranial dansacral pada susunan saraf otonom. Jadi, kalau saraf-saraf simpatis aktif, maka secara otomatif saraf-saraf otonom nonaktif, dan begitu sebaliknya.

\section{Bentuk Tuturan Emosi}

Pada dasarnya setiap jenis kata apapun bisa menjadi kata emosi. Namun, ada dua hal yang menjadi persyaratan minimal bagi sebuah kata untuk menjadi sebuah tuturan emosi, yaitu intonasi dan tujuan. Kedua syarat ini menjadi faktor pembeda antara sebuah kata emosi dengan sebuah kata biasa.

Nurhayati (2006) bahasa emosi dapat saja berbentuk satu kata, misalnya kata awas! Mewakili emosi marah, kata sayang mewakili emosi senang (gembira). Dalam frasa dapat ditemukan bahasa emosi, misalnya akan sedih, hendak marah, dan lain-lain. Selain itu, dapat pula berbentuk kalimat silakan duduk sayang. Bahasa emosi dapat pula berbentuk ungkapan misalnya, lupa kacang akan kulitnya (ungkapan yang bernada mengejek).

Tuturan emosi ini mempunyai variasi bentuk. Tuturan ini dapat berbentuk kata, frasa, kalimat, dan ungkapan. Beragamnya persoalan yangterjadi dalam lingkup pemerintah dan masyarakat akan menyebabkan pula keragaman bentukbentuk tuturan emosi yang diigunakan oleh mahasiswa saat berdemonstrasi.

\section{1) Kata Tunggal}

Menurut Kridalaksana (1993) kata (word) adalah (a) morfem atau kombinasi morfem yang oleh bahasawan dianggap 
sebagai satuan terkecil yang dapat diujarkan sebagai bentuk yang bebas; (b) satuan bahasa yang dapat berdiri sendiri, terjadi di morfem tunggal atau gabungan morfem.

\section{2) Kata Kompleks}

Kata kompleks adalah kata yang sudah mengalami proses morfologis. Kata tersebut dapat dibedakan menjadi tiga, yaitu (a) kata berimbuhan; (b) kata ulang; (c) kata majemuk. Kata berimbuhan adalah kata yang dibentuk dengan proses afiksasi, sedangkan kata ulang adalah kata yang dibentuk dengan proses reduplikasi. Menurut Kridalaksana (1993) kata majemuk adalah gabungan morfem dasar yang seluruhnya berstatus sebagai kata yang mempunyai pola fonologis, gramatikal, dan semantik yang khusus menurut kaidah yang bersangkutan.

\section{3) Bentuk Frasa}

Menurut Kridalaksana (2008) frasa (phrase) adalah gabungan dua kata atau lebih yang sifatnya tidak predikatif; gabungan itu rapat dapat renggang; misalnya mafia uang, universitas elit.

\section{4) Bentuk Kalimat}

Kalimat (sentence) adalah (a) satuan bahasa yang secara relatif berdiri sendiri, mempunyai pola intonasi final dan secara aktual maupun potensial terdiri atas klausa; (b) klausa bebas yang menjadi bagian kognitif percakapan; satuan proposisi yang merupakan gabungan klausa atau merupakan satu klausa, yang membentuk satuan yang bebas; jawabanminimal, seruan, salam, dan sebagainya; (c) konstruksi gramatikal yang terdiri atas satu atau lebih klausa yang ditata menurut pola tertentu, dan dapat berdiri sendiri sebagai satu satuan (Kridalaksana, 2008).

\section{5) Ungkapan}

Ungkapan adalah gabungan dua kata atau lebih yang digunakan seseorang dalam situasi tertentu untuk mengiaskan suatu hal. Ungkapan terbentuk dari gabungan dua kata atau lebih. Gabungan kata ini jika tidak ada konteks yang menyertainya memiliki dua kemungkinan makna, yaitu makna denotasi dan makna konotasi.

\section{METODE PENELITIAN}

\section{Pendekatan dan Jenis Penelitian}

Penelitian ini merupakan jenis penelitian deskriptif kualitatif dengan menggunakanpendekatan pragmatik. Dengan demikian, pendeskripsian data penelitian ini berupa tuturan emosi mahasiswa Kota Baubau dalam ranah demonstrasi dari segi bentuk dan jenis dengan menggunakan konsep-konsep teori yang dikembangkan oleh para ahli pragmatik. Pendekatan pragmatik digunakan untuk menjelaskan penggunaan tuturan emosi dari aspek konteks atau situasi tutur.

\section{Sumber Data dan Jenis Data}

Sumber data penilitian ini, yaitu empat bentuk demonstrasi mahasiswa Kota Baubau 1) Peringatan hari buru; 2) Perpanjangan izin prodi FKIP Universitas Dayanu Ikhsanuddin; 3) Tuntutan janji kampanye Ketua Yayasan Universitas Dayanu Iksanuddin; 4) Aksi damai IMM. Jenis data pada penelitian ini terbagi atas dua, yaitu data primer dan data sekunder.Data primer adalah data yang diperoleh atau langsung dikumpulkan di lapangan oleh orang yang melakukan penelitian. Jadi, dalam penelitian ini yang menjadi data primer adalah seluruh tuturan mahasiswa Kota Baubau pada saat berdemonstrasi, sedangkan data sekunder adalah data yang dikumpulkan oleh orang yang melakukan penelitian dari sumber yang telah ada.

\section{Populasi dan Sampel}

Populasi merupakan jumlah keseluruhan pemakaian bahasa tertentu yang tidak diketahui batas-batasnya akibat dari banyaknya yang memakai (dari ribuan sampai jutaan), lamanya pemakaian (disepanjang hidup penutur-penuturnya), dan luasnya daerah serta lingkungan pemakaian". Ringkasnya populasi pemakaian bahasa sama dengan jumlah 
keseluruhan pemakaian bahasa, baik yang akan dipilih maupun tidak dipilih untuk dianalisis. Oleh karena itu, populasi data penelitian ini adalah keseluruhan tuturan emosi mahasiswa Kota Baubau dalam ranah demonstrasi.

Penentuan sampel dalam penelitian ini dilakukan dengan cara purposif.Adapun sampel yang digunakan dalam penelitian ini sebanyak enam puluh empat kalimat yang dituturkan oleh nahasiswa pada empat bentuk demonstrasi. Enam puluh empat kalimat tersebut dianalisis berupa bentuk dan jenis penggunaan tuturan emosi tersebut.

\section{Teknik Analisis Data}

Analisis pada penelitian ini adalah menangani langsung masalah yang terkandung dalam data. Penerapan langkahlangkah dalam teknik analisis data pada penelitian ini sebagai berikut.Persiapan dilakukan dengan menyiapkan seluruh data lapangan, baik berupa rekaman, atau catatan lapangan. Data berupa rekaman suara tersebut ditranskrip atau disalin dalam bentuk tulisan.Penyeleksian datatuturan emosi mahasiswa Kota Baubau yang terdapat dalam rekaman tersebut diseleksi dan ditentukan menurut rumusan masalah yang diteliti yaitu, bentuk dan jenis tuturan emosi tersebut.

Data-data yang diidentifikasi sebelumnya, diklasifikasikan berdasarkan permasalahan yang ada, yakni bentuk dan jenis tuturan emosi mahasiswa Kota Baubau dalamranah demonstrasi. Dalam penelitian ini klasifikasi dilakukan dengan menggunakan data sesuai dengan tujuan penelitian yang ingin dicapai dan disertakan dengan nomor urut data.Contoh: nomor urut (1) merupakan data satu dan nomor (2) merupakan data dua dan seterusnya.Penganalisisan data yang telah diklasifikasi, kemudian dianalisis dengan mendeksripsikan secara mendetail permasalahan yang terdapat dalam data yang telah dikumpulkan berdasarkan teori yang berkaitan dengan bentuk dan jenis tuturan emosi sebagai dasar pedoman dalam
menganalisis.Penyimpulan

hasil

analisispenyimpulan terhadap semua fokus masalah (bentuk dan jenis) sebagai karakteristik tuturan emosi mahasiswa Kota Baubau dalam ranah demonstrasi.

\section{PEMBAHASAN}

Berdasarkan hasil penelitian, ditemukan empat bentuk piranti linguistik tuturan emosi mahasiswa Kota Baubau dalam ranah demonstrasi, yaitu kata, frasa, kalimat, dan ungkapan. Selanjutnya, jenis tuturan emosi mahasiswa Kota Baubau dalam ranah demonstrasi, yaitu pada bentuk kata, jenis emosi hanya tampak pada emosi amarah, kesedihan, rasa takut, dan jengkel. Selanjutnya pada bentuk frasa, jenis emosi terlihat pada emosi amarah, kesedihan, dan jengkel, serta jenis emosi yang ditemukan pada bentuk kalimat, yaitu emosi amarah, kesedihan, rasa takut, kenikmatan, dan jengkel. Sementara dalam bentuk ungkapan hanya tampak pada jenis emosi jengkel.

Telah diutarakan pada bagian awal tentang hasil penelitian, bahwa penelitian ini menemukan berbagai bentuk dan jenis tuturan emosi mahasiswa Kota Baubau dalam ranah demonstrasi. Bentuk tuturan emosi mahasiswa Kota Baubau dalam ranah demonstrasi diantaranya (1) kata, (2) frasa, (3) kalimat, dan (4) ungkapan serta jenis tuturan emosi mahasiswa Kota Baubau dalam ranah demonstrasi, yaitu amarah, kesedihan, rasa takut, dan jengkel yang hanya tampak pada bentuk kata. Jenis emosi yang ditemukan pada bentuk frasa, yaitu amarah, kesedihan, dan jengkel. Selanjutnya pada bentuk kalimat ditemukan emosi amarah, kesedihan, rasa takut, kenikmatan dan jengkel, serta bentuk ungkapan hanya tampak pada jenis emosi jengkel.

Seperti telah dipaparkan di atas bahwa wujud tuturan emosi mahasiswa Kota Baubau dalam bentuk kata hanya tampak pada emosi amarah, kesedihan, rasa takut, dan jengkel. Adapun bentuk kata pada jenis emosi tersebut adalah, amarah (huforia, dihipnotis, cerita, juga, jadi dan ingat), kesedihan (mengharapkan, susah, dari, korban, dan biarlah), rasa takut 
(mengingatkan, perhatikan, moga dan moga), dan jengkel (lagi-lagi, katanya, gobrok (goblok), bahkan, menuntut, konon, dan malah). Bentuk frasa dalam jenis emosi amarah, yaitu rintihan rakyatmu, telah diporak-porandakkan, nyata kebohongan, nyata korupsi, nyata penindasan, dan bosan sekali. Wujud frasa dalam jenis emosi kesedihan adalah saksi sejarah, bahkan nihil, dan lagi-lagi solusi. Selanjutnya, bentuk frasa dalam emosi jengkel, yaitu kata sejahtera, buat apa, kalau toh, janji lagi, dan ribuan orang. Bentuk kalimat dalam jenis emosi amarah, yaitu ditandai dengan penanda lingual kalimat interogatif, kalimat deklaratif, dan kalimat imperatif. Bentuk kalimat dalam jenis emosi kesedihan adalah kalimat deklaratif dan kalimat imperatif. Selanjutnya, bentuk kalimat dalam emosi rasa takut dan emosi kenikmatan menggunakan penanda lingual kalimat deklaratif serta bentuk kalimat dalam emosi jengkel menggunakan kalimat interogatif, kalimat imperatif, dan kalimat deklaratif.Pada penelitian ini, penggunaan bentuk ungkapan tuturan emosi mahasiswa Kota Baubau dalam ranah demonstrasi hanya tampak pada emosi jengkel. Bentuk ungkapan tersebut menggunakan penanda lingual seperti, isi perutnya, panjang tangan, pelacur demokrasi, rahim bangsa, dan harga mati.

\section{Emosi Amarah}

Berikut ini contoh analisis bentuk kata, frasa, dan kalimat,tuturan emosi amarah dalam ranah demonstrasi.

\section{Contoh (1)}

Orator 1: ...Hari buru bukanlah sekadar huforia (euphoria) yang mengandung kesenangan.

Contoh (1) di atas termasuk tuturan emosi yang mengandung emosi amarah. Hal tersebut tampak dari wujud kata tunggal huforia (euforia) yang digunakan oleh orator 1. Kata huforia adalah bentuk ungkapan yang secara tekstual bermakna kegembiraan atau kesenangan. Pada situasi ini penutur mengungkapkan tuturanya dengan mimik merah dan suara keras. Namun apabila kata ini digunakan pada situasi yang lain misalnya pada saat mengajak teman untuk berlibur tentu tidak termasuk sebagai kategori emosi. Hal ini dapat disimpulkan bahwa secara kontekstual makna kata euforia bermakna negatif yang digunakan oleh penutur untuk menyatakan kekesalannya terhadap pemerintah yang dianggap oleh orator 1, bahwa mereka (pemerintah) hanya menjadikan Hari Buruh sebagai aksi yang tidak mempunyai manfaat.

\section{Contoh (2)}

Orator 2: ... Maka kalau amanah itu kau laksanakan maka dengarlah rintihan rakyatmu ini. Pemerintah yang konon memberikan lapangan pekerjaan yang layak untuk mensejahterakan rakyatnya akan tetapi hari ini Kota Baubau telah diporak-porandakan oleh oknum-oknum yang hanya mementingkan isi perutnya. ...

Melalui contoh (2) di atas terlihat emosi amarah yang dituturkan oleh orator 2 . Bentuk emosi amarah adalah frasa verbal rintihan rakyatmu. Frasa rintihan rakyatmu mempunyai makna leksikal, yaitu adanya masyarakat yang kesakitan secara fisik. Pada situasi ini penutur mengungkapkan tuturanya dengan suara keras dan lantang. Penutur menggunakan bentuk frasa tersebut tidak sesuai dengan konteks sebenarnya karena kata rintihan diasosiasikan dengan masyarakat yang kesakitan secara non fisik. Pada konteks ini orator 2 memilih frasa rintihan rakyatmu sebagai bentuk kemarahannya terhadap pemerintah yang dianggap oleh penutur bahwa pemerintah acuh tak acuh terhadap nasib masyarakat dan kurangnya lapangan pekerjaan yang disediakan oleh pemerintah. 
Contoh (3)

Orator 2 : Wahai para pemegang kebijakan bukankah engkau telah dititipkan amanah oleh rakyatmu untuk memperbaiki kehidupan masyarakatmu?... Bukan kesejahteraan yang diciptakan tetapi hanyalah cerita indah dimasa kampanye.

Contoh (3) di atas termasuk tuturan emosi yang dituturkan oleh orator 2. Hal tersebut tampak dari wujud kalimat wahai para pemegang kebijakan bukankah engkau telah dititipkan amanah oleh rakyatmu untuk memperbaiki kehidupan masyarakatmu? Piranti linguistik yang menjadi penandanya adalah kalimat interogatif. Penutur menggunakan kalimat tersebut sebagai bentuk pertanyaan terhadap fungsi pemerintah yang disesuaikan dengan konteks sebenarnya, yaitu fungsi pemerintah untuk melayani rakyatnya. Tuturan tersebut apabila disampaikan secara tertulis bukan lisan maka dapat dikatakan bahwa tuturan tersebut tidak mengandung emosi. Hal ini digunakan oleh orator 2 sebagai bentuk amarahnya terhadap pemerintah yang dinilai oleh mahasiswa bahwa kinerja pemerintah Kota Baubau tidak maksimal.

\section{Emosi Kesedihan}

Berikut ini salah satu contoh analisis bentuk kata, frasa, dan kalimat tuturan emosi kesedihan dalam ranah demonstrasi.

\section{Contoh (4)}

Orator 3 :... dari tahun dua ribu sepuluh yang lalu izin prodi selalu menjadi masalah. Fakultas Teknik, Fakultas Hukum telah duluan menjadi korban bahkan melalui demonstrasi akhirnya tercapai solusi.

Contoh (4) di atas tampak emosi kesedihan yang dituturkan oleh orator 3. Hal ini dapat dilihat pada tuturan di atas. Piranti linguistik yang menjadi penandanya adalah kata dari dan korban. Kata dari adalah bentuk kata yang mempunyai makna leksikal, yaitu permulaan peristiwa. Kata tersebut dikategorikan sebagai emosi karena pada saat penutur menungkapkannya dengan nada tinggi disertai dengan muka merah. Tuturan di atas dituturkan oleh orator 3 sesuai dengan keadaan sebenarnya, yaitu izin program studi selalu menjadi masalah tiap tahunnyadan kata korban pada tuturan tersebut adalah adanya pihak yang dirugikan. Pada konteks ini penutur menggunakan bentuk tuturannya sesuai dengan keadaan sebenarnya karena pihak yang dirugikan adalah mahasiswa ketika izin program studi tidak dapat diselesaikan oleh pihak kampus.

\section{Contoh (5)}

Orator 3: ... Wahai generasi muda apakah engkau hanya menjadi saksi sejarah? ...

Melalui contoh (5) terlihat emosi kesedihan yang dituturkan oleh orator 3, yaitu wahai generasi mudah apakah engkau hanya menjadi saksi sejarah? Piranti linguistik yang menjadi penandanya adalah frasa nomina saksi sejarah. Frasa saksi sejarah berarti orang yang mengetahui sebuah peristiwa. Hal ini digunakan oleh penutur tidak sesuai dengan konteks sebenarnya.Penutur menggunakan tuturan tersebut sebagai bukti kepeduliannya terhadap generasi muda Kota Baubau karena dianggap oleh orator 3 bahwa generasi muda hanya diam dalam melihat persoalan layaknya saksi dari peristiwa itu.

\section{Contoh (6)}

Orator 1 : ... Hari buru adalah hari dimana semua rintihan para pekerja se-Indonesia disuarakan.Buruh adalah pekerja yang ikhlas dengan niat berusaha menghidupi sanak familinya bahkan rela menahan terik matahari demi tercapainya tujuan hidup yang baik. ... 
Dalam tuturan contoh (6) di atas tampak tuturan emosi yang dituturkan oleh orator 1. Hal ini dapat dilihat dari tuturan Hari Buru adalah hari dimana semua rintihan para pekerja se-Indonesia disuarakan. Kalimat tersebut merupakan kalimat deklatif yang mengandung jenis emosi kesedihan. Pada konteks ini penutur menggunakan bentuk kalimat tidak sesuai dengan keadaan sebenarnya karena kata kerja rintihan merupakan bentuk keluhan masyarakat yang didenotasikan oleh orator 1. Penutur menggunakan kalimat tersebut sebagai bentuk kesedihannya terhadap nasib buru yang kurang diperhatikan oleh pemerintah.

\section{Emosi Rasa Takut}

Berikut ini salah satu contoh analisis bentuk kata dan kalimat tuturan emosi rasa takut dalam ranah demonstrasi.

\section{Contoh (7)}

Orator 1: ... Di sini kami hadir bukanlah sebagai pemegang kebijakan tetapi kami hadir di sini untuk mengingatkan kepada seluruh masyarakat Kota Baubau untuk tidak salah memilih pemimpin yang ada di Kota ini.

Dalam contoh (7) di atas tampak adanya bentuk tuturan emosi yang dituturkan oleh orator 1. Bentuk emosi rasa takut pada tuturan tersebut adalah kata kompleks mengingatkan. Kata mengingatkan adalah memberitahukan sesuatu. Penutur menggunakan kata tersebut tidak sesuai dengan konteks karena peristiwa yang menjadi kekhawatiran orator 1 belum terbukti. Namun, hal ini penutur memakai kata tersebut sebagai bentuk rasa takut terhadap keputusan yang akan diambil oleh masyarakat di pemilihan walikota kelak.

\section{Contoh (8)}

Orator 3 : ... Karena, jangan sampai yang kaya makin kaya ...
Dari contoh (8) di atas tergambar tuturan emosi rasa takut yang berbentuk kalimat deklaratif. Hal ini tampak melalui tuturan karena jangan sampai yang kaya makin kaya yang dituturkan oleh orator 3 . Penutur menggunakan bentuk kalimat tersebut tidak sesuai dengan konteks sebab kebenaran tuturannya hanya sebatas asumsi. Hal ini digunakan oleh orator 3 sebagai bentuk kekhawatirannya terhadap nasib masyarakat Kota Baubau.

\section{Emosi Jengkel}

Berikut ini contoh analisis bentuk kata, frasa, kalimat, dan ungkapan tuturan emosi jengkel dalam ranah demonstrasi.

\section{Contoh (9)}

Orator 1 :... Karena, lagi-lagi sudah terlalu banyak yang menampakkan dirinya untuk menjadi pemimpin di Kota ini layaknya sebuah ajang pencarian bakat dalam dunia selebriti....

Pada contoh (9) di atas termasuk tuturan emosi Jengkel. Hal ini terlihat dari wujud kata kompleks lagi-lagi yang digunakan oleh orator 1. Kata lagi-lagi adalah kata yang mengandung peristiwa berulang kejadiannya. Pada konteks ini penutur menggunakan kata tersebut sebagai bentuk kejengkelannya terhadap para calon walikota yang hanya pintar berjanji. Orator 1 menyesuaikan tuturannya dengan konteks di Kota Baubau, yaitu maraknya pemasangan baliho para calon Walikota Baubau yang kejadiannya dianggap oleh penutur sebagai kebiasaan saat pencalonan kepala daerah di kota itu.

\section{Contoh (10)}

Orator 2 : ...Tetapi pengelolaannya yang bobrok oleh para elit-elit politik yang kemudian menyebabkan masyarakat jauh dari kata sejahtera....

Contoh (10) di atas termasuk tuturan emosi. Hal tersebut tampak dari tuturan 
orator 2, yaitu tetapi pengelolaannya yang bobrok oleh para elit-elit politik yang kemudian menyebabkan masyarakat jauh dari kata sejahtera. Piranti linguistik yang menjadi penandanya adalah frasa adjektiva para elit-elit politik yang mengandung jenis emosi Jengkel. Penutur memilih frasa tersebut sesuai dengan konteks sebenarnya sebagai bentuk rasa jengkelnya terhadap pemerintah yang dianggap tidak efisien dalam mengelola sumber daya alam yang di Kota Baubau.

\section{Emosi Kenikmatan}

Berikut ini contoh analisis bentuk kalimat tuturan emosi kenikmatan dalam ranah demonstrasi.

\section{Contoh (11)}

Orator 1 : Assalamu alaikum. Kita kembali mengumandangkan cerita ini setiap tahunnya untuk mengingatkan kembali para pengambil kebijakan...

Melalui contoh (1) di atas tampak tuturan emosi yang dituturkan oleh orator 1 . Hal ini dapat dilihat pada tuturan di atas. Piranti linguistik yang menjadi penandanya adalah kalimat deklaratif assalamu alaikum yang mengandung jenis emosi kenikmatan. Kalimat tersebut mempunyai makna leksikal sebagai ucapan salam kepada lawan bicara. Penutur menggunakan bentuk kalimat tersebut sebagai bentuk penghargaannya kepada masyarakat Kota Baubau maupun mahasiswa yang menyaksikan demonstrasi mereka. Tuturan tersebut diucapkan dengan rasa bangga dengan suara karena ucapan tersebut dapat melahirkan hubungan baik antara penutur dengan pendengar.

\section{PENUTUP}

Berdasarkan hasil kajian bab sebelumnya (hasil dan pembahasan), penulis dapat menarik beberapa kesimpulan yang selaras dengan tujuan penelitian, yaitu. Bentuk dan jenis tuturan emosi mahasiswa Kota Baubau dalam ranah demonstrasi berdasarkan hasil analisis data, penelitian ini menemukan.

1. Bentuk kata pada jenis emosi tersebut adalah, amarah (huforia, dihipnotis, cerita, juga, jadi dan ingat), kesedihan (mengharapkan, susah, dari, korban, dan biarlah), rasa takut (mengingatkan, perhatikan, moga dan moga), dan jengkel (lagi-lagi, katanya, gobrok (goblok), bahkan, menuntut, konon, dan malah).

2. Bentuk frasa dalam jenis emosi amarah, yaitu rintihan rakyatmu, telah diporakporandakkan, nyata kebohongan, nyata korupsi, nyata penindasan, dan bosan sekali. Wujud frasa dalam jenis emosi kesedihan adalah saksi sejarah, bahkan nihil, dan lagi-lagi solusi. Selanjutnya, bentuk frasa dalam emosi jengkel, yaitu kata sejahtera, buat apa, kalau toh, janji lagi, dan ribuan orang.

3. Bentuk kalimat dalam jenis emosi amarah, yaitu ditandai dengan penanda lingual kalimat interogatif, kalimat deklaratif, dan kalimat imperatif. Bentuk kalimat dalam jenis emosi kesedihan adalah kalimat deklaratif (buru adalah pekerja yang ihklas dengan niat berusaha menghidupi sanak familinya bahkan rela menahan terik matahari demi tercapainya tujuan hidup yang baik dan (sebagai mahasiswa berikan kami solusi). Selanjutnya, bentuk kalimat dalam emosi rasa takut (wahai rektor ribuan teman kami serta orang tuanya khawatir dengan masalah ini) dan emosi kenikmatan menggunakan penanda lingual kalimat deklaratif (Assalamu alaikum dan Salam sejahtera) serta bentuk kalimat dalam emosi jengkel menggunakan kalimat interogatif (apakah dengan demonstrasi sehingga bisa memicu kinerja bapak dan ibu yang ada di kampus ini?), kalimat imperatif, dan kalimat deklaratif (lagi-lagi sudah terlalu banyak yang menampakkan dirinya untuk menjadi pemimpin di Kota ini layakanya sebuah ajang pencarian bakat dalam dunia selebriti). 
4. Bentuk ungkapan tuturan emosi mahasiswa Kota Baubau dalam ranah demonstrasi hanya tampak pada emosi jengkel. Bentuk ungkapan tersebut menggunakan penanda lingual seperti, isi perutnya, panjang tangan, pelacur demokrasi, rahim bangsa, dan harga mati.

5. Jenis tuturan emosi mahasiswa Kota Baubau dalam ranah demonstrasi, yaitu amarah, kesedihan, rasa takut, kenikmatan, dan jengkel.

\section{DATAR PUSTAKA}

Baskoro,S. 2014. "Pragmatik dan Wacana Korupsi"Jurnal Humaniora. Vol. 26, No 1. Yogyakarta: Universitas Gajah Mada.

Cahyono, Bambang Yudi. 1995. KristalKristal Ilmu Bahasa. Surabaya: Airlangga.

Chaer, A. 2012. Linguistik Umum. Jakarta: Rineka Cipta.

Ekman, Paul. 2008. Membaca Emosi Orang. Penerjemah: Abdul Qadir S. Yogyakarta: Think Yogyakarta.

Gusnawaty. 2011. "Perilaku Kesantunan dalam Bahasa Bugis Analisis Sosiopragmatik”. Disertasi. Makassar: Pascasarjan Universitas Hasanuddin.

Hasan. 2002. Pokok-pokok Materi Metodologi Penelitian dan Aplikasinya. Bogor: Ghalia.

Khodijah. 2006. Psikologi Pelajar. IAIN. Raden Fatah Press.

Kridalaksana, Harimurti. 1993. Kamus Linguistik. Edisi Ketiga. Jakarta: Gramedia Pustaka Utama.

Kridalaksana, Harimurti. 2008. Kamus Linguistik. Edisi Keempat. Jakarta: Gramedia Pustaka Utama.

Leech, Geoffrey. 1993. Prinsip-Prinsip Pragmatik. Penerjemah: M.D.D Oka. Jakarta: Penerbit Universitas Indonesia.
Mahmud, M.D. 1989. Psikologi Suatu Pengantar. Jakarta: Departemen Pendidikan dan Kebudayaan Direktorat Jenderal Pendidikan Tinggi Proyek Pengembangan Lembaga Pendidikan Tenaga Kependidikan.

Nababan, P.W.J. 1987. Ilmu Pragmatik, Teori dan Penerapannya. Jakarta: Gramedia.

Nurhayati. 2006. "Bahasa Emosi Wanita Karier di Kota Makassar Kajian Psikososiolinguistik".Disertasi. Makassar: Universitas Hasanuddin.

Rahardi. 2005. Sosiolinguistik, Kode, dan Alih Kode. Yogyakarta: Pustaka Pelajar.

Rakhmat, Djalaluddin. 2001. Metode Penelitian. Bandung. Angkasa.

Rusminto.2001. Pragmatik Teori dan Analisis. Surakarta: Pustaka.

Rustono. 1999. Pokok-Pokok Pragmatik. Semarang: CV. Ikip Semarang Press.

Savero, B. 2008. "Demonstrasion PerjuanganKontekstual":http//ww w.com (Selasa 26 mei 2008).

Susiati.2017. "Tuturan Emosi Bahasa Indonesia Verbal dan Nonverbal Suku Bajo Sampela: Kajian Psikolinguistik". Tesis. Universitas Hasanuddin.

Tarigan,H.G. 1990. Pengajaran Pragmatik. Bandung: Angkasa

Walgito, Bimo. 2003. Pengantar Psikologi Umum. Yogyakarta: Andi Offset.

Yule, G. 2014. Pragmatik. Penerjemah: Indah Fajar Wahyuni Yogyakarta: Pusataka Pelajar. 


\begin{tabular}{|lcl|}
\hline \multicolumn{3}{|c|}{ TOTOBUANG } \\
\hline Volume 6 & Nomor 1, Juni 2018 & Halaman 139—154 \\
\hline
\end{tabular}

\title{
STRATEGI PENANGANAN SOAL UKBI MENURUT DIMENSI SOAL FAKTUAL (Strategies of UKBI Question Management Based on Dimension of Factual Question)
}

\author{
Nanik Sumarsih \\ Balai Bahasa Daerah Istimewa Yogyakarta \\ Jalan I Dewa Nyoman Oka 34, kotabaru, Yogyakarta \\ Pos-el: nanikbudiyantoro@gmail.com
}

(Diterima: 15 Februari 2018; Direvisi 13 Mei 2018; Disetujui: 3 Juni 2018)

\begin{abstract}
This study discussed about the skill level of junior and senior high school teachers at Yogyakarta in answering the factually UKBI and handled question strategy according to factual question dimension.This research used descriptive quantitative approach.The research aimed to determine the good or poor languagelevel of the educators which had been measured by UKBI. Therefore, the result of this study wa originally presented by considering its productivity.The research followed several steps, they were: (1) collecting and classifying of data, (2) analysing data, (3) presenting analysis result.The ability of junior and senior high school teachers at DIY in answeingr factual question was $81 \%$. Based on the character of factual question, the strategy that should be used was that applying 5W 1H strategy (who, what, where, when, why, and how)_. This strategy can be described as follows: Who is asking about a person as doer. What is asking about an event that happens. Where is asking about where an event takes place. When is asking time when an event happens. Why is asking about reason why it happens. How is asking how an event happens.
\end{abstract}

Keywords: Language Proficiency, UKBI, Factual Question

\begin{abstract}
Abstrak
Kajian ini membahas tingkat kemahiran guru SLTP dan SLTA di Yogyakarta dalam menjawab soal UKBI yang bersifat faktual beserta strategi penanganan soal menurut dimensi soal faktual. Penelitian ini menggunakan pendekatan kuantitatif deskriptif. Hal ini dimaksudkan untuk menentukan baik buruk kemampuan berbahasa pendidik yang diukur berdasarkan UKBI. Oleh karena itu, hasil penelitian ini memaparkan apa adanya dengan mempertimbangkan produktivitasnya. Langkah penelitian mengikuti tahapan sebagai berikut. Pertama, pencarian dan klasifikasi data. Kedua, analisis data. Ketiga, penyampaian hasil analisis. Kemampuan guru SLTP dan SLTA di DIY dalam menjawab soal yang bersifat faktual masing-masing adalah $81 \%$. Berdasarkan sifat soal faktual, strategi yang dapat digunakan untuk menjawab bentuk penyoalan ini adalah $5 \mathrm{~W}$ $1 H$ (who, what, where, when, why, dan how)_Strategi ini dapat dijabarkan sebagai berikut. Who ialah tentang siapa? What, apa yang terjadi? Where, di mana peristiwa itu terjadi, when, kapan hal itu terjadi? Why, mengapa hal itu terjadi? How, bagaimana hal itu terjadi?
\end{abstract}

Kata Kunci: Kemahiran Berbahasa, UKBI, Soal Faktual

\section{PENDAHULUAN}

Berdasarkan penelitian terbatas pada tahun 2011 yang dilakukan oleh Solihah (2014:5) diketahui bahwa kemahiran guru di provinsi dengan UN rendah juga memperlihatkan hasil UKBI yang rendah. Sebaliknya, kemahiran berbahasa guru di provinsi yang perolehan UN tinggi juga menunjukkan kemahiran yang baik. Jadi, terdapat hubungan yang cukup signifikan antara kemahiran berbahasa Indonesia guru dengan perolehan UN siswa untuk mata pelajaran Bahasa Indonesia. Sehubungan dengan hal tersebut, dapat dikatakan bahwa guru yang memiliki kemahiran berbahasa Indonesia yang rendah ternyata dapat berimplikasi pada hasil belajar siswanya, khususnya untuk pelajaran Bahasa Indonesia.

Rendahnya kemampuan berbahasa Indonesia berdampak pada rendahnya kemampuan membaca dan kemampuan 
menulis siswa. Setidaknya guru harus memperoleh skor pada tingkat unggul agar dapat berdampak pada pembelajaran bahasa Indonesia yang menyenangkan dan mampu meningkatkan nilai UN bahasa Indonesia, sekaligus mengefektifkan proses pembelajaran yang ada.

Selain hasil UN bahasa Indonesia, isu strategis lain berkaitan dengan hasil PISA (Programme for International Student Assessment) dalam hal literasi membaca yang menyatakan bahwa pada tahun 2015 Indonesia meraih peringkat 64 dari 72 negara. Hal tersebut disebabkan oleh siswa Indonesia tidak dapat menjawab soal-soal yang bersifat analitis. Karena memang sampai saat ini, belum menjadi bagian dari proses pembelajaran sekolah-sekolah di Indonesia.

Terkait hal tersebut, sistem penyoalan dalam UKBI menawarkan konsep-konsep pemecahan masalah yang selama ini belum diterapkan di sekolahsekolah. Terdapat tiga jenis penyoalan dalam penyusunan soal UKBI. Salah satu jenis penyoalan adalah jenis penyoalan yang bersifat faktual. Penyoalan faktual adalah penyoalan mengenai pengetahuan tentangterminologi, detail, dan unsur (kejadian, detail, waktu, tempat, ukuraan, subjek tertentu).

Kajian mengenai strategi penanganan soal UKBI ini perlu dilakukan guna memberi wawasan kepada calon peserta uji agar lebih mudah memahami soal saat mengikuti tes UKBI. Kajian penelitian ini berjudul "Strategi Penanganan Soal UKBI Menurut Dimensi Soal Faktual". Penelitian ini bertujuan untuk memperoleh pemetaan tingkat kemahiran guru di DIY dalam menjawab soal yang bersifat faktual beserta strategi penanganan soalnya.

\section{LANDASAN TEORI}

Terdapat tiga dimensi penyoalan dalam UKBI, yaitu faktual, konseptual, dan prosedural (Maryanto, 2009:1-2). Dimensi penyoalan yang bersifat faktual yaitu pengetahuan tentangterminologi, detail, dan unsur (kejadian, detail, waktu, tempat, ukuraan, dan subjek tertentu). Dimensi penyoalan yang bersifat konseptual, yaitu pengetahuan tentang klasifikasi dan kategori; pengetahuan tentang berbagai prinsip dan generalisasi serta pengetahuan tentang berbagai teori, struktur, dan model. Dimensi penyoalan yang bersifat prosedural, yaitu pengetahuan tentang berbagai kecakapan khusus dan logaritma, pengetahuan tentang berbagai teknik khusus dan metode, dan pengetahuan tentang kriteria tertentu untuk menentukan kapan harus menggunakan prosedur yang tepat (Solihah, 2014:27-32).

Dimensi soal yang bersifat faktual memiliki ciri jawaban beracuan konkret (eksplisit di dalam teks atau wacana), jawaban berupa ingatan atau pemahaman, dan jawaban tidak memerlukan analisis. Dimensi soal yang bersifat konseptual memiliki ciri jawaban beracuan semi abstrak (implisit atau semiimplisit di dalam teks atau wacana), jawaban berupa penerapan atau jawaban memerlukan analisis, dan jawaban bukan berupa ingatan atau pahaman. Dimensi soal yang bersifat prosedural memiliki ciri jawaban beracuan abstrak (implisit di dalam teks/wacana), jawaban memerlukan analisis yang kompleks, dan jawaban memerlukan evaluasi.

Selain dimensi penyoalan, penyusunan soal UKBI juga memperhatikan ranahnya. Ranah adalah lingkungan yang memungkinkan terjadinya komunikasi, misalnya ranah ekonomi, ranah pertanian, ranah agama, dan ranah politik. Setiap ranah mencerminkan tingkat kerumitan yang berbeda berdasarkan kekhasan peristilahan. Penyoalan di dalam UKBI tidak dibatasi pada ranah tertentu, tetapi justru seberagam mungkin. Terdapat empat ranah yang digunakan dalam penyoalan UKBI, yaitu (1) sintas, (2) sosial, (3) vokasional, dan (4) akademik (Solihah, 2014:5-16).

Sintas memperlihatkan kesadaran berkomunikasi untuk kepentingan personal di tempat umum, misalnya komunikasi yang 
terwujud ketika seseorang membeli sesuatu di warung atau di perpustakaan. Fokus penceritaan pada kebutuhan atau keinginan orang/individu. Dengan wacana sintas, sekurang-kurangnya peserta uji dapat memahami bagaimana mengungkapkan diri, menyadari eksistensi diri atau potensi diri sebagai makhluk Tuhan, dan menyadari diri sebagai bagian dari keluarga dan lingkungan.

Sosial memperlihatkan gambaran tentang kesadaran berkomunikasi untuk kepentingan interpersonal yang merupakan komunikasi yang terwujud dalam mengekspresikan kerja sama, kepedulian, keperihatinan, dan kepekaan terhadap orang lain. Misalnya, ungkapan kepedulian terhadap dampak bencana alam dan ungkapan dalam membangun kerja sama dengan orang lain dalam arisan. Fokus penceritaan pada hubungan individu dan sesama anggota masyarakat. Dengan wacana sosial sekurang-kurangnya peserta uji dapat memahami bagaimana menjalin komunikasi dengan orang lain dalam rangka menjalin kerja sama, mengungkapkan kepedulian, mengungkapkan gagasan dalam meningkatkan hubungan, dan sebagainya.

Vokasional memperlihatkan kesadaran berkomunikasi mengenai perilaku produktif untuk menghasilkan barang atau jasa, misalnya pembuatan lem, penggunaan kamera, cara bertanam, konsultasi kesehatan, dan konsultasi hukum.

Akademik memperlihatkan kesadaran berkomunikasi mengenai perilaku keilmiahan untuk pengembangan ilmu dan pengetahuan, misalnya temuan ilmiah, diskusi ilmiah, laporan iptek, dan orasi ilmiah.

\section{METODE PENELITIAN}

Ada tiga tahapan dalam pelaksanaan penelitian ini, yaitu tahap pengumpulan data, tahap analisis data, dan tahap penyajian hasil analisis data (Sudaryanto 1993:5).
Pemaparan ketiga tahap tersebut sebagai berikut.

Data penelitian ini adalah tingkat kemahiran berbahasa Indonesia guru di Daerah Istimewa Yogyakarta berdasar hasil UKBI. Mengingat banyaknya guru yang telah mengikuti UKBI, dalam penelitian ini akan dibatasi untuk guru SLTP dan SLTA di Daerah Istimewa Yogyakarta yang mengikuti UKBI pada rentang uji tahun 2012-2013. Berkaitan dengan itu, data berupa hasil UKBI didapatkan dari tim UKBI Balai Bahasa DIY. Sumber data berupa template-template penilaian yang telah dilakukan oleh tim UKBI Balai Bahasa DIY.

Penelitian ini menggunakan pendekatan kuantitatif deskriptif. Hal ini dimaksudkan untuk menentukan baik buruk kemampuan berbahasa pendidik diukur berdasarkan UKBI. Oleh karena itu, hasil penelitian ini dipaparkan apa adanya dengan mempertimbangkan produktivitasnya.

Analisis data dilakukan dengan metode agih. Metode agih adalah metode yang pelaksanaannya menggunakan unsur penentu yang berupa unsur bahasa itu sendiri (Sudaryanto 1993:13-15). Pemanfaatkan metode ini untuk menangani model penyoalan yang memang memanfaatkan aspek-aspek kebahasaan, baik secara semantik, gramatikal, maupun pragmatik. Aspek semantik diterapkan apabila penyoalan berupa peristilahan atau pilihan kata; aspek gramatikal diterapkan apabila penyoalan berupa pengalimatan; dan aspek pragmatik diterapkan apabila penyoalan berupa tuturan.

Metode ini diterapkan dengan cara mengamati hasil uji yang telah dilakukan. Hasil uji yang telah dilakukan dipilih yang benar berdasarkan dimensi penyoalan UKBI. Dimensi penyoalan dalam UKBI dibedakan menjadi tiga, yaitu (1) faktual, (2) konseptual, dan (3) prosedural.

Penyajian hasil analisis menggunakan metode formal dan informal. Metode formal digunakan sebagai alat bantu 
penjelasan, ditampilkan beberapa tabel dan bagan. Dengan metode informal, hasil penelitian ini dideskripsikan dengan menggunakan ekspresi tulis bahasa Indonesia.

\section{PEMBAHASAN}

Tingkat Kemahiran Guru SLTP dan SLTA di Yogyakarta dalam Menjawab Soal yang Bersifat Faktual

Pada bagian ini akan dipaparkan hasil tes UKBI terhadap soal faktual. Hasil tes tersebut meliputi jawaban terhadap soalsoal tes yang berupa soal faktual. Hasil tes tersebut dipilah berdasar kelompok guru SLTP dan guru SLTA.

Tingkat Kemahiran Guru SLTP dalam Menjawab Soal yang Bersifat Faktual

Peserta guru Bahasa Indonesia tingkat SLTP di Daerah Istimewa Yogyakarta yang mengikuti tes UKBI sebanyak seratus orang. Sejumlah peserta tersebut telah mengerjakan soal UKBI termasuk soal faktual pada tes UKBI ini yang berjumlah 22 soal. Jawaban soal faktual peserta UKBI guru Bahasa Indonesia tingkat SLTP di Daerah Istimewa Yogyakarta dapat diamati pada tabel 1 berikut.

Tabel 1

Tingkat Kemahiran Guru SLTP di DIY dalam Menjawab Soal yang Bersifat Faktual

\begin{tabular}{|c|c|c|c|c|}
\hline No. & $\begin{array}{c}\text { Jumlah Jawaban } \\
\text { Benar }\end{array}$ & $\begin{array}{c}\text { Jumlah Peserta } \\
\text { yang Menjawab } \\
\text { Benar }\end{array}$ & $\begin{array}{c}\text { Persentase } \\
(\%)\end{array}$ & $\begin{array}{c}\text { Rerata } \\
\text { Jumlah } \\
\text { Jawaban } \\
\text { Benar }\end{array}$ \\
\hline 1. & 11 & 2 & 2 & \multirow{12}{*}{$\begin{array}{c}18 \\
(1805: 100)\end{array}$} \\
\hline 2. & 12 & 2 & 2 & \\
\hline 3. & 13 & 3 & 3 & \\
\hline 4. & 14 & 1 & 1 & \\
\hline 5. & 15 & 3 & 3 & \\
\hline 6. & 16 & 7 & 7 & \\
\hline 7. & 17 & 16 & 16 & \\
\hline 8. & 18 & 19 & 19 & \\
\hline 9. & 19 & 18 & 18 & \\
\hline 10. & 20 & 18 & 18 & \\
\hline 11. & 21 & 9 & 9 & \\
\hline 12. & 22 & 2 & 2 & \\
\hline
\end{tabular}

Berdasarkan tabel 1 peserta yang mampu menjawab 11 soal faktual dengan benar adalah 2 orang atau 2 persen. Peserta yang mampu menjawab 12 soal faktual dengan benar adalah 2 orang atau 2 persen. Peserta yang mampu menjawab 13 soal faktual dengan benar adalah 3 orang atau 3 persen. Peserta yang mampu menjawab 14 soal faktual dengan benar adalah 1 orang atau 1 persen. Peserta yang mampu menjawab 15 soal faktual dengan benar adalah 3 orang atau 3 persen. Peserta yang mampu menjawab 16 soal faktual dengan benar sejumlah 7 orang atau 7 persen. Peserta yang mampu menjawab 17 soal faktual dengan benar sejumlah 16 orang atau 16 persen. Peserta yang mampu menjawab 18 soal faktual dengan benar sejumlah 19 orang atau 19 persen. Peserta yang mampu menjawab 19 soal faktual dengan benar sejumlah 18 orang atau 18 persen. Peserta yang mampu menjawab 20 soal faktual dengan benar sejumlah 18 orang atau 18 persen. Peserta yang mampu menjawab 21 
soal faktual dengan benar sejumlah 9 orang atau 9 persen. Peserta yang mampu menjawab 22 soal faktual dengan benar sejumlah 2 orang atau 2 persen.

Kemampuan guru Bahasa Indonesia tingkat SLTP di Daerah Istimewa Yogyakarta secara umum dalam menjawab soal faktual dapat diketahui dengan cara menentukan rerata jumlah peserta yang mampu menjawab soal dengan benar. Berdasarkan jumlah jawaban tersebut dapat diketahui rerata dari jumlah jawaban yang benar seluruh peserta UKBI pada data penelitian ini. Rerata yang diperoleh dari jumlah peserta yang mampu menjawab soal faktual dengan benar adalah 18 jawaban benar.

Dari hasil rerata yang telah diperoleh tersebut dapat dicari simpangan baku untuk menentukan batas toleransi peserta yang masih dianggap layak memiliki kemampuan rata-rata. Untuk memperoleh simpangan baku tersebut digunakan rumus yang telah ditentukan yaitu dengan $\sqrt{\frac{\sum X^{2}}{N}}$.

Tabel 2

Predikat Tingkat Kemahiran Guru SLTP di DIY dalam Menjawab Soal yang Bersifat Faktual

Berdasar Simpangan Baku

\begin{tabular}{|c|c|c|c|c|}
\hline No. & $\begin{array}{c}\text { Jumlah } \\
\text { Jawaban } \\
\text { Benar }\end{array}$ & $\begin{array}{c}\text { Jumlah Peserta } \\
\text { yang } \\
\text { Menjawab } \\
\text { Benar }\end{array}$ & Nilai $X^{2}$ & Predikat \\
\hline 1. & 11 & 2 & $X 1=-7 \rightarrow 49$ & \multirow{4}{*}{ Sangat tidak Mampu } \\
\hline 2. & 12 & 2 & $X 2=-6 \rightarrow 36$ & \\
\hline 3. & 13 & 3 & $X 3=-5 \rightarrow 25$ & \\
\hline 4. & 14 & 1 & $X 4=-4 \rightarrow 16$ & \\
\hline 5. & 15 & 3 & $X 5=-3 \rightarrow 9$ & Tidak Mampu \\
\hline 6. & 16 & 7 & $X 6=-2 \rightarrow 4$ & Kurang Mampu \\
\hline 7. & 17 & 16 & $X 7=-1 \rightarrow 1$ & Agak Mampu \\
\hline 8. & 18 & 19 & $\mathrm{X} 8=0 \rightarrow 0$ & Cukup Mampu \\
\hline 9. & 19 & 18 & $X 9=1 \rightarrow 1$ & Mampu \\
\hline 10. & 20 & 18 & $\mathrm{X} 10=2 \rightarrow 4$ & \multirow{3}{*}{ Sangat Mampu } \\
\hline 11. & 21 & 9 & $X 11=3 \rightarrow 9$ & \\
\hline 12. & 22 & 2 & $X 12=4 \rightarrow 16$ & \\
\hline & $\begin{array}{l}\frac{\sum X^{2}}{N X^{2}} \\
\frac{N}{\sqrt{\frac{\sum X^{2}}{N}}}\end{array}$ & & \multicolumn{2}{|l|}{$\begin{array}{l}170 \\
170: 100=1,7 \\
\sqrt{ } 1,7=1,3\end{array}$} \\
\hline
\end{tabular}

Berdasarkan tabel 2 dapat dinyatakan bahwa peserta yang mendapat predikat sangat tidak mampu adalah peserta yang mengerjakan soal dengan benar sebanyak 11, 12, 13, dan 14 soal. Dalam hal ini terdapat 8 orang yang memiliki predikat sangat tidak mampu. Peserta yang mendapat predikat tidak mampu adalah peserta yang mengerjakan soal dengan benar sebanyak 15 soal. Dengan kata lain terdapat 3 orang yang 
memiliki predikat tidak mampu. Peserta yang mendapat predikat kurang mampu adalah peserta yang mengerjakan soal dengan benar sebanyak 16 soal. Pada predikat ini terdapat 7 orang yang memiliki predikat kurang mampu. Peserta yang mendapat predikat agak mampu adalah peserta yang mengerjakan soal dengan benar sebanyak 17 soal. Dalam pengertian ini terdapat 16 orang yang memiliki predikat agak mampu. Peserta yang mendapat predikat mampu adalah peserta yang mengerjakan soal dengan benar sebanyak 19 soal. Pada capaian ini terdapat 18 orang yang memiliki predikat mampu. Peserta yang mendapat predikat sangat mampu adalah peserta yang mengerjakan soal dengan benar sebanyak 20, 21, dan 22 soal. Dalam hal ini terdapat 29 orang yang memiliki predikat sangat mampu.

Berdasarkan perolehan predikat tersebut dapat disimpulkan bahwa terdapat 34 orang peserta yang hanya dapat meraih predikat di bawah rerata, yaitu mereka yang mendapat predikat sangat tidak mampu, tidak mampu, kurang mampu, dan agak mampu. Sementara itu, terdapat 47 peserta yang meraih predikat di atas rerata, yaitu mereka yang mendapat predikat mampu dan sangat mampu. Oleh karena itu, perlu dilakukan pelatihan strategi mengerjakan soal faktual terutama kepada 34 peserta guru Bahasa Indonesia yang hanya mampu meraih predikat sangat tidak mampu, tidak mampu, kurang mampu, dan agak mampu.

\section{Tingkat Kemahiran Guru SLTA dalam} Menjawab Soal yang Bersifat Faktual

Seperti halnya peserta UKBI guru Bahasa Indonesia tingkat SLTP, peserta UKBI guru Bahasa Indonesia tingkat SLTA di Daerah Istimewa Yogyakarta yang mengikuti tes UKBI pada data penelitian ini sebanyak seratus orang. Seluruh peserta tersebut telah mengerjakan soal UKBI termasuk soal faktual pada tes UKBI yang berjumlah 22 soal. Jawaban soal faktual peserta guru Bahasa Indonesia tingkat SLTA di Daerah Istimewa Yogyakarta dapat diamati pada tabel berikut ini.

Tabel 3

Tingkat Kemahiran Guru SLTA di DIY dalam Menjawab Soal yang Bersifat Faktual

\begin{tabular}{|c|c|c|c|c|}
\hline No. & $\begin{array}{c}\text { Jumlah Jawaban } \\
\text { Benar }\end{array}$ & $\begin{array}{c}\text { Jumlah Peserta } \\
\text { yang Menjawab } \\
\text { Benar }\end{array}$ & $\begin{array}{c}\text { Persentase } \\
(\%)\end{array}$ & $\begin{array}{c}\text { Rerata } \\
\text { Jumlah } \\
\text { Jawaban } \\
\text { Benar }\end{array}$ \\
\hline 1. & 10 & 1 & 1 & \multirow{13}{*}{$\begin{array}{c}18 \\
(1797: 100)\end{array}$} \\
\hline 2. & 11 & 1 & 1 & \\
\hline 3. & 12 & - & - & \\
\hline 4. & 13 & 3 & 3 & \\
\hline 5. & 14 & 3 & 3 & \\
\hline 6. & 15 & 6 & 6 & \\
\hline 7. & 16 & 11 & 11 & \\
\hline 8. & 17 & 16 & 16 & \\
\hline 9. & 18 & 9 & 9 & \\
\hline 10. & 19 & 19 & 19 & \\
\hline 11. & 20 & 20 & 20 & \\
\hline 12. & 21 & 8 & 8 & \\
\hline 13. & 22 & 3 & 3 & \\
\hline
\end{tabular}


Berdasarkan tabel 3 tersebut dapat dikatakan bahwa peserta yang mampu menjawab 10 soal faktual dengan benar adalah 1 orang atau 1 persen. Peserta yang mampu menjawab 11 soal faktual dengan benar adalah1 orang atau 1 persen. Peserta yang mampu menjawab 13 soal faktual dengan benar adalah 3 orang atau 3 persen. Peserta yang mampu menjawab 14 soal faktual dengan benar adalah 3 orang atau 3 persen. Peserta yang mampu menjawab 15 soal faktual dengan benar adalah 6 orang atau 6 persen. Peserta yang mampu menjawab 16 soal faktual dengan benar sejumlah 11 orang atau 11 persen. Peserta yang mampu menjawab 17 soal faktual dengan benar sejumlah 16 orang atau 16 persen. Peserta yang mampu menjawab 18 soal faktual dengan benar sejumlah 9 orang atau 9 persen. Peserta yang mampu menjawab 19 soal faktual dengan benar sejumlah 19 orang atau 19 persen. Peserta yang mampu menjawab 20 soal faktual dengan benar sejumlah 20 orang atau 20 persen. Peserta yang mampu menjawab 21 soal faktual dengan benar sejumlah 8 orang atau 8 persen. Peserta yang mampu menjawab 22 soal faktual dengan benar sejumlah 3 orang atau 3 persen.

Berdasarkan tabel tersebut dapat disimpulkan bahwa jumlah jawaban benar paling banyak dikerjakan peserta adalah 22 jawaban yang benar dari 22 soal faktual. Dari jawaban tersebut, peserta yang menjawab 22 soal dengan benar sebanyak 3 orang atau 3 persen. Sementara itu, jumlah jawaban benar yang paling sedikit dikerjakan oleh peserta adalah 10 jawaban. Peserta yang menjawab 10 sebanyak 1 orang atau sebanyak 1 persen.

Kemampuan secara umum untuk menjawab soal UKBI guru Bahasa Indonesia tingkat SLTA di Daerah Istimewa Yogyakarta dapat diketahui dengan cara menentukan rerata jumlah peserta yang mampu menjawab soal dengan benar. Berdasarkan jumlah jawaban tersebut dapat diketahui rerata dari jumlah jawaban yang benar seluruh peserta UKBI pada data penelitian ini. Rerata yang diperoleh dari jumlah peserta yang mampu menjawab soal UKBI dengan benar adalah 18 jawaban yang benar.

Dari hasil rerata yang telah diperoleh tersebut dapat dicari simpangan baku untuk menentukan batas toleransi peserta yang masih dianggap layak memiliki kemampuan rata-rata. Untuk memperoleh simpangan baku tersebut digunakan rumus yang telah ditentukan yaitu dengan $\sqrt{\frac{\sum X^{2}}{N}}$.

Tabel 4

Predikat Tingkat Kemahiran Guru SLTA di DIY dalam Menjawab Soal yang Bersifat Faktual Berdasar Simpangan Baku

\begin{tabular}{|c|c|c|c|c|}
\hline No. & $\begin{array}{c}\text { Jumlah } \\
\text { Jawaban } \\
\text { Benar }\end{array}$ & $\begin{array}{c}\text { Jumlah Peserta } \\
\text { yang } \\
\text { Menjawab } \\
\text { Benar }\end{array}$ & Nilai $X^{2}$ & Predikat \\
\hline 1. & 10 & 1 & $X 1=-8 \rightarrow 64$ & \multirow{2}{*}{ Sangat tidak Mampu } \\
\hline 2. & 11 & 1 & $X 2=-7 \rightarrow 49$ & \\
\hline 3. & 12 & - & $X 3=-6 \rightarrow 36$ & \multirow{2}{*}{ Tidak Mampu } \\
\hline 4. & 13 & 3 & $X 4=-5 \rightarrow 25$ & \\
\hline 5. & 14 & 3 & $X 5=-4 \rightarrow 16$ & \multirow{2}{*}{ Kurang Mampu } \\
\hline 6. & 15 & 6 & $X 6=-3 \rightarrow 9$ & \\
\hline
\end{tabular}


Totobuang, Vol. 6, No. 1, Juni 2018: 139-154

\begin{tabular}{|c|c|c|l|l|}
\hline 7. & 16 & 11 & $\mathrm{X} 7=-2 \rightarrow 4$ & \multirow{2}{*}{ Agak Mampu } \\
\hline 8. & 17 & 16 & $\mathrm{X} 8=-1 \rightarrow 1$ & \multirow{2}{*}{ Cukup Mampu } \\
\hline 9. & 18 & 9 & $\mathrm{X} 9=0 \rightarrow 0$ & \multirow{2}{*}{ Mampu } \\
\hline 10. & 19 & 19 & $\mathrm{X} 10=1 \rightarrow 1$ & \multirow{2}{*}{ Sangat Mampu } \\
\hline 11. & 20 & 20 & $\mathrm{X} 11=2 \rightarrow 4$ & \\
\hline 12. & 21 & 8 & $\mathrm{X} 12=3 \rightarrow 9$ & \\
\hline 13. & 22 & 3 & $\mathrm{X} 13=4 \rightarrow 16$ & \\
& $\sum X^{2}$ & & 234 & \\
& $\frac{\sum X^{2}}{N}$ & & $\sqrt{ } 234: 34=1,53$ & \\
& $\sqrt{\frac{\sum X^{2}}{N}}$ & & & \\
& & & & \\
\end{tabular}

Berdasarkan tabel tersebut dapat dinyatakan bahwa peserta yang mendapat predikat sangat tidak mampu adalah peserta yang mengerjakan soal dengan benar sebanyak 10 dan 11 soal. Dalam hal ini terdapat 2 orang yang memiliki predikat sangat tidak mampu. Peserta yang mendapat predikat tidak mampu adalah peserta yang mengerjakan soal dengan benar sebanyak 12 dan 13 soal. Dengan kata lain terdapat 3 orang yang memiliki predikat tidak mampu. Peserta yang mendapat predikat kurang mampu adalah peserta yang mengerjakan soal dengan benar sebanyak 14 dan 15 soal. Pada kondisi ini terdapat 9 orang yang memiliki predikat kurang mampu. Peserta yang mendapat predikat agak mampu adalah peserta yang mengerjakan soal dengan benar sebanyak 16 dan 17 soal. Dalam pengertian ini terdapat 27 orang yang memiliki predikat agak mampu. Peserta yang mendapat predikat cukup mampu adalah peserta yang mengerjakan soal dengan benar sebanyak 18 soal. Dalam pengertian ini terdapat 9 orang yang memiliki predikat cukup mampu. Peserta yang mendapat predikat mampu adalah peserta yang mengerjakan soal dengan benar sebanyak 19 dan 20 soal. Pada capaian ini terdapat 39 orang yang memiliki predikat mampu. Peserta yang mendapat predikat sangat mampu adalah peserta yang mengerjakan soal dengan benar sebanyak 21 dan 22 soal. Dalam hal ini terdapat 11 orang yang memiliki predikat sangat mampu.

Berdasarkan perolehan predikat tersebut dapat disimpulkan bahwa terdapat 41 peserta yang hanya dapat meraih predikat di bawah rerata, yaitu mereka yang mendapat predikat sangat tidak mampu, tidak mampu, dan kurang mampu. Sementara itu, terdapat 50 peserta yang meraih predikat di atas rerata, yaitu mereka yang mendapat predikat mampu dan sangat mampu. Oleh karena itu, perlu dilakukan pelatihan strategi mengerjakan soal faktual terutama kepada 41 peserta guru Bahasa Indonesia tingkat SLTAyang hanya mampu meraih predikat sangat tidak mampu, tidak mampu, agak mampu, dan kurang mampu.

\section{Strategi Penanganan Soal Menurut Dimensi Soal Faktual}

Dimensi penyoalan dalam UKBI berupa dimensi pengetahuan. Ada tiga dimensi penyoalan, yaitu faktual, konseptual, dan prosedural. Faktual adalah pengetahuan tentang terminologi, detail, dan unsur (kejadian, detail, waktu, tempat, ukuran, subjek tertentu). Konseptual adalah pengetahuan tentang klasifikasi dan 
kategori, pengetahuantentang berbagai prinsip dan generalisasi, pengetahuantentang berbagai teori, struktur, dan model. Prosedural adalah pengetahuan tentang berbagai kecakapan khusus dan logaritma, pengetahuan tentang berbagai teknik khusus dan metode, pengetahuan tentang kriteria tertentu untuk menentukan kapan harus menggunakan prosedur yang tepat.

Dimensi pengetahuan tersebut diwujudkan dalam dimensi kognitif yang berupa mengingat, memahami, menganalisis, dan mengevaluasi (Solihah, 2014:25). Penyoalan yang menggunakan dimensi mengingat diwujudkan dengan cara mengungkapkan kembali, rekognisi (mengidentifikasi/mengenali). Penyoalan yang menggunakan dimensi memahami diwujudkan dengan cara menafsirkan, mengelompokkan, menyimpulkan, mengklasifikasi, membuat perbandingan, memberikan penjelasan. Penyoalan yang menggunakan dimensi menganalisis diwujudkan dengan cara membedakan, menyusun ulang, melengkapi, menguraikan, mengintegrasikan. Penyoalan yang menggunakan dimensi mengevaluasi diwujudkan dengan cara memberikan kritik (penilaian), membuat hipotesis. Berikut paparan lebih lanjut mengenai strategi penangan soal UKBI, yang bersifat faktual.

Dimensi penyoalan yang bersifat faktual merupakan dimensi penyoalan yang paling sederhana. Jawaban dari dimensi penyoalan ini beracuan konkret (eksplisit di dalam teks/wacana sehingga jawaban berupa ingatan/pemahaman dan tidak memerlukan analisis.

Pertanyaan faktual dapat berupa nama, identitas (misalnya, pria, wanita, anak-anak, dewasa, orang tua), profesi (misalnya, mahasiswa, guru), waktu, lokasi/tempat, bentuk, peristiwa/kejadian, jumlah, ukuran (panjang, luas, isi), jenis, alat, cara tindakan.
Berdasar sifat faktual tersebut strategi yang dapat digunakan untuk menjawab bentuk penyoalan ini adalah dengan menggunakan strategi $5 \mathrm{~W} 1 \mathrm{H}$, yaitu who, what, where, when, why, dan how. Strategi ini dapat dijabarkan sebagai berikut. Who ialah tentang siapa? What, apa yang terjadi? Where, di mana peristiwa itu terjadi, when, kapan hal itu terjadi? Why, mengapa hal itu terjadi? How, bagaimana hal itu terjadi?

\section{Who}

Kata tanya who berisi pertanyaan mengenai siapa. Contoh pertanyaan yang menggunakan kata tanya who. Siapa yang melakukan perbuatan itu? Siapa yang menjadi korban dari perbuatan itu? Siapa yang merasa dirugikan olehnya? Siapa yang menyuruhnya melakukan perbuatan itu? Siapa yang terlibat di dalam peristiwa itu?

\section{Dengarkanlah dialog berikut. "MEMILIH TEMPAT TINGAL" Pemain : Pasangan suami istri muda

Lokasi : Ruang pameran
perumahan

Istri : Jangan tergesa membeli ya.

Suami : Kita melihat-lihat dulu! Membeli rumah kan tidak seperti membeli pisang goreng. Banyak yang harus dipertimbangkan.

Istri : Menurutku, rumah haruslah nyaman, aman, dan tenteram. Rumah kan tempat melepas lelah sesudah seharian terkuras pekerjaan.

Suami : Yang juga perlu diperhatikan, yaitu lokasi dan kondisi. Lokasi harus mudah dicapai dengan transportasi umum. Yang kedua, kondisi. Artinya, kondisi lokasi bukan termasuk daerah rawan banjir, gempa, atau tanah longsor. Juga jauh dari pusat industri. 
Istri : Bagi kita, yang penting untuk beberapa tahun ke depan, yaitu jarak ke fasilitas pendidikan anak, minimal TK dan SD. Kalau lebih dari $1 \mathrm{~km}$, rasanya bisa merepotkan. Oya, lalu bagaimana juga dengan jarak ke fasilitas lain, seperti tempat ibadah, pasar, puskemas, lapangan olahraga, atau ruang terbuka hijau.

Suami : Aku setuju saja. Tapi, juga perlu kita pertimbangkan, yaitu kondisi lahan: datar atau miring. Sebaiknya, kita menghindari lahan miring.

Istri : Masih banyak, lho! Misalnya, perihal infrastruktur: tersedia tidaknya jaringan listrik, telepon, dan sumber air bersih.

Suami : Yang sepertinya sepele, tapi vital, misalnya, lancar tidaknya saluran pembuangan air limbah. Namun, yang juga tidak kalah penting ialah kelengkapan surat, baik untuk status tanah maupun perizinan. Terakhir, tentang kualitas bangunan. Harus diperiksa apakah kualitas sudah seperti yang disebutkan di brosur.

Istri : Wah, banyak yang harus kita perhatikan, termasuk mengecek lokasi! Jadi, sepakat tak tergesa membeli.

Intisari, No. 543, Oktober 2008:42

Pilihlah satu jawaban berikut yang menurut Anda benar dengan menyilang huruf A, B, C, atau D.

Siapakah pasangan pelaku dialog?
(A) suami istri
(B) teman bermain
(C) sahabat karib
(D) kakak adik

Jawaban pertanyaan di atas sudah tertera dalam dialog. Pertanyaan tersebut menanyakan siapakah pasangan yang ada di dalam dialog. Jawaban dari pertanyaan tersebut adalah opsi (A) suami isteri seperti yang tercantum dalam dialog.

\section{What}

Kata tanya what berisi pertanyaan mengenai permasalahan atau hal yang terjadi pada suatu peristiwa. Selain peristiwa, kata tanya ini juga dapat digunakan untuk menanyakan benda, permasalahan, pendapat, dan lain-lain. Contoh pertanyaan yang menggunakan kata tanya what 'apa'. Apa yang sebenarnya terjadi?; apa yang sedang dilakukan olehnya?; apa yang dibawa oleh si pelaku ?; apa permasalahannya?; apa yang akan dilakukan olehnya?

\section{Dengarkanlah dialog berikut.}

Dialog antara guru (G) dan murid (M) di ruang kelas

G : Ardy, kenapa kamu terlambat lagi?

M : Anu Bu, Ardy tadi di jalan menemukan dompet.

G : Mana dompetnya?

M : Sudah saya kembalikan, Bu.

$\mathrm{G}$ : Dikembalikan dimana?

M : Pada pemiliknya, karena di dalam dompet ada alamatnya.

G : Ardy, kamu itu sudah berkali-kali terlambat dan selalu ada alasan.

M : Ini bukan salah Ardy, Bu.

G : Ardy, Ardy, sudah banyak alasan yang kau katakan pada Bu guru.

M : Maafkan Ardy, Bu guru.

G : Sebagai hukumannya, sekarang kamu membuat hitungan di bukumu dariangka satu hingga angka seratus.

M : Ya, Bu guru.

G : Itu bel berbunyi, anak-anak boleh pulang, kecuali Ardy.

M : Ada apa Bu guru saya disuruh tinggal?

G : Ada yang akan ibu bicarakan kepadamu.

M : Tentang apa Bu?

$\mathrm{G} \quad$ : Ardy Bu guru sangat prihatin atas nilai ulanganmu yang semakin menurun. 
M : Maafkan Ardy Bu.

G : Ibu khawatir kamu tidak naik kelas.

M : Jangan Bu guru.

$\mathrm{G}$ : Ada syaratnya.

M : Apa Bu guru?

$\mathrm{G}$ : Mulai sekarang kamu harus rajin, tidak boleh terlambat lagi.

M : Ya, Bu guru.

G : Hanya ini yang bisa Ibu katakan. terserah kamu.

M : Maafkan atas kesalahan Ardy Bu, mulai besok Ardy tidak akan terlambat lagi.

Pilihlah satu jawaban berikut yang menurut Anda benar dengan menyilang huruf A, B, C, atau D.

Apa yang ditemukan Ardy di jalan?
(A) Tas
(B) SIM
(C) Dompet
(D) STNK

Jawaban dari dimensi penyoalan faktual bersifat eksplisit. Jawaban tertuang di dalam bacaan sehingga tidak memerlukan analisis. Seperti pada contoh di atas empat opsi jawaban yang tercantum dalam bacaan adalah opsi (C) dompet. Hal tersebut dapat dilihat dari bentuk pertanyaannya yang menggunakan kata tanya "apa" dan jawaban yang tercantum dalam dialog adalah dompet yaitu pada dialog berikut.

$$
\begin{array}{cl}
\text { G } \quad \text { Ardy, kenapa kamu terlambat } \\
\text { lagi? } \\
\text { M : Anu Bu, Ardy tadi di jalan } \\
\text { menemukan dompet }
\end{array}
$$

\section{Where}

Kata tanya where 'di mana'
mengandung pertanyaan-pertanyaan
mengenai tempat atau lokasi sebuah
peristiwa terjadi. Contoh pertanyaan yang
menggunakan kata tanya where. Di mana
peristiwa itu terjadi? Di mana berita itu
dimuat? Di mana dia bersembunyi? Di

mana dia tertangkap? Di mana permasalahan itu pertama kali muncul?

\section{Dengarkanlah dialog berikut. "MEMILIH TEMPAT TINGAL" \\ Pemain : Pasangan suami istri \\ muda \\ Lokasi : Ruang pameran
perumahan \\ Dialog selanjutnya sama seperti contoh \\ di atas}

Pilihlah satu jawaban berikut yang menurut Anda benar dengan menyilang huruf $A, B, C$, atau D.

Dimanakah dialog tersebut berlangsung?

(A) Di teras rumah

(B) Ruang pameran perumahan

(C) Kantor pemasaran rumah

(D) Di lahan perumahan

Jawaban pertanyaan di atas sudah tertera dalam dialog. Pertanyaan tersebut menanyakan dimanakah dialog tersebut berlangsung. Jawaban dari pertanyaan tersebut adalah opsi (B) ruang pameran perumahan seperti yang tercantum dalam dialog.

When

Kata tanya when 'kapan' berisi pertanyaan-pertanyaan mengenai waktu terjadinya peristiwa, berita atau cerita yang terjadi. Contoh pertanyaan yang menggunakan kata tanya kapan. Kapan peristiwa itu terjadi? Kapan dia melakukan perbuatan itu? Kapan dia datang ke tempat itu? Kapan dia tiba di lokasi kejadian? Kapan dia kembali ke rumahnya?

\section{Dengarkanlah dialog berikut.}

Dialog antara seorang dokter (D) dengan seorang penyiar $(\mathrm{P})$ di sebuah stasiun radio.

$\mathrm{P} \quad$ : "Saat ini produk-produk antiseptik kian marak di pasaran."

D : "Ya, masyarakat sekarang ingin selalu hidup bersih dan steril."

P : "Apakah penggunaan antiseptik ini sudah yang terbaik, Dok?' 
D : "Ada hasil pengujian di sejumlah laboratorium yang mengungkapkan bahwa bakteri belum tentu mati, justru semakin kuat."

P : : "Hmm... Lalu, kapan sebenarnya kita memerlukan produk-produk antikuman ini?"

D : "Sebenarnya tidak semua kuman merugikan. Pakailah pada saat memerlukan, misalnya memakai sabun yang mengandung antiseptik pada saat kita terkena penyakit kulit, menggunakan cairan antiseptik pada saat air yang kita pakai dalam kondisi yang tidak baik."

P : "Apakah produk-produk seperti sabun, pasta gigi, atau kosmetik yang mengandung antiseptik dan yang tidak mengandung antiseptik mempunyai perbedaan yang signifikan?"

D : "Menurut hasil penelitian tidak ada perbedaan yang signifikan penggunaan barang-barang yang mengandung antiseptik dan yang tidak. Yang penting adalah dilakukan dengan benar, seperti mencuci tangan dengan benar."

P : "Jadi, yang penting pola hidup sehat ya, Dok?"

D : "Iya, jangan mentang-mentang sudah memakai cairan antiseptik, jadi lupa mencuci tangan."

Pilihlah satu jawaban berikut yang menurut Anda benar dengan menyilang huruf A, B, C, atau D.

Kapan kita memerlukan produk-produk antikuman?

(A) setiap saat

(B) sesuka hati

(C) saat memerlukan

(D) kapan pun

Sama seperti pertanyaan yang lain, jawaban dari dimensi penyoalan faktual bersifat eksplisit. Pada contoh di atas empat opsi jawaban yang tercantum dalam bacaan adalah opsi (C) saat memerlukan. Hal tersebut dapat dilihat dari bentuk pertanyaannya yang menggunakan kata tanya "kapan" dan jawaban yang tercantum dalam dialog adalah saat memerlukan, yaitu pada dialog berikut.

P : :"Hmm... Lalu, kapan sebenarnya kita memerlukan produk-produk antikuman ini?"

D : "Sebenarnya tidak semua kuman merugikan. Pakailah pada saat memerlukan, misalnya memakai sabun yang mengandung antiseptik pada saat kita terkena penyakit kulit, menggunakan cairan antiseptik pada saat air yang kita pakai dalam kondisi yang tidak baik."

Why

Kata tanya why 'mengapa'mengandung pertanyaanpertanyaan mengenai alasan atau motivasi terjadinya sebuah peristiwa. Tidak selamanya penggunaan kata tanya ini menghasilkan soal yang bersifat faktual. Soal dikatakan bersifat faktual jika opsi jawaban tertera atau eksplisit di dalam bacaan. Contoh pertanyaan yang menggunakan kata tanya why 'mengapa'. Mengapa hal tersebut bisa terjadi? Mengapa dia melakukan itu? Mengapa dia pergi ke tempat itu? Mengapa dia mengatakan seperti itu? Mengapa peristiwa itu menjadi sangat heboh?

\section{Bacalah bacaan berikut!}

Nama rosella belakangan naik daun. Bukan cuma rasanya yang asemasem segar yang bikin orang rindu untuk mencicipinya lagi dan lagi. Kelopak bunganya yang merah cabai, diyakini juga sebagai obat mujarab pengusir puluhan jenis gangguan tubuh.

Nama rosella tiba-tiba menarik perhatian, tentu karena khasiatnya mengusir berbagai keluhan tubuh. Mulai 
dari yang ringan seperti menjaga stamina, menurunkan panas, menurunkan tekanan darah, sampai yang lumayan berat seperti menurunkan kadar gula, menghambat tumbuhnya kanker, atau memulihkan ketergantungan obat.

Sekitar tahun 80-an serat rosella digunakan untuk pembuatan karung dan pakaian. Tapi kemudian nasibnya memburuk digusur pemakaian bahan plastik untuk karung. Tahun 2004, rosella muncul dan terkenal lagi. Pemunculan ini rupanya terkait dengan warna bunganya yang merah. Di kalangan herbalis, warna merah bukan cuma berarti berani tapi sering dikaitkan dengan khasiat untuk mengobati penyakit.

Tak salah kalau orang menyebutnya sebagai bunga rosella. Memang yang dijadikan minuman bukan keseluruhan bunga, tapi cuma kelopaknya. Kelopak inilah yang mengandung vitamin $\mathrm{C}$ tinggi. Bahkan kandungannya sembilan kali lebih banyak dibandingkan dengan vitamin $\mathrm{C}$ di dalam jeruk sitrus dan sepuluh kali lipat dibandingkan dengan belimbing. Setiap $100 \mathrm{~g}$ kelopak rosella segar mengandung $260-280 \mathrm{mg}$ vitamin C. Jumlah itu tiga kali lipat kadar vitamin pada anggur hitam. Seperti kita tahu, di dalam tubuh, vitamin $\mathrm{C}$ alami ini berfungsi membantu memperbaiki metabolisme dan meningkatkan daya tahan tubuh.

Kelopak bunga rosella juga kaya vitamin A, kalsium, kalium, zat besi, natrium, karbohidrat, serat, dan zat-zat gizi lain. Kombinasi dari beberapa jenis nutrisi ini digunakan oleh para herbalis untuk membuat resep menurunkan lemak badan. Juga program diet buat penderita kencing manis dan mencegah osteoporosis.

Di sejumlah negara di Afrika, India, dan Meksiko, rosella dikategorikan sebagai obat tradisional. Kira-kira seperti jamu di Indonesia. Ekstrak kelopak bunga rosella berkhasiat antikejang, anticacing, antibakteri, bahkan bisa mematikan mycobacterium tuberculosis, kuman penyebab tuberkulosis. Khasiat lain adalah sebagai penetral alkohol. Uji praklinik pada unggas menunjukkan bahwa ekstrak rosella menurunkan tingkat penyerapan alkohol sehingga menurunkan efek alkohol di dalam tubuh. Di Guatemala malah jadi salah satu obat terapi pecandu narkoba.

Sumber: Intisari, Agustus 2009, hlm. 104-110

Pilihlah satu jawaban berikut yang menurut Anda benar dengan menyilang huruf $A, B, C$, atau D.

Mengapa nama rosella menarik perhatian? Karena...

(A) khasiatnya mengusir berbagai keluhan tubuh.

(B) warna bunganya merah cabai.

(C) dapat digunakan untuk pembuatan karung dan pakaian.

(D) rasanya yang asem-asem segar.

Pada contoh di atas empat opsi jawaban yang tercantum dalam bacaan adalah opsi (A) khasiatnya mengusir berbagai keluhan tubuh. Hal tersebut dapat dilihat dari bentuk pertanyaannya yang menggunakan kata tanya "mengapa" dan jawaban yang tercantum dalam bacaan adalah khasiatnya mengusir berbagai keluhan tubuh, yaitu pada kutipan bacaan berikut.

Nama rosella tiba-tiba menarik perhatian, tentu karena khasiatnya mengusir berbagai keluhan tubuh. Mulai dari yang ringan seperti menjaga stamina, menurunkan panas, menurunkan tekanan darah, sampai yang lumayan berat seperti menurunkan kadar gula, menghambat tumbuhnya kanker, atau memulihkan ketergantungan obat.

\section{How}

Kata tanya how 'bagaimana'berisi pertanyaan-pertanyaan yang mengandung cara atau proses berlangsungnya suatu peristiwa. Kata tanya ini sama dengan kata 
tanya why 'mengapa', yaitu tidak selamanya penggunaan kata tanya ini menghasilkan soal yang bersifat faktual. Soal dikatakan bersifat faktual jika opsi jawaban tertera atau eksplisit di dalam bacaan. Contoh pertanyaan yang menggunakan kata tanya how 'bagaimana'. Bagaimana peristiwa itu bisa terjadi? Bagaimana dia melakukan perbuatan itu? Bagaimana dia bertemu dengannya pertama kali? Bagaimana cara memecahkan masalah ini? Bagaimana dia menyelesaikan semua pekerjaannya?

\section{Bacalah bacaan berikut! "RACUNKELUAR SAAT BERPUASA"}

Proses detoksifikasi tidak sederhana. Ada lima tahapan yang berlangsung dalam 40 hari. Tahap pertama berlangsung dua hari. Pada tahap ini kadar gula darah turun sampai di bawah 70 $\mathrm{mg} / \mathrm{dl}$. Untuk menutup kekurangan, glikogen dari lever diubah menjadi glukosa. Glikogen juga diambil dari otot sehingga tubuh menjadi lemas. Untuk menghemat enegi, basal metabolic rate (BMR) diturunkan sehingga denyut jantung melambat dan tekanan darah turun. Healing crisis terjadi pada tahap ini: sakit kepala, pusing, mual, napas bau, mata berkabut, dan lidah yang terasa tebal. Tahap ini mungkin ditandai dengan rasa lapar yang kuat.

Tahap kedua berlangsung mulai hari ke-3 sampai ke-7. Tubuh mulai menyesuaikan diri. Sistem pencernaan istirahat. Energi dipusatkan untuk pembersihan dan pemulihan. Lemak diurai untuk melepas gliserol yang diubah menjadi glukosa. Oksidasi lemak menghasilkan keton-keton yang menekan selera makan. Mungkin muncul jerawat atau bisul karena lemak-lemak rusak mulai dikeluarkan dari tubuh. Organ-organ pembersih mulai diperbaiki, termasuk paru-paru. Jadi, kalau paru-paru terasa nyeri, tidak perlu merasa takut. Perbaikan juga menyentuh usus besar. Plak pada dindingnya mulai melunak dan lepas. Napas masih bau dan lidah terasa tebal.

Seminggu kemudian merupakan tahap ketiga. Tahap ini ditandai dengan peningkatan energi, pikiran yang lebih jernih, dan tubuh yang terasa lebih fit. Luka lama mungkin terasa nyeri kembali karena daya sembuh dari tubuh yang meningkat. Sel-sel darah putih mengeluarkan zat yang dapat melarutkan sel-sel mati. Zat inilah yang menimbulkan rasa nyeri pada syaraf di sekitar bekas luka. Nyeri ini menjadi penanda bahwa proses penyembuhan hampir berakhir. Nyeri (dan tegang) juga terasa pada otot karena iritasi toksin, terutama di kaki tempat toksin terkumpul. Persoalan lain ialah munculnya sariawan karena bakteri yang berlebihan di mulut. Atasilah dengan berkumur air garam.

Sisa hari sampai tahap detoksifikasi selesai merupakan tahap keempat. Tubuh sudah beradaptasi sehingga energi meningkat. Pikiran yang lebih jernih terasa setelah hari ke-20. Emosi menjadi stabil; daya ingat dan konsentrasi meningkat. Kerja tubuh dalam mengganti sel-sel yang rusak maksimum. Keseimbangan homeostatik mencapai tingkat optimal. Sistem getah bening sudah bersih, tapi lendir mungkin masih keluar melalui hidung dan tenggorokan. Napas sudah normal. Jadi, rasa percaya diri sudah kembali.

Tahap kelima ialah buka puasa. Saat berbuka, makanan yang masuk akan melepaskan plak pada dinding usus yang sudah melunak. Toksin masuk ke darah dan keluar dari tubuh melalui usus besar. Empedu membuang ampasnya melalui cairan empedu dalam jumlah yang besar. Mungkin dengan diikuti diare. Jika tak nyaman, bisa dibantu dengan colon hydrotherapy.

Sumber: Intisari, No. 543, Oktober 2008, hlm. 52 
Pilihlah satu jawaban berikut yang menurut Anda benar dengan menyilang huruf A, B, C, atau D.

Bagaimana proses detoksifikasi tahap

kelima berlangsung?

(A) Tubuh sudah beradaptasi sehingga energi meningkat. Pikiran yang lebih jernih terasa setelah hari ke20. Emosi menjadi stabil; daya ingat dan konsentrasi meningkat. Kerja tubuh dalam mengganti selsel yang rusak maksimum. Keseimbangan homeostatik mencapai tingkat optimal. Sistem getah bening sudah bersih, tapi lendir mungkin masih keluar melalui hidung dan tenggorokan.

(B) Saat berbuka, makanan yang masuk akan melepaskan plak pada dinding usus yang sudah melunak. Toksin masuk ke darah dan keluar dari tubuh melalui usus besar. Empedu membuang ampasnya melalui cairan empedu dalam jumlah yang besar. Mungkin dengan diikuti diare

(C) Tubuh mulai menyesuaikan diri. Sistem pencernaan istirahat. Energi dipusatkan untuk pembersihan dan pemulihan. Lemak diurai untuk melepas gliserol yang diubah menjadi glukosa. Oksidasi lemak menghasilkan keton-keton yang menekan selera makan. Mungkin muncul jerawat atau bisul karena lemak-lemak rusak mulai dikeluarkan dari tubuh. Organorgan pembersih mulai diperbaiki, termasuk.

(D) paru-paru.

(E) Pada tahap ini kadar gula darah turun sampai di bawah $70 \mathrm{mg} / \mathrm{dl}$. Untuk menutup kekurangan, glikogen dari lever diubah menjadi glukosa. Glikogen juga diambil dari otot sehingga tubuh menjadi lemas. Untuk menghemat enegi, basal metabolic rate (BMR) diturunkan sehingga denyut jantung melambat dan tekanan darah turun.

Pada contoh di atas empat opsi jawaban yang tercantum dalam bacaan adalah opsi (B) Saat berbuka, makanan yang masuk akan melepaskan plak pada dinding usus yang sudah melunak. Toksin masuk ke darah dan keluar dari tubuh melalui usus besar. Empedu membuang ampasnya melalui cairan empedu dalam jumlah yang besar. Mungkin dengan diikuti diare. Hal tersebut dapat dilihat dari bentuk pertanyaannya yang menggunakan kata tanya "bagaimana" dan jawaban yang tercantum pada kutipan bacaan berikut.

Tahap kelima ialah buka puasa. Saat berbuka, makanan yang masuk akan melepaskan plak pada dinding usus yang sudah melunak. Toksin masuk ke darah dan keluar dari tubuh melalui usus besar. Empedu membuang ampasnya melalui cairan empedu dalam jumlah yang besar. Mungkin dengan diikuti diare. Jika tak nyaman, bisa dibantu dengan colon hydrotherapy.

\section{PENUTUP}

Kemampuan jawab guru SLTP dan SLTA di DIY dalam menjawab soal yang bersifat faktual masing-masing adalah $81 \%$. Berdasar sifat soal faktual strategi yang dapat digunakan untuk menjawab bentuk penyoalan ini adalah dengan menggunakan strategi $5 \mathrm{~W} 1 \mathrm{H}$, yaitu who, what, where, when, why, dan how. Strategi ini dapat dijabarkan sebagai berikut. Who ialah tentang siapa? What, apa yang terjadi? Where, di mana peristiwa itu terjadi, when, kapan hal itu terjadi? Why, mengapa hal itu terjadi? How, bagaimana hal itu terjadi?

\section{DAFTAR PUSTAKA}

Maryanto. 2009. "Format Penyusunan Soal UKBI" (hand out). Jakarta: Badan Pengembangan dan Pembinaan 
Totobuang, Vol. 6, No. 1, Juni 2018: 139-154

Bahasa, Kementerian Pendidikan dan Kebudayaan.

Solihah, Atikah. 2014. "Evaluasi Kebijakan Uji Kemahiran Berbahasa Indonesia (UKBI)". Jakarta: Badan Pengembangan dan Pembinaan Bahasa, Kementerian Pendidikan dan Kebudayaan.

-2014. "Penyusunan

Soal UKBI" (hand out, PPT).

Jakarta: Pusat Pengembangan dan PelindunganBadan

Pengembangan dan Pembinaan

Bahasa.
Sudaryanto. 1993. Metode dan Aneka

Teknik Analisis Bahasa:

Pengantar Penelitian Wahana

Kebudayaan Secara Linguistis.

Yogyakarta: Duta Wacana

University Press.

\section{SUMBER DATA}

Intisari, Oktober 2008, hlm. 42

Intisari, Oktober 2008, hlm. 52

Intisari, Agustus 2009, hlm. 104-110 


\begin{tabular}{|lcc|}
\hline \multicolumn{3}{|c|}{ TOTOBUANG } \\
\hline Volume 6 & Nomor 1, Juni 2018 & Halaman $155-167$ \\
\hline
\end{tabular}

\title{
RELASI KEKERABATAN BAHASA HITU, WAKAL, MORELA, MAMALA, DAN HILA DI PROVINSI MALUKU \\ (The Family Relationship Language Hitu, Wakal, Morela, Mamala, and Hila in Maluku Province)
}

\author{
Taufik \\ Universitas Iqra Buru \\ Jl. Prof. Dr. H. A.R. Basalamah No. 20, Namlea, Buru \\ Pos-el: taufiksalamun@gmail.com
}

(Diterima: 19 April 2018; Direvisi: 30 Mei 2018; Disetujui: 04 Juni 2018)

\begin{abstract}
This study aimed to describe the cognate words based on the determined criterion of relative word and determine the percentage of kinship towords Hitu, Wakal, Morela, Mamala, and Hila language. This study used descriptive qualitative and quantitative approach. The data were collected through interview techniques and field note method. The data that had been obtained were classified and described qualitatively and quantitatively by using calculational lexicostatistic formula. The results showed that the pair of relative word in the language of Hitu, Wakal, Morela, Mamala, and Hila could be reviewed by the pairs of identical, correspondences phonemic, phonetic resemblance, a different phoneme, and deleted phonemes. Based on the calculational lexicostatistic, the percentage of Hitu-Hila language kinship was in the highest level of kinship, which wa $90 \%$ and had been categorized as a dialect. While the lowest percentage of kinship wasWakal-Morela with the percentage of kinship about $77 \%$ and had been categorized as sub-family language.

Keywords: phonemes, kinship percentage, lexicostatistics
\end{abstract}

\section{Abstrak}

Penelitian ini bertujuan untuk mendeskripsikan kata-kata kognat berdasarkan kriteria penentuan kata kerabat dan menentukan tingkat persentase kekerabatan bahasa Hitu, Wakal, Morela, Mamala, dan Hila. Jenis penelitian ini bersifat deskriptif dengan pendekatan kualitatif dan kuantitatif. Data dikumpulkan melalui metode pupuan lapangan dengan teknik wawancara dan catat. Data yang telah diperoleh kemudian diklasifikasi dan selanjutnya dideskripsikan secara kualitatif dan kuantitatif dengan menggunakan rumus perhitungan leksikostatistik. Hasil penelitian menunjukkan bahwa pasangan kata kerabat pada bahasa Hitu, Wakal, Morela, Mamala, dan Hila dapat ditinjau berdasarkan pasangan kata identik, korespondensi fonemis, kemiripan secara fonetis, satu fonem beda, dan pelesapan fonem. Berdasarkan perhitungan leksikostatistik, persentase kekerabatan bahasa Hitu-Hila menduduki tingkat kekerabatan tertinggi, yaitu 90\% dan dikategorikan sebagai satu bahasa dialek. Sedangkan persentase kekerabatan terendah, yaitu bahasa Wakal-Morela dengan persentase kekerabatan sebesar 77\% dan dikategorikan sebagai subkeluarga bahasa.

Kata-kata kunci: fonem, persentase kekerabatan, leksikostatistik

\section{PENDAHULUAN}

Bahasa dapat mengatur berbagai macam aktivitas kemasyarakatan, merencanakan dan mengarahkan masa depan seseorang. Meskipun kita tahu bahwa masih ada alat komunikasi lain seperti gerak tubuh, bunyi-bunyian, lukisan-lukisan, dan semacamnya, tetapi bahasa merupakan alat komunikasi yang lebih tepat dan efektif.
Hal di atas membuktikan bahwa bahasa memiliki peranan yang penting bagi kehidupan manusia. Begitu pentingnya bahasa (Taufik, 2017) menyatakan bahwa ketika seorang pembicara menggunakan bahasa yang tidak dipahami dalam komunikasi maka pesan yang disampaikan oleh pembicara tidak akan sampai kepada pendengar. Hal tersebut Sesuai dengan pendapat Keraf (2004) yang menuturkan 
bahwa bahasa merupakan saluran perumusan maksud kita, melahirkan perasaan kita dan memungkinkan kita menciptakan kerja sama dengan sesama warga. Begitupula dengan bahasa-bahasa yang tersebar di seluruh wilayah nusantara.

Hampir setiap daerah yang ada di Indonesia memiliki bahasa daerah dan dialeknya sendiri. Bahasa dan dialek tersebut digunakan untuk berkomunikasi antarsesama masyarakat di tiap daerah tersebut. Oleh sebab itu, bahasa dapat dijadikan sebagai salah satu ciri yang menunjukkan identitas suatu bangsa atau daerah. Melalui bahasa, orang dapat mengidentifikasi kelompok masyarakat tertentu, mengenali perilaku, dan kepribadian masyarakat penuturnya, serta mengenali budayanya.

Berkaitan dengan hal di atas, Alijah (2016) menyatakan bahwa bahasa-bahasa daerah ini merupakan salah satu unsur kebudayaan Indonesia yang perlu terus dipelihara dan dilestarikan. Hal ini sesuai dengan UUD Republik Indonesia Nomor 24 tahun 2009 Pasal 1 ayat 6 yang berbunyi: "Bahasa daerah adalah bahasa yang digunakan secara turun temurun oleh warga Indonesia di daerah-daerah di wilayah Negara Kesatuan Republik Indonesia”. Oleh sebab itu, negara dan warganya wajib memelihara, mengembangkan, dan melestarikan bahasa-bahasa daerah agar nilai-nilai budaya yang terkandung didalamnya tetap utuh dan tetap memainkan perannya sebagai salah satu aset kebudayaan nasional.

Alwi dan Sugono (dalam Simon, 2015) menyatakan bahwa bahasa daerah adalah bahasa yang dipakai sebagai bahasa perhubungan intradaerah atau intramasyarakat selain bahasa Indonesia yang dipakai sebagai sarana pendukung sastra serta budaya daerah atau masyarakat etnik di wilayah Republik Indonesia. Demikian juga dengan masyarakat pemakai bahasa Hitu, Wakal, Morela, Mamala, dan Hilayang tersebardi wilayah Jazirah Leihitu, Kabupaten Maluku Tengah, Provinsi
Maluku yang menggunakan bahasa daerahnya dalam berkomunikasi antarpemakai bahasa yang sama.

Bahasa-bahasa daerah di atas merupakan bahasa yang terdapat pada desa atau negeri yang secara geografis letaknya saling berdekatan, yakni Negeri Hitu, Wakal, Morela, Mamala, dan Hila. Kedekatan negeri-negeri tersebut memungkinkan adanya kontak bahasa dan budaya sehingga dapat saling memengaruhi. Hal itu memungkinkan adanya persamaan antarbahasa-bahasa di atas, utamanya dalam bidang fonologi dan leksikon. Dalam bidang fonologi persamaan tersebut dapat berupa cara artikulasi, misalnya kata jalan. Kata ini pada bahasa Hitu memiliki bentuk lalan dan pada bahasa Mamala memiliki bentuk lalay. Kedua kata tersebut memiliki fonem akhir yang berbeda, yaitu $/ \mathrm{n} / \mathrm{dan} / \mathrm{y} /$. Meskipun berbeda, namun kedua fonem tersebut samasama berada pada posisi artikulasi yang sama, yaitu nasal. Sementara itu, dalam bidang leksikon terdapat bentuk yang sama, misalnya kata berjalan. Kata ini pada bahasa Wakal, Hitu, dan Morela memiliki bentuk leksikon yang sama, yaitu oi.

Menurut Sudarno (1994) hampir semua bahasa di Indonesia memiliki kesamaan atau kemiripan bentuk dan makna antarsatu bahasa dengan bahasa yang lain. Hal ini menunjukkan adanya hubungan atau relasi antarbahasa-bahasa yang dipakai pada desa-desa yang saling berdekatan. Oleh sebab itu, analisis kualitatif dengan jalan pendeskripsian fenomena kebahasaan dan analisis kuantitatif dalam linguistik komparatif dilakukan dengan menerapkan teknik leksikostatistik untuk melihat relasi kekerabatan bahasa Hitu, Wakal, Morela, Mamala, dan Hila. Johnson (2008) mendeskripsikan metode analisis kuantitatif dengan teknik leksikostatistik yang digunakan dalam kajian linguistik diakronis dengan 200 kosakata dasar Swadesh sebagai ukuran dari keseluruhan kosakata bahasa yang dikaji. Teknik leksikostatistik merupakan teknik sederhana yang secara 
statistik untuk memperkirakan derajat perbedaan linguistik antara bahasa-bahasa berkerabat (Trask, 2000).

Pemetaan tingkat kekerabatan tersebut merupakan gambaran sebagian besar kehidupan sosial dan budaya masyarakat Maluku yang multilingual, yang secara pasti menimbulkan situasi kebahasaan yang sedikit rumit. Oleh sebab itu, melalui penelitian ini penulis mencoba memecahkan masalah tersebut dengan menentukan status (bahasa, dialek, dan subdialek) antara bahasa Hitu, Wakal, Morela, Mamala, dan Hila dengan mendeskripsikan kata-kata kognat yang berdasarkan pada kriteria penentuan kata-kata kerabat. Tahap selanjutnya adalah menentukan tingkat persentase bahasabahasa tersebut. Pengamatan kedua hal itu akan dilakukan dengan pendekatan leksikostatistik sebagai salah satu metode pengelompokan bahasa yang lebih awal, cepat, hemat, dan handal (Langgole, 1997).

Selanjutnya, dari penelitian ini diharapkan dapat menjadi salah satu sumber informasi pada bidang kebahasaan, terutama yang ada kaitannya dengan bidang pengelompokan bahasa-bahasa tertentu yang ada di Provinsi Maluku.Hasil penelitian ini juga diharapkan dapat dijadikan sebagai bahan masukan bagi pihak-pihak yang berwenang dalam bidang pembinaan dan pengembangan bahasa untuk menyusun strategi pengembangan dan pembinaan bahasa di masa mendatang.

\section{LANDASAN TEORI}

Salah satu bidang ilmu yang mempersoalkan keadaan atau kondisi bahasa-bahasa di dunia adalah Linguistik Historis Komparatif (LHK). Keraf (1996) mengatakan bahwa Linguistik Bandingan Historis (Linguistik Historis Komparatif) adalah salah satu cabang dari ilmu bahasa yang mempersoalkan bahasa dalam bidang waktu serta perubahan-perubahan unsur bahasa yang terjadi dalam bidang waktu tersebut. Salah satu kepentingan Linguistik Historis Komparatif adalah mengadakan pengelompokkan (sub-grouping) bahasabahasa dalam suatu rumpun bahasa. Bahasa dalam satu rumpun sama belum tentu sama pada tingkat kekerabatan atau sama tingkat kemiripannya satu sama lain.

Kridalaksana (2008) menuturkan bahwa kekerabatan adalah hubungan antara dua bahasa atau lebih yang diturunkan dari sumber bahasa induk yang sama atau yang biasa disebut bahasa purba. Bahasa berkerabat adalah bahasa yang memiliki hubungan antara bahasa yang satu dengan yang lain. Hubungan ini bisa jadi merupakan asal atau induk yang sama sehingga terdapat kemiripan atau karena adanya ciri-ciri umum yang sama. Dalam hal bahasa kemiripan itu terlihat dari segi fonologi, morfologi, dan sintaksis.

Lebih lanjut Keraf (1996) menambahkan bahwa bahasa-bahasa kerabat yang berasal dari proto yang sama selalu akan memperlihatkan kesamaan-kesamaan berikut:

1. Kesamaan sistem bunyi (fonetik) dan susunan bunyi (fonologis);

2. Kesamaan morfologis, yaitu kesamaan dalam bentuk kata dan kesamaan dalam bentuk gramatikal;

3. Kesamaan sintaksis, yaitu kesamaan relasinya antara kata-kata dalam sebuah kalimat.

Dalam membandingkan dua bahasa atau lebih dapat digunakan teknik leksikostatistik, yaitu salah satu metode pengelompokan bahasa yang banyak dipakai oleh para pakar atau peneliti bahasa di dunia. Menurut Sulistyono (2015) teknik leksikostatistik merupakan salah satu alat analisis dalam penelusuran linguistis yang memanfaatkan metode komparatif. Metode pengelompokan ini mengamati hubungan kekerabatan dua bahasa atau lebih yang berdasarkan pada kosakatanya. Selanjutnya dari kosakata yang berkerabat tersebut dituangkan dalam bentuk statistik yang berupa angka-angka.

Menurut Wacana

leksikostatistik adalah suatu teknik dalam 
pengelompokan bahasa yang lebih cenderung dan lebih mengutamakan peneropongan kata-kata (leksikon) secara statistik, untuk kemudian berusaha menetapkan pengelompokan itu berdasarkan persentase kesamaan dan perbedaan suatu bahasa dengan bahasa lain. Sejalan dengan itu, menurut Nothofer (1990) penentuan tingkat kekerabatan bahasa-bahasa yang dianalisis dengan menggunakan metode leksikostatistik memiliki beberapa keunggulan jika dibandingkan dengan metode-metode lain. Keunggulankeunggulan tersebut, yaitu (1) sebagai daftar kosakata dasar yang cepat dapat menentukan hubungan kekerabatan bahasa yang kerabat, (2) sebagai alat pengelompokan bahasa (dialek) yang sekerabat yang proto bahasanya belum begitu tua (kuno), dan (3) sebagai alat (metode) yang dapat dipakai pada tahap awal menetapkan klasifikasi bahasa.

Penetapan kosakata kerabat dapat dilakukan dengan prosedur sebagai berikut:

a. Jika sebuah kata terdapat morfem terikat, morfem tersebut harus dipisahkan, kemudian baru dibandingkan kemiripan atau kesamaannya.

b. Penetapan kosakata kerabat dapat dilakukan dengan kriteria: (1) pasangan kosakata itu identik, (2) pasangan kosakata itu berkorespondensi fonemis, (3) adanya kemiripan secara fonetis, (4) satu fonem berbeda, (5) pelesapan fonem.

c. Penyusunan matriks persentase kekerabatan untuk mempermudah penentuan sub grouping mikro, hasil perhitungan kosakata kerabat dimasukan dalam matriks.

Secara garis besar leksikostatistik memiliki tiga asumsi/pendirian dasar, yaitu (1) kosakata dasar diganti dengan kecepatan yang sama pada semua bahasa pada waktu yang sama. Asumsi ini beranggapan bahwa setiap 1000 tahun atau sekitar 18-20\% kosakata dasar berubah pada semua bahasa secara serentak, (2) semua kosakata dasar yang terdapat pada daftar kosakata dasar kemungkinan kata-kata itu terganti secara serentak, dan (3) ada yang disebut kosakata dasar yang dianggap berlaku umum pada semua bahasa (Nothofer, 1990).

Menurut Surbakti (2014) dalam membandingkan kata-kata untuk menetapkan kata-kata mana yang merupakan kata kerabat dan mana yang tidak, maka perlu dikemukakan lagi suatu asumsi lain dalam metode perbandingan, yaitu: fonem bahasa proto yang sudah berkembang secara berlainan dalam bahasa-bahasa kerabat, akan berkembang terus secara konsisten dalamlingkungan linguististiap-tiap bahasa kerabat. Oleh sebab itu, penetapan kosakata yang dianggap kognat perlu mempertimbangkan kemungkinan adanya kosakata yang merupakan pinjaman dari bahasa-bahasa lain, misalnya bahasa Melayu dan bahasa-bahasa lain yang berpengaruh di lokasi sekitar, seperti bahasa Belanda dan Portugis.Selain itu, harus mempertimbangkan kata-kata yang merupakan tiruan bunyi (onomatope), kata bayi (nursery words), dan kata-kata yang kebetulan mirip dalam penetapan status kekognatan kata, sehingga didapatlah katakata yang kognat.

Jumlah kosakata yang kognat tersebutdapat menentukan persentase tingkat kekerabatan antara bahasa-bahasa yang dibandingkan. Penentuan tersebut dilakukan berdasarkan perhitungan dengan menggunakan rumus dalam leksikostatistik, yaitu rumus untuk mencari tingkat persentase hubungan kekerabatan bahasabahasa yang dianalisis. Setelah diperoleh persentase kekerabatan, status kekerabatan antarbahasa ditentukan sesuai dengan kriteria penetapan relasi genetis antarbahasa yang dikemukakan oleh Crowley (2010). 
Tabel 1

Pembagian Tingkatan Persentase Kekerabatan Antarbahasa

\begin{tabular}{|l|l|}
\hline \multicolumn{1}{|c|}{ Level Pengelompokan } & \multicolumn{1}{c|}{ PersentaseKognat } \\
\hline Bahasa Dialek (dialect of language) & $81-100 \%$ \\
\hline Subkeluarga Bahasa (Language of Subfamily) & $61-81 \%$ \\
\hline Keluarga Bahasa (Language of family) & $36-81 \%$ \\
\hline Keturunan Keluarga Bahasa (Family of stock) & $12-36 \%$ \\
\hline Keturunan Mikrofilium (stock of Microphylum) & $4-12 \%$ \\
\hline Mesofilium & $1-4 \%$ \\
\hline Makrofilium & $0-1 \%$ \\
\hline
\end{tabular}

Berdasarkan tabel pengelompokan bahasa di atas,hubungan kekerabatan antarbahasa dapat diketahui melalui perhitungan persentase kekerabatan. Persentase kekerabatan antarbahasa tersebut dapat dijadikan acuan dalam pengelompokan bahasa Hitu, Wakal, Morela, Mamala, dan Hila.

\section{METODE PENELITIAN \\ Jenis Penelitian dan Pendekatan}

Penelitian ini merupakan penelitian deskriptif dengan pendekatan kualitatif dan kuantitatif.Pendekatan kualitatif digunakan untuk menjelaskan fenomena kebahasaan berdasarkan pada kriteria penentuan kata kerabat. Sementara itu, pendekatan kuantitatif digunakan untuk menentukan persentase kekerabatan bahasa Hitu, Wakal, Morela, Mamala, dan Hila dengan menerapkan rumus perhitungan leksikostatistik.

\section{Metode dan Teknik Pengumpulan Data}

Metode pengumpulan data yang dipakai pada penelitian ini adalah metode pupuan lapangan (metode lapangan langsung). Teknik yang dapat digunakan untuk menunjang metode pupuan lapangan adalah teknik wawancara dan catat. Dalam penelitian ini digunakan 200 daftar kosakata dasar Morris Swadesh sebagai instrumen penelitian. Selanjutnya, kata-kata tersebut ditanyakan kepada informan tiap-tiap bahasa yang dianalisis, yaitu bahasa Hitu, Wakal, Morela, Mamala, dan Hila. Pemilihan informan penelitian berdasarkan pada kriteria: (1) penutur asli dari bahasa yang diteliti, (2) berdomisili pada lokasi penelitian, (3) tidak memiliki cacat pada artikulasinya, (4) berusia antara 30-60 tahun, (5) memiliki waktu yang cukup untuk menjawab setiap pertanyaan (Djajasudarma dalam Wahyu, 2013).Hasil dari pengumpulan tersebut selanjutnya dijadikan sebagai data penelitian.

\section{Teknik Analisis Data}

Data yang telah diperoleh melalui wawancara, dianalisis melalui tahap, mengidentifikasi kata-kata yang kognat, mengklasifikasi data berdasarkan kriteria penentuan kata kerabat yang terdiri atas kata identik, korespondensi fonemis, kemiripan secara fonetis, dan pelesapan fonem. Data yang telah diklasifikasi, dideskripsikan berdasarkan kriteria penentuan kekerabatan tersebut. Melalui hasil deskripsi akan diperoleh jumlah kata kognat dari tiap-tiap bahasa yang dianalisis, yakni bahasa Hitu, Wakal, Morela, Mamala, dan Hila.

Setelah diperoleh jumlah kata kognat, tahap selanjutnya adalahdata dianalisis dengan menggunakan metode leksikostatistik. Teknik ini memakai angkaangka sebagai dasar pemilihannya. Untuk menghitung persentase kata kognat dapat digunakan rumus berikut ini.

$$
\mathrm{c}=\frac{\mathrm{g}}{\mathrm{n}} \times 100 \%
$$


keterangan:

$$
\begin{aligned}
& \mathrm{C}=\text { Persentase kerabat } \\
& \mathrm{g}=\text { Jumlah kata kognat } \\
& \mathrm{n}=\text { Total glos }
\end{aligned}
$$

\section{PEMBAHASAN}

Berdasarkan pada pemerolehan data maka dapat dideskripsikan kata-kata kerabat bahasa Hitu, Wakal, Morela, Mamala, dan Hila berdasarkan empat kriteria penentuan kata kerabat yang dikemukakan oleh Keraf
(1996). Selanjutnya dari hasil penentuan kriteria tersebut dapat ditentukan tingkat persentase bahasa-bahasa yang dianalisis. Berikut hasil analisis kekerabatan bahasa Hitu, Wakal, Morela, Mamala, dan Hila.

\section{Kata Identik}

Pasangan kata dikatakan identik apabila semua fonem dari pasangan kata tersebut sama betul. Berikut pasangan kata pada bahasa Hitu, Wakal, Morela, Mamala, dan Hila yang memiliki pasangan kata identik.

Tabel 2

Pasangan Kata Identik

\begin{tabular}{|c|c|c|c|c|c|}
\hline Gloss & Hitu & Wakal & Morela & Mamala & Hila \\
\hline datang & lai & lai & lai & lai & lai \\
\hline jauh & lau & lau & lau & lau & lau \\
\hline engkau & ale & ale & ale & ale & ale \\
\hline merah & kau & kau & kau & kau & kau \\
\hline rambut & keul & keul & keul & keul & keul \\
\hline
\end{tabular}

Pada tabel 2 tampak bahwa dari kelima bahasa yang dianalisis, kata-kata tersebut memiliki fonem dan urutan yang sama atau identik. Hal itu dapat dilihat pada kata datang. Kata ini pada bahasa Hitu, Wakal, Morela, Mamala, dan Hila memiliki bentuk yang sama, yaitu lai yang terdiri atas susunan /l/, /a/, /i/. Selanjutnya kata jauh pada kelima bahasa yang dianalisis tersebut memiliki bentuk yang sama atau identik, yaitu lau yang terdiri atas susunan /l/, /a/, /u/. Kata selanjutnya yang bentuknyasama atau identikdari kelima bahasa yang dianalisis adalah kata engkau yang dalam kelima bahasa tersebut sama-sama memiliki bentuk ale yang terdiri atas susunan /a/, /l/, /e/. Kata lainnya yang bentuknyasama atau identikdari kelima bahasa tersebut adalah kata merah. Kata ini dalam kelima bahasa itu sama-sama memiliki bentuk kau yang terdiri atas susunan /k/, /a/, /u/. Kata selanjutnya yang samaatau identik dari tabel 2 pada bahasa Hitu, Wakal, Morela, Mamala, dan Hila adalah rambut. Kata ini pada kelima bahasa tersebut memiliki bentuk yang sama, yaitu keul yang terdiri atas susunan /k/, /e/, /u/, /l/.

\section{Korespondensi Fonemis}

Bila perubahan fonem antara pasangan kata itu terjadi secara timbal-balik dan teratur, serta besar frekuensinya, bentuk yang berimbang antara pasangan kata tersebut dianggap berkerabat. Berikut pasangan kata pada bahasa Hitu, Wakal, Morela, Mamala, dan Hila yang berkorespondensi fonemis.

Tabel 3

Pasangan Kata yang Berkorespondensi Fonemis

\begin{tabular}{|c|c|c|c|c|c|}
\hline Gloss & Hitu & Wakal & Morela & Mamala & Hila \\
\hline beberapa & yi:la & i:la & yi:la & wai:la & waila \\
\hline tahu & kewa & ke:wa & kewan & tewa & kewa \\
\hline
\end{tabular}




\begin{tabular}{|c|c|c|c|c|c|}
\hline duduk & ko:lo & kolo & ko:lo & tolo & kolo \\
\hline mereka & sile & sile & yile & sile & sile \\
\hline air bah & henel & henel & henen & henen & henel \\
\hline
\end{tabular}

Kata pada tabel 3 yang mengalami korespondensi fonem adalah kata beberapa. Kata ini pada bahasa Hitu dan Morela memiliki bentuk yang sama, yaitu yi:layang terdiri atas susunan/y/, /i/, ///, /a/. Kata yila mengalami korespondensi fonem pada bahasa Mamala dan Hila menjadi waila yang terdiri atas susunan /w/, /a/, /i/, /l/, /a/. Korespondensi yang terjadi yaitu /y/ pada bahasa Hitu-Morela berkorespondensi dengan /wa/ pada bahasa Mamala dan Hila. Sedangkan pada bahasa Wakal kata yila dan waila mengalami pelesapan fonem menjadi ila yang terdiri atas susunan /i/, /1/, /a/.

Selanjutnya kata yang mengalami korespondensi fonem pada tabel 3 tampak pada kata tahu. Kata tersebut memiliki bentuk yang sama pada bahasa Hitu, Wakal, dan Hila, yakni kewayang terdiri atas susunan/k/, /e/, /w/, /a/. Sementara itu, kata kewa pada bahasa Morela mendapat penambahan $/ \mathrm{y} /$ di akhir kata menjadi kewayyang terdiri atas susunan /k/, /e/, /w/, /a/, /y/. Kata kewa mengalami korespondensi fonem pada bahasa Mamala menjadi tewa yang terdiri atas susunan $/ \mathrm{t} / \mathrm{h} / \mathrm{e} / \mathrm{,} / \mathrm{w} / \mathrm{l} / \mathrm{a} /$. Berdasarkan penjabaran tersebut korespondensi yang terjadi, yaitu /k/ pada bahasa Hitu, Wakal, Hila, dan Morela berkorespondensi dengan /t/ pada bahasa Mamala.

Kata lainnya yang mengalami korespondensi fonem pada tabel 3 tampak pada kata duduk. Kata tersebut memiliki bentuk yang sama pada bahasa Hitu, Wakal, Morela, dan Hila, yaitu kolo yang terdiri atas susunan/k/, /o/, /l/, /o/. Sementara itu, kata kolo mengalami korespondensi fonem di awal kata pada bahasa Mamala menjadi tolo yang terdiri atas susunan $/ \mathrm{t} /, / \mathrm{o} /, / \mathrm{l} /, \mathrm{lo} /$. Berdasarkan penjabaran tersebut korespondensi yang terjadi, yaitu $/ \mathrm{k} /$ pada bahasa Hitu, Wakal, Hila, dan Morela berkorespondensi dengan /t/ pada bahasa Mamala.

Pada tabel 3, kata lainnya yang mengalami korespondensi fonem adalah kata mereka. Kata ini pada bahasa Hitu, Wakal, Mamala, dan Hila memiliki bentuk yang sama, yaitu sile yang terdiri atas susunan fonem /s/, /i/, /l/, /e/. Pada bahasa Morela kata sile mengalami korespondensi fonemis di awal kata menjadi yile yang terdiri atas susunan fonem /y/, /i/, /l/, /e/. Korespondensi yang terjadi pada kelima bahasa tersebut adalah /s/ pada kata sile berkorespondensi dengan /y/ pada kata yile.

Kata berikutnya yang mengalami korespondensi fonem adalah kata air bah. Kata ini pada bahasa Hitu, Wakal, dan Hila memiliki bentuk yang sama, yaitu henel yang terdiri atas susunan $/ \mathrm{h} /, / \mathrm{e} /, \mathrm{ln} /, \mathrm{e} / \mathrm{l}, / \mathrm{l} /$. Kata tersebut pada bahasa Morela dan Mamala mengalami korespondensi fonemis di akhir kata menjadi heney yang terdiri atas susunan /h/, /e/, /n/, /e/, /n/. Korespondensi yang terjadi, yaitu /l/ pada kata henel berkorespondensi dengan / $/ \mathrm{y} /$ pada kata heney.

\section{Kemiripan secara Fonetis}

Bila tidak dapat dibuktikan bahwa sebuah pasangan kata dalam kedua bahasa itu mengandung korespondensi fonemis, tetapi pasangan kata itu ternyata mengandung kemiripan secara fonetis dalam posisi artikulatoris yang sama, pasangan itu dapat dianggap sebagai kata kerabat. Yang dimaksud dengan mirip secara fonetis adalah ciri-ciri fanetisnya harus cukup serupa sehingga dapat dianggap sebagai alofon.Berikut pasangan kata pada bahasa Hitu, Wakal, Morela, Mamala, dan Hila yang memiliki kemiripan secara fonetis. 
Tabel 4

Pasangan Kata yang Mirip secara Fonetis

\begin{tabular}{|c|c|c|c|c|c|}
\hline Gloss & Hitu & Wakal & Morela & Mamala & Hila \\
\hline angin & anin & anin & anin & anin & Anin \\
\hline itu & na & ma & ya & ma & Ma \\
\hline lempar & keri & teri & keri & keri & Keri \\
\hline bintang & ma:lin & bintan & ma:rin & ma:rin & Malin \\
\hline bapak & baba & papa?u & baba & baba & Papa \\
\hline
\end{tabular}

Pada tabel 4 pasangan kata yang mirip secara fonetis dapat dilihat pada kata angin. Kata tersebut dalam bahasa Hitu dan Wakal memiliki bentuk yang sama, yaitu anin yang terdiri atas susunan /a/, /n/, /i/, /n/. Bentuk lain yang sama terdapat pula pada bahasa Morela, Mamala, dan Hila, yaitu aniy yang terdiri atas susunan $/ a /, / n /, / i /, / y /$. Antara bentuk anin dan aniy memiliki perbedaan bentuk fonem di akhir kata, yaitu /n/ dan /y/. Meskipun demikian kedua kata ini masih dikategorikan kerabat karena kedua fonem yang berbeda tersebut berada pada posisi cara artikulasi yang sama, yaitu nasal.

Kata selanjutnya pada tabel 4 yang mirip secara fonetis dapat dilihat pada kataitu. Kata tersebutpada bahasa Hitu memiliki na yang terdiri atas susunan /n/, /a/. Pada bahasa Morela memiliki bentuk $\eta a$ yang terdiri atas susunan $/ \mathrm{y} /$, /a/. Sementara itu, pada bahasa Wakal, Mamala, dan Hila memiliki bentuk yang sama, yaituma yang terdiri atas susunan /m/, /a/. Ketiga bentuk tersebut memiliki fonem awal yang berbeda, yaitu $/ \mathrm{y} /$, /y/, dan /m/. Meskipun demikian katana,ya, dan ma masih berkerabat karena ketiga fonem yang berbeda tersebut berada pada posisi cara artikulasi yang sama, yaitu nasal.

Kata berikutnya yang mirip secara fonetis pada tabel 4 adalah kata lempar. Kata ini dalam bahasa Hitu, Morela, Mamala, dan Hila memiliki bentuk yang sama, yaitu keri yang terdiri atas susunan fonem $/ \mathrm{k} / \mathrm{l} / \mathrm{e} /, \mathrm{r} / \mathrm{r}$, /i/. Sedangkan pada bahasa Wakal memiliki bentuk teri yang terdiri atas susunan $/ \mathrm{t} / \mathrm{l} / \mathrm{e} /$, /r/, /i/. Di awal kata, bentuk keri dan teri memiliki bentuk fonem yang berbeda, yaitu /k/ dan /t/. Meskipun fonem awal kedua kata itu berbeda, namun kedua kata tersebut masih dikategorikan kerabat karena fonem /k/ dan /t/ masih berada pada posisi cara artikulasi yang sama, yaitu hambat (letup).

Selanjutnya pada tabel 4, kata yang mirip secara fonetis adalah kata bintang. Kata ini pada bahasa Morela dan Mamala memiliki bentuk yang sama, yaitu ma:riy yang terdiri atas susunan fonem $/ \mathrm{m} /, / \mathrm{a} /, / \mathrm{r} /$, /i/, /y/. Pada bahasa Hitu memiliki bentuk ma:linyang terdiri atas susunan $/ \mathrm{m} /, \mathrm{a} /, / \mathrm{l} /$, /i/, /n/, bahasa Hila memiliki bentuk malig yang terdiri atas susunan $/ \mathrm{m} /, / \mathrm{a} /, / 1 /, / \mathrm{i} /, / \mathrm{y} /$. Kata ma:riy, ma:lin, dan maliy memiliki bentuk fonem yang berbeda di tengah kata, yaitu /r/ dan /1/. Meskipun fonem tengah ketiga kata tersebut berbeda, namun ketiga kata itu masih berkerabat karena /r/ dan /1/ berada pada tempat artikulasi yang sama, yakni apikoalveolar.

Pada tabel 4kata selanjutnya yang mirip secara fonetis adalah kata bapak. Kata tersebutmemiliki persamaan fonem di tiga bahasa, yaitu bahasa Hitu, Morela, dan Mamala, yakni kata baba yang terdiri atas susunan /b/, /a/, /b/, /a/. Sementara itu, pada bahasa Wakal memiliki bentukpapa?uyang terdiri atas susunan /p/, /a/, /p/, /a/, /?/, /u/dan bahasa Hila memiliki bentukpapa yang terdiri atas susunan /p/, /a/, /p/, /a/. Kata baba, papa?u, dan papa memiliki fonem yang berbeda di awal kata, yaitu /b/ dan $/ \mathrm{p} /$. Meskipun fonem awal ketiga kata tersebut berbeda, namun ketiganya masih dikategorikan kerabat karena /b/ dan /p/ 
masih berada pada tempat artikulasi yang sama, yakni bilabial.

\section{Satu Fonem Berbeda}

Bila dalam satu pasangan kata terdapat perbedaan satu fonem, tetapi perbedaan itu dapat dijelaskan terjadi karena pengaruh lingkungan yang dimasukinya, sedangkan dalam bahasa lain pengaruh lingkungan itu tidak mengubah fonemnya maka pasangan kata tersebut dapat ditetapkan sebagai kata kerabat. Berikut pasangan kata pada bahasa Hitu, Wakal, Morela, Mamala, dan Hila yang satu fonemnya berbeda.

Tabel 5

Pasangan Kata yang Satu Fonemnya Berbeda

\begin{tabular}{|c|c|c|c|c|c|}
\hline Gloss & Hitu & Wakal & Morela & Mamala & Hila \\
\hline Berat & mahe:la & mahela & yahela & mahela & Mahela \\
\hline Besar & ne:la & nela & ne:la & ne:la & ne:la \\
\hline Hujan & $\mathrm{u}$ :lan & $\mathrm{u}: \operatorname{lan}$ & u:lay & u:lay & $\mathrm{u}$ :lay \\
\hline telinga & tari:na & tali:nai & tari:na & tari:na & tari:na \\
\hline Lain & sahan & sahan & sahay & sahay & Laen \\
\hline
\end{tabular}

Kata pada tabel 5 yang satu fonemnya berbeda dapat dilihat pada kata berat. Kata ini memiliki bentuk yang sama pada bahasa Hitu, Wakal, Mamala, dan Hila, yaitu mahela yang terdiri atas susunan $/ \mathrm{m} /, / \mathrm{a} /, \mathrm{h} /$, /e/, /l/, /a/. Sementara itu, kata berat pada bahasa Morela memiliki bentuk yahela yang terdiri atas susunan //y/, /a/, /h/, /e/, /l/, /a/. Kata mahela dan yahela memiliki satu fonem yang berbeda di awal kata, yaitu $/ \mathrm{m} /$ pada kata mehela dan / $\mathrm{y} /$ pada kata yahela.

Pasangan kata berikutnya pada tabel 5 yang satu fonemnya berbeda adalah kata besar. Kata ini memiliki bentuk yang sama pada bahasa Hitu, Morela, Mamala, dan Hila, yaitu ne:la yang terdiri atas susunan $/ \mathrm{n} /$, /e/, /1/, /a/. Sementara itu, pada bahasa Wakal memiliki bentuk nela yang terdiri atas susunan /n/, /e/, /l/, /a/. Kedua kata tersebut memiliki satu fonem yang berbeda di awal kata, yaitu /n/ pada kata nela dan /n/ pada kata nela.

Selanjutnya kata yang satu fonemnya berbeda pada tabel 5, yaitu kata hujan. Kata ini pada bahasa Hitu dan Wakal memiliki bentuk yang sama, yaitu $u$ :lan yang terdiri atas susunan /u/, /l/, /a/, /n/. Sementara itu, pada bahasa Morela, Mamala, dan Hila memiliki bentuk u:lay yang terdiri atas susunan u/, /l/, /a/, /y/. Kedua kata tersebut memiliki satu fonem yang berbeda di akhir kata, yaitu fonem /n/ pada kata $u$ :landan /n/ pada kata $u: l a \eta$.

Kata lainnya yang satu fonemnya berbeda pada tabel 5 adalah kata telinga. Kata ini pada bahasa Hitu, Morela, Mamala, dan Hila memiliki bentuk yang sama, yaitu tari:na yang terdiri atas susunan /t/, /a/, /r/, /i/, /n/, /a/. Sementara itu, pada bahasa Wakal memiliki bentuk ta:linai yang terdiri atas susunan /t/, /a/, /l/, /i/, /n/, /a/, /i/. Kedua kata tersebut memiliki satu fonem yang berbeda di tengah kata, yaitu /r/ pada kata tarina dan /1/ pada kata talinai.

Kata berikutnya pada tabel 5 yang satu fonemnya berbeda adalah kata lain. Kata ini pada bahasa Hitu dan Wakal memiliki bentuk yang sama, yaitu sahan yang terdiri atas susunan /s/, /a/, /h/, /a/, /n/. Sementara itu, bentuk yang sama pula ditunjukkan pada bahasa Morela dan Mamala, yaitu sahay yang terdiri atas susunan /s/, /a/, /h/, /a/, /y/ sedangkan bentuk yang berbeda terdapat pada bahasa Hila, yaitu laen yang terdiri atas susunan /l/, /a/, e/, /y/. Kata sahan pada bahasa Hitu dan Wakal memiliki satu fonem yang berbeda di akhir kata dengan kata sahay pada bahasa Morela dan Mamala, yaitu $/ \mathrm{n} /$ dan $/ \mathrm{y} /$. 


\section{Pelesapan Fonem}

Berikut pasangan kata pada bahasa Hitu, Wakal, Morela, Mamala, dan Hila yang mengalami pelesapan fonem.

Tabel 6

Pasangan Kata yang Mengalami Pelesapan Fonem

\begin{tabular}{|c|c|c|c|c|c|}
\hline Gloss & Hitu & Wakal & Morela & Mamala & Hila \\
\hline $\mathrm{aku}$ & yau & iyau & $\mathrm{au}$ & $\mathrm{au}$ & Yau \\
\hline (ber-) kelahi & pahiya & pahiya & ahiya & pahiya & Pahiya \\
\hline cium (bau) & pahanisu & pani:su? & panesu?i & pahanisu & Pahanisu \\
\hline gigi & ni:ki & nikin & ni:ki & ni:ki & Nikin \\
\hline main & pahai & pahai & pahaen & ahai & Pahai \\
\hline
\end{tabular}

Berdasarkan pada tabel 6pelesapan fonem tampak pada kata $a k u$. Kata tersebut dalam bahasa Hitu dan Hila memiliki bentuk yang sama yaitu yau yang terdiri atas susunan /y/, /a/, /u/. Sedangkan pada bahasa Wakal mendapat penambahan /i/ di awal kata sehingga menjadi iyau yang terdiri atas susunan /i/, /y/, /a/, /u/. Kata yau dan iyau yang mengalami pelesapan fonem pada bahasa Morela dan Mamala adalah /y/ dan /i/ sehingga kata tersebut menjadi au yang terdiri atas susunan /a/, /u/.

Kata lainnya yang mengalami pelesapan fonem pada tabel 6 adalah (ber-) kelahi. Kata tersebut pada bahasa Hitu, Wakal, Mamala, dan Hila memiliki bentuk yang sama, yaitu pahiya yang terdiri atas susunan /p/, /a/, /h/, /i/, /y/, /a/. Pada bahasa Morela kata ini mengalami pelesapan fonem di awal kata, yaitu /p/ sehingga menjadi ahiya yang terdiri atas susunan /a/, /h/, /i/, /y/, /a/.

Kata selanjutnya yang mengalami pelesapan fonem pada tabel 6 adalah cium (bau). Kata tersebut memiliki bentuk yang sama pada bahasa Hitu, Mamala, dan hila yaitu pahanisu yang terdiri atas susunan $/ \mathrm{p} /$, /a/, /h/, /a/, /n/, /i/, /s/, /u/. Pada bahasa Wakal dan Morela kata pahanisu mengalami pelesapan fonem di tengah kata, yaitu $/ \mathrm{h} /$ dan /a/ sehingga pada bahasa Wakal menjadi pani:su? yang terdiri atas /p/, /a/, /n/, /i/, /s/, /u/. Pada bahasa Morela selain mengalami pelesapan fonem, terdapat pula perubahan fonem di tengah kata, yaitu /i/ menjadi /e/ dan terdapat penambahan /i/ di akhir kata sehingga menjadi panesu?i yang terdiri atas susunan /p/, /a/, /n/, /e/, /s/, /u/, /i/.

Selanjutnya, kata yang mengalami pelesapan fonem adalah kata gigi. Kata ini pada bahasa Wakal dan Hila memiliki bentuk yang sama, yaitu nikiø yang terdiri atas susunan fonem /n/, /i/, /k/, /i/, /n/. Pada bahasa Hitu, Morela, dan Mamala kata nikin mengalami pelesepan $/ \mathrm{y} /$ pada akhir kata sehingga menjadi ni:ki yang terdiri atas susunan /n/, /i/, /k/, /i/.

Kata lainnya yang mengalami pelesapan fonem adalah main. Kata ini pada bahasa Hitu, Wakal, dan Hila memiliki bentuk yang sama, yaitu pahai yang terdiri atas susunan fonem $/ \mathrm{p} /, / \mathrm{a} /, / \mathrm{h} /, / \mathrm{a} /, / \mathrm{i} /$. Sementara itu, pada bahasa Morela berbentuk pahaey yang terdiri atas susunan /p/, /a/, /h/, /a/, /e/, /y/. Pada bahasa Mamala, kata pahai dan pahaeymengalami pelesapan /p/ di awal kata sehingga menjadi ahai yang terdiri atas susunan /a/, /h/, /a/, /i/.

Berdasarkan kriteria penentuan kata kerabat/ cognate yang telah dipaparkan dan dengan menggunakan rumus penghitungan leksikostatistik maka persentase kekerabatan bahasa Hitu, Wakal, Morela, Mamala, dan Hila dapat dilihat pada tabel berikut ini. 
Tabel 7

Matriks Persentase Kekerabatan Bahasa

\begin{tabular}{|c|c|c|c|c|c|}
\hline$\%$ & Hitu & Wakal & Morela & Mamala & Hila \\
\hline Hitu & - & & & & \\
\hline Wakal & 84 & - & & & \\
\hline Morela & 81 & 77 & - & & \\
\hline Mamala & 87,5 & 82,5 & 86,5 & - & \\
\hline Hila & 90 & 82 & 78,5 & 84 & - \\
\hline
\end{tabular}

Di lihat dari tabel 7 di atas maka dapat diketahui bahwa terdapat sepuluh pasangan bahasa dengan tingkat persentase kekerabatan yang berbeda-beda. Kesepuluh pasangan bahasa tersebut adalah bahasa (1) Hitu-Wakal denganpersentase kekerabatan sebesar 84\%, (2) Hitu-Morela sebesar 81\%, (3) Hitu-Mamala sebesar 87\%, (4) Hitu-Hila sebesar 90\%, (5) Wakal-Morela sebesar 77\%, (6) Wakal-Mamala sebesar 82,5\%, (7) Wakal-Hila sebesar 82\%, (8) MorelaMamala sebesar 86,5\%, (9) Morela-Hila sebesar 78,5\% dan (10) Mamala-Hila sebesar $84 \%$.

Berdasarkan penjabaran di atas, tingkat kekerabatan kesepuluh pasangan bahasa tersebut dapat diurutkan dari tingkat persentase terbesar hingga yang terkecil. Untuk lebih jelasnya, urutan tingkat persentase kekerabatan kesepuluh pasangan kata tersebut dapat dilihat pada grafik persentase kekerabatan berikut ini.

\section{Grafik 1 \\ Persentase Bahasa Kerabat}
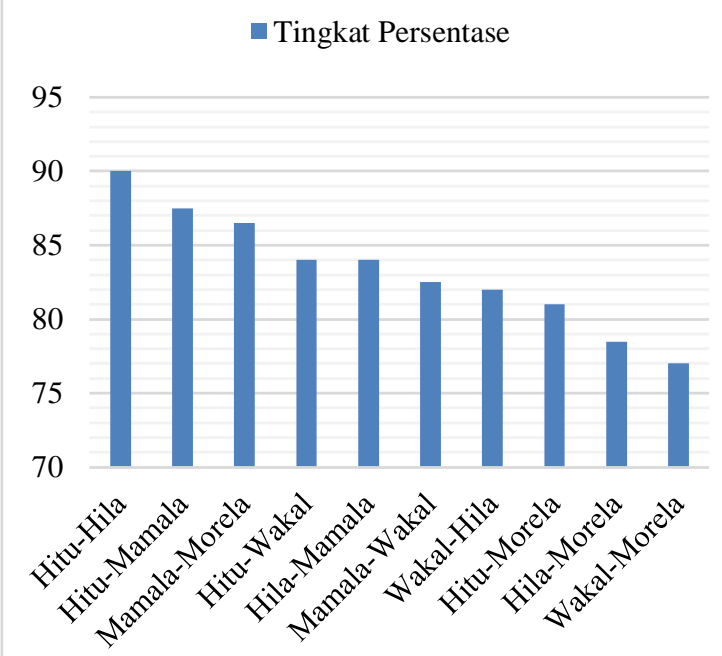

Dari grafik di atas, terlihat bahwa tingkat kekerabatan paling dekat hingga jauh berturut-turut adalah bahasa Hitu-Hila dengan persentase kekerabatan sebesar 90\%, disusul kekerabatan bahasa Hitu-Mamala dengan persentase $87,5 \%$. Tingkat kekerabatan selanjutnya adalah bahasa Mamala-Morela 86,5\%, bahasa Hitu-Wakal dan Hila-Mamala dengan persentase yang sama, yaitu $84 \%$, bahasa Mamala-wakal $82,5 \%$, bahasa Wakal-Hila $82 \%$, bahasa Hitu-Morela $81 \%$, bahasa Hila-Morela $78,5 \%$, dan bahasa dengan tingkat persentase terendah berdasarkan tabel 5 di atas adalah bahasa Wakal-Morela dengan persentase kekerabatan sebesar $77 \%$.

Dari penjabaran di atas dan mengacu pada teori yang dikemukakan oleh Crowley (2010), relasi genetis antara bahasa Hitu, Wakal, Morela, Mamala, dan Hila dapat ditentukan, yaitu antara bahasa Hitu-Hila, Hitu-Mamala, Mamala-Morela, Hitu-Wakal, Hila-Mamala, Mamala-Wakala, Wakal-Hila, dan Hitu-Morela dapat dikategorikan sebagai satu bahasa dialek, karena berada pada posisi $81 \%$ ke atas. Sementara itu, bahasa Hila-Morela dan Wakal-Morela dapat dikategorikan sebagai subkeluarga bahasa karena berada pada posisi $61-81 \%$.

\section{PENUTUP}

Dari hasil uraian dan analisis kriteria kekerabatan, dapat disimpulkan bahwa kekerabatan bahasa Hitu, Wakal, Morela, Mamala, dan Hila dapat ditinjau berdasarkanempat cara, yaitu (1) kata yang identik atau sama, yaitu kata-kata yang dari bentuk dan susunan fonem-fonemnya sama; 
(2) korespondensi fonemis, yaitu saling bertukarnya fonem-fonem tertentu dalam hal ini /b/-/p/, /y/-/wa/, /k/-/t/, /s/-/y/, dan /l/$/ \mathrm{y} / ;(3)$ kemiripan secara fonetis, yaitu fonem-fonem yang berada pada posisi artikulatoris yang sama, yakni $/ \mathrm{n} /-/ \mathrm{n} /, / \mathrm{n} /-/ \mathrm{n} /-$ $/ \mathrm{m} /$ pada posisi nasal, /k/-/t/ pada posisi hambat (letup), /r/-/l/ pada tempat artikulasi apikoalveolar, /b/-/p/ pada tempat artikulasi bilabial; (4) satu fonem beda, yaitu pasangan kata yang hanya satu fonemnya berbeda, yakni $/ \mathrm{m} /-/ \mathrm{y} /, \quad / \mathrm{n} /-/ \mathrm{n} /, \quad / \mathrm{n} /-/ \mathrm{y} /, \quad / \mathrm{r} /-/ \mathrm{l} / ;$ (5) pelesapan fonem, yaitu ada fonem-fonem tertentu yang mengalami pelesapan di awal kata, yakni /y/, /i/, /p/, pelesapan di tengah kata, yakni $/ \mathrm{h} /$, /a/, dan pelesapan di akhir kata, yakni $/ \mathrm{y} /$.

Selanjutnya dari hasil perhitungan persentase kata kerabat dengan menggunakan rumus leksikostatistik, dapat disimpulkan bahwadari keseluruhan bahasa yang dianalisis, persentase kekerabatan bahasa yang terbesar berada pada bahasa Hitu-Hila dengan persentase kekerabatan sebesar 90\%. Berdasarkan persentase ini, bahasa Hitu-Hila dikategorikan sebagai satu bahasa dialek. Sementara itu, bahasa dengan tingkat persentase terendah adalah bahasa Wakal-Morela dengan tingkat persentase sebesar $77 \%$. Berdasarkan persentase ini, bahasa Wakal-Morela dikategorikan sebagai subkeluarga bahasa.

\section{DAFTAR PUSTAKA}

Alijah, Sitti. 2016. "Kekerabatan Bahasa Bugis dan Muna" Jurnal Humanika. No.16, Vol. 1. Semarang: Fakultas Ilmu Budaya Universitas Diponegoro

Anonim. 2011. Undang-Undang Dasar Republik Indoneesia Nomor 24 Tahun 2009 tentang Bendera, Bahasa, dan Lambang Negara, serta Lagu Kebansaan. Jakarta: Badan Pengembangan dan Pembinaan Bahasa Kementrian Pendidikan dan Kebudayaan.
Crowley, Terry. 2010. An Introduction to Historical Linguistics. Auckland: Oxford University Press.

Johnson, Keith. 2008. Quantitative Methods in Linguistics. Malden: Blackwell Publishing.

Keraf, Gorys. 1996. Linguistik Bandingan Historis. Jakarta: Gramedia Pustaka Utama.

2004. Komposisi: Sebuah Pengatar Kemahiran Berbahasa. Flores: Nusa Indah

Kridalaksana, Harimurti. 2008. Kamus Linguistik. Edisi Keempat. Jakarta: PT Gramedia Pustaka Utama.

Langgole, Nurdin. 1996. Leksikostatistik dai Dialektometri. Makalah Pada Temu Ilmiah dan Dialog Alumni Fakultas Sastra Unhas.

Nothofer, Bernd. 1990. “Tinjauan Sinkronis danDiakronis Dialek-Dialek Bahasa Jawadi Jawa Barat dan Jawa Tengah (BagianBarat)". Tulisan Ceramah dan Diskusioleh Pusat Studi BahasaBahasa Asia Tenggara-Pasifik. Yogyakarta: FakultasSastra UGM.

Simon, Johana Grace,dkk. 2015. "Kekerabatan Bahasa Alune dan Bahasa Wemale(Kajian Linguistik Historis Komparatif)". Jurnal Kajian Linguistik. Tahun II, No. 3. Manado: Universitas Samratulangi.

Sudarno, M. Ed. 1994. Perbandingan Bahasa Nusantara. Jakarta: Arikha Medika Cipta.

Sulistyono, Yunus dan Inyo Yos Fernandez. 2015. "Penerapan Teknik Leksikostatistik dalam Studi Komparatif Bahasa Barunusa, Kedang, dan Lamaholot di Nusa Tenggara Timur. Jurnal Pendidikan Humaniora. Vol. 16, No. 1. Malang: Universitas Negeri Malang.

Surbakti, Ernawati Br. 2014. Kekerabatan Bahasa Karo, Minang, dan Melayu: Kajian Linguitik Historis Komparatif. Jurnal Politeknik Negeri Lhokseumawe. Vol. 2, No. 1. 
Lhokseumawe: Politeknik Negeri Lhokseumawe.

Taufik. 2017."Deiksis Persona Bahasa Indonesia dialek Ambon". Jurnal Totobuang. Vol. 5, No. 2. Ambon: Kantor Bahasa Maluku.

Trask, R.L. 2000. The Dictionary of Historical and Comparative
Lnguistics. Edinburg: Edinburg University Press.

Wacana, Gitit I.P. 2013. "Relasi Kekerabatan Bahasa-Bahasa di Kabupaten Poso". Jurnal Kependidikan. Vol. 6, No.1. Poso: Universitas Sintuwu Maroso Poso. 